Romantic Reconfigurations: Studifes in Literature and Cenlsmie 1780-1850

\title{
Women's Literary \\ Networks and \\ Romanticism
}

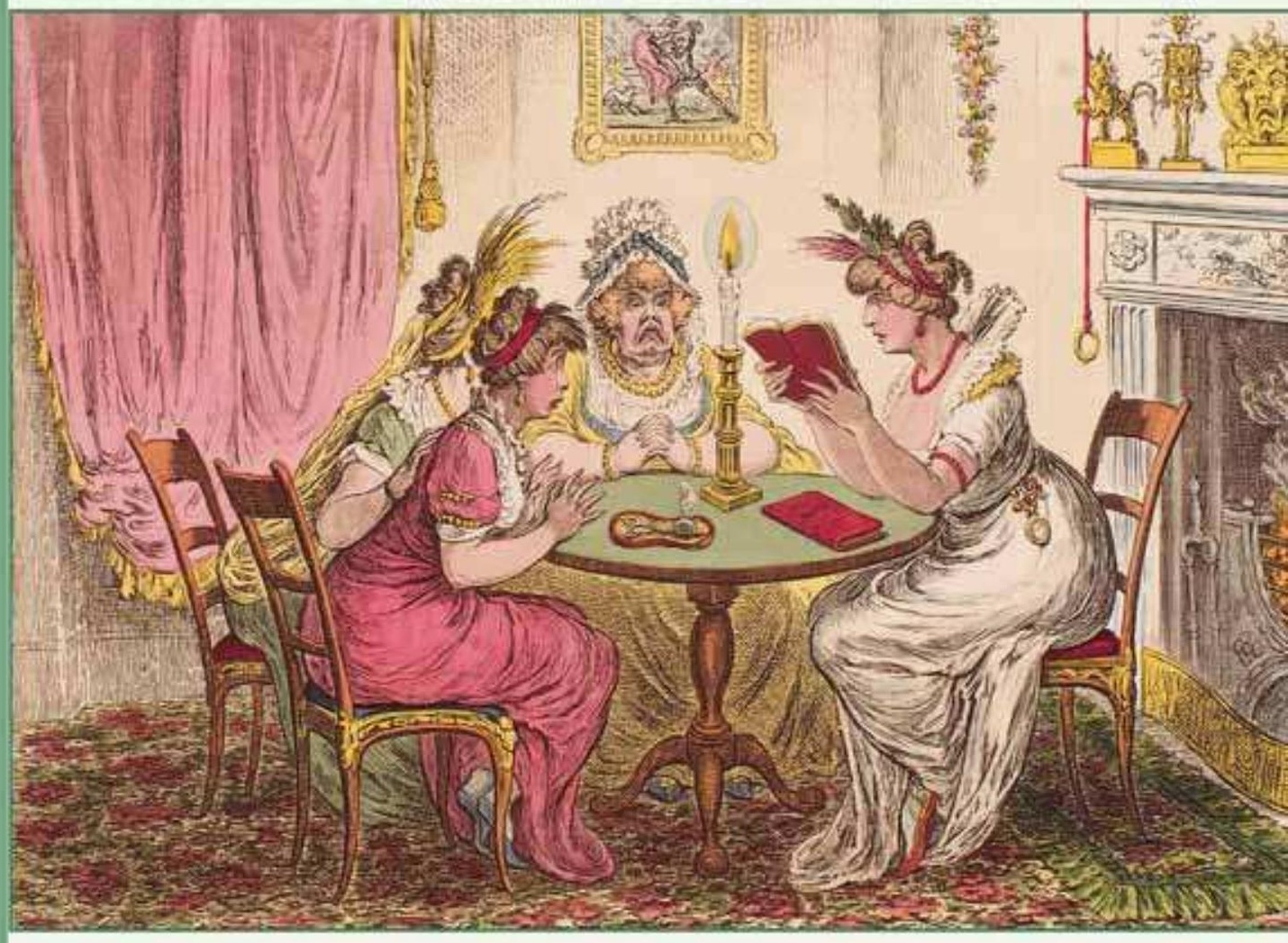

"A Tribe of Authoresses"

BDITE BY ANDREW O. WINCKLES \& ANGELA REHBEIN 


\title{
Romantic Reconfigurations: \\ Studies in Literature and Culture 1780-1850
}

\author{
Series Editors: \\ Professor Tim Fulford, De Montfort University \\ Professor Alan Vardy, Hunter College and the Graduate Center, CUNY
}

As befits a series published in the city of Roscoe and Rushden, a city that linked Britain to the transatlantic trade in cotton, in sugar, and in people, Romantic Reconfigurations reconfigures the literary and cultural geographies and histories of Romanticism. Topics featured include, but are by no means confined to, provincial and labouring-class writing, diasporic and colonial writing, natural history and other scientific discourse, journalism, popular culture, music and theatre, landscape and nature, cosmopolitanism and travel, poetics and form. 


\title{
Women's Literary Networks and Romanticism
}

\section{"A Tribe of Authoresses"}

\author{
Edited by: \\ Andrew O. Winckles and Angela Rehbein
}




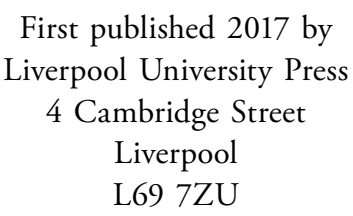

Copyright (C) 2017 Liverpool University Press

The right of Andrew O. Winckles and Angela Rehbein to be identified as the editors of this book have been asserted by them in accordance with the Copyright, Designs and Patents Act 1988.

All rights reserved. No part of this book may be reproduced, stored in a retrieval system, or transmitted, in any form or by any means, electronic, mechanical, photocopying, recording, or otherwise, without the prior written permission of the publisher.

British Library Cataloguing-in-Publication data

A British Library CIP record is available print ISBN 978-1-78694-060-5 cased epdf ISBN 978-1-78694-832-8

Typeset by Carnegie Book Production, Lancaster 


\section{Contents}

Acknowledgements vii

Notes on the Contributors $\quad$ ix

1 Introduction: "A Tribe of Authoresses" 1

Andrew O. Winckles and Angela Rebbein

2 Sisters of the Quill: Sally Wesley, the Evangelical Bluestockings, and the Regulation of Enthusiasm

Andrew O. Winckles

3 Susanna Watts and Elizabeth Heyrick: Collaborative

Campaigning in the Midlands, 1820-34

Felicity James and Rebecca Shuttleworth

4 Ageing, Authorship, and Female Networks in the Life Writing of Mary Berry (1763-1852) and Joanna Baillie (1762-1851)

Amy Culley

5 The Female Authors of Cadell and Davies

Michelle Levy and Reese Irwin

6 Modelling Mary Russell Mitford's Networks: The Digital Mitford as Collaborative Database

Elisa Beshero-Bondar and Kellie Donovan-Condron 
Women's Literary Networks and Romanticism

7 The Citational Network of Tighe, Porter, Barbauld, Lefanu, Morgan, and Hemans

Harriet Kramer Linkin

8 Edgeworth's Letters for Literary Ladies: Publication Peers and Analytical Antagonists

Robin Runia

9 Mary Shelley and Sade's Global Network

Rebecca Nesvet

10 'Your Fourier's Failed': Networks of Affect and Anti-Socialist Meaning in Aurora Leigh

Eric Hood

Afterword

Index 


\section{Acknowledgements}

We would first like to thank Stephen C. Behrendt for inviting us to participate in the National Endowment for the Humanities 2013 Summer Seminar on 'Reassessing British Romanticism', and for his unparalleled generosity and support as we saw this volume through from inception to completion. Were it not for the scholarly network forged at this seminar, this volume would not exist. We would also like to thank the other seminar members for the vigorous and challenging conversations that helped crystallize our interests in Romantic women's voices. Thank you to Alan Vardy and Tim Fulford for inviting us to be a part of this exciting new series and for helping us refine our project, and thank you to Jenny Howard at Liverpool University Press for shepherding us through the production process. To all of our contributors, thank you for trusting us with your work and for making the process of assembling this volume so enjoyable. 



\section{Notes on the Contributors}

Elisa Beshero-Bondar is Associate Professor of English at the University of Pittsburgh at Greensburg. Her book, Women, Epic, and Transition in British Romanticism, was published by the University of Delaware Press in 2011. Her published articles in ELH (English Literary History), Genre, Philological Quarterly, and The Wordsworth Circle investigate the poetry of Robert Southey, Mary Russell Mitford, and Lord Byron. She is the architect of the Digital Mitford Project and other web-based digital humanities projects, and is working in conjunction with MITH's Shelley-Godwin Archive, Romantic Circles, and Pittsburgh-based research team on collating the print and manuscript versions of Frankenstein in time for its bicentennial in 2018. She was elected in 2015 to serve on the TEI Technical Council, an eleven-member international committee that supervises amendments to the TEI Guidelines.

Amy Culley is Senior Lecturer in English at the University of Lincoln, UK. She is the author of British Women's Life Writing, 1760-1840: Friendship, Community, and Collaboration (Palgrave, 2014), co-editor with Anna Fitzer of Editing Women's Writing, 1670-1840 (Routledge, 2017), co-editor with Daniel Cook of Women's Life Writing, 1700-1850: Gender, Genre and Authorship (Palgrave, 2012), and editor of Women's Court and Society Memoirs, volumes 1-4 (Pickering \& Chatto, 2009). She is currently researching narratives of ageing and old age in women's life writing of the early nineteenth century.

Kellie Donovan-Condron is a founding editor and Poetry section editor for the Digital Mitford Archive, a digital humanities project that is putting the poetry, historical drama, short prose sketches, and voluminous correspondence of nineteenth-century writer Mary Russell Mitford online. She 
teaches intermediate literature, rhetoric, and foundation courses in the Arts and Humanities at Babson College outside Boston, MA. Her research interests are an interdisciplinary mix of literature, history, and material culture. Areas of particular interest include urban identity in the early nineteenth century, the gothic novel, women's writing, consumerism and consumption in literature, Southern Gothic, and fairy tales. In the summer of 2013, she was selected to be a summer scholar in the National Endowment for the Humanities seminar 'Reassessing British Romanticism'.

Eric Hood is an Assistant Professor at Adrian College and holds a $\mathrm{PhD}$ in English from the University of Kansas. He is a founding editor at The Digital Mitford. His scholarship focuses on British epic performances during the eighteenth and nineteenth century and cultural theory.

Reese Irwin is a graduate student in English at Simon Fraser University. Her interests lie in Romantic era literature, women's writing, the digital humanities, and print and manuscript culture. She is a research assistant on Dr. Michelle Levy's Women's Print History Project, 1750-1836, a bibliography encompassing women in print in the Romantic period. Her Master's project, Compiling Sanditon, analyzes the trajectory of Jane Austen's Sanditon from private, unfinished manuscript (as it was left upon Austen's death in 1817), to its fragmentary and then complete publication in the early twentieth century.

Felicity James is Associate Professor in eighteenth and nineteenth-century English literature at the University of Leicester, with research interests in Romantic friendship, sociability, and religious dissent. With postgraduate student Rebecca Shuttleworth, she is working on a project to recover and commemorate the lives and networks of Leicester abolitionists and campaigners Elizabeth Heyrick and Susanna Watts.

Harriet Kramer Linkin is an Emerita Distinguished Professor of English at New Mexico State University, where she teaches courses in British Romanticism and women's literature. She has published widely on Romantic-era writers (particularly William Blake and Mary Tighe) and is the editor of the first edition of Mary Tighe's Verses Transcribed for H.T. (Romantic Circles, 2014), the first edition of Mary Tighe's Selena: A Scholarly Edition (Ashgate, 2012), the first scholarly edition of The Collected Poems and Journals of Mary Tighe (UP Kentucky, 2005), and the co-editor (with Stephen C. Behrendt) of two collections on Romantic women poets: Romanticism and Women Poets: Opening the Doors of Reception (UP Kentucky, 1999) and Approaches to Teaching Women Poets of the British Romantic Period (MLA, 1997). 
Michelle Levy is a Professor in the Department of English at Simon Fraser University. She works in the fields of Romantic literary history, print and manuscript culture, and women's book history. She is the co-editor of the Broadview Reader in Book History (with Tom Mole, 2014) and the co-author of Broadview Introduction to Book History (with Tom Mole, 2017). She has published extensively on women writers, digital humanities and pedagogy, and has recently completed a book on literary manuscripts and manuscript culture of the Romantic period. She directs the Women's Print History Project, 1750-1836, a comprehensive bibliographical database of women's books, and is working on a project that addresses the production and circulation of women's books during this period.

Rebecca Nesvet is Assistant Professor of English at the University of Wisconsin, Green Bay. She has published in journals including Essays in Romanticism, The Keats-Shelley Journal, North Wind: A Journal of George Macdonald Studies, and Women's Writing, as well as the Romantic Textualities pedagogy blog. Her TEI edition of Malcolm Rymer's 1820 play Science and Art, as published by his son James Malcolm Rymer, appears in the open-access Scholarly Editing: The Journal of the Association for Documentary Editing (2017). In 2012, she won the Lore Metzger Prize (best graduate essay) at the International Conference on Romanticism.

Angela Rehbein is Associate Professor of English at West Liberty University in West Virginia, where she teaches courses in composition, literary theory, British literature, and World literature. She has published articles in EighteenthCentury Fiction and Women's Writing, and in 2015 co-edited (with Andrew Winckles) a special issue of Women's Writing on 'Reassessing British Women Writers of the Romantic Period'. Her current research considers the connections between Romantic-era imperialist and domestic discourses, particularly as they coalesce in the figure of the mother.

Robin Runia is Associate Professor of English at Xavier University of Louisiana. She has published articles in Restoration and Eighteenth-Century Theater Research, Journal of Early Modern Cultural Studies, and Religion in the Age of Enlightenment. She is currently at work on a monograph project Displaced Britons: Africans and Creoles in the Work of Maria Edgeworth.

Rebecca Shuttleworth holds an AHRC-funded Collaborative Doctoral Award at the University of Leicester, and has worked closely with the Records Office for Leicestershire, Leicester, and Rutland to investigate archival resources relating to Elizabeth Heyrick and Susanna Watts, and to make them accessible to different communities through life-writing events and creative workshops. 
Andrew O. Winckles is Assistant Professor and Chair of Core (Interdisciplinary Studies) at Adrian College. His work on Methodist women's writing has been published in Eighteenth-Century Studies, Nineteenth-Century Studies, and other scholarly collections. He edited, with Angela Rehbein, a special issue of Women's Writing on 'Reassessing British Women Writers of the Romantic Period' (2015), and is currently completing a monograph titled EighteenthCentury Women's Writing and the Methodist Media Revolution: Consider the Lord as Ever Present Reader. 


\section{Introduction}

\section{"A Tribe of Authoresses"}

Andrew O. Winckles and Angela Rehbein

In April 1800, Charles Lamb wrote to Samuel Taylor Coleridge to apologize for a minor annoyance he and his sister Mary had caused the mercurial poet. The letter is included in Lamb's collected correspondence under the title 'With the Blue Stockings', and it signals both the significance of women's literary networks during the Romantic period and the competing discourses surrounding such networks and female authorship more generally:

You blame us for giving your direction to Miss Wesley; the woman has been ten times after us about it, and we gave it her at last, under the idea that no further harm would ensue, but she would once write to you, and you would bite your lips and forget to answer it, and so it would end. [...] Miss Wesley and her friend, and a tribe of authoresses that come after you daily, and, in defect of you, hive and cluster upon us, are the shadows. You encouraged that mopsey, Miss Wesley, to dance after you, in the hope of having her nonsense put into a nonsensical Anthology. We have pretty well shaken her off, by that simple expedient of referring her to you; but there are more burrs in the wind. I came home t'other day from business, hungry as a hunter, to dinner, with nothing, I am sure, of the author but hunger about me, and whom found I closeted with Mary but a friend of this Miss Wesley, one Miss Benje, or Benjey-I don't know how she spells her name. I just came in time enough, I believe, luckily to prevent them from exchanging vows of eternal friendship. It seems she is one of your authoresses, that you first foster, and then upbraid us with. ${ }^{1}$

${ }^{1}$ Charles Lamb and Mary Lamb, 'Charles Lamb to S. T. Coleridge', in The Works of Charles and Mary Lamb, ed. E. V. Lucas (London: Methuen, 1905), 6: p. 162. 
The 'Miss Wesley' Lamb references is Miss Sarah Wesley, better known as Sally, the daughter of Charles Wesley and Sarah Gwynne Wesley. Charles Wesley is perhaps best known as the younger brother of John Wesley, founder of Methodism, though Charles himself was instrumental in the foundation of the movement and served as its chief poet and hymnist. Like her father, Sally Wesley was a gifted poet, though few of her poems saw print, and she had several anonymous essays published in The Monthly Magazine. 'Miss Benje' is Elizabeth Benger, who would go on to become a noted historian - penning histories of Ann Boleyn, Mary Queen of Scots, and Elizabeth Stuart - and a close friend of the novelist Elizabeth Hamilton, whose memoirs she would later publish. Both Wesley and Benger were well known in London literary circles at this time: Wesley because of her famous last name and her association with Dr. George Gregory, Benger because of her connections with important literary women like Hamilton and the Porter sisters. Their status makes the condescending tone of Lamb's letter to Coleridge quite striking. The implication is that such 'minor' literary women are beneath the notice of great men like Lamb and Coleridge - their intellectual and literary aspirations a mere annoyance to be batted aside. The fact that Lamb is relieved to have interrupted Mary and Benger before they could exchange 'vows of eternal friendship' subtly indicates the disruptive power of such connections. Furthermore, Lamb's characterization of this network of women as a 'tribe' of authoresses is interesting for its orientalist and colonialist implications: the term 'tribe' transforms such women into vaguely threatening 'others' who violate cultural norms.

Despite recent gains in our awareness of the importance of networks and networking during the Romantic period, we still lack a complex understanding of how such 'tribe[s] of authoresses' functioned for women like Benger and Wesley. Indeed, we lack a complex understanding of what we mean by the term 'network' to begin with, both historically and critically. As Lindsay O'Neill points out in her work on the uses of the letter at the turn of the eighteenth century, the term network 'remains messy and vague. Historians rarely interrogate its meaning, which has disguised the networking practices of the British during the late seventeenth century and early eighteenth centuries'; thus, 'digging into the vagueness of the term and tracing how historians have employed it pushes to the surface a vast constellation of networks of different sizes, shapes, and purposes.. ${ }^{2}$ Our project in this volume is to explicate the types of 'networking practices' that O'Neill describes, which were local, familial, international, and professional. They were organized around a variety of beliefs, ideas, or interests, and some smaller networks were encompassed within larger networks. In other words, these networks were not static but, as

${ }^{2}$ Lindsay O'Neill, The Opened Letter: Networking in the Early Modern British World (Philadelphia: University of Pennsylvania Press, 2014), p. 4. 
O'Neill points out, 'active and changeable organisms' (p. 7), which have yet to be fully mapped or interrogated. These, then, are the questions that guide this collection: What were Romantic-era networks, and what can their scope and nature tell us about who had access to literary culture in this period? In what form(s) did material move through literary networks? How did social and gendered protocols structure literary networks - and, in turn, how did these networks influence the larger literary culture?

Part of the difficulty in approaching these questions derives from the fact that our tendency toward comparisons between eighteenth- and nineteenthcentury 'social' networking and twenty-first century digital networks has the potential to elide what was actually happening during the period, especially among women. Women created and used networks in different ways and for different purposes than are common today - differences that were often organized by the technologies and means of mediation that were available to them. By re-reading and re-thinking the purposes of manuscript culture, re-examining the role of women in Romantic-era printing, tracing local networks of affiliation and interest, and employing digital tools to collect 'big data', the essays in this collection provide a more nuanced picture of what women's literary networks actually looked like, how they functioned, and how they structured Romantic-era literary production. What all of these essays have in common is an understanding that not only did Romantic-era writing not happen in a vacuum, but also that there were many different modes and means of literary expression open to women writers during the period. Applying a variety of critical and disciplinary methods to our study of women's literary networks thus allows us to interrogate key assumptions about the literary culture of the eighteenth century in general and the Romantic period in particular; specifically, the assumption that this period marked the rise of the author as individual, as well as the creation of the category of 'literature' itself.

While studies of women's writing during the Romantic period have long since moved beyond Virginia Woolf's claim in A Room of One's Own that, for much of literary history, women lacked access to the means of literary production, we have not necessarily, or at least not consistently, gone beyond this assumption to examine how the networks of intimacy engendered by female correspondence created the climate for literary work well beyond the printed page. As the essays in this volume reveal, the ways that women used literary networks, in whatever form, also influenced the ways that they thought about their own identities and their identities in relation to others. Ultimately, what this volume tracks is how the protocols and norms that structured these literary networks were reflected in these women's lives and relationships specifically, and then more broadly in the literary culture of the period. We approach this inquiry first by examining what we call networks of association or interest (groups of actual women who corresponded with 
and worked in community with each other), and then by turning to what we term networks of meaning, within which authors and texts that may not traditionally seem to have any connection with each other interacted and spoke in unexpected ways. While our approach is far from comprehensive, we believe that it is a necessary first step towards opening up new ways of reading relationships between literary women both in and out of print, and of understanding their networks as living, breathing things, as personal and political, as literary and lived.

\section{Networks of Association and Interest}

In order to get a better idea of the 'shape' of women's networks during the Romantic period, the first half of this volume employs a variety of methods to trace the contours of networks of association and interest that bound diverse groups of women together. Many of the women who made up these networks are largely unknown today, even within scholarly circles, while others are only beginning to be recovered. What is clear is that women's literary networks extended far beyond the well-known coteries and Bluestocking circles centred in London and encompassed diverse groups of men and women from all walks of life and from every corner of Great Britain and the larger British Empire.

Sally Wesley's network embodies these observations: not only was Wesley an accomplished poet and scholar in her own right, she also maintained an extensive correspondence with some of the most notable literary women of her time. In addition to Elizabeth Hamilton, she is known to have corresponded or been on friendly terms with Marianne Thornton, Hannah More, Anna Letitia Barbauld, Hester Thrale Piozzi, and Martha Swinburne, just to name a few. She apparently circulated in manuscript and/or performed some of her poetry within this network of like-minded women. Hamilton had certainly seen it, as is indicated by her admonitory October 30, 1801 letter to her friend:

My pen would burn the paper when I come to speak of this vile drudgery business to which you so quietly submit. You to spend your time in translating stuff! It provokes my very soul to think of it. I know your talents, and I am not inclined to do injustice to my own. If I have written with success, how much more might you reasonably expect to meet with? ... I have within these three years made $£ 500$ by my writings, and what is to me a matter of much more moment, have, I trust been of some use to the minds of many young people.... If instead of pursuing my own plan, I had followed the line chalked out for me, by our dear plodding friend-what would have been the consequence? I should have been all this time employed making stupid compilations, of stupid authors, for stupid booksellers, and should have had two or 
three guineas dropping in at a time, which I should never have known myself a farthing richer for. ${ }^{3}$

Here Hamilton promotes her own talents and successes - a stance that flies in the face of the demure and self-effacing posture often expected of women writers. Furthermore, she explicitly highlights her financial gains and encourages Wesley to seek such gains as well. This advice, too, contrasts with the expectation that women wrote with 'purer' motivations than financial ones (though Hamilton also touts the didactic purposes of her writing - an important caveat for a woman writer at this time). Finally, Hamilton encourages Wesley to be an innovator rather than '[following] the line chalked out for [her]'. Despite Hamilton's encouragement Wesley, perhaps intentionally, never published her poetry and her prose essays were published anonymously. Like many of her younger literary friends - Marianne Francis (a granddaughter of Charles Burney and niece of the novelist Frances Burney), Elizabeth Benger (biographer of Elizabeth Hamilton), Agnes Bulmer, Mary Tighe, and Maria Spilsbury - Wesley preferred to circulate her work privately, not necessarily because publication was not open to her but because she preferred the interaction of this intimate circle of literary friends. A quick glance into Wesley's little-known literary network, then, indicates that such relationships have much to teach us about how women negotiated the tensions surrounding female authorship and assisted one another in the development of their careers.

Too often the assumption has been made about women's lives and writing that simply because they are 'obscure', simply because they have not been transmitted to us in the manner we have come to accept, they are not worth our attention. As the list of women included above exemplifies, while the published work of women like Barbauld, More, and (to a lesser extent) Hamilton has been largely recuperated within Romantic-era studies, the prolific literary work of other women in their networks - like Wesley, Francis, Swinburne, Benger, Elizabeth Heyrick, Susanna Watts, and Mary Berry - has not. This neglect is puzzling given the influence and importance of these women within their social sphere. To play devil's advocate, perhaps their work simply isn't that 'good' or aesthetically pleasing (though such terms are, of course, problematic at best, tending to reveal more about contemporary critical interests than about the work itself). Perhaps Wesley's poems were, as Frank Baker describes them, just 'conventional' versifying - the idle scribblings of a young woman - or perhaps she is simply too 'obscure' for serious notice. ${ }^{4}$ By the same token, perhaps Heyrick's and Watts' abolitionist work in the Midlands is simply too

${ }^{3}$ Methodist Archives and Research Centre, John Rylands Library, GB 135 DDWF 26/56.

${ }^{4}$ Frank Baker, 'Miss Sarah Wesley of Bristol - A Methodist Bluestocking', unpublished MS, Frank Baker Papers, Box 211, Duke University Library. 
'provincial' to matter in our larger reconstruction of the period. However, as Diane Menagh puts it in her study of Marianne Francis, 'obscurity' is a term that gets uniquely applied to women writers and carries with it all sorts of baggage:

Our reasons for reading the letters of the obscure, then, are manifold. We read letters found in attics and old writing desks for the same reasons we read a friend's - for instruction and amusement, for gossip and diversion, for unique insights as well as commonplace observations. We attempt to rescue the 'separate lives', or particular histories, from oblivion for the sake of common life as well as the individual. As we reconstruct the 'little separate lives', certainly we are curious about the facts, but quickly we learn they are scanty. Our interest turns toward our subject's imaginative life and her gallant struggle to sustain it. ${ }^{5}$

As Menagh eloquently points out, 'obscurity' often masks an intense inner and imaginative life that speaks to the common life - of a literary period, of a group of writers, of a circle of family and friends - and it is in the lives and writing of the 'obscure' that we find the details which illuminate a broader perspective.

Perhaps, alternately, women like Wesley, Benger, Heyrick, and Watts are simply victims of the sheer volume of women's writing yet to be recovered from this period. According to recent estimates, there were approximately 900 women who produced a total of 1402 books of poetry during the period between 1750 and 1830. Likewise, of the nearly 3,000 novels listed in the British Fiction database, nearly half (approximately 1375) were by women, and the Orlando database, which tracks women writers of all eras, had entries for 1300 writers in $2013 .{ }^{6}$ By necessity, the task of selecting and recovering these authors must be prioritized in some way, especially in an era of shrinking financial support for the humanities. The time, effort, and money necessary to seek out and properly research the work of someone like Sarah Wesley is significant. It does make some practical sense to focus on the work of someone who published a lot, like Hamilton or the Porter sisters. Thus, practically speaking, limited access to some manuscripts has limited the attention paid to them. This position is understandable, but it does not necessarily represent (as has been commonly assumed) an aesthetic judgement or measure of literary

${ }^{5}$ Diane Menagh, 'The Life of Marianne Francis: With an Account of Her Letters to Mrs. Piozzi an Old Friend of the Family', Bulletin of the New York Public Library, 80 (Spring 1977), p. 320.

${ }^{6}$ Devoney Looser, 'British Women Writers, Big Data and Big Biography, 1780-1830', Women's Writing, 22:2 (2015), pp. 165-71 (p. 165). 
worth. In any event, it would be impossible to even know whether the work by a given female author was 'good' (whatever that means) or not simply based on how often her name appears in the historical record.

A more interesting proposition is that women like Wesley, Heyrick, and Watts did not wish to be published in the traditional sense - did not see print as the ultimate goal for their work. Perhaps they preferred alternative methods of circulation, through scribal publication for example. The practice of scribal publication and circulation was, in fact, well established within the Bluestocking network. Anna Seward, for example, published her early poetry in manuscript for circulation among fellow Bluestockings. ${ }^{7}$ Earlier female poets, such as Elizabeth Singer Rowe, also shifted between manuscript and print publication in order to suit different rhetorical situations and different purposes for their poetry, something Kathryn King calls the 'tactical' use of manuscript and print. ${ }^{8}$ Heyrick and Watts even went so far as to sew abolitionist messages into work-bags which were used by the women in their Midlands network. In both of these cases, these different modes of circulation and network building allowed women a level of control over the production and circulation of their own work that they would not otherwise have been able to enjoy.

Indeed, recent scholarship speaks to the significance of these alternate forms of production and circulation. For example, Daniel White has traced how the associational practices of Dissent informed Romantic sociability, especially in the Aikin-Barbauld circle where family members exchanged and commented on work before publication," while Betty Schellenberg has performed a similar analysis of the Bluestockings by exposing the ways in which members of this circle corresponded with each other prior to print. ${ }^{10}$ More recently, Amy Culley has explored how Romantic-era life writing provided women with an opportunity to mediate and remediate each other's experiences in both manuscript and print within a literary or religious community. ${ }^{11}$ Perhaps most significantly, Margaret Ezell's influential Social Authorship and the Advent of Print convincingly demonstrates that social authorship and literary collaboration were not

${ }^{7}$ Claudia Thomas Kairoff, Anna Seward and the End of the Eighteenth Century (Baltimore: Johns Hopkins University Press, 2011).

${ }^{8}$ Kathryn King, 'Elizabeth Singer Rowe's Tactical Use of Manuscript and Print,' in Women's Writing and the Circulation of Ideas: Manuscript Publication in England, 1550-1800, ed. George L. Justice and Nathan Tinker (Cambridge: Cambridge University Press, 2002), pp. 58-81.

9 Daniel E. White, Early Romanticism and Religious Dissent (Cambridge: Cambridge University Press, 2006).

${ }^{10}$ Betty A. Schellenberg, 'Bluestocking Women and the Negotiation of Oral, Manuscript, and Print Cultures', in The History of British Women's Writing, 1750-1830: Volume 5, ed. Jacqueline M. Labbe (London: Palgrave Macmillan, 2010), pp. 63-83.

${ }^{11}$ Amy Culley, British Women's Life Writing, 1760-1840 (New York: Palgrave Macmillan, 2014). 
the exclusive province of the wealthy in coteries of elite men in London, but also of women living in the provinces. Ezell also challenges the progressive narrative of the triumph of print by illustrating that the lines between manuscript and print were blurred and fluid. Often manuscript production and circulation was an intentional choice that had nothing to do with a reluctance to enter public space and everything to do with intended audience and generic conventions. ${ }^{12}$ Indeed, Harriet Kramer Linkin has usefully explored how Mary Tighe's circulation of fifty copies of Psyche among her intimate circle led to remediation of the text in manuscript among a much larger circle - with friends of friends copying portions of the text and passing it on..$^{13}$ Though Tighe did not intend wide distribution of the text and it was not published in a mass edition until after her death, nevertheless the literary networks surrounding her ensured a degree of literary fame even during her own life.

\section{Networks of Meaning and the Construction of 'Romantic Literature'}

Networks of association or mutual interest were not the only type of network that operated during the Romantic period, however. As Susan Wolfson reminds us, networks of influence, knowledge, and meaning were created during this period 'as a literary consciousness, in a web of reciprocally transforming and transformative creative subjects - in what I term interaction. ${ }^{14}$ These interactions between authors 'in connection with other authors - whether on the bookshelf, or in the embodied company of someone else writing, or in relation to literary celebrity' (p. 1), created a sort of literary and cultural consciousness that permeated works we have come to think of as Romantic. The result of investigating such interactions is a radical revision of our understanding of authorial formation and self-recognition during the period. According to this perspective, 'authorial self-recognition takes shape as a reciprocal formation in a society of formations ... not in categorical rhetorics, but in specific sites and textual reflections of complex interaction' (p. 8). In other words, the authorial self only comes into being during the Romantic period in conversation with and reaction to other authors and other texts. This situation belies the assumption that, if the male Romantics represent individual literary genius (itself a problematic concept), then female Romantics must represent its other - textual production in domestic conversation and community. Early and influential accounts of women's Romanticism by Marlon Ross and Anne Mellor, while important in

\footnotetext{
${ }^{12}$ Margaret Ezell, Social Authorship and the Advent of Print (Baltimore: Johns Hopkins University Press, 2003).

${ }^{13}$ Harriet Kramer Linkin, 'Mary Tighe and Literary History: The Making of a Critical Reputation', Literature Compass 7.7 (2010), pp. 564-76 (p. 565).

${ }^{14}$ Susan J. Wolfson, Romantic Interactions: Social Being and the Turns of Literary Action (Baltimore: Johns Hopkins University Press, 2010), p. 1.
} 
revitalizing the study of women during the period, often uncritically reify this binary. A more robust exploration of women's literary networks during the Romantic period reveals just how invested male authors were in these networks as well, and the extent to which they too were part of a collaborative model of textual production, which directly contradicts their claims of individual genius.

Indeed, Gillian Russell and Clara Tuite have argued for the recuperation of Romantic sociability as a major means through which Romantic-era authors - male and female - oriented the self. They argue that this 'process of reconfiguration and realignment considerably expanded and in some cases threatened the literary public sphere by incorporating others - women, servants, the lower orders - which the paradigmatic coffee-house model of the public sphere could more easily ignore.'. ${ }^{15}$ Taking account of the role of sociability in Romanticism thus means destabilizing long-standing gendered authorial binaries (not to mention class boundaries) and the canons that they allow us to construct. Russell and Tuite also urge us not to 'focus solely on the sociability of literary circles but ... recognize its fluid interplay with other modes of sociability within British society as a whole' (p. 19). Eighteenth-century models of conversation, for example, which often took place outside of the privileged world of the coffee houses and salons, were a crucial factor in the development of the social space of Romanticism, as Jon Mee convincingly argues in Conversable Worlds. As Mee points out, while 'definitions of the field of literary production in terms of visionary genius or professional specialism grew apace and gathered cultural authority' during this period, 'they did not simply erase the understanding or practices of reading and writing as taking place within and between variously situated conversable worlds'. ${ }^{16}$ These eighteenth-century conventions of conversation and conversability structured how writers spoke with each other in person, through letters and manuscripts, and through textual production more broadly. Moreover, these real and/or imagined interlocutors exerted a tremendous textual force on authors during this period - creating webs and networks of meaning that continued to resonate throughout the nineteenth century and blurring familiar lines between literary periods. Conversation was not the only model of Romantic sociability on offer, though, and part of the project of this volume is to trace some of the discourse structures and patterns - from religious and evangelical discourse to Sadian libertinism to free love socialism - that are not traditionally associated with women's literary and social lives during this period.

\footnotetext{
${ }^{15}$ Gillian Russell and Clara Tuite, 'Introducing Romantic Sociability', in Romantic Sociability: Social Networks and Literary Culture in Britain, 1770-1840, ed. Gillian Russell and Clara Tuite (Cambridge: Cambridge University Press, 2006), pp. 1-23 (p. 19).

${ }^{16}$ Jon Mee, Conversable Worlds: Literature, Contention, and Community 1762 to 1830 (Oxford: Oxford University Press, 2011), p. 33.
} 
These relationships between readers and texts, however they are conceived, took place not only between the usual suspects (William and Dorothy Wordsworth, for example) but also among those on the 'margins' of Romanticism, as well as in less familiar forms. For example, one of Hannah More's most unusual and influential correspondents was Horace Walpole, while Anna Seward was in direct dialogue with Erasmus Darwin - both the man himself and his work. Often, however, the interactions between writers were indirect, built upon networks of common interest and constructions of meaning. These networks functioned as much upon signs and symbols as they did upon actual friendships, and offered a way for women writers in particular to define the self, and specifically the authorial self, against the dominant modes of Romantic discourse. Of particular importance to this study is the way that these networks of meaning helped women writers construct and interrogate gender in their works: Mary Shelley reading the Marquis de Sade, for example, or Elizabeth Barrett Browning reading the French socialist Charles Fourier. These networks and connections occur at the level of the text itself and inhere within it, as Susan Wolfson points out in Borderlines:

While no one would deny the information and force of context, there is a loss in discounting literary agency in the world, and a loss, moreover, in neglecting literature itself as a context in which the ways of the world are refracted by oppositional pressure, critical thinking. ${ }^{17}$

By thus reading 'literature itself as a context', as a space in which writers interacted, we can trace lines of connection, knowledge, and meaning across time and space. While this approach does not and should not ignore the importance of physical connections and networks, it does help us better understand how women spoke to and through various texts as a way of constructing gendered identities.

\section{Structure of this Volume}

In order to address the questions and issues laid out here, we have divided the current volume into two parts. Part One explores physical and relational networks: women and men who knew each other, corresponded with each other, and read each other's work; Part Two addresses networks of literary influence, citation, and knowledge among writers who did not necessarily know each other. This approach allows us to examine networks from multiple perspectives and using multiple methodologies. We make no claim to comprehensiveness

${ }^{17}$ Susan J. Wolfson, Borderlines: The Shiftings of Gender in British Romanticism (Stanford: Stanford University Press, 2008), pp. 1-2. 
here, but the essays we have included build on each other to paint a broad picture of how women's networks operated during the period.

To open the volume, Andrew Winckles (Chapter Two) explores the religious and literary network surrounding Sally Wesley. Wesley was at the center of a network of latter day Bluestockings who produced and circulated material around the turn of the nineteenth century. Of particular interest to this diverse group was the nature and influence of evangelical feeling and enthusiasm on British life and letters - something Wesley knew much about as the niece of the famous Methodist John Wesley and the daughter of the hymnist and poet Charles Wesley. Analysis of Wesley's network reveals members from all social and religious backgrounds debating and discussing the proper role of religious enthusiasm - arguing for the importance of a well-regulated enthusiasm to the creation and distribution of literary work. Winckles then proceeds to explore points of contact between these women and their works - from Wesley's manuscript poetry, to Elizabeth Hamilton's novels, to Maria Spilsbury's paintings - to reveal just how vital these networks of enthusiasm and religious devotion were to women's religious and literary identities.

In Chapter Three, Felicity James and Rebecca Shuttleworth pick up where Winckles leaves off, both chronologically and thematically, by tracing the local network surrounding Midlands abolitionists and writers Susanna Watts and Elizabeth Heyrick in the 1820s. Watts and Heyrick were at the center of a local network that engaged in multiple textual production and circulation practices in support of the cause of abolition. Of particular importance to this group were manuscript circulation practices that allowed women to operate outside of established print networks and circumvent increasingly restrictive cultural ideas about women's participation in political issues. James' and Shuttleworth's essay thus allows us to get a better ground-level view of how and why networks operated at the local level and how these networks influenced larger conversations about controversial political topics. In a similar vein, Amy Culley (Chapter Four) illustrates how relationships between women endured and matured over the course of their lifetimes as well as beyond the traditional chronological boundaries of the Romantic period. In this case, Culley explores the relationship between Joanna Baillie and Mary Berry and how their personal and literary friendship structured and influenced their work.

While the first three chapters in this volume adopt relatively traditional literary and archival methods to explore the structure, role, and function of literary networks on a micro level, the next two chapters adopt slightly different methods to gain a wider, more bird's-eye view of the shape of different networks and how information flowed through them. In the first of these chapters, Michelle Levy and Reese Irwin (Chapter Five) analyse the network of women authors who corresponded and published with the important firm of Cadell and Davies. Cadell and Davies (or C \& D), according to Levy and Irwin, 
operated as a common node or focal point in a network of women writers that included Frances Burney, Hannah Cowley, Felicia Hemans, Hannah More, Charlotte Smith, Ann Radcliffe, Helen Maria Williams, and many others. These women's correspondence with the male editors and publishers at C \& D reveal the professional and business side of women's interactions within publishing networks and shed important light on how these professional relationships helped women's work reach print. Though many of C \& D's authors did not correspond directly with each other, their association with C \& D ensured that they had a common reference point when writing, editing, and preparing their work for print.

In Chapter Six, Elisa Beshero-Bondar and Kellie Donovan-Condron utilize the data generated by the Digital Mitford project to trace the shifting shapes and structures of Mary Russell Mitford's networks over the course of her long life. Combining distant reading practices with digital humanities methods, Beshero-Bondar and Donovan-Condron first lay out the contours of Mitford's extensive network and then illustrate what its shifts over time tell us about her literary friendships and the way she and her friends saw their work into print. In particular, they illustrate that as Mitford's reputation and influence grew over her life, she began to rely less and less on male agents and intermediaries and instead began to act as her own agent for her own work and for other women in her network. While the scope of the data Beshero-Bondar and Donovan-Condron analyse precludes much close reading, the larger view they provide has much to tell us about the wider shape, structure, and functions of women's literary networks during this period and opens up productive avenues for future inquiry.

The second half of the book follows a different approach to understanding the importance and function of women's literary networks. Instead of tracing actual physical networks grounded in relationships between men and women, these chapters instead trace networks of citation, influence, knowledge, and affect. This approach recognizes that networks during the Romantic period were larger and more symbolic than just networks of correspondence. Instead, ideas also acted as links between unexpected authors and personalities.

For example, in her essay on Mary Tighe's 'citational network' (Chapter Seven), Harriet Kramer Linkin traces how numerous contemporary authors - including Anna Maria Porter, Anna Letitia Barbauld, Alicia Lefanu, Lady Morgan, and Felicia Hemans - invoke or cite Tighe in their own works. Though many of these women never knew Tighe personally, Linkin considers what those invocations suggest about lines of affiliation, the construction of aesthetic communities, and attempts to shape or forecast reception. In sum, she argues that these Romantic-era women writers created this citational network through the figure and work of Mary Tighe in order to call attention to her significance and to establish their own histories of influence and reception. 
In Chapter Eight, Robin Runia turns to Maria Edgeworth's Letters for Literary Ladies as a way of examining how the letter form itself functioned during the eighteenth century and made its way into other literary forms. In particular, she investigates how Edgeworth's relationships with Thomas Day and Mary Wollstonecraft influenced how she chose to structure her Letters and address them to different audiences for different purposes. Indeed, Runia argues that 'by acknowledging a divergence between the intended audience of 'A Letter from a Gentleman to his Friend upon the Birth of a Daughter, With the Answer', the 'Letters of Julia and Caroline', and the 'Essay', Edgeworth essentially manifests the equality of women's reasoning outside the confines of a woman's domestic sphere and the public world of print'. By attending to Edgeworth's intellectual and publishing networks, Runia illuminates her place in the print culture of her time and the English Romantic canon of our own.

Networks of influence also existed between writers who never met each other or were not even alive at the same time. Rebecca Nesvet (Chapter Nine), for example, explores the intertextual relationship between Mary Shelley and the Marquis de Sade. Scholars have long speculated about whether or not Shelley read Sade and on the role Sade's thinking and themes played in her works. In this essay Nesvet uncovers conclusive evidence that, not only had Shelley read Sade's 'Eugénie de Franval' (the concluding tale of his multivolume compilation Les Crimes de l'amour), but that she also consciously adapted this content in both Frankenstein and Mathilda. Most significantly, Nesvet concludes that this new evidence of Shelley having read Sade expands our understanding of Sade's global network, often assumed to be almost exclusively male. This analysis sheds light not only on Shelley's intellectual network, but also extends the influence of Sade's work beyond traditionally accepted bounds.

Finally, Eric Hood (Chapter Ten) pushes against scholarly assumptions about the periodization of Romanticism and about what constitutes a literary network. Specifically, he traces the ways in which Elizabeth Barrett Browning uses the French socialist Charles Fourier as an affective sign and symbol against which she defines herself in Aurora Lee. Fourier, Hood argues, forms one half of an 'affective network' with Barrett Browning in Aurora Lee, one which transcends generations and literary periods. Hood's point is not that Barrett Browning was directly influenced by Fourier or even that she intended Fourier to act as this type of sign in her text, but that they form an intellectual and affective intergenerational bond that was vital to Barrett Browning's own identity formation and literary work. The inclusion of Barrett Browning in a volume of essays on Romanticism may raise a few eyebrows in and of itself; given Hood's observations, it is our belief that the 1856 publication date of Aurora Leigh should cause us to productively question where, precisely, the boundaries of Romanticism are drawn. 
Our aim here is not for comprehensiveness - that would be impossible - but instead we want to suggest some productive avenues for inquiry into the range and scope of women's literary networks. We have only just begun to understand how women related to one another and to a broader public during the Romantic period and how these relationships and interactions fueled literary work; there is much more work to be done. Our hope is that these essays will spark more conversations, research, and debate on this topic and that the work begun here will be carried on within other scholarly networks and contexts.

\section{Bibliography}

Baker, Frank. 'Miss Sarah Wesley of Bristol - A Methodist Bluestocking'. Unpublished MS, Frank Baker Papers, Box 211, Duke University Library.

Culley, Amy. British Women's Life Writing, 1760-1840. New York: Palgrave Macmillan, 2014.

Ezell, Margaret. Social Authorship and the Advent of Print. Baltimore: Johns Hopkins University Press, 2003.

Kairoff, Claudia Thomas. Anna Seward and the End of the Eighteenth Century. Baltimore: Johns Hopkins University Press, 2012.

King, Kathryn. 'Elizabeth Singer Rowe's Tactical Use of Manuscript and Print', Women's Writing and the Circulation of Ideas: Manuscript Publication in England, 1550-1800, ed. George L. Justice and Nathan Tinker. Cambridge: Cambridge University Press, 2002.

Lamb, Charles and Mary Lamb. 'Charles Lamb to S. T. Coleridge', The Works of Charles and Mary Lamb, ed. E. V. Lucas. London: Methuen, 1905.

'Letter from Elizabeth Hamilton to Sarah Wesley, Oct. 31, 1801'. Methodist Archives and Research Centre, John Rylands Library. GB 135 DDWF 26/56.

Linkin, Harriet Kramer. 'Mary Tighe and Literary History: The Making of a Critical Reputation'. Literature Compass 7.7 (2010).

Looser, Devoney. 'British Women Writers, Big Data and Big Biography, 1780-1830'. Women's Writing 22:2 (2015).

Mee, Jon. Conversable Worlds: Literature, Contention, and Community 1762 to 1830. Oxford: Oxford University Press, 2011.

Menagh, Diane. 'The Life of Marianne Francis: With an Account of Her Letters to Mrs. Piozzi an Old Friend of the Family'. Bulletin of the New York Public Library 80 (Spring 1977).

O'Neill, Lindsay. The Opened Letter: Networking in the Early Modern British World. Philadelphia: University of Pennsylvania Press, 2014.

Russell, Gillian and Clara Tuite. 'Introducing Romantic Sociability', Romantic Sociability: Social Networks and Literary Culture in Britain, 1770-1840, ed. Gillian Russell and Clara Tuite. Cambridge: Cambridge University Press, 2006. Schellenberg, Betty A. 'Bluestocking Women and the Negotiation of Oral, Manuscript, and Print Cultures', The History of British Women's Writing, 
Introduction: "A Tribe of Authoresses"

1750-1830: Volume 5, ed. Jacqueline M. Labbe. London: Palgrave Macmillan, 2010.

White, Daniel E. Early Romanticism and Religious Dissent. Cambridge: Cambridge University Press, 2006.

Wolfson, Susan J. Borderlines: The Shiftings of Gender in British Romanticism. Stanford: Stanford University Press, 2008.

-. Romantic Interactions: Social Being and the Turns of Literary Action. Baltimore: Johns Hopkins University Press, 2010. 


\title{
Sisters of the Quill
}

\section{Sally Wesley, the Evangelical Bluestockings, and the Regulation of Enthusiasm}

\author{
Andrew O. Winckles
}

In his diary entry for May 27, 1812 Henry Crabb Robinson records the events of a party given at Elizabeth Benger's house in London:

Went to Miss Benger's in the evening, where I found a large party. Had some conversation with Miss Porter. She won upon me greatly. I was introduced to a character, - Miss Wesley, a niece of the celebrated John and the daughter of Samuel [sic] Wesley. She is said to be a devout and most actively benevolent woman. Eccentric in her habits, but most estimable in all the great points of character. A very lively little body, with a round short person, in a constant fidget of good-nature and harmless vanity. She has written novels, which do not sell; and is reported to have said, when she was introduced to Miss Edgeworth, 'We sisters of the quill ought to know each other'. She said she had friends of all sects in religion, and was glad she had, as she could not possibly become uncharitable ${ }^{1}$

Benger (1775-1827) was a sort of latter day Bluestocking who prided herself on her London coterie of literary figures. She herself was a historian and memoirist, perhaps most famous for her biographies of Ann Boleyn, Mary Queen of Scots, and Elizabeth Stuart and the memoir of her friend, the novelist Elizabeth Hamilton. Benger and Hamilton were both close friends of the Miss Wesley mentioned here. Sarah Wesley (1759-1828), most commonly known as Sally, was the only daughter of Charles Wesley and the niece of John Wesley. While I have not been able to uncover any evidence of Wesley

${ }^{1}$ Henry Crabb Robinson, Diary, Reminiscences, and Correspondence of Henry Crabb Robinson (Boston: Fields, Osgood, \& Co., 1870), I: pp. 248-9. 
writing, much less publishing, novels, she was a prolific poet and essayist in her own right, well respected in this circle of scholarly and literary women, though very little of her work seems to have found its way to print. Nevertheless, what this passage shows is women like Wesley and Benger at the center of a social, religious, and literary network in the early nineteenth century that has received very little scholarly attention. The Bluestockings of the previous generation - Elizabeth Montagu, Elizabeth Carter, Frances Burney, Hester Thrale Piozzi, even Wesley's own Aunt Patty Hall ${ }^{2}$ - have all begun to receive their due. Likewise Romantic-era authors like Maria Edgeworth and Elizabeth Hamilton are well known to scholars today and others like the Porter sisters are just beginning to have their works recovered. Women like Wesley, Benger, and (later) Marianne Francis, however, still operate in the shadows. Indeed, when their work has been noticed at all it has often been treated with the same type of condescension that characterized contemporary reactions to their work. Even Frank Baker, who did more than anyone else to compile research on Sally Wesley, dismisses her poetry as the effort of 'on the whole just a conventional versifier'. ${ }^{3}$

To my knowledge there has only been one modern examination of Wesley and her work, by Deanna P. Koretsky in an article titled, 'Sarah Wesley, British Methodism, and the Feminist Question, Again'. Koretsky recognizes that Wesley 'was a noteworthy poet and thinker whose work challenges and illuminates prevailing critical notions of women's political, religious, and creative voices at the end of the eighteenth century', and proceeds to argue that:

Her body of poetry performs a continuous struggle between religious piety and the assertion of female individualism, variously oscillating between the voice of the good Methodist daughter and that of the liberal rebel. This conflict underscores increasing awareness among critics of the need to reevaluate the complexity of associations between religious thought and the emergence of modern intellectual and social institutions. ${ }^{4}$

Koretsky is certainly correct in this assertion, which points to some of the reasons for Wesley's critical neglect - simply put, most critics are still grappling with what to do with a religious poet like Wesley who published

${ }^{2}$ Hall apparently took the young Wesley to visit Samuel Johnson on a number of occasions and she showed him her early poetry. Her brother, Charles Jr. reports that Johnson remarked to Patty Hall of Sally, 'Madam, she will do'.

${ }^{3}$ Frank Baker, 'Miss Sarah Wesley of Bristol - A Methodist Bluestocking', unpublished MS, Frank Baker Papers, Box 211, Duke University Library.

${ }^{4}$ Deanna P. Koretsky, 'Sarah Wesley, British Methodism, and the Feminist Question, Again', Eighteenth-Century Studies, 46.2 (2013), pp. 223-37, (pp. 223-4). 
primarily in manuscript or, when her work did appear in print, had it printed anonymously. ${ }^{5}$

I propose that Wesley did not wish to be published in the traditional sense - did not necessarily want her work to see print. Instead she preferred alternative methods of circulation, like scribal publication. The practice of scribal publication and circulation was, in fact, well established within the Bluestocking network. Anna Seward, for example, published her early poetry in manuscript for circulation among fellow Bluestockings. ${ }^{6}$ Earlier female poets like Elizabeth Singer Rowe also shifted between manuscript and print publication in order to suit different rhetorical situations and different purposes for their poetry. ${ }^{7}$ This manuscript tradition was also well established in Methodist discourse culture where women in particular often circulated manuscripts within defined social circles rather than submit them for print publication. ${ }^{8}$ This method allowed them a level of control over the production and circulation of their own work that they would not otherwise have been able to enjoy.

Using these diverse practices of manuscript production and circulation Sally Wesley participated in a loosely connected circle of intellectual and religious women at the turn of the century who were heavily influenced by Bluestockingism but also by Romanticism and the type of evangelicalism that John and Charles Wesley popularized throughout Great Britain during the eighteenth century. As such these women occupy a liminal space - they yearn for the Bluestocking community of the past, but are at the same time constrained and frustrated by changing social, literary, intellectual, and religious landscapes of the present. The very fact that these women have

${ }^{5}$ Frank Baker remarks that 'Tradition has it also that Sally frequently contributed to the Edinburgh Review, though here again an examination of the indexes to that periodical does not help us'. He nonetheless concludes that it is 'almost certain' that much of her writing was published. While indeed true that there is no concrete evidence of Wesley publishing in the Edinburgh Review, she definitely was publishing in The Monthly Magazine, Or British Register in 1809 and 1810 in a series of essays printed simply as the Journal of a Reflector', a fact which her closest correspondents seemed to be well aware of despite Wesley's anonymity.

${ }^{6}$ Claudia Thomas Kairoff, Anna Seward and the End of the Eighteenth Century (Baltimore: Johns Hopkins University Press, 2012).

7 Kathryn King, 'Elizabeth Singer Rowe's Tactical Use of Manuscript and Print', in Women's Writing and the Circulation of Ideas: Manuscript Publication in England, 1550-1800, ed. George L. Justice and Nathan Tinker (Cambridge: Cambridge University Press, 2002), pp. 158-81, (p. 160).

${ }^{8}$ Andrew O. Winckles, 'Pray for the Unworthy Scribbler: Oral, Manuscript, and Print Cultures of Early Methodist Women', in After Print: Manuscripts in the Eighteenth Century, ed. Rachael Scarborough King (Charlottesville, VA: University of Virginia Press, Forthcoming). 
read and want to be taken seriously by authors like Crabb Robinson, Lamb, Coleridge, and Wordsworth indicates that they are deeply invested in types of artistic and intellectual projects that we have come to know as Romanticism. It is also significant that these canonical Romantics seem so eager to flee from any association with these literary women, especially since many of the women (Hamilton, Joanna Baillie, Mary Robinson or Charlotte Smith, for example) influenced them. ${ }^{9}$ It should come as no surprise, then, that they seem so eager to dismiss this minor "tribe of authoresses" so easily. To take them seriously would be to admit their own intellectual debt and undercut their claims to artistic genius and originality.

Furthermore, taking seriously women's religious commitments helps us cut through some of the critical confusion over their work. Recent scholarship on Hannah More, for instance, has recuperated her evangelical commitments as an important lens through which to read her work instead of something to be ignored or derided. Anne Mellor, Mitzi Myers, Patricia Demers, and Anne Stott, for example, have all taken up More's evangelicalism as a major strain of her work and argued that this evangelicalism was directed as much against the establishment as it was against the poor. As Mellor points out, 'More's impassioned pleas to the Anglican clergy to play a central role in bringing about the moral reform of the national inspired numerous members of the clergy to join the Evangelical branch of the Church of England'. ${ }^{10}$ Likewise Jane Nardin has argued that More's views on the poor as expressed in her unpublished letters seem quite different from those that were edited and published posthumously by her biographers and thus cast a different light on her social conservatism. She argues that More, 'was angrier and more deeply critical of both church and state than ... [most scholars] allow. And her disaffection increased markedly during the $1790 s{ }^{\prime}{ }^{11}$ On the other side of the political spectrum, scholars have also begun to seriously examine the religious commitments of women like Mary Wollstonecraft. As Barbara Taylor has argued, Wollstonecraft's feminism has often been read solely in terms of secular liberalism and at the expense of her religious affiliations. However, Taylor notes that 'if Wollstonecraft's faith becomes a dead letter to us then

9 Stuart Curran, 'Romantic Poetry: The I Altered', in Romanticism and Feminism, ed. Anne K. Mellor (Bloomington: Indiana University Press, 1988), pp. 185-207.

${ }^{10}$ Anne K. Mellor, Mothers of the Nation: Women's Political Writing in England, 1780-1830 (Bloomington: Indiana University Press, 2000), p. 21. See also Mitzi Myers, 'Reform or Ruin: "A Revolution in Female Manners"', Studies in Eighteenth Century Culture (1982), pp. 199-216; Patricia Demers, The World of Hannah More (Lexington, KY: University of Kentucky Press, 1996); and Anne Stott, Hannah More: The First Victorian (Oxford: Oxford University Press, 2004).

${ }^{11}$ Jane Nardin, 'Hannah More and the Problem of Poverty', Texas Studies in Literature and Language 43.3 (2001), pp. 267-84, (p. 269). 
so does much of her feminism, so closely are they harnessed together.' ${ }^{12}$ Religion was clearly an integral part of women's lives during this period, thus it deserves to be taken seriously as an integral element of their works.

But what do we mean when we say the work by women in this network revolves around evangelical religion? That religion ties this network together? Whose religion? What do we even mean by religion in this context? What type of religion/secular/sacred practice? How did women contribute to this religiosity that goes beyond creed or simple belief (which are modern constructs anyway)? How does the variety of religious belief and experience represented in these women's works play out in dialogue and discussion in and among these networks? How is religion, belief, theology actually constructed in their work? How is it transmitted and internalized? How does the specific type of evangelicalism practised by most of these women change the way we and their contemporaries read them? What is evangelicalism in this context?

I can only begin to suggest some answers to these questions here; however these artists and networks can help us gain a better perspective on the roles religion and theology play in Romantic-era women's writing. It is often hiding in plain sight, but without an alternative perspective gained by examining women's literary and religious networks, we lack the context to see it. So much has been written about Jane Austen, for example, that the religious and theological elements of her work (which are in plain sight if anyone cares to look) have long been ignored. As Laura White argues, Austen's religious commitments are right on the surface of her texts but have long gone unnoticed because the 'foundational worldview of the Georgian Anglican Church and that of contemporary Christians differs considerably, and the presumptions each hold about the social and cultural role of the church are even farther apart'. Reading Austen's religion, then, becomes a task in recapturing her 'world of Anglican belief in all its strangeness and remoteness to modern readers.' ${ }^{13}$ Poets like Wesley come to us without so much critical baggage and/or cultural context. They allow us to more easily see what is on the surface, interrogate it, and then apply it more broadly to other women within these social and literary networks.

Indeed, though we have gotten better at looking for and talking about 'religion' in literary works, it is often a generic and generalized 'religion' which lacks any cultural or theological specificity. As Joanna de Groot and

12 Barbara Taylor, 'For the Love of God: Religion and Erotic Imagination in Wollstonecraft's Feminism', in Mary Wollstonecraft and 200 Years of Feminisms, ed. Eileen Janes Yeo (New York: New York University Press, 1997), pp. 16-35, (p. 16).

${ }^{13}$ Laura Mooneyham White, Jane Austen's Anglicanism (Burlington, VT: Ashgate, 2011), p. 4. See also Colin Jager, The Book of God: Secularization and Design in the Romantic Era (Philadelphia: University of Pennsylvania Press, 2007); and Roger E. Moore, Jane Austen and the Reformation (Abingdon: Routledge, 2016). 
Sue Morgan have recently argued, though historical and literary scholarship on women has undergone a distinct 'religious turn' over the past ten years, there is still a tendency to collapse theology 'into its wider and more visible counterpart, religion, ${ }^{14}$ and leave the theological components of a work un-interrogated. Perhaps this is simply ignorance of theology on the part of modern scholars who have not been taught to read it; but I think it is more than that, especially when it comes to women and religion. Simply put, women of the Romantic period like Wesley, like Hamilton, like Marianne Francis, who were interested in theology and theological questions wrote about it in different ways from men - partly due to necessity (no one would publish a theological treatise or sermon by a woman) - but partly because the social bonds these women cultivated within their literary networks offered alternative means of discussing and promulgating theological ideas. Ideas that had less to do with simple belief (assenting to a set of ideas) and ancient doctrine and more to do with religious experience as a multi-faceted and all-encompassing thing.

Indeed, I would argue that evangelical religion and theology offered a way for these latter day Bluestockings to deal with the shifting social, cultural, and artistic conditions of turn of the century Britain and that the literary networks which coalesced around their shared religious interests represented a significant means through which literary women formed, expressed, and published their ideas. In particular the debate over and discourse on the proper role for religious enthusiasm structures much of the work that this network produced and is a distinctive theme of their correspondence. The central question for Wesley and her network is whether or not religious enthusiasm, properly regulated, had a place in social and religious life. In this they turned to the discourses of Romanticism and evangelicalism for the means through which to understand and control their enthusiasm, to provide a proper outlet for it. These women clearly believed that religious feeling and emotion had a place in devotional life, but it needed to be placed in its proper context. Evangelical theology, mediated through their discourse and art, was one way to accomplish this goal. Evangelicalism, for women in Wesley's network, was not simply a matter of doctrine, but a way of experiencing and of being in the world, a way of mediating this vision to a wider audience; just as Romanticism was a way of expressing this vision in a new and compelling manner.

Furthermore I will argue that it was within these alternative social spaces - simultaneously personal, private, and public - that women like Sally

${ }^{14}$ Joanna de Groot and Sue Morgan, 'Beyond the "Religious Turn"?: Past, Present and Future Perspectives in Gender History', Gender and History 25.3 (2013), pp. 395-422, (p. 395). 
Wesley were able to find their voice within a social structure that largely excluded women from serious theological discussions. Wesley is a particularly instructive example in that she chose not to see her works into print just as Mary Tighe (whose mother Theodosia Blachford was a close friend of Wesley's) chose not to publish much of her poetry in a traditional manner. This does not mean, however, that these authors did not intend for their work to be read. Sally Wesley did not print her poetry and published her essays anonymously not because she was a private person, uncertain about her work's merit who did not wish her work to be read (note her comment to Edgeworth as reported by Crabb Robinson - she wants to be recognized as a woman of letters, she wants Coleridge to know who she is and to include her work in an anthology) but because it best suited her particular rhetorical purposes to circulate her poetry in manuscript among her network of likeminded friends and acquaintances - many of whom were themselves gifted writers and thinkers.

In order to better explore how these women navigated this complex religious and literary landscape I will first trace Wesley's network in more detail - focusing on her connections to various prominent women and how these literary friendships structured her own work. In particular I want to attend to how Wesley's poetry and prose circulated within her network - how she turned to other like-minded women for comment and critique of her work and the very real debate over the advisability of print publication that informs her correspondence, especially with authors like Elizabeth Hamilton. After tracing some of the ways in which Wesley circulated her work I will then explore the various ways that Wesley and women within her network used various modes of publication and circulation to address the question of religious enthusiasm and its role in public life. In particular I will focus on Wesley's letter to Anna Letitia Barbauld on the subject of Methodism and enthusiasm and Wesley's own manuscript poetry which often addresses the question of properly regulated religious feeling. I will then explore how other women in Wesley's circle, particularly Elizabeth Hamilton and Maria Spilsbury, addressed the issue of religious enthusiasm. Based on this evidence I will then return to the question of how religion and theology helped women like Sally Wesley structure and inform their artistic production in conversation with the shifting roles for women in Regency society and artistic movements like Romanticism. Though each woman chose a different method through which to express her artistic vision (manuscript, print, music, visual art, etc.) and often disagreed on these points, it was within this like-minded community of artistic women that women like Wesley were able to carve out a space for a distinctly womanist (if not feminist) theology of experiential religion. 


\section{Sally Wesley's Bluestocking Network and Manuscript Circulation}

Sarah Wesley's network of literary and religious women was extensive and diverse - connecting a wide variety of women who might otherwise not have known each other. The following table details the names I have been able to identify and track, some of their notable accomplishments or associations, and the number of letters Wesley wrote to and/or received from each woman and how she was connected to them:

Table 2.1: Letters to and from Sally Wesley

\begin{tabular}{|c|c|c|c|}
\hline \multirow[t]{2}{*}{ Name } & \multicolumn{2}{|c|}{ Letters } & \multirow[t]{2}{*}{ Background } \\
\hline & \multicolumn{2}{|c|}{ to $S W$ from $S W$} & \\
\hline Lucy Aikin & & 1 & $\begin{array}{l}\text { Niece of Anna Letitia Barbauld, } \\
\text { author of Epistles on Women }\end{array}$ \\
\hline $\begin{array}{l}\text { Lady Austen (Ann } \\
\text { Richardson) }\end{array}$ & 1 & 2 & $\begin{array}{l}\text { Friend and muse of the poet } \\
\text { William Cowper, wife of le Baron } \\
\text { de Tardif, French nobleman and } \\
\text { military officer. }\end{array}$ \\
\hline Anna Letitia Barbauld & 1 & 1 & $\begin{array}{l}\text { Poet and author of numerous } \\
\text { treatises on education. }\end{array}$ \\
\hline $\begin{array}{l}\text { Charlotte (Francis) } \\
\text { Barrett }\end{array}$ & 6 & & $\begin{array}{l}\text { Niece of Frances Burney, Grand- } \\
\text { daughter of Charles Burney, older } \\
\text { sister of Marianne Francis, mother } \\
\text { of travel writer Julia Charlotte } \\
\text { Maitland }\end{array}$ \\
\hline Louisa Barwell & & 1 & Musician and children's author \\
\hline Elizabeth Bates & 4 & & $\begin{array}{l}\text { Wife of Eli Bates, author of Rural } \\
\text { Philosophy - friend of Rebecca } \\
\text { Spilsbury. }\end{array}$ \\
\hline Elizabeth Benger & 1 & & $\begin{array}{l}\text { Historian and memoirist of } \\
\text { Elizabeth Hamilton }\end{array}$ \\
\hline Theodosia Blachford & a & & Mother of poet Mary Tighe \\
\hline Agnes Bulmer & b & & $\begin{array}{l}\text { Methodist poet - member of City } \\
\text { Road Society, author of the epic } \\
\text { Messiah's Kingdom. }\end{array}$ \\
\hline Maria Cosway & 3 & & $\begin{array}{l}\text { Noted artist, musician, composer } \\
\text { - married to the artist Richard } \\
\text { Cosway. Friend and lover of Thomas } \\
\text { Jefferson during his time in France. }\end{array}$ \\
\hline
\end{tabular}




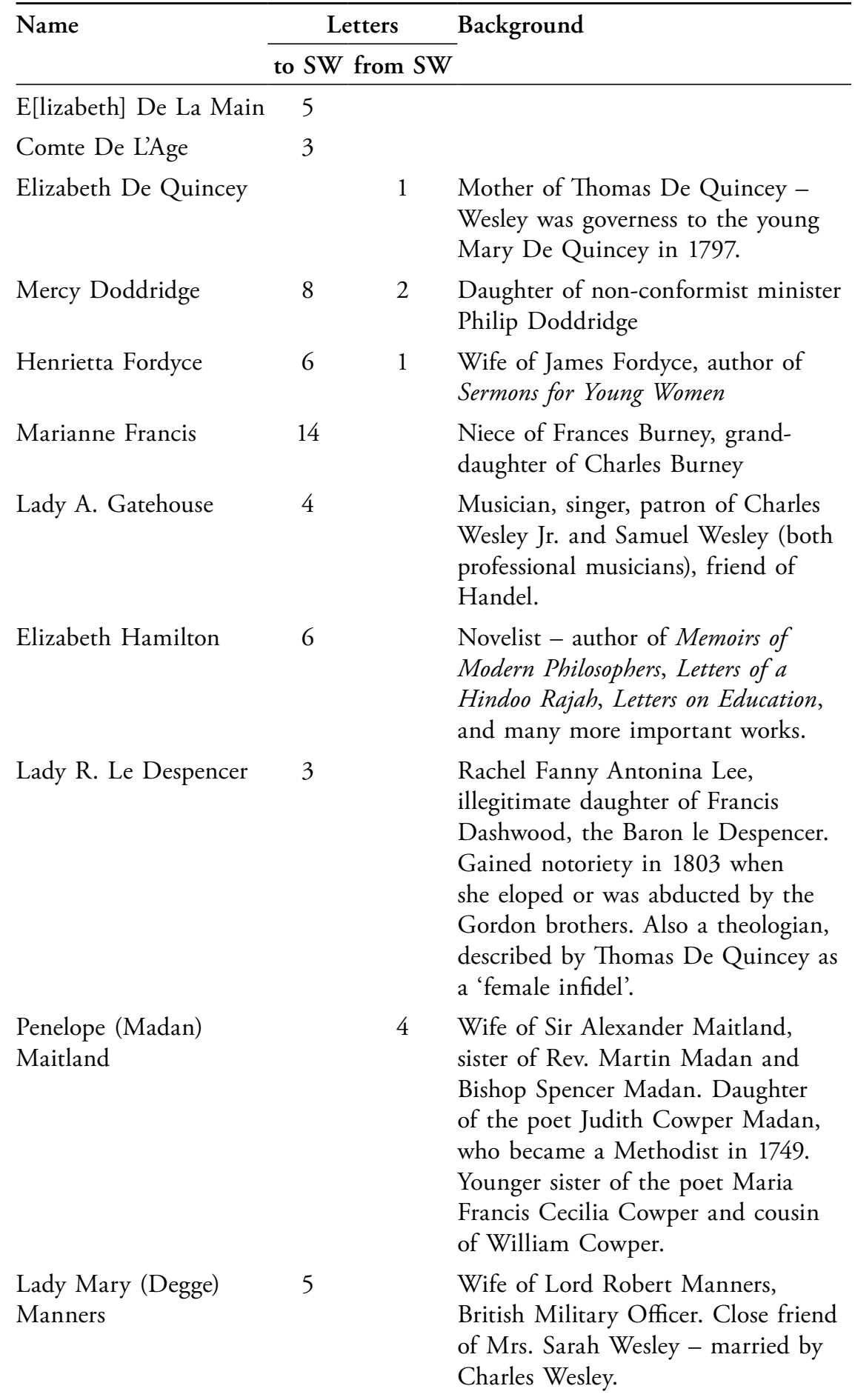




\begin{tabular}{|c|c|c|}
\hline \multirow[t]{2}{*}{ Name } & Letters & \multirow{2}{*}{${ }_{V}$ Background } \\
\hline & to $S W$ from $S W$ & \\
\hline Hannah More & c & $\begin{array}{l}\text { Prolific novelist, playwright, educator } \\
\text { - author of Strictures on the Modern } \\
\text { System of Female Education }\end{array}$ \\
\hline Martha More & d & $\begin{array}{l}\text { Sister of Hannah More - one of the } \\
\text { founders of the Mendip Schools and } \\
\text { compiler of Mendip Annals }\end{array}$ \\
\hline Mary Mortimer & 1 & Daughter of Elizabeth Mortimer \\
\hline $\begin{array}{l}\text { Elizabeth (Ritchie) } \\
\text { Mortimer }\end{array}$ & 5 & $\begin{array}{l}\text { Prominent Methodist leader - part } \\
\text { of important circle of female } \\
\text { Methodist preachers and writers. } \\
\text { Biography written by Agnes Bulmer. }\end{array}$ \\
\hline Hester Thrale Piozzi & e & \\
\hline Jane Porter & 1 & $\begin{array}{l}\text { Novelist and playwright - author } \\
\text { of historical fiction - The Scottish } \\
\text { Chiefs and The Pastor's Fireside. } \\
\text { Sister of Anna Maria Porter, also a } \\
\text { novelist with whom she frequently } \\
\text { collaborated. }\end{array}$ \\
\hline Elizabeth Spence & 2 & $\begin{array}{l}\text { Travel writer, novelist, friend of } \\
\text { Elizabeth Benger - may have written } \\
\text { a brief biography of Wesley for a } \\
\text { magazine. }\end{array}$ \\
\hline Rebecca Spilsbury & 3 & Mother of artist Maria Spilsbury \\
\hline Martha Swinburne & 4 & $\begin{array}{l}\text { Wife of Henry Swinburne, travel } \\
\text { writer and diplomat }\end{array}$ \\
\hline Marianne Thornton & 2 & $\begin{array}{l}\text { Wife of Claphamite Henry Thornton. } \\
\text { Great grandmother of E. M. Forster. }\end{array}$ \\
\hline Eliza Tooth & 3 & $\begin{array}{l}\text { Close friend and literary executor of } \\
\text { Sally Wesley }\end{array}$ \\
\hline Mary Wood & 1 & $\begin{array}{l}\text { Wife of James Wood, Methodist } \\
\text { minister in Manchester and former } \\
\text { President of the Methodist Conference }\end{array}$ \\
\hline
\end{tabular}

${ }^{a}$ Mentioned in Letters by Rebecca Spilsbury

b Mentioned in Bulmer's Memoir of Elizabeth Mortimer

c Mentioned in letters to and from Mercy Doddridge as one of Wesley's 'train of admirers'.

d Unclear signature but most likely from Martha More.

e Mentioned as mutual acquaintance in letters from Marianne Francis 
A cursory glance down this list reveals that Wesley was in close correspondence with many of the leading female artists of the day - painters (Spilsbury, Cosway), musicians (Louisa Barwell, Cosway, Lady Gatehouse), novelists (Hamilton, Porter, Hannah More), historians (Benger), theologians (DeSpencer), travel writers (Elizabeth Spence, Martha Swinburne), poets (Aikin, Barbauld, Bulmer), religious leaders (Elizabeth and Mary Mortimer, Mercy Doddridge, Mary Wood), and other notable learned women (DeQuincy, Francis, Fordyce) - many of whom are still obscure, others of whom were considered obscure only thirty years ago. Tracing all of the connections outlined in this table is beyond the scope of this chapter, however the extent of this list and the variety of connections Wesley cultivated is significant and indicates a gap in our knowledge about how turn of the century British women negotiated their social, literary, and religious identities in the context of shifting cultural attitudes and mores regarding women.

As a case in point, take the false private/public, manuscript/print binary which is uniquely applied to female artists and too often defines whether or not these female writers or artists receive modern critical attention. Often what determines whether a woman is still obscure or not is the extent to which she published her work in print - thus making it more easily recoverable by modern scholars using tools like Google Books and Eighteenth Century Collections Online (ECCO). Manuscript texts like, for example, Sally Wesley's poetry chapbook dated 1774, are difficult to access and even more difficult to analyze due to their lack of literary context. That said, Wesley's chapbook is a particularly good example of how a text manifestly not intended for print could still be circulated and commented upon widely. The chapbook itself is a simple notebook bound in paper containing about twenty pages and nine poems. The cover bears a penciled inscription (likely in another hand) reading: 'Sarah Wesley Early Poems To [Blank]' and dated 1774-1778. Who the poems are 'to' is unclear but they were clearly prepared for circulation.

Take, for example, Wesley's 'Sonnet' which is included in this collection. Not only has this poem been prepared and written out in Wesley's fair copy hand, but there are marginal comments written in a different hand which indicate an outside reader providing feedback on the text:

Sonnet

O navis referent in mare te novi Fluctus?

Hor Ode.

Forbear my Heart to tempt the Tide

And seek th' uncertain Coast

Oft' has the dang'rous Ford been tried

And oft' the Ship been lost 
Ford is not large or comprehensive enough. It means a shallow part of a river that may be passed without swimming where therefore it must be supposed a ship would never come. Strait would answer the purpose.

The Pilot Reason stays on Shore

The boist'rous Passions more

Youth is the Ship and Hope the Oar

And O! the Sea is Love!

May 1778

$\mathrm{SW}^{15}$

Except that [?] word I have censur'd, the whole of the rest is beautiful - I like it much.

Indeed, Wesley seems to have sent her poetry to several trusted correspondents over the course of her life in order to solicit their comments. In a brief letter to an unnamed correspondent Wesley asks that he provide her with written feedback on her work:

I take the liberty of offering a Manuscript which contains some of my casual Observations on Men \& Manners and some of my earliest Flights in Poetry.

I will make no Apology for doing this, as you desired me so to do If you have time to look over them before Saturday, on Saturday I will take them home with me; If not, they are yours till you have Leisure to return them.

I need not (I am persuaded) desire you not to give Copies - and I shall expect the favor of your written thoughts and Criticisms.

Permit me to call Myself my dear Sir what I really am with much esteem.

Your sincere obedient Servant

S Wesley ${ }^{16}$

I have been unable to ascertain whether this is the same collection of early 'Flights of Poetry' mentioned above, but it is no secret that Wesley circulated her work in manuscript to multiple correspondents. Elizabeth Hamilton and Mercy Doddridge had certainly read her work and discussed it together.

15 Wesley Family Series (WFS), Box WF4, Folder 4, Frank Baker Collection of Wesleyana and British Methodism, Duke University Libraries.

16 'Letter from Sally Wesley to Unknown', Methodist Archives and Research Centre (MARC), John Rylands Library, GB 135 DDWF 14/61. 
Doddridge, for example, writes to Wesley on 31 January 1801 that Hamilton 'talked of you with enthusiasm \& drew a Parallel between you $\&$ a certain Celebrated Authoress, that was decidedly in your favour. ${ }^{17}$ Likewise Wesley's cousin Thomas Waller possessed a notebook, apparently given to him by Wesley in 1780 , which contained a number of her earliest poems. After Waller's untimely death in 1781 at the age of thirteen the notebook came back into Wesley's possession. She then appears to have used it as a commonplace book and to draft original essays on various subjects.

Furthermore, Wesley is known to have copied her own poems into her friends' own commonplace books. These poems were then in turn copied from these commonplace books by other friends. In a letter dated 3 December 1796, for example, Mercy Doddridge describes this method of circulation:

The Poems you mention of Dr [Byrom's?] I remember to have read with pleasure many years ago. A few of them I have copied into the little $\mathrm{ms}$ vol to wch you have given much additional value by inserting with your own dear Hand your elegant Lines on Miss Burneys marriage with wch Miss Rose was so much pleas'd as to solicit a copy. I hesitated at first, but recollecting that my beloved Friend had not laid me under any restriction, I obliged her much by complying with her request. ${ }^{18}$

Likewise Wesley and her circle often circulated and commented upon each other's writing - published and unpublished. Wesley and Mercy Doddridge frequently discussed the works they had been reading, including Elizabeth Hamilton's and Hannah More's, and the women felt free to express disagreement with or criticism of other women's work. Wesley, for example, takes issue with several points in Hamilton's 1813 Series of Popular Essays, writing that 'tho she Evinces a mind which perseveringly contemplates its object, and has excellent remarks on the Ingredients of Criticism \& True Taste, she appears totally to confound what she calls "the magnifying Self" with that Individuality \& selfpreservation whereby the Almighty has constituted Man as Man and every Being endow'd with Consciousness. ${ }^{19}$ No doubt Wesley had no scruples about relaying these observations to her close friend Hamilton personally. ${ }^{20}$ Indeed, as Michelle Levy points out, 'a great proportion of the period's writing by both men and women arose within manuscript culture', and for women especially

${ }_{17}$ WFS, Box WF4, Folder 1, Baker Collection.

${ }^{18}$ Ibid.

${ }^{19}$ Ibid, Box WF4, Folder 3.

${ }^{20}$ A similar sort of give and take took place in Mary Russell Mitford's network, where women felt more at home critiquing each other's work in correspondence with each other. See Katie Halsey, “'Tell Me of Some Booklings”: Mary Russell Mitford's Female Literary Networks', Women's Writing 18.1 (2011), pp. 121-36. 
'writing of all kinds was a part of their daily lives, through which they not only developed their abilities but became accustomed to having their work received and critiqued by others. ${ }^{21}$ It was often after a manuscript had been read and critiqued within a small circle of friends and acquaintances that the author was encouraged to move on to print - though it is clear from their correspondence that women like Wesley did view manuscript circulation itself as a form of publication.

This does not mean, however, that Wesley was, as Baker would have it, an 'extremely reserved' (p. 9), modest and retiring character. Indeed, Wesley seems to have wanted recognition for her literary endeavors and to have sought it, not only from her female friends, but from noted male interlocutors like Dr. Gregory, the Rev. John Clowes of Manchester and also famous literary figures like Charles and Mary Lamb, Crabb Robinson, Coleridge, and even Wordsworth. This type of recognition and validation as a scholar and intellectual seems to have been more important to Wesley than any financial reward she might have reaped from publishing her work; indeed publishing poetry even as the daughter of a famous poet and niece of an even more famous religious leader was not a particularly safe bet and could potentially result in her losing money. ${ }^{22}$

In her seemingly contradictory desire to have her work read but not necessarily printed, Wesley was not alone. As Harriet Kramer Linkin has persuasively demonstrated, Mary Tighe had very particular audiences in mind when she first published Psyche and was operating within a specific rhetorical context that informed her decision to privately print only fifty copies to be distributed among her family and friends. Furthermore, the fact that Psyche was issued in such a small edition did not mean that only fifty people read it. As Linkin points out, even Tighe did not anticipate the 'extraordinary circulation those 50 copies underwent, which brought the poem to hundreds of enthusiastic readers, many of whom made their own manuscript copies (therein exponentially expanding the circulation network) ${ }^{2}{ }^{23}$ It was not until after her death in 1810 that a carefully edited collection of her poetry titled Psyche, and Other Poems

${ }^{21}$ Michelle Levy, 'Women and Print Culture, 1750-1830', in The History of British Women's Writing, 1750-1830, ed. Jacqueline Labbe (Basingstoke: Palgrave Macmillan, 2010), pp. 29-46, (p. 39).

22 Wesley would likely have had to reach an agreement with a publisher for the outright sale of the copyright to her poems. This would have been unattractive to her for a number of reasons: first she would have had to relinquish all control over her poems to the publisher and secondly she likely would not have received a very large sum for her work compared to someone like Hamilton who was a well-established author and who could publish on commission. See Levy, 'Women and Print Culture, 1750-1830'.

${ }^{23}$ Harriet Kramer Linkin, 'Mary Tighe and Literary History: The Making of a Critical Reputation', Literature Compass 7.7 (2010), pp. 564-76, (p. 565). 
was issued by her family in 1811, which did much to establish her reputation as a beautiful, tragic dead poetess - a characterization that is not at all evident in her privately prepared edition. ${ }^{24}$ Similarly, Tighe chose to leave her monumental novel Selena in manuscript form, though she very clearly allowed others to read it and even went so far as to read portions of it to others aloud. ${ }^{25}$ Likewise, Wesley seems to have valued the control that manuscript circulation and scribal publication gave her over her own work as it allowed her to control the conditions of its reception in a way that print publication did not.

\section{Dangerous Enthusiasm and Wesley's Literary Network}

A case in point is the way Wesley and women in her network negotiated the difficult question of the role of religious enthusiasm and evangelicalism in Christian practice and life, topics which were often greeted with suspicion or scorn when discussed publicly, especially within the context of national politics and the paranoia surrounding the war with France. Methodists were once again suspected of a dangerous and uncontrollable enthusiasm that was readily conflated with social disorder. In his 1800 Charge Bishop Samuel Horsley blithely conflates Jacobinism and Methodism, writing that 'The Jacobins of this country, I very much fear, are, at this moment making a tool of Methodism.'. ${ }^{26}$ Even the otherwise stalwartly conservative Hannah More came under suspicion during these years for employing a Methodist as teacher in one of her Mendip Schools during what became known as the Blagdon Controversy. ${ }^{27}$ Within this culture of scorn and suspicion Wesley and the women in her network sought to properly define a role for evangelical religion while at the same time ensuring that this type of enthusiasm could be properly regulated.

One of the best examples of how Wesley attempted to address the question of enthusiasm in a culture still suspicious of Methodism is represented in a letter she wrote to Anna Letitia Barbauld on 9 July 1807. The extent of Wesley's relationship with Barbauld is uncertain - they seem to have been acquainted socially at the very least and Wesley was certainly friendly with Barbauld's niece, the poet Lucy Aikin. Regardless, it was Wesley whom Barbauld consulted regarding the truth of a recently published book by a man

${ }^{24}$ Harriet Kramer Linkin, 'Mary Tighe and the Coterie of British Women Poets', The History of Women's Writing, 1750-1830, ed. Jacqueline M. Labbe (New York: Palgrave Macmillan, 2010), pp. 301-20.

${ }^{25}$ Harriet Kramer Linkin, 'Introduction', Selena: A Scholarly Edition (Burlington, VT: Ashgate, 2012), p. 3.

${ }^{26}$ Samuel Horsley, The Charge of Samuel Lord Bishop of Rochester, to the Clergy of his Diocese, Delivered at His Second General Visitation, in the Year 1800 (London: Robson, 1800), pp. 19-20.

27 Stott, Hannah More, pp. 241-2. 
named Joseph Nightingale titled A Portraiture of Methodism, which painted the movement in a negative light. Nightingale was a former Methodist preacher who, after growing disenchanted with Methodism, became a Unitarian and a part of the Barbauld/Aikin circle in London before eventually returning to the Methodist fold in 1824. Nightingale structures his Portraiture as a series of letters to Barbauld, writing in the introductory letter that, 'the last time I had the pleasure of dining at [Stoke Newington], you requested me to recommend to you some book containing an impartial account of the Wesleyan Methodists'. ${ }^{28} \mathrm{He}$ then proceeds to tell her that no such book exists and offers his own as an attempt to provide an impartial account. While Barbauld's letter to Wesley requesting her perspective is not extent, Wesley's reply - or a copy of it - is held by the John Rylands Library.

In this letter, Wesley clearly responds to an inquiry on Barbauld's part, opening her address by thanking her for sending a copy of Nightingale's book and apologizing for not calling on her in person. 'The intense Heat prevents my taking so long a walk as to Newington', she writes, 'and I am obliged to relinquish the pleasure of calling upon you'. She then moves on to the topic of the Portraiture which, she says, 'is not candidly written; when an author professes to esteem a Body of Men, and fills his Book with accounts which prove them undeserving of Esteem, his Evidence and his Judgment are alike questionable. ${ }^{29}$ She then refutes specific claims Nightingale makes in the text about her uncle and father - often drawing from her personal knowledge of family history to set the author straight. She specifically focuses on some of Nightingale's more outrageous claims about the rampant enthusiasm of the early Methodist movement:

He declares that at a Prayer Meeting he has seen a Preacher bite his lips with Anguish \& or gnash his Teeth with just indignation on finding himself so completely overpowered by the [obstreperousness] of his Audience that he has been obliged to sit down with fatigue in his Pulpit or wander from pew to pew to quiet the Tumult of which his own Sermon was the efficient cause. -

I can only say that I never head of or saw such Effects. ${ }^{30}$

Wesley goes to particular and understandable lengths to vindicate her father from charges of encouraging unhinged enthusiasm and takes umbrage at Nightingale's claims to know elements of Charles' personal history:

${ }^{28}$ Joseph Nightingale, A Portraiture of Methodism (London: Longman, Hurst, Rees, and Orme, 1807), pp. 1-2.

29 'Sarah Wesley to Anna Letitia Barbauld, July 9, 1807', MARC, GB 135 DDWF 14/22.

30 Ibid. 
The Rev'd Charles Wesley is represented as severe, haughty, dogmatical in his manners, tenacious of his opinions \& tinctured with Bigotry. This is another entire mistake. Humility was Characteristic; his opinions were delivered in a manner which proved it - in his Principles he was steady $\&$ his attachment to the Church of England might be called Bigotry.

'But he did not always check the Ecstasies \& wild Raptures into which his Eloquence often threw his Hearers'

He always did check them and had Mr. Nightingale been acquainted with CW or with any who had known him. He would have acknowledged this to be Truth.

$\cdots$

From my own Observation (if the testimony of a Daughter may be received) He appeared a uniform devout Christian in every little circumstance as well as great Event. ${ }^{31}$

Wesley's sarcasm here is barely concealed and we can only speculate as to what effect this letter had on Barbauld's opinion of the movement, though clearly she respected Wesley enough to ask her perspective in the first place. Most importantly, this letter seems to have been intended for greater circulation as a defense of Methodism, or at least the Wesleys. There are two copies of the manuscript in existence, one the letter addressed directly to Barbauld; and another prepared in Wesley's fair copy hand which removes all personal addresses to Barbauld and is constructed more as a formal essay on the subject. Whether or not this version was ever published (I have been able to uncover no evidence that it was) simply by sending her views to as influential a person as Barbauld guaranteed further circulation of her defense within Barbauld's own extensive social and literary network. This ensured that her views would gain wider circulation without exposing herself to the potentially unwanted attention that print would have engendered.

This concern about the proper place of enthusiasm within religious devotion extends to Wesley's poetry as well. As in the Sonnet quoted above which extols the 'Pilot Reason' which should guide youthful emotion, Wesley is particularly interested in how to balance reason with religious feeling - a balancing act which, perhaps more than anything else, defined evangelical theology at the turn of the century. Of particular interest is a long poem titled The Elopement, dated 1776, which exists in at least three distinct manuscript versions in Wesley's papers and which she clearly worked on over a long period of time. ${ }^{32}$

31 Ibid.

32 One at JRL, two in the Frank Baker Collection of Weslyana and British Methodism at Duke University Library - all quotes from JRL Manuscript GB 135 DDWF 14/68/22. 
The Elopement is constructed as a poetic dialogue which examines the results of acting upon various forms of enthusiasm on its characters. As the unnamed narrator of the poem relates in the introductory stanzas:

I aim not now at the sublime;

My Pen attempts in scribbling Rhyme

To paint the fond the foolish Case

Arising from indulging Fear

And strange it is tho' true to say

No Fancy decorate the Lay -

Anna is known too gen'rall'y

To need her Picture drawn by me;

The Virtues that inspire her Breast

Too num'rous are to be exprest.

Her Fault (from Fault no Age or Station

Is free) was want of Moderation

No medium did She ever know

T'wixt frantic joy and sable Woe.

Charlotte was giddy, young, and fair

And plac'd beneath my Lady's Care

Each Action had it's due Inspection

She nere stirr'd out without Protection.

Central to the story are the Lady Ann, or Anna, and her young ward Charlotte Heath, who runs off one day to visit her friend Ms. Angenbold without informing her guardian. Lady Ann overreacts, assuming her beautiful ward has eloped, and calls in a whole cast of characters to worry and speculate on where Charlotte could have gone-always expecting the worst as in this exchange with the more reasonable Mrs. Cattyn:

Mrs. Cattyn:

What now? what would you Madam say?

Lady Ann:

What Ma'am? Miss Charlotte's ran away -

Mrs. C:

Miss Charlotte run away! good Lord!

What whim is this - what left no word? 
Ann spoke not - and Selina then

replies, she's in St. Marten's Care

Mrs. Cattyn:

Miss Angenbold I do suppose

She's call'd to see - Oh Heavn's who knows

Cries Anna; but Her Speech it falter'd

Her Eyes her Form were strangely alter'd

Again with bursting Grief she sighs

And thus in broken Accents cries -

'Oh Ma'am! Miss Charlotte's come to Harm'!

\author{
Mrs. C: \\ Why does your Ladyship alarm \\ Your Mind with such fantastic fears \\ Miss Heath is surely come to Years
}

In the end it comes to light that indeed Miss Charlotte has merely gone to visit her friend Miss Angenbold and neglected to tell anyone; but the damage to Lady Ann's nerves is done and it falls to her son Mr. Charles to set both Charlotte and his mother straight:
Stop Charlotte - if my Mother I hear
I'll state the case and matter clear -
Miss Heath imprudent was, tis true but more imprudent far were you
To all the Servants mad to say
You fear'd that she had run away -
She went - but left a Message where
You follow'd and have found her there
Now had you to this place have run
(For run you did) and found her gone
Then might you with some reason scold
Now Cattyn speaks - 'Miss Angenbold
I'm sure (good natur'd Soul!) would nere
Injure Miss Heath a single Hair'

Throughout the poem Wesley portrays both the young Charlotte and the Lady Ann (who should know better) as slaves to different forms of enthusiasm which cloud their judgment - making them slaves to their emotions - in Lady Ann's case fear and in Charlotte's impulsivity. At the conclusion of the poem she returns to her unnamed narrator, who spells out the moral of the story: 
A Visit now had broke the Thread

Where much had been of Nothing made

the Parties each broke up - (tho' past

Long since the Scene, each still holds fast

The Notion they had first profest

Thine Cattyn was the wisest! best!

The Moral from this scene we draw

Is, let it be a settled Law

Ye unto whom the guardian Care

Of Youth is trusted, Oh beware

Of Letting them perceive your Fear.

The bands of Duty must be tied

By Love or they will not abide

Place then or seem to place reliance

And the return will be Compliance

For no Temptation can remove

A Duty founded upon Love.

In this conclusion, Wesley attempts thus to foreclose these different expressions of harmful enthusiasm and redirect them towards proper devotional reverence for established authority and duty founded upon love. At the same time she does not endorse duty for duty's sake, but instead emphasizes that those in positions of authority, like Lady Ann, must not rely on fear to set an example, lest they too be led astray by a dangerous enthusiasm.

Concern over how to balance legitimate religious feelings with sober religious reflection and reverence is a common theme among members of Wesley's extended literary network. Hamilton, for instance, often returns to this theme in her novels and letters. Memoirs of Modern Philosophers, which is often read solely as a political novel and a response to the Revolution controversy and 'new philosophy' is also deeply concerned with the proper role of religion in social life and the ways in which religious enthusiasm and political enthusiasm are often intertwined. ${ }^{33}$ The ridiculous radical philosopher Mr. Myope, for example, is a 'convert' to the new philosophy from Methodism. The opportunistic rake Vallaton, 'having formerly known Myope in the character of an itinerant preacher', at first takes 'care to season his speeches with such pious phrases, concerning his wonderful deliverance, as he thought would be pleasing to the ears of his benefactor', in hopes of getting money from him. Myope, for his part, will have none of it and informs Vallaton 'of his having

${ }^{3}$ See Jon Mee, Romanticism, Enthusiasm, and Regulation: Poetics and the Policing of Culture in the Romantic Period (Oxford: Oxford University Press, 2003). 
become a convert to the new philosophy; and by the enthusiastic warmth of his eulogium, convinced him [Vallaton] that if he wished to ingratiate himself in his affection, he could not take a more effectual method than by espousing the doctrines he had embraced'. ${ }^{34}$ Here we find out that Myope has in fact been an itinerant preacher - a type of 'irregular' and dangerous religious practice that John Wesley pioneered. ${ }^{35}$ Likewise the language of religious enthusiasm and political philosophy is conflated throughout this passage. Myope 'converts' to the new philosophy, his eulogium is full of 'enthusiastic warmth' through which Vallaton himself is influenced to change his tactics.

This new philosophy works in a similar way on the young and conventionally pious Julia Delmond, who falls in love with Vallaton and through him is converted to the new philosophy. It is not really the philosophy she converts to, however, but rather the enthusiastic means through which it is mediated to her and to which she is particularly susceptible due to her propensity for reading romances. Take, as one example among many, the following passage which describes the turbulent and excitable state of her mind:

While following the course of an unreined imagination, she [Julia] experienced that deluding species of delight, which rather intoxicates than exhilarates, and which, by its inebriating quality, gives to the sanguine votary of fancy a disrelish for the common enjoyments of life; the eagerness with which her mind grasped at the idea of an extraordinary felicity, agitated her whole frame, and deprived her of peace and rest. Still she pursued the flattering dream of fancy, and kept her mind's eye so fixed upon its airy visions, that she at length believed in their reality, and what appeared at first the mere suggestion of imagination, seemed in the sequel the certain dictates of truth (p. 75, emphasis mine)

Rather than reflect on whether or not her enthusiastic thoughts are based in reality or fancy, Julia simply accepts them as truth. This tendency creates a type of dangerous enthusiasm within which there is no room for meditation or sober reflection. Julia is caught up in the rhetoric of Vallaton and how it makes her feel and is not particularly interested in whether or not this feeling is confirmed by experience.

This is not to say that Hamilton or Wesley denies the power or necessity of evangelical religion, but they do seek to distance it from the more extreme

\footnotetext{
${ }^{34}$ Elizabeth Hamilton, Memoirs of Modern Philosophers, ed. Claire Grogan (Peterborough, Ontario: Broadview, 2000), p. 59.

35 Early on in his ministry John Wesley began using un-ordained itinerant preachers who travelled preaching circuits throughout the country. This aroused significant controversy, especially among parish priests and ecclesiastical authorities who believed these untrained preachers were usurping the authority of the established Church.
} 
types of enthusiasm which end in political radicalism. The pious Harriet Orwell and Henry Sydney, for instance, are no mere representatives of the religious establishment. While their characters may seem static and boring in comparison to the flamboyant Ms. Botherim or the tragic Julia Delmond, they represent the proper role for religious enthusiasm - controlled, regulated, reverent, and directed towards God and humankind. In fact, while describing his travels in Scotland Sydney comments on the common mode of religious practice there, which he approves of:

I accompanied my host and his family to the Elder's barn, which was already occupied by a very numerous assemblage of country people of each sex and all ages, decently dressed, and devoutly attentive.

Every one rose at the entrance of the minister, who after going the round, like the king at levee, and like him finding something kind and agreeable to say to every individual, began the business of the day by a short prayer. All the children were then called up by name, and questions put to each, suited to their respective ages and capacities. Where any instance of ignorance or neglect appeared, not only the children, but the parents were rebuked and admonished. The seniors next formed a circle round their pastor, and underwent a very long and strict examination concerning their knowledge in the articles of faith and principles of conduct. Another short but well-adapted prayer concluded the ceremony. (pp. 116-17)

If we didn't know any better this could be a description of a Methodist class meeting - it takes place outside of a Church building, includes ex tempore prayer, and close examination of adults and children with regards to their spiritual state. ${ }^{36}$ This similarity is not lost on Henry Sydney's listeners. Mrs. Botherim, whose late husband was a rather stuffy clergyman in the Church of England, exclaims that this 'is no better than downright methodism!' and that her late husband 'would ha' given no encouragement to such practices, I assure ye. He would no more have prayed in the middle of the day in that there manner than he would have ate a pig with pruen sauce, and every one knows how nice he was in that particular' (pp. 116-17).

36 The influential Methodist preacher Mary Bosanquet Fletcher often preached in a large barn outside of Madeley in Shropshire. Class and band meetings were smaller organizational units pioneered by Wesley that met weekly for spiritual discussion and examination. Both the practice of ex tempore prayer and field preaching were greeted with suspicion during the early years of the revival because they were seen to encourage unregulated enthusiasm and (in the case of the latter) attracted large and sometimes unruly crowds. For more on the life and work of Bosanquet Fletcher see Phyllis Mack, Heart Religion in the British Enlightenment and Christine Krueger, The Reader's Repentance. 
Mrs. Botherim's mistake is that she fails to properly distinguish between what Hamilton sees as two distinct forms of enthusiasm, a distinction which Hamilton makes clear in her lengthy description of Mr. Myope later in the text:

The more Mr. Myope considered the subject, the more was he impressed with an idea of its importance His mind, ever under the influence of some one darling idea, which, during the period of its reign, excluded every other thought, was soon kindled to enthusiasm. It must be confessed, however, that the enthusiasm of Mr. Myope differed very materially from that which distinguishes great minds in the pursuit of some favourite object; it was of a nature very distinct from that sublime energy of the soul which, on the most extensive and comprehensive views, concentrates all its powers towards the accomplishment of some grand design. Indeed, no two principles of action are more opposite to each other in their nature, origin, progress, and consequences, than the two different species of enthusiasm here described. The first, born of reason and directed by judgment, is noble, discriminating, and effective. The other, the produce of an inflammable imagination, is blinded by the glare of its own bewildering light, expends itself upon any object that chance puts in its reach, and is usually unsteady as it is abortive.

Such was the enthusiasm of Mr. Myope. (pp. 144-5)

One type of enthusiasm, embodied here by Mr. Myope, is dangerous; it grasps at any thought that comes through the mind and acts on it without reflection; the other (embodied by Sydney and Harriet Orwell) applies proper reflection to the inspiration of the moment and then translates this into pious action. This second type of enthusiasm, which is characterized by a 'sublime energy of the soul which, on the most extensive and comprehensive views, concentrates all its powers towards the accomplishment of some grand design', and is 'born of reason and directed by judgment' could be a synonym for the type of evangelicalism, and Romanticism, which Hamilton's work embodies - an 'emotion recollected in tranquility' that is then directed outwards towards God and others.

Maria Spilsbury's religious paintings are another example of how a woman connected to this network sought to negotiate this same terrain. ${ }^{37}$ Sally Wesley was friendly with Maria's mother, Rebecca Spilsbury and the Spilsburys, along with the Blachford/Tighes were some of John Wesley's most notable followers in Ireland. Not surprisingly Maria's paintings reflect many of these influences. Her 'John Wesley Preaching in Ireland, 1789', (Figure 2.1) for example, is fasci-

${ }^{37}$ See Charlotte Yeldham, Maria Spilsbury: Artist and Evangelical (Burlington, VT: Ashgate, 2010). 


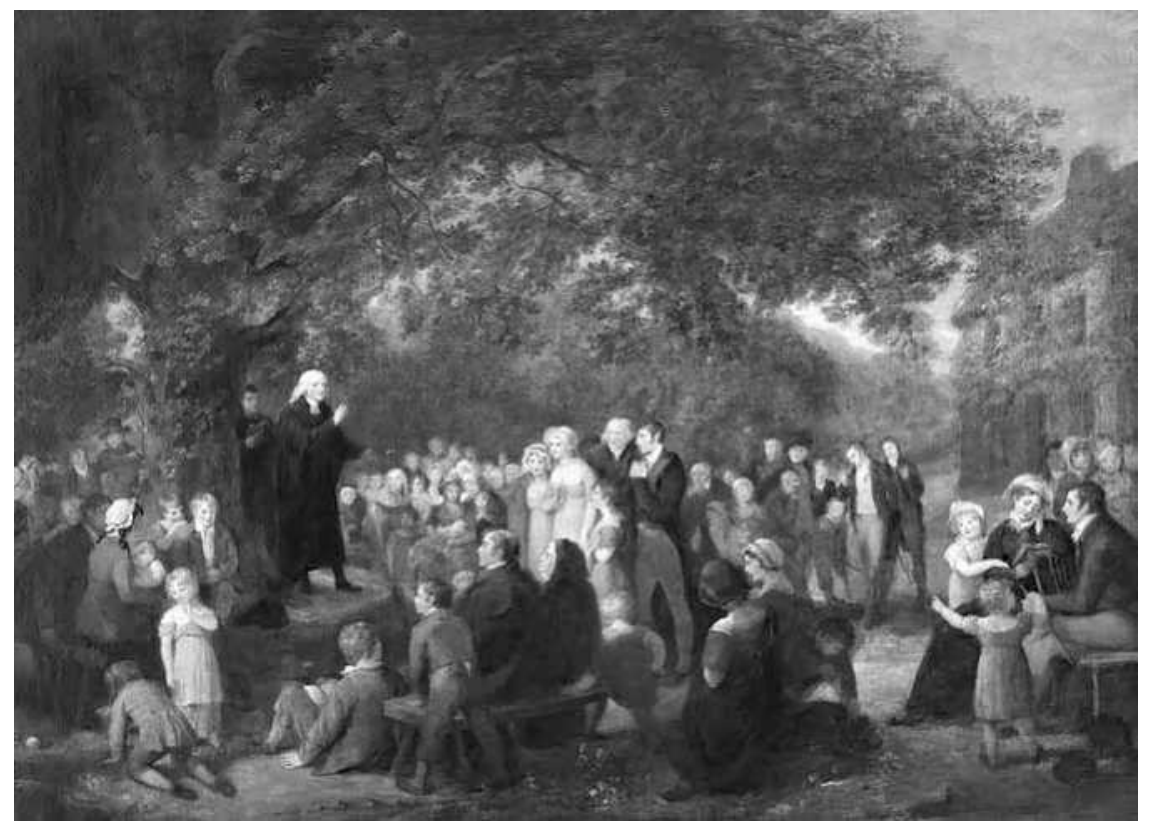

Figure 2.1: John Wesley Preaching in Ireland, 1789, by Maria Spilsbury, unknown date. Reproduced with the permission of The Trustees of Wesley's Chapel,

City Road, London.

nating for the way it portrays an elderly Wesley preaching in the open air while a decidedly pastoral, peaceful, and comfortably domestic audience looks on.

Unlike earlier portrayals of the evangelical revival, and particularly portrayals of the controversial practice of open air preaching which marked the preacher as an enthusiast (see Figure 2.2), here Spilsbury paints Wesley preaching on a small scale. The scene is decidedly rural and the audience is sedate, made up of distinct family groups who are reverently looking on. Most of the figures are seated and the canopy of the tree above Wesley extends out almost like a natural chapel. In the background is a respectable country house, covered in ivy. The overall effect of the painting is to diffuse the potentially dangerous enthusiasm of this public preaching act and redirect it towards a properly reflective, meditative, and domestic devotion. The goal is not to erase evangelical feeling - note the intent and passionate looks on the faces of some of the audience members - but to temper it, to direct it towards proper ends.

Spilsbury's paintings, along with Wesley's and Hamilton's writing, help us get at larger questions about artistic influence and the role these social networks played in the lives and work of female artists at the turn of the nineteenth century. As is readily apparent upon even a cursory glance at Spilsbury's paintings, Romanticism and evangelicalism are at the heart of her 


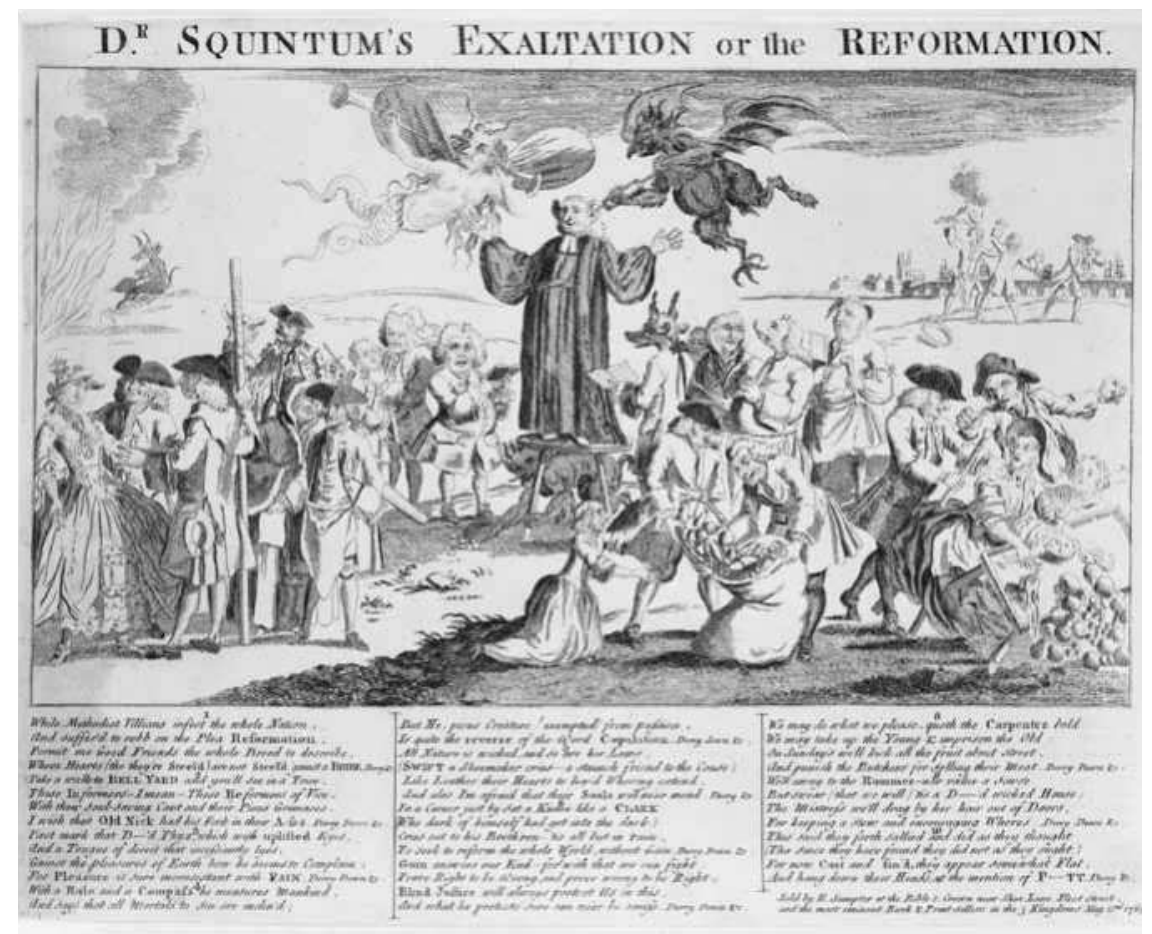

Figure 2.2: Dr. Squintum's Exaltation or the Reformation (1763)

(Library of Congress, no known restrictions on publication)

artistic vision. The sweeping landscapes, the natural chapels and cathedrals, the ancient buildings wreathed in ivy - the portrait of Wesley preaching is a fundamentally Romantic one - locating the 'new' and innovative religious revivalism of Methodism within a religious context as ancient as the tree which Wesley stands under. As Jon Mee points out, Romanticism itself acted as a sort of regulating force to religious enthusiasm - taking and transforming this impulse into artistic expression. ${ }^{38}$ Likewise Cragwall has recently argued that evangelicalism and Methodism acted, not as the fanatical other of abstracted secular high Romantic argument, but instead as a vital interlocutor and sometimes partner with Romanticism. ${ }^{39}$ Evangelicalism provided the women in this network with a way to properly regulate enthusiastic feeling in their lives just as Romanticism provided them with a way to regulate it in their poetry,

38 Mee, Romanticism, Enthusiasm, and Regulation.

39 Jasper Cragwall, Lake Methodism: Polite Literature and Popular Religion in England, 1780-1830 (Columbus, OH: Ohio State University Press, 2013). 
prose, and visual art. What they are working out in conversation with each other and in their work is just how these tools can be best applied.

Likewise Sally Wesley's poetry is fundamentally interested in carving out a space for emotion, for feeling, for enthusiastic and prophetic expression, within defined forms and structures of poetic diction. Take, as one final example, her 1775 poem 'Aurelia':

Aurelia (sweet unhappy Maid!) arose

Bright as the blushing rose - buds opning bloom;

What Eye can read the History of her woes

Nor drop the [Tear] of Pity o're her Tomb?

Her Heart by Nature kind and prone to Love

No faithful Friend that tender Heart to guide

Her air, her Face, her Voice were form'd to move -

Ensnard by Man Aurelia turn'd aside.

Soon was she scornd for having soon believ'd

The Wretch who stab'd her Peace refus'd to save,

Derided, shun'd, forsaken and decieved

Her last sad Refuge was th' untimely Grave

A green grass sod scarce rising to the view

A gloomy shade where Sun beams never rise

Two spreading Oaks and one tall fun'ral Yew

Mark the lone spot where soft Aurelia lies.

Since 'females frailty females pity claim'

The generous Tear shall on her Dust be shed

And as her Dust so hide her hapless name

It was to Love and not to Guilt she fled.

By sad Experience when she found them join'd

Her virtuous Heart was torn with wild Dispair

With Pangs she blamd that sence by Love made blind

Petition'd Heaven - and gaind its pardon there. ${ }^{40}$

The effect of this tragic and passionate lyric puts the reader very much in mind of Wordsworth's 'The Thorn', though it would, of course, be over twenty years before Wordsworth would publish that poem. If Romanticism is part of

40 'Aurelia', WFS, Box WF4, Folder 3, Baker Collection. 
this conversation though, then religion, and more specifically an evangelical theology of experience, is also an important part of the conversation. If an interest in Romantic poetry by Wordsworth and Coleridge holds women like Wesley, Hamilton, and Benger together; if a desire for an intellectual friendship along the lines of the Bluestockings is part of what they are trying to recreate, then religion certainly is also a vital element of their literary friendship and work. More than that, evangelical religion is the lynchpin that ties these other elements together for religion is a fundamentally social and relational thing. It is about a relationship with the divine and a relationship with others - and it was within these literary and religious discourse communities that these women learned how to rightly regulate and direct their enthusiasm towards common religious and artistic goals.

This is important. Religion did not mean something general or abstract to the women who were writing about it. It meant something(s) specific and well differentiated that went beyond denominational or sectarian affiliation. As Wesley remarked to Crabb Robinson, she had 'friends of all sects in religion, and was glad she had, as she could not possibly become uncharitable' (pp. 248-9). Wesley herself was a 'Church Methodist,', ${ }^{41}$ Hamilton was a dissenter, as were the Aikin/Barbauld's and Mercy Doddridge. Marianne Thornton, Henrietta Fordyce, and the More sisters were evangelical Anglicans. Martha Swinburne was a Catholic, Mrs. R. F. A. Lee was a professed atheist, while Marianne Francis became a millenarian later in life. These differences, however, were less important than the fact that all of these women agreed on the importance of understanding the role of enthusiasm and emotion in religious practice, or at least they all believed this was up for debate. For them, this was not merely a generically 'religious' topic, but a theological debate over the very essence of religious experience and how religion was lived in everyday life.

Likewise religion was not merely a question of right belief for these women, but a question of lived experience and social interaction, which were the hallmarks of evangelical theology. As the pious Martha Goodwin puts it in Hamilton's Memoirs of Modern Philosophers, 'I have often thought it a great pity that the heads of our church had not, instead of prescribing confessions of faith with regard to abstruse and speculative points of doctrine, confined themselves to those which are chiefly insisted upon in the discourses of our Saviour' (p. 104) and particularly the commands to love God and love others.

\footnotetext{
${ }^{41}$ A Methodist who remained an active member of the Church of England. John Wesley always maintained that he had no intention of separating from the Established Church and would not hold Methodist meetings during Church hours. After his death the Methodists gradually drifted away from the Church though pockets (including the City Road Chapel of which Sally was a member) remained strongholds of Church Methodism well into the nineteenth century.
} 
On the other hand, Mr. Myope's chief fault is that, instead of practicing his faith he simply wanders 'from maze to maze, in the intricate labyrinth of polemical divinity, without having once caught a glance of the sublime views, the simple but elevating principles of that religion, from which each of the different sectaries he embraced professed to be derived' (p. 145). Because Myope has no way of putting his principles into action he falls prey to every new idea and philosophy. He has no means of rooting his belief within a defined faith and discourse community - all he has is abstract doctrines with no foundation in social life and practice.

Furthermore, where one came down on these contentious theological issues had very real political and social implications. The attempts to privatize and feminize this form of religiosity as a way of robbing it of its force is part of the narrative of both Methodism's increasing conservatism and the development of Victorian gender ideology. Wesley's project, along with the women in her network and those who came after her, was to legitimize these forms of regulated and reverential religious expression within a public space - to carve out a role for a theology by and for women within a social and religious sphere that was increasingly hostile to it.

More importantly, these female artists set the stage for a generation of younger artists like Marianne Francis, Agnes Bulmer, and Felicia Hemans who would face even greater constraints in trying to find a public voice for their theology and who were thus forced to adapt their content within acceptable poetic and artistic constraints. Felicia Hemans, for example, often gets interpreted within the poetess or devotional poetry tradition but what she is really doing in her poetry is theology. What is more it is theology in its proper context - in conversation with emotion, enthusiasm, art, and poetic expression. It is theology that encompasses the whole of the human experience with the divine. It may not be the male-centric systematic theology of someone like Jonathan Edwards, whose Religious Affections treats many of the same subjects as the women in this network, or the higher criticism of someone like Coleridge, but it is its own type of theology - reverential, experiential, and deeply rooted in women's experience of and in the world.

Such a comprehensive vision could not be accomplished by an individual artist or poet, no matter how talented. In order to achieve these goals Wesley and her network used the means available to them: manuscript circulation and publication, personal letters and journals, anonymous essays, novels, poetry, painting, etc. In essence they are dialoguing on and working out these theological questions in conversation with each other and through their artistic expression. By locating these theological discussions in discourse, these women were able to carve out a space for women's theological discussion and ground their vision of religious experience firmly within this social space. Theology, like poetry, was no longer the province of the individual and original genius, 
but a social act and one that transcended sectarian affiliation. After all prayer, letter writing, common placing, and manuscript circulation are all fundamentally social, they are mediated events and they should be understood as part of a culture of mediation heavily informed by a properly regulated evangelical enthusiasm. Literary networks like the one Sally Wesley participated in thus help us better understand this phenomenon - help us 'hear' what is no longer there, what is not preserved in the printed record dominated by men, and helps us see how Romanticism and evangelical feeling were intertwined from the very beginning despite the efforts of men like Coleridge, Lamb, and Robinson to erase or elide the influence of this troublesome 'tribe' of authoresses and enthusiasts.

\section{Bibliography}

Baker, Frank. 'Miss Sarah Wesley of Bristol - A Methodist Bluestocking'. Unpublished MS, Frank Baker Papers, Box 211, Duke University Library.

Crabb Robinson, Henry. Diary, Reminiscences, and Correspondence of Henry Crabb Robinson. Boston: Fields, Osgood, \& Co., 1870.

Cragwall, Jasper. Lake Methodism: Polite Literature and Popular Religion in England, 1780-1830. Columbus, OH: Ohio State University Press, 2013.

Curran, Stuart. 'Romantic Poetry: The I Altered', Romanticism and Feminism, ed. Anne K. Mellor. Bloomington: Indiana University Press, 1988.

de Groot, Joanna and Sue Morgan. 'Beyond the "Religious Turn"?: Past, Present and Future Perspectives in Gender History'. Gender and History 25.3 (2013).

Demers, Patricia. The World of Hannah More. Lexington, KY: University of Kentucky Press, 1996.

Halsey, Katie. "'Tell Me of Some Booklings": Mary Russell Mitford's Female Literary Networks'. Women's Writing 18.1 (2011).

Hamilton, Elizabeth. Memoirs of Modern Philosophers, ed. Claire Grogan. Peterborough, Ontario: Broadview, 2000.

Horsley, Samuel. The Charge of Samuel Lord Bishop of Rochester, to the Clergy of his Diocese, Delivered at His Second General Visitation, in the Year 1800. London: Robson, 1800.

Jager, Colin. The Book of God: Secularization and Design in the Romantic Era. Philadelphia: University of Pennsylvania Press, 2007.

Kairoff, Claudia Thomas. Anna Seward and the End of the Eighteenth Century. Baltimore: Johns Hopkins University Press, 2012.

King, Kathryn. 'Elizabeth Singer Rowe's Tactical Use of Manuscript and Print', Women's Writing and the Circulation of Ideas: Manuscript Publication in England, 1550-1800, ed. George L. Justice and Nathan Tinker. Cambridge: Cambridge University Press, 2002.

Koretsky, Deanna P. 'Sarah Wesley, British Methodism, and the Feminist Question, Again'. Eighteenth-Century Studies, 46.2, 2013. 
Krueger, Christine. The Reader's Repentance: Women Preachers, Women Writers, and Nineteenth Century Social Discourse. Chicago: University of Chicago Press, 1992.

Lamb, Charles and Mary Lamb. 'Charles Lamb to S. T. Coleridge', The Works of Charles and Mary Lamb, ed. E. V. Lucas. London: Methuen, 1905.

'Letter from Elizabeth Hamilton to Sarah Wesley, Oct. 30, 1801'. MARC. GB 135 DDWF 26/56.

'Letter from Elizabeth Hamilton to Sarah Wesley, Dec. 22, 1802'. MARC. GB 135 DDWF 26/57.

'Letter from Sally Wesley to Unknown'. MARC. John Rylands Library. GB 135 DDWF 14/61.

Levy, Michelle. 'Women and Print Culture, 1750-1830', The History of British Women's Writing, 1750-1830, ed. Jacqueline Labbe. Basingstoke: Palgrave Macmillan, 2010.

Linkin, Harriet Kramer. 'Introduction', Selena: A Scholarly Edition. Burlington, VT: Ashgate, 2012.

-. 'Mary Tighe and the Coterie of British Women Poets', The History of Women's Writing, 1750-1830, ed. Jacqueline M. Labbe. New York: Palgrave Macmillan, 2010.

—. 'Mary Tighe and Literary History: The Making of a Critical Reputation'. Literature Compass 7.7 (2010).

Mack, Phyllis. Heart Religion in the British Enlightenment: Gender and Emotion in Early Methodism. Cambridge: Cambridge University Press, 2008.

Mee, Jon. Romanticism, Enthusiasm, and Regulation: Poetics and the Policing of Culture in the Romantic Period. Oxford: Oxford University Press, 2003.

Mellor, Anne K. Mothers of the Nation: Women's Political Writing in England, 1780-1830. Bloomington: Indiana University Press, 2000.

Moore, Roger E. Jane Austen and the Reformation. Abingdon: Routledge, 2016.

Myers, Mitzi. 'Reform or Ruin: "A Revolution in Female Manners"'. Studies in Eighteenth Century Culture (1982).

Nardin, Jane. 'Hannah More and the Problem of Poverty'. Texas Studies in Literature and Language 43.3 (2001).

Nightingale, Joseph. A Portraiture of Methodism. London: Longman, Hurst, Rees, and Orme, 1807.

'Sarah Wesley to Anna Letitia Barbauld, July 9, 1807', MARC, GB 135 DDWF $14 / 22$.

Stott, Anne. Hannah More: The First Victorian. Oxford: Oxford University Press, 2004.

Taylor, Barbara. 'For the Love of God: Religion and Erotic Imagination in Wollstonecraft's Feminism', Mary Wollstonecraft and 200 Years of Feminisms, ed. Eileen Janes Yeo. New York: New York University Press, 1997.

Wesley Family Series. Box WF4. Frank Baker Collection of Wesleyana and British Methodism. Duke University Libraries.

Wesley, Sarah. 'Aurelia'. WFS, Box WF4, Folder 3, Baker Collection. Duke University Library. 
—. 'The Elopement'. MARC. GB 135 DDWF 14/68/22.

White, Laura Mooneyham. Jane Austen's Anglicanism. Burlington, VT: Ashgate, 2011.

Winckles, Andrew O. 'Pray for the Unworthy Scribbler: Oral, Manuscript, and Print Cultures of Early Methodist Women', After Print: Manuscripts in the Eighteenth Century, ed. Rachael Scarborough King. Philadelphia: University of Pennsylvania Press, Forthcoming.

Yeldham, Charlotte. Maria Spilsbury: Artist and Evangelical. Burlington, VT: Ashgate, 2010. 


\title{
Susanna Watts and Elizabeth Heyrick
}

\author{
Collaborative Campaigning in the Midlands, \\ 1820-34
}

Felicity James and Rebecca Shuttleworth

In the Record Office for Leicestershire, Leicester and Rutland is a large black ledger, heavily worn, of a type which might have been used by some hosiery manufacturer or Leicester shopkeeper. But this ledger is bursting with letters, drawings, poems and ephemera: it is a record not of business transactions but of female connection, creativity and activism in Leicester in the early nineteenth century. Owned by Susanna Watts (c. 1768-1842), it bears witness to her own intellectual interests and to her friendships with other women writers and campaigners. Her closest friend was the activist Elizabeth Heyrick (1769-1831), a member of the influential Coltman family, and together they formed part of an extensive network of other remarkable women including the novelist Catherine Hutton (1756-1846), the composer, pianist and organist Martha Greatorex (1759-1829), and the needlework artist Mary Linwood (1755-1845), as well as others who were clearly influential but who have left less trace of their own individual voices, such as Mary Reid (1769-1839) and Heyrick's sister, Mary Ann Coltman (1778-1871), who collaborated with Heyrick and Watts on an anti-slavery periodical which bears some resemblance to the scrapbook itself. Looking at the productions of such networks provides an insight into the rich culture of provincial women: from the ground-breaking scientific experiments of the Lunar Men to Victorian industrial innovation and social reform, the Midlands have long been recognised as one of the great hubs of Enlightenment and nineteenth-century creativity. Yet the role of women in this male-dominated community still remains to be fully explored. This chapter aims to restore a range of female voices to our understanding of Midlands society, religion, literature and reform, and to trace some threads of connection which bound together provincial society at a key point in history. It also shows some of the tensions and difficulties faced by these women as they conceptualised their activist role in society, examining their participation 
in abolitionist discourse against a larger context of friendship and women's writing in the period.

This group of women is at once extraordinary, and typical. Extraordinary, because of their wide output of campaigning publications, poetry and other literature, and their vigorous intellectual and philanthropic activities. These resonated through England and across the Atlantic, until Lydia Maria Child could write in 1838, thinking back to Heyrick's pamphlet Immediate, not Gradual Abolition of 1824, 'Has not the one idea that rose silently in Elizabeth Heyrick's mind, spread until it has almost become a world's idea?' Yet what this chapter seeks to emphasise is precisely that these women's achievements do not depend on 'one idea' arising silently for an individual, but that they come about through collaboration and conversation. This group of Leicester thinkers is only one node of a larger provincial network of writers, readers, thinkers, and worshippers - typical, in some respects, of the ways in which small female coteries might exert a lasting cultural effect. Kathryn Gleadle has shown how groups of 'radical Unitarians', many with links to the Leicester women, established in the 1830s and 1840s 'essential ideologies and personnel networks which were to determine the feminist movement of the succeeding decades'; Ruth Watts has also demonstrated the remarkable political and social impact of nonconformist women working together, particularly through education. ${ }^{2}$ There has been less attention paid, however, to the literary and creative aspects of such women's networks. Literary criticism has, for so long, been locked in its love-hate relationship with the single (usually male) author that it is only relatively recently that we have begun seriously to look at the complex webs of connections which sustain individual authors and thinkers, especially those inflected by religion, and to move towards an appreciation of sociable creativity. As Gillian Russell and Clara Tuite contend, 'the solitary self has stood for Romanticism for too long'; we need now to appreciate the work that was going on in conversations, in letters, around firesides and dinner tables, in streets and taverns and theatres, in schools and lecture-halls. ${ }^{3}$ Yet even Russell and Tuite's important collection of essays spends a good deal of its time on metropolitan sociability and well-known groupings. Provincial writers - and provincial women, especially - have attracted less attention, and it is only now

${ }^{1}$ Lydia Maria Child to E. Carpenter, 6 September 1838, in Letters of Lydia Maria Child (Boston: Houghton Mifflin, 1883), p. 23.

${ }^{2}$ Kathryn Gleadle, The Early Feminists: Radical Unitarians and the Emergence of the Women's Rights Movement, 1831-51 (New York: St Martin's Press, 1995, $2^{\text {nd }}$ edn. 1998), p. 1; Ruth Watts, Gender, Power and the Unitarians in England, 1760-1860 (London and New York: Routledge, 1998). See also Marjorie Reeves, Female Education and Non-Conformist Culture, 1700-1900 (Leicester: Leicester University Press, 2000).

${ }^{3}$ Gillian Russell and Clara Tuite, eds., Romantic Sociability: Social Networks and Literary Culture in Britain, 1770-1840 (Cambridge: Cambridge University Press, 2002), p. 4. 
that regional and religious nuances are truly starting to be investigated and appreciated. ${ }^{4}$ A close look at the relationship between these Leicester women allows a side-long glimpse of conversations and creative practices in the transitional years from the Enlightenment to the nineteenth century.

The range of these creative practices, including art, needlework, and music, and the achievements of Linwood, Greatorex, and Hutton, are ripe for further research: a wealth of archival material still remains relatively unexamined. In this chapter, however, we will be concentrating primarily on the abolitionist voices of Elizabeth Heyrick and Susanna Watts, whose friendship lies at the heart of the network. Heyrick, 'the foremost female anti-slavery pamphleteer', is probably the best known of the writers, thanks to pamphlets such as Immediate, not Gradual Abolition: Or, An Inquiry Into the Shortest, Safest, and Most Effectual Means of Getting Rid of West Indian Slavery (1824). ${ }^{5}$ This was one of the first and certainly most forceful texts to argue against the contemporary trend of advocating a gradual abolition of slavery as politically and economically expedient; the 'means' for which it argued being a rejection of all slave-grown produce. It was reprinted numerous times within its first year of publication, including in America, attracting widespread attention and reviews; it was discussed in parliament as 'the work of some gentleman' thanks to its fiery insistency. ${ }^{6}$ It formed part of a larger local abolitionist campaign involving Heyrick, Watts, and Heyrick's sister Mary Ann Coltman which in turn had a clear role in shaping the approaches of female anti-slavery organisations. From 1824 onwards, the women canvassed door to door in their Leicester community, persuading households to boycott slave-grown sugar in a revival of ideas first mooted in the late 1780s and early 1790s. Playing on women's perceived social role as consumers and household managers, the group used traditional female responsibilities and concerns to pressure for political change. The sugar boycott was supported by Heyrick's pamphlets, and by a collaborative anti-slavery periodical, The Humming Bird; or, Morsels of Information, on the Subject of Slavery, which they produced from December 1824. This brought together essays, illustrations and poetry, and adopted an editorial tone of intellectual, as well as moral authority. This three-pronged approach - advocacy of community canvassing to boycott slave grown goods, collaborative periodical publication, and determined immediatist stance supported by pamphleteering

${ }^{4}$ For example, in the remarkable collection of papers Nonconformist Women Writers, 1720-1840, ed. Tim Whelan, 8 vols. (London: Pickering \& Chatto, 2011).

5 Clare Midgley, Women Against Slavery. The British Campaigns 1780-1870 (London and New York: Routledge, 1992), p. 75.

${ }^{6}$ For more discussion of the national, and international, impact of the pamphlet and its effect on other abolitionist societies, see Midgley, Women Against Slavery, pp. 103-7, and the anonymously authored A Brief Sketch of the Life and Labours of Mrs Elizabeth Heyrick (Leicester: Crossley and Clarke, 1862), p. 10. 
- was to have a lasting effect on the landscape of the anti-slavery movement, locally, nationally, and internationally, since their reputation spread across the Atlantic. The women's abolitionist work, moreover, formed only one strand of their activism. Together, Heyrick and Watts campaigned for a range of animal and human rights, speaking out on behalf of those marginalized in society the poor, the elderly, the imprisoned, the ill-paid.

Elizabeth Heyrick's family context, as a member of the Dissenting manufacturing clan, the Coltmans, rooted her in a particular intellectual and religious culture. Yet she also rebelled against family views. Her marriage in 1789 to John Heyrick, part of a leading local Anglican family, does not seem to have been welcomed by her relatives: it appears to have been a tempestuous love match, 'the work of a moment'.' The two clearly had shared sympathies - John Heyrick's book of poetry, First Flights (1797), pays tribute to her abolitionism and her concern for animals as well as her friendships, with poems dedicated to Susanna Watts and Mary Linwood - but Heyrick was a possessive husband who isolated her from her family, who complained of his 'reckless self-indulgence [...] his capricious violence and suspicion'. ${ }^{8}$ Nevertheless, on his unexpected death in 1797 while she was at church, Elizabeth Heyrick was overwhelmed by grief, and sought comfort in religion. This gradually led to a conversion to Quakerism, and to her development of a public, reformist voice. She became a skilled and prolific pamphleteer, and although it is usually her anti-slavery works which are remembered, these should be contextualized as part of a broad span of works drawing attention to various social injustices and cruelties: bull-baiting, labour rights, the difficulties faced by Leicester's framework knitters, and the Poor Laws. Her identity as 'radical Quaker' and pamphleteer has been ably discussed by Kenneth Corfield and more recently in the context of women's anti-slavery campaigning by Clare Midgley, although she has still not achieved the full recognition she deserves. ${ }^{9}$ She has, for example, often been conflated with her acquaintance, Elizabeth Coltman, also from Leicester, the author of educational works Plain Tales (1799), Instructive Hints in Easy Lessons for Children (1806) and Familiar Letters Addressed to

7 Catherine Hutton, 'Hasty Sketch of the Coltman Family' (1802). Record Office for Leicestershire, Leicester and Rutland, MS 15D57/387.

${ }^{8}$ Samuel Coltman, Time's Stepping Stones - Or Some Memorials of Four Generations of a Family - by an Octogenarian Member of the Same (1852). Record Office for Leicestershire, Leicester and Rutland, MS Misc. 1153, p. 171.

9 Kenneth Corfield, 'Elizabeth Heyrick: Radical Quaker', in Gail Malmgreen (ed.), Religion in the Lives of English Women, 1760-1930 (London: Croom Helm, 1986), pp. 41-67; Clare Midgley, 'The Dissenting Voice of Elizabeth Heyrick: An exploration of the Links between Gender, Religious Dissent and Anti-Slavery Radicalism', in Women, Dissent and Anti-Slavery in Britain and America, 1790-1865, ed. Elizabeth Clapp and Julie Roy Jeffrey (Oxford: Oxford University Press, 2011), pp. 88-110. 
Children and Young Persons of the Middle Ranks (1811), as well as an anti-war tract. These have long been catalogued as Heyrick's work, and have led to some confusion about, for example, her views on gender equality. ${ }^{10}$ She ought, too, to be seen in the context of her friendship with Susanna Watts, to whom less critical attention has been paid, with some exceptions such as the work of local historian Shirley Aucott, and a detailed discussion of animal rights and national identity by Moira Ferguson, who shows how closely Heyrick, her sister Mary Ann, and Watts worked together. ${ }^{11}$

Prior to her work on abolition, Heyrick published a variety of pamphlets considering forms of animal cruelty, such as A Christmas Box for the Advocates of Bull-Baiting (1809), Bull-Baiting: A Village Dialogue between Tom Brown and John Simms (1809) and Cursory Remarks on the Evil Tendency of Unrestrained Cruelty, particularly on that practised in Smithfield Market (1823). It is recorded that whilst staying in the Derbyshire village of Bonsall she bought a bull destined to be baited, and then hid it the parlour of her hosts to protect it from the furious villagers. Meanwhile, Susanna Watts explored the treatment of animals in equally vivid, if more fanciful ways. The Insects in Council (1828), Watts's long poem from the perspective of insects including gnats, dragonflies, and a praying mantis, footnotes Heyrick's pamphlet on the 'barbarities of Smithfield', as she shows the insects pleading for their freedom from 'slav'ry and grief' at the hands of man, 'the dread boiling water or poisonous pin'. ${ }^{12}$ The women's humanitarian interests thus echo and develop one another in collaborative exchange. Both women were engaged in a larger programme of social, economic and political analysis and commentary, informed by their religious convictions - and the intellectual and social connections of their Midlands background.

The object with which we began, Watts's scrapbook, provides a nice illustration of the ways in which different aspects of the women's lives and works come together, an artefact which reflects the women's community and wider network, as well as the range and scope of their cultural activity. It begins with a translation of Tasso, which Watts undertook as a commercial proposition, hoping to make an income from it because of difficult financial circumstances.

${ }^{10}$ See Tim Whelan's discussion of this persistent misattribution in Other British Voices: Women, Poetry, and Religion, 1766-1840 (New York: Palgrave Macmillan, 2015), p. 185; p. 233.

${ }^{11}$ Shirley Aucott, Elizabeth Heyrick 1769 to 1831: The Leicester Quaker Who Demanded the Immediate Emancipation of Slaves in the British Colonies (Leicester: Shirley Aucott, 2007); Susanna Watts (1768 to 1842): Author of Leicester's First Guide, Abolitionist and Bluestocking (Leicester: Shirley Aucott, 2004). Moira Ferguson, Animal Advocacy and Englishwomen, 1780-1900: Patriots, Nation, and Empire (Ann Arbor: University of Michigan Press, 1998).

${ }_{12}$ Susanna Watts, The Insects in Council, Addressed to Entomologists, with other Poems (London and Leicester: Hurst and A. Cockshaw, 1828), pp. 20-21. 
Her father died when she was an infant, the family home had to be sold to provide a bare annuity, and she supported herself and her mother through her writing: she may also have assisted with teaching, and she experimented with pictures in feathers and needlework alongside Mary Linwood. Although the Tasso translation was never published, it demonstrates her self-taught skill in languages; her other works include Chinese Maxims. Translated from The Oeconomy of Human Life, into Heroic Verse (1784), and The Wonderful Travels of Prince Fan-Feredin, in the Country of Arcadia (1799), collections of hymns, poems, and works for children. She had a keen interest in local history and wrote the first guidebook to Leicester in 1804, showing extensive knowledge of the settlement's development from Roman times and detailing its changes and expansion in the early decades of the nineteenth century.

The scrapbook literally pieces together these different intellectual and artistic endeavours, along with the friendships of Susanna Watts. It begins with a biographical introduction to Watts added to the book by a subsequent owner, Clara Parkes, in 1865, which emphasises both her individual achievements and the way these were embedded in a context of friendly relationships with other women. Parkes begins by detailing Watts's prowess in different forms of arts - a medal won for 'an ingenious type of needle-work, in hair'; her invention of 'curious and beautiful' landscapes in feathers; her poetry and translations - before moving on to her campaigning work. Both she and 'her friend Elizabeth Heyrick, were indefatigable in the use of their pens \& their influence on the side of philanthropy', and Parkes records the importance of their legacy, and the illumination of their names in Leicester in the abolition celebrations of 1834. Parkes' account concludes with another tribute to female friendship, the importance of 'her attachment to Ann Coltman was life-long \& invariable, \& was most warmly reciprocated'. It is to this particular friendship that the book owes its survival, since it was bequeathed to Coltman, who 'in her turn, bequeaths with every kind wish and much affection, to her great great niece, Clara Parkes.'13 The dedication sums up several important points about the volume: it balances Watts's more traditionally feminine and domestic achievements - needlework, feather landscapes - against her role as outspoken, publicly acknowledged activist, and makes clear, above all, that her work is rooted in female networks.

The rest of the volume bears out the importance of such networks, and unites different aspects of Watts's life and works. We move between rhyming games - 'subject and rhyme given by J. Coltman, senr. Filled up impromptu by Miss Watts, at the age of 16 or 17 ' - which demonstrate the sociability of Watts's creative circle, careful pen and ink drawings of flowers and butterflies

${ }^{13}$ Susanna Watts, Scrapbook, The Record Office of Leicestershire, Leicester and Rutland, Rare Books, L. A. Watts, p. 1. 
which would later be included in Watts's published works such as The Insects in Council, penny portraits of famous men and women, excerpts from the work of Hannah More and others, advertisements, ephemera ranging from an illustrated 'Hindi Primer', railway tickets, and a flyer for an exhibition at Mr. Gee's Boot Maker: 'The Industrious Fleas' drawing a 'First-Rate Man of War'. There are gift poems to other members of the group such as Mrs William Heyrick and Mary Frewen - 'To Miss Frewen - With a box of patent pins - whose heads \& points are all one piece' - and poems of friendship such as this, addressed to Susanna Watts by Martha Greatorex:

\author{
My dear Miss Watts \\ Though it's our lots \\ Oft times to separate be: \\ Yet I and you, \\ (It is most true) \\ Can never disagree. (p. 181)
}

Other testimonies to the wider world of Dissenting female creativity include a transcription of a poem by Barbauld's niece, Lucy Aikin, 'Homage to Mary Linwood. On Miss Linwood's Gallery of Pictures Worked in Worsted', and a piece on Cowper's garden by Jane Taylor of Ongar. In the midst of this miscellaneous material come artefacts relating to Watts's abolitionist work: female anti-slavery society petitions, and illustrated cards still brightly coloured in violet and green carrying poems, 'The Slave's Address' and 'The Captive Lion'. Such publications and cards, along with the trace of other women's handwriting, and transcriptions of each other's writing, make clear that this scrapbook is a semi-public document, circulated among family and friends and bearing witness to their shared political and creative interests.

We can therefore see it as analogous to the women's collaboratively produced anti-slavery periodical, The Humming Bird. When published in volume form its opening statement makes reference to the support of friends:

We cannot permit the Humming Bird to take wing, and wander beyond the rather narrow circle to which it has hitherto been confined, without expressing our gratitude to those friends who have listened to its unpretending song with indulgent attention. ${ }^{14}$

Although described as an 'unpretending song' the periodical advertises its intellectual inheritance. The women's chosen editorial personas were an 'ancient

14 'Preface', The Humming Bird; or, Morsels of Information, on the Subject of Slavery (London: A. Cockshaw, 1825), pp. iii-v, (p. iii). 
sisterhood' comprised of Truth, Common Sense and Philanthropy, who were in possession of mythical items from classical literature: 'the very spear by a touch of which the Seraph Ithuriel discovered Satan', 'the clue of Ariadne' and 'the very same piece of tapestry which, by the magic art of the Fairy Pari Banou, was bestowed on Prince Houssain' (p. 3). The periodical strikingly deploys contemporary accounts of slavery, combined with an impressive knowledge of classical, historical, scriptural and philosophical texts. Throughout, the theme of friendship continues as an important strand in its abolitionist message: it not only makes an appeal for friendship to be extended to slaves, but is also the record of a group of friends - mainly women - working together. The 'Friendly Reader' is told about the periodical stemming from a 'small party of Friends being in earnest conversation upon the subject of the Slave Trade' (p. 4). As in the scrapbook, the conversation not only includes abolitionist material but also poems by the Leicester circle, historical, geographical and botanical information, extracts from writers such as Elizabeth Bentley and Hannah More, as well as essays bemoaning animal cruelty, and the treatment of the poor. Friendship itself is scrutinised in an essay, 'Thoughts on Friendship', which closes by linking it directly to Christ's tenderness, so that the women's own philanthropic activities - and their publication strategy - are given a form of divine authority.

Both scrapbook and periodical thus bear out recent work rethinking the nature of political action in the early years of the nineteenth century: as Amanda Vickery has argued, we need to extend our concept of the public political sphere 'to include the supposedly "private" world of family connections and friendship networks - within which political ideas were debated and new social practices played out. ${ }^{15}$ Alongside this interest in breaking down categories of public and private political debate, recent criticism has begun to pay closer attention, in Vickery's words, to the wider 'contexts both intellectual and familial' which gave rise to female activism (p. 3). The intermingling of different items in both scrapbook and periodical vividly makes this point, showing how the public voice of abolitionism arose within a larger context of private friendship and shared creativity. Moving between the homely sociability of a rhyming contest between friends and an anti-slavery petition or pamphlet also underlines the point eloquently made by Kathryn Gleadle that, in thinking about women's networks and women's achievements in this period, we need to consider the intersection of domestic and political agency, 'the home too could function in terms of political space'. ${ }^{16}$

${ }^{15}$ Amanda Vickery, ed. Women, Privilege, and Power: British Politics, 1750 to the Present (Stanford: Stanford University Press, 2001), p. 3.

${ }^{16}$ Kathryn Gleadle, 'British Women and Radical Politics in the Late Nonconformist Enlightenment, c.1780-1830', in Vickery, Women, Privilege and Power, pp. 123-51 (p. 126). 
It could also, of course, be a contested one. The scrapbook records a moment of frustration as the women experienced tensions between these public and private roles, and friction even within their own local communities. A manuscript poem in the volume in Susanna Watts's hand voices anger at the expectations others projected onto them:

On a Gentleman saying that,

Some ladies, who were zealous in the

Anti-Slavery Cause, were brazen faced.

Thanks for your thought - it seems to say.

When ladies walk in Duty's way,

They should wear arms of proof;

To blunt the shafts of manly wit -

To ward off censure's galling

And keep reproach aloof: -

And when a righteous cause demands

The labour of their hearts and hands,

Right onward they must pass,

Cas'd in strong armour, for the field -

With casque and corselet, spear and shield,

Invulnerable brass. (p. 303)

The poem may be seen as a complex response to the circle around William Wilberforce, with whom the women were connected through a mesh of local links. Leicester MP, Thomas Babington, elected on an anti-slavery platform, was an intimate friend of Wilberforce, who often spent time at Babington's Leicestershire home, Rothley Temple. A watercolour of Rothley is pasted into Watts's scrapbook, along with an image of Wilberforce, and the women's familial links with the Babington circle of abolitionists is demonstrated by the list of Officers of the Leicester Auxiliary Anti-slavery Society, printed in their first publication An Address on the State of Slavery in the West India Islands. Headed by Babington, the society committee includes Elizabeth Heyrick's family members, her brother, John Coltman and brother-in-law, William Heyrick. Crucially, however, no women are listed. For despite their shared abolitionist aims, the approach put forward by Leicester women differed considerably from that put forward by Wilberforce and Babington. The Wilberforce circle advocated a gradualist course of action, supported by the pressure group the Society for the Mitigation and Gradual Abolition of Slavery and its local offshoots like the Leicester Auxiliary Anti-slavery Society. The Leicester Address summarises this wary position, stressing that 'we are yet far from proposing a sudden revolution': 'we should deprecate 
an immediate emancipation almost as much as the planters themselves. ${ }^{17}$ The women, however, were far more 'zealous', to borrow Watts's description, calling for immediate action at home and abroad, and taking matters into their own hands through their canvassing and boycotting activities. Set alongside Babington's advocacy of a 'slow and gradual cure', supported by her own relatives, Heyrick's rebuttal of the 'senseless cry of gradual emancipation' in Immediate, not Gradual, Abolition appears even more striking: 'this GRADUAL abolition,' she thunders, 'has been the grand marplot of human virtue and happiness; - the very master-piece of satanic policy'. ${ }^{18}$ It was an extraordinarily bold move for Heyrick to set herself against the policies of the revered Wilberforce, which are here cast not as saintly, but as 'satanic' - a position little short of heresy in abolitionist circles.

The Leicester women's activities caused Wilberforce considerable uneasiness. In such direct action, he worried in a letter to Thomas Babington, women were endangering their character - and the cause:

All private exertions for such an object become their character, but for ladies to meet, to publish, to go from house to house stirring up petitions, - these appear to me proceedings unsuited to the female character as delineated in scripture. And though we should limit the interference of our ladies to the cause of justice and humanity, I fear its tendency would be to mix them in all the multiform warfare of political life. ${ }^{19}$

Wilberforce's disapproval, and Watts's defence of female campaigning, points to an underlying tension in the contemporary evolution of women's place in public and political spheres that was brought into sharp relief by the rapid expansion of British women's involvement in the campaign for abolition. Wilberforce's Evangelical Anglican Clapham Sect, which counted among its members conservative female writers such as Hannah More, had been for some decades crafting a complex social identity for women which anticipated the Victorian emphasis on idealised, angelic domesticity. As discourse on social morality began to invoke home and family as an essential component of an upright Christian nation, women's movements between the domestic, social and political spheres required careful navigation. In her 1799 text Strictures

${ }^{17}$ Leicester Auxiliary Anti-slavery Society, An Address on the State of Slavery in the West India Islands. (London: Hamilton and Leicester: T. Combe, 1824), pp. 20-21.

${ }^{18}$ Elizabeth Heyrick, Immediate, not Gradual Abolition: Or, An Inquiry Into the Shortest, Safest, and Most Effectual Means of Getting Rid of West Indian Slavery (London: Hatchard, 1824), p. 9.

${ }^{19}$ Letter from William Wilberforce to Thomas Babington, 31 January 1826, cited in Robert Isaac Wilberforce and Samuel Wilberforce, The Life of William Wilberforce by His Sons, 5 vols. (London: John Murray, 1839), V: pp. 264-5. 
on the Modern System of Female Education, Hannah More simultaneously denigrated and elevated a domestic ideal of Christian womanhood:

Whatever inferiority may be attached to woman from the slighter frame of her body, the more circumscribed powers of her mind, from a less systematic education, and from the subordinate station she is called to fill in life; there is one great and leading circumstance which raises her importance, and even establishes her equality. Christianity has exalted woman to true and undisputed dignity ... Their hearts are naturally soft and flexible, open to impressions of love and gratitude; their feelings tender and lively: all these are favourable to the cultivation of a devotional spirit. ${ }^{20}$

Thus, from More's perspective, a woman safely ensconced within the domestic sphere, and so uncorrupted by the numerous vices found in the public, might be able to act as an inspirational Christian influence upon her family, to temper their interactions with public and political life.

But how far should women's own intervention in political activity go? As the second wave of anti-slavery campaigns began to roll out across Britain, many women felt the cause fell well within their jurisdiction of moral improvement for the nation through Christian empathy and assistance for the oppressed. Male leaders of the movement, however, disagreed. With its significant consequences for the commercial wealth and success of the nation, the question of slavery could not, felt leaders such as Wilberforce, be publically engaged with by women without an inappropriate level of involvement with the political sphere. Although women were permitted to subscribe to male anti-slavery societies as financial donors, as the list of officers of the Leicester Auxiliary Anti-Slavery Society demonstrates, they were not given any positions of influence within the campaign. Barred from direct involvement with the official face of abolition, women across Britain began to seek alternative methods to contribute to the cause, and in doing so, co-opted the concept of the spiritually and morally superior nature of femininity to justify their place within a public and political campaign, rather than discourage it. As we see from Wilberforce's comments, he was anxious that involvement even in a Christian cause might conflict with the 'female character as delineated in Scripture'; abolitionist women responded by showing how the female character might be particularly suited to such a cause, and adapting female activities to accommodate their activism. The publications of female anti-slavery societies emphasised women's religious

${ }^{20}$ Hannah More, Strictures on the Modern System of Female Education, With a View of the Principles and Conduct Prevalent Among Women of Rank and Fortune (London: T. Cadell Junior and W. Davies, 1799), p. 31. 
sensibilities and the heightened female capacity for compassion and empathy which More had described; they also used their domestic influence as a way to gain ground in the campaign. Balancing domesticity, feminine sympathy and activism could be difficult, and in the publications of Female Anti-Slavery Societies such as Birmingham and Sheffield we see some complicated rhetorical negotiations as women try to work out how best to convey their abolitionist message. It is clear from quotations of Heyrick's work and allusions to the Leicester women's practices of publication, canvassing, and boycotting that they exerted a profound influence on the Birmingham and Sheffield female activists, although the ways in which they conduct their own campaigns can vary slightly but significantly from the Heyrick circle.

While it made no specific reference to her gender, Heyrick's Immediate, not Gradual Abolition had argued for a rejection of gradual abolition on the grounds of Christian morality, and such emphasis on the Christian imperative would become a characteristic rhetorical strategy of female anti-slavery societies. In 1826 the first report of the Birmingham Female Anti-Slavery Society opened with an explanation of its members' motivation. They expressed particular sympathy 'for the degraded condition of their own sex' and therefore 'determined to endeavour to awaken (at least in the bosom of English women) a deep and lasting compassion, not only for the bodily sufferings of female Slaves, but for their moral degradation':

Such Slavery as that which now exists in our Colonies, should have the prayers of all Christians, and the best exertions of every Briton, united against it, that 'they who name the name of Christ may depart from this iniquity'.

As the collective published voices of women's anti-slavery societies began to appear as the movement spread across Britain, religious morality such as this was at the forefront of their rhetoric, portraying slavery as an essentially moral issue and a mortal sin. Whilst many male anti-slavery societies drew on religious rhetoric in their arguments, it was most often tempered by an awareness of economic and political practicalities in campaigning for its abolition. Female societies, however, were, like Heyrick, far more disposed to view the matter as one of such moral gravity that religious faith could not permit a policy of gradual abolition.

In response to Heyrick's Immediate, Not Gradual, Abolition pamphlet, members of the Sheffield Female Anti-Slavery Society justified their decision

${ }^{21}$ The First Report of the Female Society, for Birmingham, West Bromwich, Wednesbury, Walsall, and Their Respective Neighbourhoods, For the Relief of British Negro Slaves (Birmingham: Richard Peart, 1826) p. 3. 
to adopt her stance for immediate abolition by presenting it as a matter of divine command:

We ought to obey God rather than Man. Confidence here is not at variance with humanity. On principles like these, the simple need not fear to confront the sage; nor a female society to take their stand against the united wisdom of this world. ${ }^{22}$

This appeal to faith ran alongside an emphasis on women's greater capacity for compassion, particularly for the plight of enslaved women and children. In their annual reports the Sheffield Female Anti-Slavery Society, for example, repeatedly invoked as one of their resolutions their eagerness to see a time when the lash would no longer be used 'to lacerate the persons of helpless females', and 'when every negro mother, protected by British laws, shall press a free-born infant to her bosom. ${ }^{23}$ The language of this resolution draws on a long history of sentimental abolitionist material, and fitted much more closely into conventional expectations of femininity, reframed to meet the ends of the immediatist cause. Similarly, existing standard female charitable activities were adopted by women abolitionists so that traditional expressions of domesticity could be used for political purposes. As the Sheffield Female Anti-Slavery Society reports in 1825 , 'upwards of fourteen hundred pamphlets, tracts, \&c. have been distributed [...] besides the sale of two hundred and seventy-eight work bags, filled with tracts, with an engraving suited to the subject' (p. 1). The sewing of work-bags is a particularly telling example of the ways in which women abolitionists could negotiate boundaries, linking 'the "private" sphere of domestic work with the "public" sphere of campaigning' (Midgley, Women Against Slavery, p. 57). Extracts on the sufferings of slaves were hidden within the interior of the work bags, to be found after purchase and so disseminate this evidence to a wide and potentially unsuspecting audience: an impeccably domestic activity thus concealing a confrontational approach.

Door to door canvassing - as practised by Heyrick, Watts and Coltman also became one of the primary activities of many societies, but it was carefully framed as 'visiting', a far more sociable and acceptable activity for women. In society reports it was given very little space in the description of their activities, which could devote many pages to sentimental outpourings of sympathy for female slaves, but rarely gave more than a paragraph to the practice of 'visiting'. The second report for the Birmingham society acknowledged that:

\footnotetext{
${ }^{22}$ Report of the Sheffield Female Anti-Slavery Society (Sheffield: J. Blackwell, 1827), p. 10.

${ }^{23}$ Report of the Sheffield Female Anti-Slavery Society (Sheffield: 1825), p. 1; Report of the Sheffield Female Anti-Slavery Society, (Sheffield: 1827), p. 13.
} 
The influence of females in the minor departments (as they are usually deemed), of household affairs is generally such that it rests with them to determine whether the luxuries indulged in, and the conveniences enjoyed, shall come to them from the employer of free men, or from the oppressors of British Slaves. When the preference is given to the latter, we see, therefore, with whom the responsibility must mainly rest. Pleasing accounts have been received from the Visitors who recommend Free Labour Produce in the districts they have undertaken for this purpose. More than half the town of Birmingham has been visited, house by house; and efforts have been made in many places in the neighbourhood to awaken the attention of the inhabitants to the same important subject. ${ }^{24}$

That more than half the town of Birmingham was visited implies a considerable undertaking, but it is noticeable that the report makes very little of it, perhaps choosing not to draw too much attention to one of the most controversial activities of the women's societies.

Thus, Heyrick and Watts's pioneering work in organising community boycotts of slave grown produce, canvassing, and disseminating information relating to the treatment of slaves was adopted and continued throughout the wider network of female societies, but not always in the same direct ways that the Leicester women had employed. The difference is illustrated by the careful selection of the works of Heyrick and Watts which appear in the reports of the central Birmingham Ladies' Anti-Slavery Society, of which they were members as representatives of the Leicester branch of this network. Only a handful of members have individual pieces included within the reports, suggesting the high level of influence the women enjoyed within the movement. Yet the pieces chosen are not necessarily representative of the complete outlook of the two women. The first report for the Birmingham Society, published in 1826, was concluded with an extract from one of Heyrick's less well known pamphlets Letters on the Prompt Extinction of British Colonial Slavery, with an introduction that lauded her contribution to the movement:

The Committee cannot more properly close this Report than in the language, slightly varied, of a female writer who is one of the most powerful, and consistent, advocate of our enslaved fellow-subjects. The Author of 'Letters on the Prompt Extinction of British Colonial Slavery, with Thoughts on Compensation'. ${ }^{25}$

${ }^{24}$ The Second Report of the Female Society for the Relief of British Negro Slaves (Birmingham: 1826), p. 14.

25 The First Report of the Female Society, for Birmingham, West Bromwich, Wednesbury, 
Heyrick is represented not by her most famous and influential work, but by one that places an unusual level of emphasis on divine authority in comparison to her other writings. Addressed to different bodies of people connected with the Abolitionist movement, including male leaders, the wider 'Christian public' and the clergy, it broadens and extends her appeals to individual responsibility, beginning with although not limited to abstention from slave-grown produce. Other suggestions include a call for ministers across denominations, not simply Dissenting preachers, to guide their congregations in abolitionist thinking. The work is as outspoken as Immediate, not Gradual Abolition, beginning by paying homage to the 'great leaders of the AntiSlavery Society' but going on to condemn their continued gradualist approach: 'this pusillanimous proposition is operating like a powerful opiate on our feelings and principles; - it is neutralizing our sympathy, palsying our exertion, and benumbing our charity. ${ }^{26}$ It will in time, she predicts, corrupt the male leaders of the Anti-Slavery societies themselves, and she explicitly attacks 'the mysterious incongruity in the language and conduct of the Gradual Abolitionists' which justifies her 'warmth of remonstrance' (p. 6). This warmth is lacking, however, from the extract chosen for inclusion in the report, which does not pass judgement on the male abolitionists, and puts its case in Scriptural, rather than personal, terms:

"Let this people go," - is the authoritative language of the great Parent of the Universe, to all who have ears to hear the voice of reason, of conscience, of revelation;- - to all who keep aloof from the confused Babel of sordid interest and political expediency [...] in the case of the poor Negro, the command is not less intelligible in a Christian's ear, because conveyed by the spirit, instead of the Divine injunction. ${ }^{27}$

Whether the extract was selected by Heyrick herself or the society committee, it is evidently intended to support their collective image as acting on divine authority. In shortening the extract, we also lose a graphic description of the cruelty of the merchant 'who stamps brand marks into [the slave's] flesh with hot irons [...] chains and flogs him without mercy', and whose sins are continued by the consumer of slave-grown produce (Heyrick, Letters, p. 94). Instead, the extract as presented is an explicitly religious address, dictated by 'Divine injunction', and as such indicates the ways in which Heyrick's

Walsall, and Their Respective Neighbourhoods, For the Relief of British Negro Slaves (Birmingham: 1826), p. 12.

${ }^{26}$ Elizabeth Heyrick, Letters on the Necessity of a Prompt Extinction of British Colonial Slavery: Chiefly Addressed to the More Influential Classes, to which are Added, Thoughts on Compensation (London and Leicester: 1826), p. 1; p. 5.

27 The First Report of the Female Society, for Birmingham, West Bromwich, Wednesbury, Walsall, and Their Respective Neighbourhoods, p. 12. 
outspoken political voice could be toned down as it was transmitted in different contexts. Similarly, the poem by Susanna Watts used to head the fourth report in 1828 is an expression of feminine sympathy, as British ladies are encouraged to identify with slave mothers:

\author{
THE SLAVE'S ADDRESS TO BRITISH LADIES. \\ Natives of a land of glory, \\ Daughters of the good and brave, \\ Hear the injured Negro's story, \\ Hear, and help the kneeling Slave. \\ Think, how nought but death can sever \\ Your lov'd children from your hold, \\ Still alive - but lost for ever \\ Ours are parted, bought and sold! \\ Seize, then, ev'ry favouring season \\ Scorning censure or applause; \\ JUSTICE, TRUTH, RELIGION, REASON, \\ Are your LEADERS in our cause! \\ Follow! - faithful, firm, confiding, \\ Spread our wrongs from shore to shore; \\ Mercy's God your efforts guiding, \\ Slavery shall be known no more. ${ }^{28}$
}

Both pieces are by Heyrick and Watts - but they are not quite the Heyrick and Watts who emerge in the scrapbook poem 'On a Gentleman saying that, Some ladies, who were zealous in the Anti-Slavery Cause, were brazen faced'. In that poem, albeit only circulated in manuscript, it is not female capacity for sympathy, nor women's heightened religious sensibilities, which are emphasised. Instead, their 'brazen' aspects become a source of strength, an armour-plating which can protect them in Wilberforce's 'warfare of political life'.

How can we account for this bolder, 'brazen', and more combative approach adopted by Heyrick and Watts? One answer might be to turn back to the specific context indicated by the scrapbook itself: a local, intellectual female friendship group, informed both by wider interest in the arts and by religious enquiry, operating within - and made possible by - a developing industrial economy. Close attention to the precise details of such local networks helps us to understand the nuances of gender in practice, and to understand variations in women's literary, political, or religious outlooks even when these might

${ }_{28}$ The Fourth Report of the Female Society for Birmingham, West Bromwich, Wednesbury, Walsall, and their Respective Neighbourhoods, for the Relief of British Negro Slaves (Birmingham: 1828), p. 1. 
appear to be similar. As Alison Twells has demonstrated in an exploration of Congregationalist women in Sheffield and Baptist circles in Wiltshire, female anti-slavery commitments were 'put into practice in the context of local religious cultures, shaped by immediate circumstances and by wider denominational networks.' ${ }^{29}$ Alongside this argument for 'a deeper understanding of local denominational cultures' we would add that women's friendships, as well as their familial and regional connections, also need to be kept in mind, as these can help both in strengthening faith and in moving beyond denominational boundaries to create a hybrid approach. In the case of Heyrick and Watts, we need to think about the Dissenting culture of the East Midlands at the turn of the century, and a particular atmosphere of intellectual discussion, reflection, and self-examination embodied in the work of the women. To understand their writings we need to place them more precisely in their family, social and religious context.

The Leicester of Heyrick and Watts' youth, in the later eighteenth and early nineteenth centuries, was a city on the move: in 1789 it could still be described as a country town, 'not yet grown far beyond its medieval limits', but the subsequent decades would see rapid expansion, focused on its hosiery trade. ${ }^{30}$ Heyrick's father, John Coltman (1727-1808) was a leading hosiery manufacturer in the city - 'the most outstanding entrepreneur in Leicester during the late eighteenth century' - and an intriguing figure, 'not only', as David Wykes puts it, was he 'an enterprising and active businessman, but was engaged in scientific and philosophical enquiry, antiquarian study and political reform. ${ }^{31}$ This provided the young women of the family circle with a particular intellectual background, which is outlined in a number of papers preserved, along with Watts's scrapbook, in the local record office, including a lengthy memoir by Heyrick's brother, Samuel Coltman, Time's Stepping Stones - Or Some Memorials of Four Generations of a Family - by an Octogenarian Member of the Same. ${ }^{32}$ There are also published accounts of the family by close acquaintances William Gardiner and Catherine Hutton, and Hutton's cousin Catherine Hutton Beale. Such material is crucial in understanding the background for the women involved in this network, not simply Coltman's daughters, Elizabeth

${ }^{29}$ Alison Twells, “We Ought to Obey God Rather Than Man”: Women, Anti-Slavery and Nonconformist Religious Culture', in Women, Dissent and Anti-Slavery, ed. Clapp and Jeffrey, pp. 66-87 (p. 68).

30 A. Temple Patterson, Radical Leicester. A History of Leicester 1780-1850 (Leicester: University College Leicester, 1954), gives an account of the industrial and political growth of the city.

${ }^{31}$ David L. Wykes, 'The reluctant businessman: John Coltman of St Nicholas Street, Leicester, 1727-1808', Transactions of the Leicestershire Archaeological and Historical Society (1995), pp. 71-85 (p. 85; p. 71).

32 Samuel Coltman, Time's Stepping Stones, p. 17. 
and Mary Ann, but also their friends, since Susanna Watts, Mary Reid and Mary Linwood, among others, were clearly intimates of the family, and often appear in the accounts. Watts, for example, is described as 'Sister Susan' by the Coltman family, and such items in the scrapbook as the rhyming games set by John Coltman senior for Watts show her fully taking part in Coltman family life. ${ }^{33}$ Mary Reid, meanwhile, appears to have considered marriage to John Coltman's son, John junior, at one point. ${ }^{34}$

Faith was of central importance to the Coltman family. Like so many of the Midlands industrialists, they were Nonconformist, worshipping at the Great Meeting House in Leicester, at that time a Presbyterian chapel, although it would later become Unitarian. As indicated by this change, characteristic of such institutions at the turn of the century, Nonconformist belief is difficult to define categorically, and even congregations of the same sect could often differ in practice and precise belief. The central factor of the kind of Rational Dissent the Coltman circle would have experienced at the Great Meeting, however, was an emphasis on the signal importance of individual enquiry, on questioning oneself and others. To be a Dissenter, moreover, was not simply a religious identity: it connected individuals to a larger cultural, intellectual, educational and business network throughout the country, and indeed across the Atlantic, since many Nonconformists emigrated through the later eighteenth century. John Coltman illustrates this: the connections he made in his years studying at the Dissenting Academy in Kibworth in Leicestershire under John Aikin Senior, father of Anna Laetitia Barbauld and friend of Joseph Priestley, not only connected him to prominent industrialists elsewhere in England, but also directed his political sympathies towards radical causes. Well before his daughters and their friends set out on their own abolition campaign, Coltman was a 'warm friend to civil and religious liberty', sympathetic to the American and French Revolutions, opposed to the Anglo-French war, encouraging emigration to America, and supporting the foundation of the colony for former slaves at Sierra Leone. ${ }^{35}$ His experience at Kibworth also established his life-long scholarship, intellectual enquiry and interest in classical studies and archaeology, including coin collecting. Coltman's knowledge of local history and archaeology may well have informed Susanna Watts's guide to Leicester, which discusses in detail the Roman origins of the city, and relics including mosaics and coins, and the philosophical and classical knowledge on show in the Humming Bird

\footnotetext{
${ }^{33}$ Catherine Hutton Beale, Catherine Hutton and her Friends (Birmingham: Cornish Brothers, 1895), p. 159.

${ }^{34}$ See Samuel Coltman, Time's Stepping Stones, and discussion by Whelan, Other Voices, p. 164.

35 William Gardiner, Music and Friends: Or, Pleasant Recollections of a Dilettante, 2 vols. (London and Leicester: Longmans, 1838), I: p. 61.
} 
should be seen as, in part, a reflection of the intellectual interests fostered at Kibworth and passed on, through Coltman and his friends, to their wider female circle. ${ }^{36}$

Although Leicester could not quite rival the intellectual environment fostered by Brimingham's Lunar Society, it is clear Elizabeth Heyrick was brought up in a highly educated, Dissenting family, who were well acquainted with leading radical Unitarians such as Priestley. Such an important intellectual and cultural legacy needs to be taken into account when considering the development of Heyrick, Watts and their circle. The complex position of women in Rational Dissenting society also needs to be considered, beginning with the relationship between Coltman and his wife, Elizabeth, née Cartwright. She seems to have been his intellectual equal, highly educated and devout, with family connections to literati including Robert Dodsley, Joseph Spence, and William Shenstone. She was commemorated fulsomely by Catherine Hutton, for whom she 'knew all things; read all things; from reviewing new publications to sweeping the house. Her needlework was unrivalled, her landscapes, cut with scissors in writing paper incredible; and her ingenuity inexhaustible. ${ }^{37}$ Female learning is here celebrated, whilst being simultaneously aligned with virtuous domestic labour. Such artistic interests appear to have been given up on her marriage; indeed her daughter's painting talents were not encouraged, and a letter from mother to daughter tells her that a 'Wife's chief ambition ought to be to shine in the eyes of her Husband', a line that could have been written by Hannah More herself (Coltman, Stepping Stones, p. 126). Yet Elizabeth's role as Coltman's wife seems not simply to have been a domestic one. She clearly shared her husband's interests; she too was an abolitionist who considered Thomas Clarkson 'the greatest man in the kingdom' and eagerly took the opportunity, even in her seventies, to have 'an hour of delightful conversation with him' (Hutton Beale, p. 146). When, as part of his literary and philosophical discussion group, Coltman invited 'a lecturer on Electricity, Hydraulics, etc.' to give a talk, 'Mrs. Coltman, and her friend, Mrs. Reid, were the first ladies in Leicester who ventured to make their appearance in a philosophical lecture room' (p. 65). She also seems to have had to take an active role in Coltman's business, since his scholarly interests and 'insatiable' reading seem to have distracted him, and family accounts note his unworldliness. His success may therefore have owed something to his wife's support, since his son's memoirs, Time's Stepping Stones, complain,

\footnotetext{
${ }^{36}$ Susanna Watts, A Walk Through Leicester: Being a Guide to Strangers, Containing a Description of the Town and Its Environs, with Remarks Upon Its History and Antiquities (Leicester: T. Combe, 1804), see pp. 3-4, 35-41, 46-7.

${ }^{37}$ Hutton, 'Hasty Sketch of the Coltman Family'.
} 
how little sinecure that woman has, who undertakes to manage a household of which the Father is a Book-Worm and Philosopher; no less, or rather more that a man of business[...] That his business was progressive and even prosperous is true [...] but still if he had not been aided by the vigilance and care of my Mother, not only in her domestic duties, but often lending her assistance to her Husband in his own immediate department, it is doubtful if at times his love of studious ease ... might not have led him into difficulties. (Coltman, p. 92)

The 'assistance' mentioned here indicates the level to which women might have assumed authority within Rational Dissenting families, although this was not always straightforward or openly acknowledged. The Coltman family memoirs give us a glimpse of a world in which female intellect - and business acumen - was valued, although subservient to feminine domesticity and wifely obedience. Alongside such family influence, the Leicester women would also have encountered some powerful role models in the wider Dissenting community, such as Anna Laetitia Barbauld, poet, educator, and the public voice of a particular strain of female Rational Dissent. In poems such as 'Corsica', or 'Epistle To William Wilberforce, Esq. on the Rejection of the Bill for Abolishing the Slave Trade', we see her self-assumed civic identity, which would take a more radical turn in the 1790s as she spoke out - and was pilloried for doing so - on matters of conscience in works such as Civic Sermons to the People. ${ }^{38}$

A background in Rational Dissent encouraged a questioning, challenging approach in all aspects of life, with the frequent consequence that Dissenting children rejected the faith of their parents. This was the case for Elizabeth Heyrick. Her diary entries show her extreme youthful piety, as she berated herself: 'I must destroy my habits of indolence and self-indulgence - and acquire those of activity and self-denial' (Coltman, p. 149). After her husband's death, she became increasingly drawn to Quakerism, and was formally received into the Society of Friends in 1802. At the same time, she came into conflict with her family over her desire to set up a school in her home and live independently. A letter from that period concerning the school plans shows the way in which, even as she became a Quaker worshipper, Rational Dissenting emphasis on the importance of individual judgement had sunk deep into her consciousness:

${ }^{38}$ See William McCarthy, Anna Letitia Barbauld: Voice of the Enlightenment (Baltimore: John's Hopkins University Press, 2008); Anne Janowitz has done especially significant work on Barbauld's shifting voice in the 1790s in, for example, 'Amiable and Radical Sociability: Anna Barbauld's "Free Familiar Conversation," in Russell and Tuite, Romantic Sociability, pp. $62-81$. 
The rest of my family disagreeing with me in opinion is no reason why my own judgement is to be discarded as a useless thing [...] every individual must govern his actions according to the measure he has received, and not by that of another. ${ }^{39}$

Compare, for example, Theophilus Lindsey, a close associate of the Aikins and Priestley, in his sermon on the opening of the first avowedly Unitarian chapel in Essex Street, when he told the congregation that 'we can only submit to the authority of Christ in his written word, and in the sense we ourselves put upon it, and not that of another. ${ }^{40}$ This Rational Dissenting inheritance, as Clare Midgley has demonstrated, was to come together with Heyrick's new interest in Quakerism to form her outspoken abolitionist identity: 'if her family background in rational dissent had equipped Heyrick with a good education and sense of women's worth as intellectual beings, becoming a Quaker by convincement involved her following the path of her own conscience over deference to her family's wishes', and also showed her a group where females were allowed to speak out publicly as ministers (Midgley, 'Dissenting Voice', p. 98). Heyrick was not alone in rejecting the family faith: as the Great Meeting moved towards overt Unitarianism, her sister Mary Ann and their mutual friend Mary Reid moved to Harvey Lane, a Baptist congregation where the famous preacher Robert Hall ministered. Susanna Watts, whose own family background had been Anglicanism but who seems to have become an honorary member of the Coltman family, also moved towards Baptism, and her work appeared posthumously in Baptist periodicals. In Watts's scrapbook, meanwhile, a highly religious but somewhat eclectic identity emerges, since snippets of information about Moravianism, Anglicanism and Methodism, portraits of John Wesley and James Montgomery all appear, alongside hymns by Watts, and a sermon by Robert Hall preached in Leicester. While the women developed different sectarian allegiances, they all seem willing to draw from a range of approaches in order to make their points, and the description of Mary Ann by a friend, Alicia Cooper, may be telling in this regard. She did not, writes Cooper, despite her attendance at Harvey Lane, 'adopt a creed, nor be exclusive even in appearance. She believed in one universal Church [...] but she attached herself to no particular portion of it, and allowed a large latitude to all who did not see through her spectacles' (Hutton Beale, pp. 234-5). We might, then, see the women as informed by a strong local and familial culture of Rational Dissent through

${ }^{39}$ Elizabeth Heyrick to Elizabeth Coltman senr., 15 October 1802, Coltman MSS, 15D57, 64.

${ }^{40}$ Theophilus Lindsey, A Sermon Preached at the Opening of the Chapel in Essex-House, Essex-Street, in the Strand, on Sunday, April 17, 1774 (London: J. Johnson, 1774), p. 10. 
the elder Coltmans: enabled by this, they were then able to draw on different affiliations to shape their own religious identities.

They were also working within a larger tradition of Dissenting abolitionist literature. Thanks to the careful detective work of Tim Whelan, we now know more about the culture which produced the first wave of boycott literature in the 1790s. ${ }^{41} \mathrm{~A}$ key figure was the female bookseller and Baptist Martha Gurney, who published a clutch of important anti-slavery works, including sixteen radical pamphlets by the little-known William Fox, a fellow bookseller. Of these, Fox's 1791 pamphlet An Address to the People of Great Britain, on the Propriety of Refraining from the Use of West India Sugar and Rum was the most celebrated and very widely republished. It brought the abolition debate home, arguing that the way to combat slavery was for individuals to boycott the pleasure of sugar and rum. The women's boycott work owes a good deal to Fox's confrontational insistence on the individual responsibility of the consumer, and his call for complete abstention from slave-produced goods. Meanwhile, the vivid prose employed by Heyrick in her pamphlets, and the collaboratively produced Humming Bird periodical is inflected by his turn for the dramatic. The women remark in the Humming Bird that it is our duty to give a faithful picture of slavery, and if that picture be hideous, we cannot soften it', going on to argue that 'if the susceptible be disgusted by the revolting object of a flayed negro woman devoured by maggots, let them remember that the delicious sweets, which, at every repast, pass their lips, are the cause, the single cause of these agonising tortures' (p. 56). Such insistent, graphic detail might be set alongside Fox's equally vivid argument from two decades previously, that although British laws metaphorically hold such produce 'to our lips, steeped in the blood of our fellow-creatures' consumers are not compelled to 'accept the loathsome potion'.42 In doing so, they become 'partners in the crime' of slavery, the cruelties of which Fox describes in explicit physical terms, such as the ways in which slaves are lashed: 'at every stroke of the whip a piece of flesh is cut out' (p. 9). Heyrick, Watts, and their circle were drawing on this writing of the 1790s, and a culture in which a Baptist woman had been responsible for the dissemination of an extremely influential abolitionist work.

The final factor in developing the Leicester women's voice, however, seems to have been their female friendship. As single women - Elizabeth Heyrick widowed, Watts, Mary Ann Coltman, and Mary Reid unmarried, as were Catherine Hutton and Mary Linwood in the wider circle - they gained strength and community from one another's company, frequently staying with one

${ }^{41}$ Timothy Whelan, 'Martha Gurney and the Anti-Slave Trade Movement, 1788-94' in Women, Dissent, and Anti-Slavery, ed. Clapp and Jeffrey, pp. 44-65.

${ }^{42}$ William Fox, An Address to the People of Great Britain, on the Propriety of Refraining from the Use of West India Sugar and Rum (London: M. Gurney, 1791), pp. 2-3. 
another for extended periods. Their occasionally challenging attitude towards men is revealed by the sharpness of several inclusions in the scrapbook, such as Susanna Watts's 'Lines to the Rev. Robert Throsby, on his saying that a Party of Ladies who had established a little Book Society (his intimate friends) were a set of Dragons because they refused to admit him to their Meetings (1800)' (p. 545). Here, as in the 'brazen-faced' poem, Watts takes the insult and turns it into a compliment, extending the comparison between her group of female friends and the dragon, 'ever deem'd an emblem of the Wise':
Their tongues are forky - here the truth you hit;
For sure, a pointed tongue denotes a wit;
They vomit flames - your simile is here,
By ev'ry rule of rhetoric, strong and clear; -
For see you not - how from our mouth's transpire
Huge blazing volumes of poetic fire?

Like Heyrick two years later determined to maintain her opinion in the face of family opposition, Watts is issuing no apology for their decision to exclude the Reverend. Her lively poem is at once self-deprecating and defiant, a joke which is also, like the 'brazen-faced' poem, a female challenge. This is comparable to the way the Humming Bird also uses lively, sly humour, as when the title of the periodical is discussed:

"Humming Bird! No," exclaimed a Gentleman, fond of wit and repartee - "that will furnish the Anti-Abolitionists with a pun" - "all a bum" - "all humbug." (pp. 5-6)

But the women persisted with their intended title, stating if the shafts from the quivers of wit and ridicule should strike at our little plumed Messenger, so much the better', since it will afford it publicity. This is language very close to Watts's 'brazen-faced' poem, and its deflection of 'shafts of manly wit': it seems characteristic of the ways in which these Leicester women could enter into the 'warfare of political life', shielded by their intellectual and religious convictions, and given strength by a network of like-minded friends.

Thus we might see family, friendship, locality, and various strands of Dissenting religious culture coming together to shape the specific outlooks of these women, and to foster the more 'brazen' tone adopted by Heyrick, Watts, and their fellow Leicester abolitionists. While we should see them as part of a larger network of women anti-slavery activists operating in the period, we should also recognise the subtle variations in the approach of different groups which complicate our idea of a collective female voice. We need, too, not only to appreciate the significance of works by provincial women, but also 
to set them in a larger context of community and collaboration, a theme we hope to have underlined by our decision to write together. ${ }^{43}$ Academic writing, like the Leicester women's literature, is produced not by individuals working alone, but by a wider network of other researchers, stretching back to the family historians such as Samuel Coltman and Catherine Hutton Beale who set down their memories of the women's friendships, and forward to the unsung heroes of women's history, local archivists who preserve and promote the manuscripts in their care. ${ }^{44}$

\section{Bibliography}

Anon., A Brief Sketch of the Life and Labours of Mrs Elizabeth Heyrick. Leicester: Crossley and Clarke, 1862.

Aucott, Shirley. Elizabeth Heyrick 1769 to 1831: The Leicester Quaker Who Demanded the Immediate Emancipation of Slaves in the British Colonies. Leicester: Shirley Aucott, 2007.

-. Susanna Watts (1768 to 1842): Author of Leicester's First Guide, Abolitionist and Bluestocking. Leicester: Shirley Aucott, 2004.

Child, Lydia Maria. Letters of Lydia Maria Child, with a Biographical Introduction by John Greenleaf Whittier. Boston: Houghton Mifflin, 1883.

Coltman, Samuel. Time's Stepping Stones - Or Some Memorials of Four Generations of a Family - by an Octogenarian Member of the Same (1852). Record Office for Leicestershire, Leicester and Rutland, MS Misc. 1153.

Corfield, Kenneth. 'Elizabeth Heyrick: Radical Quaker', Religion in the Lives of English Women, 1760-1930, ed. Gail Malmgreen. London: Croom Helm, 1986.

Ferguson, Moira. Animal Advocacy and Englishwomen, 1780-1900: Patriots, Nation, and Empire. Ann Arbor: University of Michigan Press, 1998.

The First Report of the Female Society, for Birmingham, West Bromwich, Wednesbury, Walsall, and Their Respective Neighbourhoods, For the Relief of British Negro Slaves. Birmingham: Richard Peart, 1826.

The Fourth Report of the Female Society for Birmingham, West Bromwich, Wednesbury, Walsall, and their Respective Neighbourhoods, for the Relief of British Negro Slaves. Birmingham: 1828.

43 This chapter forms part of a larger PhD research project funded by the AHRC on Women Writers in the Midlands, 1750-1850, using the holdings of the Records Office for Leicestershire, Leicester and Rutland. One of the aims of the research project was not only to promote local archives but also to bring the women's writing into the local community with a series of public events including creative writing workshops, a poetry pamphlet, and involvement in a film, 'Rothley, Slavery and Me', produced by the Community Interest Corporation, Candy Arts.

${ }^{44}$ We would specifically like to thank Jess Jenkins of the Records Office for her generous assistance and sharing her research on the Leicester women. 
Fox, William. An Address to the People of Great Britain, on the Propriety of Refraining from the Use of West India Sugar and Rum. London: M. Gurney, 1791.

Gardiner, William. Music and Friends: Or, Pleasant Recollections of a Dilettante, 2 vols. London and Leicester: Longmans, 1838.

Gleadle, Kathryn. 'British Women and Radical Politics in the Late Nonconformist Enlightenment, c.1780-1830', Women, Privilege and Power, ed. Amanda Vickery. Stanford: Stanford University Press, 2001.

-. The Early Feminists: Radical Unitarians and the Emergence of the Women's Rights Movement, 1831-51. New York: St Martin's Press, 1995, 2 $2^{\text {nd }}$ edn. 1998.

Heyrick, Elizabeth to Elizabeth Coltman senr., 15 October 1802, Coltman MSS, 15D57, 64.

-. Immediate, not Gradual Abolition: Or, An Inquiry Into the Shortest, Safest, and Most Effectual Means of Getting Rid of West Indian Slavery. London: Hatchard, 1824.

- Letters on the Necessity of a Prompt Extinction of British Colonial Slavery: Chiefly Addressed to the More Influential Classes, to which are Added, Thoughts on Compensation. London and Leicester, 1826.

Hutton Beale, Catherine. Catherine Hutton and her Friends. Birmingham: Cornish Brothers, 1895.

—. 'Hasty Sketch of the Coltman Family' (1802). Record Office for Leicestershire, Leicester and Rutland, MS 15D57/387.

Janowitz, Anne. 'Amiable and Radical Sociability: Anna Barbauld's "Free Familiar Conversation"', Romantic Sociability: Social Networks and Literary Culture in Britain, 1770-1840, ed. Gillian Russell and Clara Tuite. Cambridge: Cambridge University Press, 2002.

Leicester Auxiliary Anti-slavery Society. An Address on the State of Slavery in the West India Islands. London: Hamilton and Leicester: T. Combe, 1824.

Letters of Lydia Maria Child. Boston: Houghton Mifflin, 1883.

Lindsey, Theophilus. A Sermon Preached at the Opening of the Chapel in Essex-House, Essex-Street, in the Strand, on Sunday, April 17, 1774. London: J. Johnson, 1774.

McCarthy, William. Anna Letitia Barbauld: Voice of the Enlightenment. Baltimore: Johns Hopkins University Press, 2008.

Midgley, Clare. 'The Dissenting Voice of Elizabeth Heyrick: An exploration of the Links between Gender, Religious Dissent and Anti-Slavery Radicalism', Women, Dissent and Anti-Slavery in Britain and America, 1790-1865, ed. Elizabeth Clapp and Julie Roy Jeffrey. Oxford: Oxford University Press, 2011.

More, Hannah. Strictures on the Modern System of Female Education, With a View of the Principles and Conduct Prevalent Among Women of Rank and Fortune. London: T. Cadell Junior and W. Davies, 1799.

Patterson, A. Temple. Radical Leicester. A History of Leicester 1780-1850. Leicester: University College Leicester, 1954.

'Preface'. The Humming Bird; or, Morsels of Information, on the Subject of Slavery. London: A. Cockshaw, 1825. 
Reeves, Marjorie. Female Education and Non-Conformist Culture, 1700-1900. Leicester: Leicester University Press, 2000.

Report of the Sheffield Female Anti-Slavery Society. Sheffield: 1825.

Report of the Sheffield Female Anti-Slavery Society. Sheffield: J. Blackwell, 1827.

Russell, Gillian and Clara Tuite, eds. Romantic Sociability: Social Networks and Literary Culture in Britain, 1770-1840. Cambridge: Cambridge University Press, 2002.

The Second Report of the Female Society for the Relief of British Negro Slaves. Birmingham: 1826.

Twells, Alison. "We Ought to Obey God Rather Than Man”: Women, Anti-Slavery and Nonconformist Religious Culture', Women, Dissent and Anti-Slavery in Britain and America, 1790-1865, ed. Elizabeth Clapp and Julie Roy Jeffrey. Oxford: Oxford University Press, 2011.

Vickery, Amanda, ed. Women, Privilege, and Power: British Politics, 1750 to the Present. Stanford: Stanford University Press, 2001.

Watts, Ruth. Gender, Power and the Unitarians in England, 1760-1860. London and New York: Routledge, 1998.

Watts, Susanna. The Insects in Council, Addressed to Entomologists, with other Poems. London and Leicester: Hurst and A. Cockshaw, 1828.

- Scrapbook, The Record Office of Leicestershire, Leicester and Rutland, Rare Books, L. A. Watts.

-. A Walk Through Leicester: Being a Guide to Strangers, Containing a Description of the Town and Its Environs, with Remarks Upon Its History and Antiquities. Leicester: T. Combe, 1804.

Whelan, Timothy. 'Martha Gurney and the Anti-Slave Trade Movement, 1788-94', Women, Dissent and Anti-Slavery in Britain and America, 1790-1865, ed. Elizabeth Clapp and Julie Roy Jeffrey. Oxford: Oxford University Press, 2011.

- Nonconformist Women Writers, 1720-1840. London: Pickering \& Chatto, 2011.

-. Other British Voices: Women, Poetry, and Religion, 1766-1840. New York: Palgrave Macmillan, 2015.

Wilberforce, Robert Isaac and Samuel Wilberforce. The Life of William Wilberforce by His Sons, 5 vols. London: John Murray, 1839.

Wykes, David L. 'The reluctant businessman: John Coltman of St Nicholas Street, Leicester, 1727-1808'. Transactions of the Leicestershire Archaeological and Historical Society (1995). 


\title{
Ageing, Authorship, and Female Networks in the Life Writing of Mary Berry (1763-1852) and Joanna Baillie (1762-1851)
}

\author{
Amy Culley
}

My dear Friend, I have just read your proof-sheet, in which you have made such honourable mention of an author so much forgotten by the public, and think you are a very bold and pertinacious woman to venture at this time of the day to put her in the eminent station you have assigned to her. However, I am well pleased to receive such distinction from your partiality and constancy, the tried constancy of many years, and thank you for it with all my heart. ${ }^{1}$ (Joanna Baillie letter to Mary Berry, ?March 1831)

This expression of affection and gratitude is addressed to the author Mary Berry from her 'dear Friend', poet and playwright Joanna Baillie, in acknowledgement of Berry's Social Life in England and France, from the French Revolution in 1789, to that of July 1830 (1831). On reading Berry's proofs, Baillie would have found herself positioned alongside Byron in a literary review of the era as poets who 'amazed a busy and calculating world with bursts of original pathos and poetry, worthy of the more poetic ages of society. ${ }^{2}$ This letter offers a glimpse of a literary friendship characterised by manuscript exchange, mutual encouragement, and a collaborative approach to constructing a public reputation. For in her role as biographer and historian, Berry worked to secure Baillie's place within the canon while establishing herself as a commentator on the literature of her day. But Baillie's reference to

Thanks are owed to the BA/Leverhulme Small Grants Scheme for support in funding this research.

${ }^{1}$ Further Letters of Joanna Baillie, ed. Thomas McLean (Madison: Fairleigh Dickinson University Press, 2010), p. 139.

2 Mary Berry, Social Life in England and France, from the French Revolution in 1789, to that of July 1830 (London: Longman, Rees, Orme, Brown, and Green, 1831), p. 46. 
'this time of the day' also reminds us of these friends' shared status as older women writers (both nearing seventy by 1831) who conversed, published, and together attempted to secure their literary afterlives into the nineteenth century.

Devoney Looser's research has shown that attending to the full careers of eighteenth-century and Romantic women writers who 'were active well into the nineteenth century' can 'refigure' 'our visions of literary history' by complicating ideas of 'periodization, authorial and generic trends, or the literary marketplace. ${ }^{3}$ Looser's detailed case studies of long-lived female authors provide 'new insights about authorship across the life course' in highlighting the circumstances and challenges literary women faced in old age and their cultural and critical reception during their own lifetimes and beyond. ${ }^{4}$ The role of older women's literary friendships in this fascinating narrative of ageing, authorship, and gender is yet to be fully explored, as Looser notes 'there is much yet to learn about the social, intellectual, and professional networks of aged writers of both sexes' (Looser, Women Writers, p. 20). Reading the correspondence and (auto)biographical writing of Baillie and Berry written from the 1790s to the mid-nineteenth century provides a rare opportunity to investigate this theme. These works depict creative and collaborative exchanges, relationships with writers (both from their own generation and the next), professional interactions with publishers and booksellers, anxieties of reception, the pleasures and pains of ageing, and their commitment to continued publication into late life.

In addition to contributing to studies of Romanticism and old age, conversely, reading literary networks and social authorship through the lens of ageing and the life course brings into sharper focus intra- and intergenerational connections and locates Berry and Baillie within and beyond Romantic literary culture. As Helen Yallop argues, we know little about 'intergenerational sociability' in the period because studies 'have been more concerned with the interactions between those of different sex and social standing. ${ }^{5}$ To date, Berry and Baillie's familial networks have been the focus of some rewarding critical attention as part of the growing recognition of family authorship 'as a distinctive and influential cultural formation of the Romantic period'. ${ }^{6}$

${ }^{3}$ Devoney Looser, Women Writers and Old Age in Great Britain, 1750-1850 (Baltimore: Johns Hopkins University Press, 2008), pp. 6-7.

${ }^{4}$ Devoney Looser, 'Age and Aging', in The Cambridge Companion to Women's Writing in the Romantic Period, ed. Devoney Looser (Cambridge: Cambridge University Press, 2015), pp. 169-82 (p. 178).

5 Helen Yallop, Age and Identity in Eighteenth-Century England (London: Routledge, 2013), p. 114.

${ }^{6}$ Michelle Levy, Family Authorship and Romantic Print Culture (Basingstoke: Palgrave Macmillan, 2008), p. 2. 
Julie Carlson highlights the influence on Baillie's drama of her close relationship with her brother, the physician Matthew Baillie, ${ }^{7}$ while Judith Bailey Slagle foregrounds the relationship between sisters in her discussion of Agnes Berry (1764-1852) and Agnes Baillie (1760-1861) who demonstrate 'how creative and determined women were often influenced by their more "silent" sisters'. ${ }^{8}$ Berry is also a central figure in Susanne Schmid's study of British literary salons that perpetuated bluestocking traditions into the early nineteenth century, a form of female community which has been vital to our understanding of women's intellectual affiliations. ${ }^{9}$ Building on this research, my focus is the longstanding friendship and model of 'companionate authorship' that fostered the careers of Berry and Baillie within their overlapping personal and professional networks. ${ }^{10}$ Situating these writers within wider circles of friendship also recalls authorial interactions across literary periods (exemplified by Berry's status as both editor of Horace Walpole and friend to William Thackeray) and their connections with other long-lived female writers (including Baillie's friendships with Anna Barbauld and Maria Edgeworth). It also shows how such friendships contributed to their authorial self-fashioning in late life and their efforts to shape their posthumous reputations.

In this context, extending the analysis of life writing materials to include the biographical prefaces, obituaries, and collective biographies that followed the deaths of Baillie and Berry helps us to better understand and perhaps even 'refigure' the enduring critical legacies of these authors. Louise Duckling has identified Baillie's status as a "proper lady" and a 'paragon of female excellence', most at home in the kitchen or with her needle, as central to her image and popularity in the nineteenth century. This public image enabled Baillie to 'negotiate gender roles on the public stage', but in Duckling's view, also resulted in an overshadowing of the 'intellectual vigour' and 'cultural value' of her drama and theatre theory; a distortion of literary history which recent

7 Julie A. Carlson, 'Social, Familial, and Literary Networks', in Cambridge Companion to Women's Writing, pp. 145-57 (p. 152); See also, Frederick Burwick, 'Joanna Baillie, Matthew Baillie, and the Pathology of the Passions', in Joanna Baillie, Romantic Dramatist: Critical Essays, ed. Thomas C. Crochunis (London: Routledge, 2004), pp. 48-68.

${ }^{8}$ Judith Bailey Slagle, 'Sisters - Ambition and Compliance: The Case of Mary and Agnes Berry and Joanna and Agnes Baillie', in Woman to Woman: Female Negotiations During the Long Eighteenth Century, ed. Carolyn D. Williams, Angela Escott, and Louise Duckling (Newark: University of Delaware Press, 2010), pp. 79-100 (p. 81).

9 Susanne Schmid, British Literary Salons of the Late Eighteenth and Early Nineteenth Centuries (Basingstoke: Palgrave Macmillan, 2013).

${ }^{10}$ Marjorie Stone and Judith Thompson, 'Contexts and Heterotexts: A Theoretical and Historical Introduction', in Literary Couplings: Writing Couples, Collaborators, and the Construction of Authorship, ed. Marjorie Stone and Judith Thompson (Madison: University of Wisconsin Press, 2006), pp. 3-37 (p. 29). 
scholarship on Baillie is working to correct. ${ }^{11}$ My study contributes to this more complex picture of Baillie through exploring her ongoing interest in professional authorship, literary celebrity, and connections to the next generation articulated in her life writing in old age (including her unpublished memoirs 'Recollections Written at the Request of Miss Berry' and 'Memoirs Written to please my Nephew William Baillie'). ${ }^{12}$ By comparison, Schmid suggests that Berry experienced a 'posthumous oblivion' which may have been caused by a combination of her 'lack of openly acknowledged authorship' and her status as an 'author of the social sphere, between private and public' (p. 69). ${ }^{13}$ Berry's works were written for a larger audience and widely read and acknowledged by friends and acquaintances, but on publication the identity of the author was generally obscured on the title page. ${ }^{14}$ In addition, her preference for working in the genres of social history, biography, and a posthumously published journal (rather than fiction, drama, or poetry), and her roles as editor, critic, and salonnière, have made the value of her contribution to the literary culture of the Romantic period more difficult to assess both in the aftermath of her death and in subsequent literary scholarship. Examining Berry's enduring relationship with Baillie, recorded in their life writing, provides an intimate insight into her role in making and shaping another woman's literary career and posthumous reputation. Furthermore, a consideration of her own writing into the nineteenth century suggests how she sought to exploit the persona of the older woman writer as a historian and critic of the age.

${ }^{11}$ Louise Duckling, 'Coming Out of the Closet and Competing with John Anybody: The Bold World of Joanna Baillie', in British Women and the Intellectual World in the Long Eighteenth Century, ed. Teresa Barnard (London: Routledge, 2016), pp. 143-55 (pp. 153-5). The biographical narrative of Baillie as a 'woman in retirement' was perpetuated into the twentieth century by Margaret Carhart's The Life and Work of Joanna Baillie (North Haven: Archon Books, 1970), originally published in 1923. Scholars including Judith Bailey Slagle, Louise Duckling, Catherine Burroughs, and others, have provided a valuable corrective to this account. Catherine B. Burroughs, Closet Stages: Joanna Baillie and the Theater Theory of British Romantic Women Writers (Philadelphia: University of Pennsylvania Press, 1997).

${ }^{12}$ For instance, focusing on Baillie's late life writing complicates Looser's portrait of Baillie as an ideal of the woman writer in old age in her commitment to retirement and philanthropy. Women Writers, pp. 24-5.

${ }^{13}$ For a more detailed picture of Berry's approach to anonymous and semi-anonymous publication, see Schmid, pp. 65-6.

${ }_{14}$ As an example, Berry 'edited the posthumous collection of The Works of Horatio Walpole, Earl of Orford, published in five volumes (1798), although her father was named as editor'. $(O D N B)$. Berry seems to have been committed to semi-anonymous publication to a wider audience rather than circulation in manuscript to a select community of readers. 


\section{A Companionate Correspondence}

The correspondence of Berry and Baillie demonstrates the importance of imagining eighteenth-century women writers 'as professionalized subjects, as agents in the public sphere of letters', as Betty Schellenberg has encouraged us to do, while suggesting how friendship and collaboration might further women's literary ambitions. ${ }^{15}$ In her painstaking work on Baillie's correspondence, Slagle argues that the letters that survive between Berry and Baillie provide important evidence of the ways in which 'these literary women worked together to ensure each other's success'. ${ }^{16}$ Berry's first encounter with Baillie was as a reader and advocate of her plays; setting the terms for their relationship thereafter. Berry notes in a letter to a friend in 1799 that the previous winter she had been sent a copy of Baillie's Plays on the Passions by the anonymous author, had spoken to 'everybody' of their merits 'in high terms', but had generally been ignored. Now, she laments, 'everybody talks in the raptures (I always thought they deserved)'. Berry demands recognition as Baillie's early and most discerning reader, in contrast to the 'obdurate public', and reveals her commitment to promoting the text within her circle. Despite its anonymity, the text is claimed by Berry for a female literary tradition, 'because no man could or would draw such noble, such dignified representations of the female mind'. Berry shows a more flexible attitude to gender and genre here than critics who commonly 'ranked the unknown author amongst the best of men' due to Baillie's 'dramatic experiment' and participation 'in the medical and philosophical debates of her day' (Duckling, pp. 143-4). Berry also suggests that 'all this talking and thinking about plays' inspires her own creative ambitions and left her 'itching' to return to her own 'long-forgotten' play which had 'probably better be left untouched to my executors. ${ }^{17}$ Berry did, nonetheless, return to playwriting, and by 1801 Baillie had contributed a prologue and epilogue to Berry's play Fashionable Friends for a private theatrical at Strawberry Hill (with a cast that included sculptor Anne Damer, both Berry sisters, and Berry's father). ${ }^{18}$

These acts of reading, commentary, creative inspiration, and advocacy are characteristic of the productive literary partnership traceable in Baillie and

${ }^{15}$ Betty A. Schellenberg, The Professionalization of Women Writers in Eighteenth-Century Britain (Cambridge: Cambridge University Press, 2005), p. 181.

${ }^{16}$ Judith Bailey Slagle, Joanna Baillie: A Literary Life (Madison: Fairleigh Dickinson University Press, 2002), p. 119.

17 Extracts of the Journals and Correspondence of Miss Berry from the Year 1783 to 1852, ed. Lady Theresa Lewis, 3 vols. (London: Longmans, Green and Co, 1865), II: pp. 88-90.

${ }_{18}$ The play was staged (unsuccessfully) at Drury Lane in 1802 without naming Berry as the author. For further discussion of Fashionable Friends, and the hostile critical reception it inspired, see Susanne Schmid, 'Mary Berry's Fashionable Friends (1801) on Stage', The Wordsworth Circle (2012), pp. 172-7. 
Berry's correspondence in the years that followed. Bette London argues that "collaborations exist in a range of "authorial" activities not necessarily named authorship: acts of assistance and inspiration; acts of mentoring or mutual influence; acts of revision or editorial input. ${ }^{19}$ This capacious definition enables potentially invisible forms of collaboration to come into view, as women wrote and published in close consultation and exerted authorial agency as editors and readers of one another. Berry's Journal testifies to the women's commitment to exchanging their work in manuscript for comment. In her account of a visit to Baillie in May 1811, Berry records that following a 'delicious fine evening' on Hampstead Heath, the two women 'read over together' her new play 'The Two Martins' 'and criticised them, and likewise some of my other scraps, which I think Joanna liked less than I expected'. ${ }^{20}$ The following day the disappointment was mutual, as Berry notes, 'sat by the fire the whole day. Joanna Baillie gave us her drama upon Hope to read' but the work 'did not equal my expectation'; 'a sufficiently dramatic story, but not dramatically managed' (Berry, Extracts, II: p. 477). These evocative scenes operate in the 'ambiguous zones in which conversation crosses over into shared inspiration, intertextual dialogue, or collaboration' (Stone and Thompson, p. 23). The most explicit instance of collaboration occurs later in life when Baillie sends Berry a story which she suggests could form the basis of a play. Friendship and care as much as shared literary endeavour are the motivation here since this occurs during a melancholy period for Berry and Baillie advocates the therapeutic effects of literary 'occupation' that will 'do you good'.

If you think it can be made such a thing as you would like to write upon let me know what alterations you would wish to have made upon it [...] and I shall alter it \& re-alter it twenty times over till I get it to suit you. But if you should not fancy it at all, tell me so frankly and then I will try to rake something else out of my noddle that will do better [...]. As to devisions $[s i c]$ of scenes and sketching of character, we shall say nothing of that at present: it will be time enough to talk of it when the story or outline of the plot is fix'd upon. ${ }^{21}$

The play does not seem to have materialised ${ }^{22}$ but the impulse suggests the ways in which literary practice was not only focused on publication but also

${ }^{19}$ Bette London, Writing Double: Women's Literary Partnerships (Ithaca: Cornell University Press, 1999), p. 19.

${ }^{20}$ Berry's play does not survive and she seems to have written no further dramas.

${ }^{21}$ The Collected Letters of Joanna Baillie, ed. Judith Bailey Slagle, 2 vols. (Madison: Fairleigh Dickinson University Press, 1999), I: p. 175.

${ }^{22}$ Slagle suggests that this story is the one contained in the Royal College of Surgeons' Library: HB. ix-69a-c. Collected Letters of Joanna Baillie, I: p. 175. 
embedded within friendship and imagined as an extension of conversation, correspondence, and care.

The letters also establish Berry as part of a network of women who acted as critics and editors of Baillie's manuscripts. Writing to Berry in 1806, Baillie comments, 'Mrs Damer tells me in her note [...] that there are some corrections you have to make on the last acts of my Family Legend, and I should be glad to know what they are as soon as may be'. The urgency is due to Baillie's desire to incorporate Berry's revisions alongside the 'friendly corrections' provided by Anne Damer, suggesting that her work is shaped at least in part by this social circle of editors (Baillie, Letters, I: pp. 158-9). Berry's Journal records her ongoing relationship with Baillie's play and establishes her contributions to its reception and dissemination. At a breakfast in 1809 she recalls 'somebody was to read Joanna Baillie's tragedy, "The Family Legend;" this somebody was obliged to be me, as nobody else knew her hand, or had ever seen the play'. Also preserved for posterity is the detail that the reading 'had a vast effect upon Walter Scott, and one that was very pleasing, from the evident feeling of one poet for another' (Berry, Extracts, II: p. 381). ${ }^{23}$ Berry, like her salon, acts as a conduit for an exchange between poets who were themselves corresponding from 1808. Thereafter, Scott wrote a prologue for the play and arranged for it to be produced in Edinburgh. In subsequent years, Berry's experience of the play migrated to a more overtly public setting when she attended a performance at Drury Lane in 1815, noting: 'It could not have been worse acted; however the fine lines, spoilt as they were, were appreciated and applauded by the pit' (Berry, Extracts, III: p. 50). Berry thereby records the appreciation of a (discerning) audience of the middling and professional classes for a play she had known by this stage for nearly ten years.

As literary works were performed or published, both women remained attentive to the other's achievements. Letters show that copies of new publications, often inscribed with 'the very partial expressions of a friend' (Berry, Extracts, III: p. 370), are precious and reciprocal gifts. Baillie apologises when the copy of Metrical Legends (1821) set aside for Berry is mistakenly sent to someone else and suggests of the second edition that 'no body shall take it out of my hands till I put it into your[s]' (Baillie, Letters, I: p. 171). Likewise, on receipt of a copy of Berry's Some Account of the Life of Rachael Wriothesley Lady Russell (1819), Baillie comments both on the text's 'intrinsic value' and 'the value I particularly set upon it as your gift, and a token of your regard' (Berry, Extracts, III: p. 176). In addition to expressing friendship, such exchanges also enable both women to reveal anxieties and receive reassurance regarding public reception, as Berry accompanies a copy of $A$ Comparative View of the

${ }^{23}$ See Schmid, p. 58 for a discussion of this anecdote in the context of the culture of the literary salon. 
Social Life of England and France: From the Restoration of Charles the Second, to the French Revolution (1828) with the admission that 'I have no hopes of any popularity for my book. It will fall between wind and water. The trifling will think it dull, and graver readers will not think of it at all', prompting Baillie's more confident assertion that it can 'scarcely fail of success' (Berry, Extracts, III: pp. 369-70). There is also a deep engagement with the works themselves, particularly on questions regarding women's writing and a female readership. Baillie has high praise for Berry's biography of Rachel Russell as 'a pleasing and edifying example to the young women of the day' (Berry, Extracts, III: p. 176). But she is less certain regarding the propriety of $A$ Comparative View of the Social Life of England and France. She commends the style, spirit, and observation of Berry's text, but confident that friendship can withstand 'sincere opinion' she expresses her doubts about the 'delicacy' of a woman writer narrating the lives of scandalous women. Berry's response invokes genre in her defence as she argues that history offers greater licence than fiction:

I have only to say that, if women treat of human nature and human life in history and not in fiction (which perhaps they had better not do), human nature and human life are often indelicate; and if such passages in them are treated always with the gravity and the reprobation they deserve, it is all a sensible woman can do, and (not writing for children) all she can think necessary. (Berry, Extracts, III: pp. 371-2)

In her turn, Berry's concerns lay not with questions of feminine propriety, but rather Baillie's public interventions in religious debates in $A$ View of the General Tenour of the New Testament Regarding the Nature and Dignity of Jesus Christ (1831). Berry falls short of direct criticism of Baillie, but is nonetheless equivocal regarding the value of public professions of faith and cautions that 'liberal opinions' are 'so apt to be mistaken. ${ }^{24}$

This interest in the opportunities and challenges of female authorship permeates the letters and Baillie and Berry are both keen to use their connections to promote the careers of others. Baillie solicits a subscription from Berry in 1806 for a publication by Miss Warner of Bath, 'a shy, retired' single woman writing to support herself, her mother, and her widowed sister. During the same period, Baillie responds to Berry's request to speak to her publisher Thomas Longman regarding the work of Miss Seaton (Baillie, Letters, I: pp. 160-1). ${ }^{25}$ In 1823 Baillie combined 'literary philanthropy' with

${ }^{24}$ Mary Berry letter to Joanna Baillie, Wellcome Library, MS 5613 77/1, 21 September 1832.

${ }^{25}$ Slagle suggests this is probably Rebecca Warner, author of Original Letters (1817) and Epistolary Curiosities (1818). 
canon formation in A Collection of Poems, Chiefly Manuscript, and from Living Authors, a work edited for the financial benefit of her widowed former school friend Mrs. Stirling and including contributions by Felicia Hemans, William Wordsworth, Anna Barbauld, and Robert Southey amongst many others. ${ }^{26}$ The women also exchange news on recent publications, such as Childe Harold that is recommended by Berry and Scott by letter on the same day. Closer to home, Baillie pictures herself and her sister 'deeply engaged' with Lucy Aikin's newly published Memoirs of the Court of Charles I (1833), before noting 'very entertaining \& interesting. I suppose you have seen it' (Baillie, Letters, I: p. 174). Here intergenerational friendship is expressed through reading; Baillie was friend to Aikin's aunt, Anna Barbauld, and Aikin would later publish her 'Recollections of Joanna Baillie' in 1864.

However, the focus of epistolary dialogue was not solely literary and letters also provide space for Baillie and Berry to explore the personal narratives of their lives. Their shared identity as single women shapes these conversations and their understanding of the life course. In a letter of 1805, Baillie advises Berry to think carefully before rejecting a marriage proposal received in her forties because 'you wish for employment, and you wish to be useful in the world: as the Wife of a man of fortune you will have this much more in your power than you are ever likely to have by remaining single'. But despite this apparent support for marriage on the basis of public utility, Baillie nonetheless concludes that 'every single woman, who is to remain so, has great pride in seeing such a woman as you of her Sister hood, and cannot possibly see you quitting the ranks but with considerable regret' (Baillie, Letters, I: p. 157). The familial and military metaphors position Baillie and Berry within a broader network of single women and implicitly present friendship as an alternative to conjugal bonds. Around nine years later, Baillie explains her decision in her fifties to refer to herself and her sister as 'Mrs' because 'I have always thought that when single women are advanced in years and Mistress of a house with neither Father nor Mother over their heads, they might assume this with propriety' (Baillie, Letters, I: p. 167). It is notable that as well as their shared status as single women, age is an important element of their intimacy and, particularly as they grow older, 'at our time of life' becomes a recurrent refrain in the letters. ${ }^{27}$

This awareness of their position in the life course is evident in detailed accounts of the ageing body (including physical frailty, medical symptoms, treatment, and convalescence) as well as remarks on social perceptions of older women. Berry generally adopts a melancholy tone in her reflections on the

${ }^{26}$ Paula R. Feldman, British Women Poets of the Romantic Era: An Anthology (Baltimore: Johns Hopkins University Press, 2000), p. 25.

${ }^{27}$ For an example, see Mary Berry letter to Joanna Baillie, MS 5613 77/1, 21 September 1832. 
experiences of ageing, whereas Baillie's letters often work more optimistically to provide encouragement and reassurance. Addressing public perceptions of Berry when both women were in their seventies, Baillie speaks with the authority of a lifelong friend, noting 'I do not wonder that people should forget your age; in company you seem to have spirit and vigour for anything [...] your eyes nearly as bright as they were some twenty years ago' (Berry, Extracts, III: p. 442). Elsewhere, her comments adopt a more self-reflective mode providing a dual portrait in her reassuring address to Berry:

But you go down the hill gently, and are not afraid of the last step; and may God support both you and me, and give us comfort and consolation when it is most wanted! As for myself, I do not wish to be one year younger than I am, and have no desire, were it possible, to begin life again, even under the most favourable circumstances. (Berry, Extracts, III: p. 453)

The spatial metaphor of the hill echoes Berry's own writing in which she variously imagines herself in her later years on a slope, plane, or a terrace and travelling downhill. But downhill is not equated with obsolescence for in an elaborate metaphor of 1840 Berry asserts her modernity, commenting that 'after having been long posting downhill, I am now going at Railway pace - I wish I was sure of getting to the Terminal without any accident. ${ }^{28}$ These shared reflections on ageing and identity in terms of gender, social perceptions, and physical change, and the attempts to articulate feelings prompted at different stages of the life course, are a welcome reminder that identity and friendship have 'diachronic aspects' (Yallop, p. 148) which evolve in response to the passing of time. ${ }^{29}$

Their correspondence shows that, in addition to their friendship, their selfconception as professional authors is also inflected by age. Mutual support for each other's literary careers is influenced by their position as older women in their shared anxieties regarding the print marketplace, critical reception, and literary afterlives. Looser's study has highlighted how, in the Romantic period, 'a number of aged women writers saw their reputations and fame diminishing before their eyes, and a few fought to reverse the process' (Looser,

${ }^{28}$ Mary Berry, 'The Berry Papers: Correspondence, Papers and Journals of Mary Berry (1763-1852), Add MS37758, British Library, 6 November 1840. These reflections are excluded from Lewis's printed edition, but are extant in the manuscript of Berry's Journal held at the British Library.

${ }^{29}$ Yallop is drawing on Margaret Morganroth Gullette's insight that identity theorists and, Yallop argues, eighteenth-century historians, have too often neglected the category of age in studies of personal identity, see Margaret Morganroth Gullette, Aged by Culture (Chicago: University of Chicago Press, 2004), pp. 121-2. 
Women Writers, p. 7). In this case, collaboration is key to resisting a narrative of decline, for just as Berry had first promoted Baillie as a playwright in her salon in the 1790s, thirty years on she continued to contribute to Baillie's public reputation. To return to Berry's Social Life in England and France, from the French Revolution in 1789, to that of July 1830, there is a palpable desire to engage with debates regarding Baillie's critical reputation and defend her friend's contribution to literary history. Berry draws on her authority as an older woman to provide a retrospective survey of the age and position Baillie within it. In her portrait, Berry evokes a paradigm of Romantic genius in claiming Baillie was 'born a Poet in the truest and most exalted sense of the word'. Nonetheless, she suggests that Baillie's innate powers are circumscribed by sex given that 'the retired nature and virtuous habits of women confine their observation of human life and passion within a much smaller circle than that always open to man'. As a consequence, Baillie excels in 'exquisitely portrayed characters of excellence and of virtuous feeling' consistent with her own exemplary character. If that might expose her to accusations of 'sameness' due to her resistance to dealing with vice and violent passions then it is noted that Byron is equally repetitious in his preference for Eastern subjects and love of profligacy and skepticism (Berry, Social Life, p. 47).

\section{Writing Lives Together ${ }^{30}$}

Berry's impulse in Social Life in England and France to secure Baillie's place in literary history seems to have been part of a shared project of the early 1830 s to respond to past criticism, challenge critical obsolescence, and construct a posthumous reputation. The retrospective vantage point offered by late life, which Berry uses to good effect in her social history, was, in the same year, put to work by Baillie in an autobiographical mode in response to encouragement by Berry. At the age of 69, Baillie composed a manuscript fragment 'Recollections Written at the Request of Miss Berry' retained in the archives of the Royal College of Surgeons. Four years later, in 1835, Baillie followed this with a companion piece 'Memoirs Written to please my Nephew William Baillie', written in dialogue with the earlier recollections for Berry and preserved in the Wellcome Library. ${ }^{31}$ As the titles suggest, Baillie presents a highly

\footnotetext{
${ }^{30}$ My subtitle is borrowed from the conference, 'Writing Lives Together: Romantic and Victorian Biography', University of Leicester, September 2015 where this research was first presented. I am grateful to the organisers and delegates for the very useful feedback on the original paper.

${ }_{31}$ Baillie's papers are in the archives of the Royal College of Surgeons and the Wellcome Library due to her family connections to Matthew Baillie, physician to George III, and William and John Hunter, both celebrated eighteenth-century surgeons. For a fuller discussion of Baillie's biography in relation to these manuscripts, see Judith Bailey Slagle,
} 
networked model of authorship in her examination of the ways in which family, friendship, and the literary marketplace shaped her career, while at the same time engaging with ideas of Romantic genius and professionalism. Reading these two manuscripts in conjunction therefore offers a more nuanced picture of Baillie's authorial self-fashioning in late life than her nineteenth-century incarnation as a model of retirement and feminine virtue might suggest.

'Recollections Written at the Request of Miss Berry' implies that friendship acts as a spur to self-writing as the recollections are, at least in part, an extension of the women's conversation and correspondence. For instance, Baillie interrupts her history of learning to write by noting in self-deprecating style, 'I think I have told you that many a time in writing letters, I have used not such words as I wished and as best expressed my meaning but such as I know how to spell'.32 Baillie introduces key autobiographical themes, particularly the influence of her family on her literary career and her Romantic privileging of imagination over education, while carefully balancing feminine propriety and professional authorship and offering a lengthy disquisition on her early fascination with geometry. Her sister Agnes is credited with teaching her to read (which culminates in her love of Ossian, Milton, and the sisters' shared passion for ghost stories) while with her school friends she finds her first audience as 'a contriver of tales'. Authorship is in part feminised and domesticated, but in Baillie's recollection of composing a play 'while my fingers were employed in sprigging muslin for an apron' she resists the traditional opposition of pen and needle detected by Valerie Sanders in the life writing of women as diverse as Laetitia Pilkington, Margaret Oliphant, and Harriet Martineau. ${ }^{33}$ Even in this domestic context there are hints which undercut a narrative of feminine modesty when Baillie competes with and outshines her brother in his school exercise of writing couplets on the seasons. Her mother expresses anxiety regarding her daughter's vanity in writing verses and 'very sensibly knocked that on the head', but this discouragement is countered by her brother's 'hearty \& manly praise' for her first endeavours as a playwright.

The manuscript ends abruptly leaving Baillie in childhood, but these threads of family, friendship, and literary professionalism are amplified in Baillie's second attempt, 'Memoirs Written to please my Nephew William Baillie', composed by Baillie at the age of $73 .{ }^{34}$ Baillie seems to have grown in confidence in

'Evolution of a Writer: Joanna Baillie's Life in Letters', in Joanna Baillie, Romantic Dramatist: Critical Essays, pp. 8-26.

32 Joanna Baillie, 'Recollections Written at the Request of Miss Berry' (1831), Royal College of Surgeons, Hunter-Baillie, MS0014/3. All subsequent quotations are from this manuscript.

${ }_{33}$ Valerie Sanders, The Private Lives of Victorian Women: Autobiography in NineteenthCentury England (Hemel Hempstead: Harvester Wheatsheaf, 1989), p. 44.

${ }^{34}$ This work formed part of a wider project of family authorship preserved in the archive. 
articulating a narrative of professional authorial vocation and retrospectively re-evaluates the earlier 'Recollections' as a more modest gesture. The 'little memoir in the possession of Miss Berry' is referred to as a source of 'drole whimsical anecdotes', whereas this text seems more concerned with events that 'had any influence on my mind, connected with the writings of my after life'. ${ }^{35}$ What emerges here is a more detailed engagement with Romantic myths of authorship and a commentary on the potential barriers to professional success and critical acclaim for women writers. Linda Peterson argues that by the mid-nineteenth century "many women writers embraced the "parallel streams" model' that 'separated the woman from the author, the private, domestic self from the public persona and literary creator' in order to 'preserve the category of artistic genius for women's authorship, even while demonstrating that literary women could fulfill (and would not abandon) the duties of domestic life'. ${ }^{36}$ As a single woman Baillie was not required to reconcile her credentials as a wife and mother with literary genius, and while family relationships play an integral role in artistic production they comfortably coexist and intertwine with accounts of genius and professional interactions. Baillie is heavily invested in Romantic myths of childhood, focusing on 'chiefly out of door recollections' and suggesting that her imagination was fostered by nature, encounters with rural life, visits to see paintings and gardens, and excursions to the forest, all of which 'did my fanciful untaught mind much good'. Baillie's 'Introductory Discourse' to Plays on the Passions (1798), in which she stresses the importance of representing 'the plain order of things in this every-day world', is now recognised as an important influence on Wordsworth and Coleridge's preface to Lyrical Ballads (1798). ${ }^{37}$ Likewise, the model of Romantic childhood which emerges here is reminiscent of Wordsworth's self-examination of poetic vocation that would find its fullest expression in The Prelude (posthumously published in 1850).

In addition, Baillie recounts the origins of her career as a dramatist, including seeing a play for the first time, staging scenes for school friends, family, and servants, and reading Bell's British Theatre (1776-8). Her later theories of drama are mapped onto these early experiences as her first play is written 'following simply my own notions of real nature' and an audience's

Joanna and Agnes Baillie provide brief accounts of their memories of former generations written at the request of their nephew, William Baillie. He was allegedly intending to write a short life of his aunt after her death, but there is no evidence that he did so. Slagle, Joanna Baillie: A Literary Life, p. 294.

${ }^{35}$ Joanna Baillie, 'Memoirs Written to please my Nephew William Baillie' (1835), Wellcome Library, MS 5613/68/1-6. All subsequent quotations are from this manuscript.

${ }^{36}$ Linda H. Peterson, Becoming A Woman of Letters: Myths of Authorship and Facts of the Victorian Market (Princeton: Princeton University Press, 2009), p. 7.

${ }^{37}$ Joanna Baillie, Plays on the Passions, ed. Peter Duthie (Ontario: Broadview, 2001), p. 80; See also Duthie, 'Introduction', p. 45. 
emotional response is prized above all. Her development as a poet is located more firmly within a familial context as the inspiration of her aunt-in-law, the poet Anne Hunter, who 'used to read to me every new composition as it came from her pen'. Early poetic experiments, including her poem 'Winter Day' written in blank verse, lead Baillie to 'believe that I possessed some genius'.

Yet Baillie moves beyond a narrative of inspiration and poetic genius to chart the challenges and exhilaration of engaging with the literary marketplace and its professional networks (in which Berry is included). Baillie suggests that familial support was integral to developing her literary confidence and Matthew Baillie is identified as an early 'friendly Critic'. But recognition solely from within the familial sphere is regarded as working 'in the dark' and publication of Plays on the Passions only comes through the encouragement of outsiders. Berry is part of this narrative and identified as an ambassador for Baillie's early work, mirroring Berry's self-construction in her Journal and reminding us of a friendship forged initially as an interaction between an influential woman of letters and an aspiring writer. Commenting on the anonymous publication of Plays on the Passions, Baillie notes:

As my name was entirely concealed I sent no copies of the book to any of my own friends, but to some literary persons, who might perhaps if they liked it, mention it to others. None of those literary persons, as far as I know, took any notice of it but Miss Berry, who saw much company at her house and spoke in the highest terms of it to every body. To her zeal in the cause I have always felt myself to be a debtor.

In these dialogic autobiographical texts, Berry is therefore positioned simultaneously as literary agent, executrix, reader, and extended family member.

Baillie shows an acute awareness in retrospect of how the reception of her work was shaped by wider cultural responses to women dramatists. At a distance of over thirty years, Baillie rehearses the original preface to Plays on the Passions to offer a defence against objections raised by the critical establishment while also recalling the initially positive reception the work received before her (female) identity was revealed. ${ }^{38}$ She remarks that 'the discovery of the hitherto conceald $[s i c]$ Dramatist being not a man of letters but a private gentlewoman of no mark or likelihood, turned the tide of publi[c] favour, and then influential critics and Reviewers from all quarters North \& South, attacked the intention of the work'. Her early career is characterised as the 'brightest part', but she does not wholly subscribe to a narrative of decline,

${ }^{38}$ Baillie's defence seems to particularly write back to Francis Jeffrey's notorious attack on Plays on the Passions in the Edinburgh Review 4 July (1803), pp. 269-86. (See Duthie, Plays on the Passions, p. 429). 
reminding us of the 'generous encouragement' she subsequently received from Sir Walter Scott which inspired her ongoing project of Metrical Legends: 'that my endeavours have not been in vain, my having not long since in my old age composed a Metrical Legend of that admirable Indian Begum [...] is a pretty strong proof'. Characteristically, success is measured in critical esteem and an enduring relationship with her readership rather than monetary gain.

There is no closure to these autobiographical reflections, but Baillie ends with a rehearsal of the importance of family, her Scottish childhood, and the potential for the imagination in the small, the everyday, and the familiar. This is a position compounded by the reflections with which Baillie closes the fragment that evoke her nephew's presence by her side in the sublime landscape of Switzerland. Like many Romantic travelers before her, more well-known for their accounts of Mont Blanc, Baillie acknowledges its 'sublime appearance' and recalls a moment on the mountain from which she beheld a 'Hall of Clouds'. But her response to Switzerland is ambivalent, for she asserts enigmatically that because her mind was 'occupied with anxious thoughts' she 'did not carry home' all that she might 'to add to the indwelling treasures of my heart'. To conclude her 'Recollections', she ultimately turns away from Mont Blanc to 'the clouds seen in my youthful days floating' across the mountains of Scotland, described in highly Wordsworthian terms as 'my chief store of mountain-Ideas' which 'continued so through life'. From this vantage point of later life, Baillie therefore engages with and, in some cases, contests circulating discourses of Romantic genius. The imagination is grounded in a sense of home and landscapes of the past, while authorship emerges from a network of influences and assistance (personal, familial, and professional) which she seeks to record. These fragments that address a friend and nephew, and are bound together through intertextual reference, therefore seem eminently suited as an autobiographical mode that foregrounds collaboration and personal and professional relationships over individualized achievement.

\section{Writing in Late Life}

Paralleling Berry's role in these late life autobiographical projects, Baillie's contribution to Berry's career in old age also seems to have involved encouragement from behind the scenes. The planned publication by Richard Bentley of a sixth edition of Horace Walpole's letters which appeared in 1840 prompts Berry to consider writing an advertisement to the work. Providing a portrait of Walpole around forty years after his death inspired anxiety, but Baillie's view is unequivocal:

Undoubtedly a volume of Lord Orford's Letters, with the addition of those addressed to yourself, require a notice from your pen, and it will, I am 
sure, be well done, though you say something about being $d r y$ as a stick, which I hope is only a figure of speech more humble than applicable. Do not in the fear of saying too much say too little - a fault you have (unlike other modern writers) frequently committed. (Berry, Extracts, III: p. 442)

Berry seems to have taken the advice to heart, writing back in her advertisement to former editors and biographers of Walpole, especially Thomas Babington Macaulay who had launched a scathing attack on Walpole in The Edinburgh Review in 1833. Furthermore, in signing the 'Advertisement' 'M B.', Berry moves closer at this late stage in her career to direct acknowledgement of authorship. From the perspective of female ageing, it is striking that she claims authority as an old woman, the pen 'forced' into her 'feeble and failing hand' to contest the 'giant grasp' of Macaulay whose portrait of Walpole was 'entirely and offensively unlike the original'. She defers to Macaulay as a pre-eminent writer and critic of his age but reminds him of the limits of his knowledge in comparison to the longlived woman writer. His view of Walpole is mistaken not only because he has 'no acquaintance with his subject' but also because he is removed 'from the fashions, the social habits, the little minute details, of the age to which Horace Walpole belongs, - an age so essentially different from the business, the movement, the important struggles, of that which claims the critic as one of its most distinguished ornaments. ${ }^{39}$ Berry suggests that 'by the "painful pre-eminence" of age' she remains 'the sole depository', able to offer a gift to literary posterity in the accuracy and intimacy of her view of writers of a previous generation (Berry, 'Advertisement', p. xx). But, at the same time, she connects herself to nineteenthcentury literary networks by asserting her personal friendship and admiration for Macaulay, a writer who was a regular member of her salon.

Berry's ability to simultaneously imagine herself as a member of the literary past, present, and as a shaper of future tastes, is a reminder that, contrary to some constructions of the older woman writer, ambition did not decline for Berry or Baillie in old age. Contemporaries also recognised the value of Berry's longevity, for on the publication of her complete works in 1844 at the age of eighty-one, The London Quarterly Review noted that Berry had 'experienced and enjoyed the pleasures of fashionable as well as literary intercourse more and longer than any living author' and was therefore authorised to act as 'the historian of society in her own as well as in former periods. ${ }^{40}$ The publication of the complete works also prompted an intriguing exchange between Berry and Baillie, indicative of their continuing concerns regarding critical reputation. Baillie wrote to Berry on 16 October 1844 suggesting that if she 'were much given to envy' she should

39 Mary Berry, 'Advertisement', The Letters of Horace Walpole, 6 vols. (London: Richard Bentley, 1840), VI: p. ix.

40 The London Quarterly Review, March (1845), p. 256. 
envy Berry 'that a clever knowing-in-the-trade bookseller calls for permission to reprint your works' for 'on what spot of the earth lives that book-seller who would now publish at his own risk any part of my works?'. Berry responds:

Why, what a goose you are! - (that ever I, M. B., should dare to call Joanna Baillie a goose!) But don't you see that 'a clever knowing-in-the trade bookseller' reprints trifles made for a drawing-room table and the talk of the day, and not works written for posterity and to take their place in the small band of real poets who have adorned our country. There you will flourish ever green, and will rise in importance as you recede from the present generation. (Berry, Extracts, III: pp. 489-90)

Berry sets her own literary fashionability and contemporary relevance against Baillie's longevity in a language similar to her public endorsement in Social Life in England and France. Once again she couples Baillie with Byron and, in this case, also with Shakespeare and suggests that Baillie's literary fortunes will find posthumous fulfillment. She implicitly expresses anxieties about her own future obsolescence and lack of enduring fame in the process, but nonetheless reasserts her role as a discriminating literary critic.

Despite her fears, Baillie continued publishing into late life, including The Complete Poetical Works of Joanna Baillie published in Philadelphia by Carey \& Lea in 1832 (indicative of her success in America), ${ }^{41}$ Dramas in 1836, Fugitive Verses in 1840, and The Dramatic and Poetical Works of Joanna Baillie, constructed by Baillie for her heirs in 1851 and appearing in the months before her death. These editions provided further opportunities for shaping her past career in prefaces that enabled a more public articulation of her autobiographical 'Recollections' and were coloured by her sense of longevity. Baillie's literary endurance is a thread also taken up by reviewers as Fraser's Magazine noted that Dramas 'awakened that long dormant eagerness of curiosity with which we used to look forward to the publication of her volumes, in those remote days when Wordsworth was yet unknown, and the first faint beams of the genius of Walter Scott had only shewn themselves in a few and scattered miscellaneous poems. ${ }^{\prime 2}$ The same rhetoric is in evidence in the preface to Fugitive Verses in which Baillie gathered together many of her previously published poetic works. She recontextualises her poems in a past literary landscape, reminding us that 'when these poems were written [...] of all our eminent poets of modern times, not one was then known. Mr. Hayley and Miss Seaward [sic],

${ }^{41}$ Writing to Berry on the publication of her complete works in America, Baillie notes 'I am right proud of my book, tho' it is as ugly a thing to look at on the outside as ever lay upon a table'. Collected Letters of Joanna Baillie, I: p. 174.

${ }^{42}$ Fraser's Magazine, February (1836), p. 236. 
and a few other cultivated poetical writers, were the poets spoken of in literary circles. ${ }^{43}$ In Fugitive Verses, she also asserts the importance of female literary networks for inspiring publication, indicating that it was Barbauld's selection of some of her early poems for republication at a moment when these works had otherwise 'gradually faded from my thoughts' that in part encouraged her own determination to republish (Baillie, Fugitive Verses, p. viii).

The reference to Barbauld is a reminder that Baillie and Berry were conscious of their position within a broader network of long-lived female authors whose careers were enduring into the nineteenth century. Maria Edgeworth (17681849), close friend to Baillie from 1813, is praised in Baillie's letters to Margaret Holford Hodson (1778-1852), a fellow writer who Baillie suggests took a 'Sisterly interest' in her literary career (Baillie, Letters, II: p. 666). ${ }^{44}$ On the news that Edgeworth was writing a new novel Helen, published in 1834 when Edgeworth was in her mid-sixties, Baillie hopes 'it will not diminish her fame' (Baillie, Letters, II: p. 647). Despite the anxiety that publication of new works in late life threatens to 'diminish' past successes, Baillie was able to happily report on reading the novel that Edgeworth's 'powers have not been weakened by age, and this all her friends rejoice to see. ${ }^{45}$ However, Baillie's verdict on the late works of Frances Burney, whom she met only once (Slagle, A Literary Life, p. 220), was considerably less supportive of the ageing woman writer and more in line with the ageism of Burney's reviewers. Baillie acknowledges that there is some pleasure to be had in the accurate portraits of the past in Memoirs of Dr Burney (1832), but concludes 'What a strange stile she has acquired in her old age, after writing so admirably well in her youth!' (Baillie, Letters, II: p. 641). The posthumous publication of Burney's Diary and Letters in 1842 prompts further comment, perhaps influenced by Baillie's anxiety expressed elsewhere that public tastes in this period privileged 'scandal \& biography' over poetry (Baillie, Letters, II: p. 682). 'It is curious how eagerly people enter into all the detail of her life after she has been for so many years nearly forgotten and the interest of her novels so much superceded [sic] by a succession of similar works nearly as popular, some of them more so than hers' (Baillie, Letters, II: p. 714). Baillie's contrasting responses to Edgeworth and Burney, while informed by friendship, are also consistent with Looser's insight that 'Edgeworth performed the role of "old woman novelist" far more conventionally than did Burney, which in the

\footnotetext{
${ }^{43}$ Joanna Bailie, Fugitive Verses (London: Edward Moxon, 1840), p. ix.

${ }^{44}$ Edgeworth, likewise, found solace in her friendship with Baillie in late life, noting in her correspondence in 1830 following a visit: 'It has been a great pleasure to me to feel myself so kindly received by those I liked best years ago [...] when not only the leaves of the pleasures of life fall naturally in its winter but when the great branches on whom happiness depended fall'. Maria Edgeworth, Letters from England, 1813-1844, ed. Christina Colvin (Oxford: Clarendon Press, 1971), p. 442.

${ }^{45}$ Quoted in Slagle, Joanna Baillie: A Literary Life, p. 212.
} 
short term contributed to the former's greater success as a late-life author' (Looser, Women Writers, p. 27). Berry likewise enables us to trace interactions between women writers who crossed the borders of the Romantic/Victorian period and feature in each other's life writing. She makes a brief, tantalising appearance in the Memorials of the Life of Amelia Opie (1854) published after Opie's death in 1853 at the age of 84. Allegedly, the two women met at the Great Exhibition in 1851 and Opie playfully challenged her fellow octogenarian to a chair race. ${ }^{46}$

In addition to these intragenerational connections, Baillie and Berry both demonstrate a commitment to intergenerational sociability which worked to challenge their potential dismissal as relics of the past. This is particularly evident in their continued participation in the literary culture of the period through reading, writing, and in their personal friendships with younger authors. In addition to Berry's combative engagement in print with Macaulay over the reputation of Walpole, she continued to assert her role as a critic in her salon able to comment on writers of an earlier era and connect to the next generation. This is exemplified in an anecdote recalled by Kate Perry (friend to Thackeray) around 1849 when Berry allegedly surprised the company by claiming that she had never read Jane Austen's novels until someone lately had lent them to her. Perry states:

But she could not get on with them; they were totally uninteresting to her - long-drawn-out details of very ordinary people, and she found the books so tedious that she could not understand their having obtained such a celebrity as they had done. 'Thackeray and Balzac', she added (Thackeray being present), 'write with great minuteness, but do so with a brilliant pen.' ${ }^{4}$

Such a declaration seems entirely consistent with Berry's commitment to attaching herself to literary modernity, flattering Thackeray, who had recently published Vanity Fair, and asserting her preference for a Victorian novelist over an author regarded as her contemporary who had been dead more than thirty years.

Likewise, Baillie shared Berry's desire to connect to the next generation, evident in her friendships with the children of celebrated Romantic poets. These included Dora Wordsworth (whose father she had met in 1808) and Hartley Coleridge, who composed a poem in which Baillie is commended for her courage in confronting authorship in old age as a poet who 'yet delights to weave the moral rhyme, / Nor fears what is, should dim what thou hast been' (Slagle, A Literary Life, p. 275). Baillie's friendship with Anna Jameson

\footnotetext{
${ }^{46}$ Cecilia Lucy Brightwell, Memorials of the Life of Amelia Opie (London: Longman, Brown and Co, 1854), p. 389.

${ }^{47}$ Lewis Melville, The Berry Papers (London: John Lane, 1914), p. 438.
} 
(1794-1860), glimpsed in their correspondence in the early 1840s, offers a rich example of an intergenerational literary friendship between women. In her warm and familiar letters, Baillie adopts the persona of the older woman writer and identifies Jameson with the literary present. ${ }^{48}$ She asks Jameson to apologise on her behalf to a gentleman who has asked her to write for a periodical publication because 'I am too old now to write any thing and have always declined similar proposals'. Yet she retains her interest in the current literary market, wishing to exploit Jameson's position 'so much among literary people' to help a friend attempting to secure a review in the Athenaeum (Baillie, Letters, II: p. 1027). Jameson provides Baillie with recent publications and the women exchange views on developments in literary taste, in these "giddy-paced times". Such conversations prompt Baillie to reflect on her place in literary history and thank Jameson for her high regard, noting:

I have for many years past been so completely put out of sight, that nothing but great partiality can ever hope more (more) for me than a place in the corner of some great Library that would not be reckoned quite complete if any books that ever had any considerable reputation were wanting. (Baillie, Letters, II: p. 1028)

Baillie's expression of modesty and humility is underlined here by a quiet confidence in her own significance, transmitted to Jameson, a writer 'so much among literary people'.

\section{Literary Afterlives}

Baillie and Berry died within a year of one another in 1851 and 1852 respectively. The perceptions of both by the mid-nineteenth century, as expressed by editors, biographers, obituary writers, and reviewers, illuminate interactions between the Victorians and their Georgian ancestors and provide insight into responses to older women writers in the period. The preface to the second edition of The Dramatic and Poetical Works of Joanna Baillie (1851) offered an opportunity for a posthumous biographical portrait of the author written by her descendents which, alongside numerous obituaries, had an enduring impact on Baillie's reputation. These accounts drew on Baillie's unpublished autobiographical works for their stock of anecdotes, but emphasised childhood and family over the more thorny issues these memoirs addressed such as professional authorship, women's encounters with the critical establishment, and literary fame. Berry is barely mentioned and instead family relations and male friendships are privileged,

${ }^{48}$ Baillie's letters indicate that she was also visited by Jameson's friend and contemporary, Harriet Martineau (1802-76), during this period. (Baillie, Letters, II: p. 1033). 
particularly Baillie's attachment to Sir Walter Scott. The dominant thread in these portraits is Baillie's commitment to 'retirement from the first hour to the last' and a 'domestic circle of the highest moral purity', with her 'seclusion' apparently intensifying in late life. ${ }^{49}$ As The Illustrated London News expressed it:

Though Miss Baillie's fame tended greatly to draw her into society, her life was passed in retirement. It was pure and moral in the highest degree, and was characterised by the most consummate integrity, kindness, and active benevolence. She was an instance that poetical genius of a high order may be united to a mind well regulated, able and willing to execute the ordinary duties of life in an exemplary manner. ${ }^{50}$

In her study of the Victorian lives of Romantic women writers, Lisa Vargo suggests that in biographical accounts 'Romantic writers are made to echo notions of Victorian propriety' yet 'at the same time some telling discords suggest that female literary authority cannot be so easily written to resonate with a finer tone of passivity'. ${ }^{51}$ Such tensions proliferate in these constructions of Baillie. The exemplary woman writer whose life of domestic retirement ensured that literary 'fame' and 'poetical genius' proved no distraction from 'the ordinary duties of life' coexists with acknowledgements of Baillie's membership of brilliant literary and scientific circles and her ability to attract numerous admirers from Europe and America, especially in late life.

This narrative of retirement is central to Lucy Aikin's 'Recollections of Joanna Baillie' of 1864 that offers a record of Aikin's friendship with Baillie from their first meeting in Hampstead when Aikin was a young girl. Aikin had already established a model for the lives of Romantic female authors in the memoir of her aunt, included in Works of A. L. Barbauld in 1825. Implicitly reminding us of this, and evoking her authority as an older woman writer herself by this point, Aikin begins by asserting that it has been my privilege to have had more or less of personal acquaintance with almost every literary woman of celebrity who adorned English society from the latter years of the last century nearly to the present time ${ }^{52}$ Modesty, family duty, and piety are central to Aikin's account as Baillie is again established as a model worthy of emulation by the next generation.

49 The Dramatic and Poetical Works of Joanna Baillie, $2^{\text {nd }}$ edn. (London: Longman, Brown, Green, and Longmans, 1851), pp. v, xii.

50 The Illustrated London News, 1 March (1851), p. 180.

${ }^{51}$ Lisa Vargo, 'A Finer Tone: Victorian Lives of Mrs. Barbauld and Mrs. Shelley', in Romantic Echoes in the Victorian Era, ed. Andrew Radford and Mark Sandy (Aldershot: Ashgate, 2008), pp. 15-26 (p. 15).

${ }_{52}$ Memoirs, Miscellanies and Letters of the Late Lucy Aikin, ed. Philip Hemery Le Breton (London: Longman, 1864), p. 7. 
Aikin's recollections therefore reveal how Victorian women writers engaged with the generation that preceded them through biography and used the genre to celebrate women's literary achievements, participate in canon formation, establish their critical voices, reflect on models of female authorship, and shape their own authorial identities. A brief survey of Victorian collective biographies in the decades following Baillie's death extends the idea of women's crossgenerational literary networks into these (auto)biographical encounters. Jane Williams in The Literary Women of England (1861) offers a weary assessment of the challenges long-lived writers such as Baillie and Barbauld present for her project of constructing a female literary history.

The different lengths of the lives of the Poetesses, and the extreme longevity of a few, tend, in a chronological survey, to produce a somewhat bewildering, although a just effect, answering to real life, where whole generations do not die off regularly in the order of birth, but certain individuals live on, and become successively cotemporary $[s i c]$ with the second, third, and even with the fourth ranks of population's advancing hosts. ${ }^{53}$

Nonetheless, Williams and her contemporaries took up the challenge in their accounts of Baillie, putting her life into service in defence of female authorship. Her roles as 'daughter, sister, aunt, and grand-aunt', and her 'handiness with the needle', are repeatedly stressed, accompanied on one occasion by the revealing riposte '(hear it all those who must needs believe an authoress "handless")' ${ }^{4}$ Catherine Jane Hamilton's Women Writers: Their Works and Ways (1872) provides a clear example of Vargo's 'telling discords' in the attempt to reconcile Baillie's 'semi-masculine nature', ambition, and courage in youth, with the multiple portraits of her in late life as a 'white-haired old lady' in a 'little old lace cap that encircled her peaceful face.'.5 Like the earlier posthumous narratives, Berry is largely absent in these accounts, although Sarah Tytler and Jean L. Watson's The Songstresses of Scotland (1871) is a notable exception, with space devoted to Berry and Baillie's friendship (portrayed in sentimental terms) and Berry's role in publicising Plays on the Passions. Excerpts from Berry's Journal (which had been published seven years previously) are also incorporated into this narrative of Baillie's life.

While Baillie was a recurrent figure in nineteenth-century collective biographies of women writers, Berry is a notable absence. Working in the genres

53 Jane Williams, The Literary Women of England (London: Saunders, Otley, and Co, 1861), p. 553.

${ }^{54}$ Sarah Tytler and Jean L. Watson, The Songstresses of Scotland, 2 vols. (London: Strahan and Co, 1871), II: pp. 209, 190-1.

55 Catherine Jane Hamilton, Women Writers: Their Works and Ways, 2 vols. (London: Ward, Lock, 1872), I: pp. 111, 130-1. 
of history and biography was inconsistent with Victorian collective biographers' enthusiasm for poetesses and novelists and Berry posed a challenge to nineteenth-century models of the woman writer. Instead, her appearance in print in the second half of the nineteenth century was through her Journals, which she arranged to be edited and posthumously published by the Whig hostess, Lady Theresa Lewis as Extracts of the Journals and Correspondence of Miss Berry from the Year 1783 to 1852 (1865). Given Berry's preference for semi-anonymous authorship during her lifetime, her determination to see her Journals in print is intriguing. It suggests an awareness of the cultural value of her personal reflections and social connections and a desire to perpetuate her role as a critic and social historian of the era beyond her own lifetime. At the same time, posthumous publication enabled her to avoid the charge of egotism that publishing while still alive would inevitably have provoked. In contrast to Baillie's association with domestic retirement, Lewis's biographical introduction to the edition positions Berry as 'a centre round which beauty, rank, wealth, power, fashion, learning, and science were gathered' (Berry, Extracts, I: p. xiii). She echoes Berry's self-portrait in late life as a woman who provided a valuable link to the past at the same time as she forged connections to the next generation and shaped future literary directions. The incidents recorded in her Journal are 'the stepping-stones that help us to remount the stream of Time', yet Lewis also asserts that in Berry's 'old age, the loved and admired of the fastidious Horace Walpole won the hearts of the grandchildren and great-grand children of the friends of her youth' (Berry, Extracts, I: pp. xvii, xiv). The same dynamic is at work in a poem by Richard Monckton Milnes published in The Times, following the death of the Berry sisters in 1852, which simultaneously connects them to the onward generation and establishes their talismanic relationship with the past:

While others in Time's greedy mesh

The faded garlands flung,

Their hearts went out and gathered fresh

Affections from the young.

Farewell, dear ladies! in your loss

We feel the past recede,

The gap our hands could almost cross

Is now a gulf indeed. ${ }^{56}$

On the Journal's publication, enthusiastic reviewers echoed this characterisation of Mary and Agnes Berry as 'connecting links, ${ }^{57}$ while the Journal was purported to offer 'a perfect picture of the society of the last century, with most interesting

${ }^{56}$ Quoted in Berry, Extracts, III: pp. 519-20.

${ }^{57}$ Notes and Queries, 7 October (1865), p. 299. 
gleams of its current history' ${ }^{58}$ In a more elastic approach to historical accuracy, Thackeray in his American lectures on The Four Georges in 1855-6 referred to an old woman whose life spanned the reigns of George I to George III (identified by Ian Haywood as Berry), noting 'I often thought as I took my kind old friend's hand, how with it I held on to the old society of wits and men of the world' 59 Despite these celebrations of Berry's significance, she has struggled to secure her place in literary history. However, by attending to her interactions with Baillie, we are able to see her contributions as a shaper and recorder of literary history, and participant in the sphere of letters, into the nineteenth century.

The case of Berry and Baillie suggests the value of taking up Schellenberg's invitation to 'pay attention to whole career trajectories' (Schellenberg, p. 19) in order to reconsider our understanding of female literary networks in the Romantic period and reframe established critical narratives of the careers of individual authors. Friendship and collaboration fostered these women's writing lives over a fifty year period and in their exchanges we glimpse revealing moments of anxiety and agency, particularly in relation to the challenges and opportunities of continuing to publish into late life. Situating them within wider circles of friendship highlights the connections they forged with other long-lived authors, and illuminates their deliberate attempts to connect to the following generation and secure their future critical reputations. Identifying age as a category of analysis in studies of Romantic literary sociability also enables us to examine intra- and intergenerational connections both within and across traditional literary periods. The life writing of Baillie and Berry therefore provides insight into the ways in which friendship might contribute to the management of a literary career throughout the life course and beyond.

\section{Bibliography}

\section{Printed Works}

Aikin, Lucy. Memoirs, Miscellanies and Letters of the Late Lucy Aikin, ed. Philip Hemery Le Breton. London: Longman, 1864.

Bailey Slagle, Judith. 'Evolution of a Writer: Joanna Baillie's Life in Letters', in Joanna Baillie, Romantic Dramatist: Critical Essays, ed. Thomas C. Crochunis. London: Routledge, 2004, pp. 8-26.

Baillie, Joanna. Fugitive Verses. London: Edward Moxon, 1840.

-. Further Letters of Joanna Baillie, ed. Thomas McLean. Madison: Fairleigh Dickinson University Press, 2010.

—. Plays on the Passions, ed. Peter Duthie. Ontario: Broadview, 2001.

58 The Times review, quoted in Notes and Queries, 4 November (1865), p. 383.

59 William Thackeray, Miscellanies: The Four Georges, 5 vols. (Boston: Fields, Osgood, 1869), IV: p. 3; Ian Haywood, 'Thackeray, Mary Berry, and The Four Georges', Notes and Queries, 30:4 (1983), p. 299. 
-. The Collected Letters of Joanna Baillie, ed. Judith Bailey Slagle, 2 vols. Madison: Fairleigh Dickinson University Press, 1999.

Berry, Mary. 'Advertisement', The Letters of Horace Walpole, 6 vols. London: Richard Bentley, 1840.

-. Extracts of the Journals and Correspondence of Miss Berry from the Year 1783 to 1852, ed. Lady Theresa Lewis, 3 vols. London: Longmans, Green and Co, 1865.

-. Social Life in England and France, from the French Revolution in 1789, to that of July 1830. London: Longman, Rees, Orme, Brown, and Green, 1831.

Brightwell, Cecilia Lucy. Memorials of the Life of Amelia Opie. London: Longman, Brown and Co, 1854.

Burroughs, Catherine B. Closet Stages: Joanna Baillie and the Theater Theory of British Romantic Women Writers. Philadelphia: University of Pennsylvania Press, 1997.

Burwick, Frederick. 'Joanna Baillie, Matthew Baillie, and the Pathology of the Passions', in Joanna Baillie, Romantic Dramatist: Critical Essays, ed. Thomas C. Crochunis. London: Routledge, 2004, pp. 48-68.

Carhart, Margaret. The Life and Work of Joanna Baillie. North Haven: Archon Books, 1970.

Crochunis, Thomas C., ed. Joanna Baillie, Romantic Dramatist: Critical Essays. London: Routledge, 2004.

Duckling, Louise. 'Coming Out of the Closet and Competing with John Anybody: The Bold World of Joanna Baillie', British Women and the Intellectual World in the Long Eighteenth Century, ed. Teresa Barnard. London: Routledge, 2016.

Edgeworth, Maria. Letters from England, 1813-1844, ed. Christina Colvin. Oxford: Clarendon Press, 1971.

Feldman, Paula R. British Women Poets of the Romantic Era: An Anthology. Baltimore: Johns Hopkins University Press, 2000.

Gullette, Margaret Morganroth. Aged by Culture. Chicago: University of Chicago Press, 2004.

Hamilton, Catherine Jane. Women Writers: Their Works and Ways, 2 vols. London: Ward, Lock, 1872.

Haywood, Ian. 'Thackeray, Mary Berry, and The Four Georges'. Notes and Queries, 30:4 (1983).

Levy, Michelle. Family Authorship and Romantic Print Culture. Basingstoke: Palgrave Macmilllan, 2008.

London, Bette. Writing Double: Women's Literary Partnerships. Ithaca: Cornell University Press, 1999.

Looser, Devoney, ed. The Cambridge Companion to Women's Writing in the Romantic Period. Cambridge: Cambridge University Press, 2015.

-. Women Writers and Old Age in Great Britain, 1750-1850. Baltimore: Johns Hopkins University Press, 2008.

Melville, Lewis. The Berry Papers. London: John Lane, 1914.

Peterson, Linda H. Becoming A Woman of Letters: Myths of Authorship and Facts of the Victorian Market. Princeton: Princeton University Press, 2009. 
Sanders, Valerie. The Private Lives of Victorian Women: Autobiography in NineteenthCentury England. Hemel Hempstead: Harvester Wheatsheaf, 1989.

Schellenberg, Betty A. The Professionalization of Women Writers in EighteenthCentury Britain. Cambridge: Cambridge University Press, 2005.

Schmid, Susanne. British Literary Salons of the Late Eighteenth and Early Nineteenth Centuries. Basingstoke: Palgrave Macmillan, 2013.

- 'Mary Berry's Fashionable Friends (1801) on Stage'. The Wordsworth Circle (2012).

Slagle, Judith Bailey. Joanna Baillie: A Literary Life. Madison: Fairleigh Dickinson University Press, 2002.

-. 'Sisters - Ambition and Compliance: The Case of Mary and Agnes Berry and Joanna and Agnes Baillie', Woman to Woman: Female Negotiations During the Long Eighteenth Century, ed. Carolyn D. Williams, Angela Escott, and Louise Duckling. Newark: University of Delaware Press, 2010.

Stone, Marjorie and Judith Thompson, eds. Literary Couplings: Writing Couples, Collaborators, and the Construction of Authorship. Madison: University of Wisconsin Press, 2006.

Thackeray, William. Miscellanies: The Four Georges, 5 vols. Boston: Fields, Osgood, 1869.

Tytler, Sarah and Jean L. Watson. The Songstresses of Scotland, 2 vols. London: Strahan and Co, 1871.

Vargo, Lisa. 'A Finer Tone: Victorian Lives of Mrs. Barbauld and Mrs. Shelley', Romantic Echoes in the Victorian Era, ed. Andrew Radford and Mark Sandy. Aldershot: Ashgate, 2008.

Williams, Jane. The Literary Women of England. London: Saunders, Otley, and Co, 1861.

Yallop, Helen. Age and Identity in Eighteenth-Century England. London: Routledge, 2013.

\section{Manuscripts}

Berry, Mary. Letter to Joanna Baillie, 21 Sept 1832. Wellcome Library, MS 5613 $77 / 1$.

'The Berry Papers: Correspondence, Papers and Journals of Mary Berry (17631852), Add MS37758, British Library.

Baillie, Joanna. 'Recollections Written at the Request of Miss Berry' (1831). Royal College of Surgeons, Hunter-Baillie, MS0014/3.

—. 'Memoirs Written to please my Nephew William Baillie' (1835). Wellcome Library, MS 5613/68/1-6.

\section{Periodicals}

Fraser's Magazine

The Illustrated London News

The Times 


\title{
The Female Authors of Cadell and Davies
}

\author{
Michelle Levy and Reese Irwin
}

Trading between 1765 and 1836, the publishing firm Cadell and Davies (C \& D), in its various incarnations, published 'many of the most important and enterprising works of the late eighteenth century'. The firm is especially noteworthy for its publication of several influential female authors of the period, including Frances Burney, Hannah Cowley, Felicia Hemans, Hannah More, Charlotte Smith, Ann Radcliffe, and Helen Maria Williams, to name only a handful of the well-known women they published during this period. This chapter will offer a detailed analysis of the nature of the relationships between $\mathrm{C} \& \mathrm{D}$ and their female authors, by examining the surviving correspondence and the bibliographical history of their publication of women's writing. This method allows for both a quantitative and qualitative assessment of the firm's business practices and women's engagement with the commercial world of print.

Throughout this chapter we use the shorthand of $C \& D$, though in fact the firm operated in a variety of different configurations over its seventy-one years of operation (1765-1836). In 1765 Thomas Cadell, Sr. (1742-1802) became Andrew Millar's partner, taking over the business in 1767. Cadell Sr. published Edward Gibbon's Decline and Fall of the Roman Empire (1776-88) and Samuel Johnson's Lives of the Most Eminent English Poets (1779-81), along with novels by Henry Mackenzie and Tobias Smollet, the poetry of Robert Burns, the legal writing of William Blackstone, and the philosophy of David Hume and Adam Smith. Cadell was an original member of a famous dining club of booksellers which met monthly at Shakespeare Tavern. ${ }^{2}$ His son,

${ }^{1}$ Michael Sadleir, 'Review of The Publishing Firm of Cadell and Davies: Select Correspondence and Accounts, 1793-1836, The Library, 19: 3 (1938), pp. 364-8 (p. 365).

2 Catherine Dille, 'Cadell, Thomas, the elder (1742-1802)', Oxford Dictionary of National 
Thomas Cadell, Jr. (1773-1836), succeeded him in 1793, with Cadell, Sr. choosing William Davies as his son's partner. The new partners located their firm at 141 Strand in London, with Davies managing most of the partnership's affairs until he became ill in 1813. Cadell consequently became more involved with the business and continued to run the firm after Davies's death in 1820, publishing under his own name until he died in 1836.

C \& D's dates roughly mirror those of the Romantic period itself, a period which in turn tracks the huge increase in book publication that commenced in the final third of the eighteenth century. ${ }^{3}$ Although we lack comprehensive data, we know that women made enormous contributions to this increased production, particularly in the genres of fiction and poetry, both important genres on C \& D's lists. In Virginia Woolf's famous formulation, in the later eighteenth century 'a change came about which, if I were rewriting history, I should describe more fully and think of greater importance than the Crusades or the Wars of the Roses. The middle-class woman began to write. ${ }^{4}$ To adapt Woolf to the evidentiary record we now have before us, we might say that the closing decades of the eighteenth century were a critical turning point in the quantitative output of women's contributions to print. ${ }^{5}$ As Judith Stanton observed nearly three decades ago, data on women's entry into print for the period 1660 to 1800 demonstrates that '[t]heir numbers increased at around fifty percent every decade starting in the 1760s' thus 'confirm[ing] what we sense about the history of women writing, that the later eighteenth century saw a structural change in the behaviour of women'. ${ }^{6} \mathrm{C} \& \mathrm{D}$ 's business likewise ends at a transitional moment, both politically, with the beginning of Victoria's long reign, and technologically, with the rise of industrialised print production.

An analysis of $C \& D$ and their engagements with female authors thus provides a useful case study suggestive of larger patterns within the period as a whole. What emerges from our analysis is a different understanding of female literary networks than that described in most of the chapters in this

Biography, (Oxford: Oxford University Press, 2004), online edn., January 2008. Simon Fraser University. 10 December 2013. Web.

${ }^{3}$ Michelle Levy, 'Women and Print Culture, 1780-1830', in The History of British Women's Writing, 1750-1830, ed. Cora Kaplan and Jennie Batchelor, and Jacqueline Labbe (vol. ed.), 5 (Basingstoke: Palgrave Macmillan, 2010), pp. 29-46 (p. 31-2).

${ }^{4}$ Virginia Woolf, A Room of One's Own (London: Penguin, 2004). p. 18.

${ }_{5}^{5}$ Of course, Woolf was mistaken in the claim that middle-class women began to write in the late eighteenth century, as they had been writing for centuries. As we now know, however, they often wrote for manuscript circulation, though even their print record was largely obscured to and thus unknown by Woolf.

${ }^{6}$ Judith Phillips Stanton, 'Statistical Profile of Women Writing in English from 1660-1800', in Eighteenth-Century Women and the Arts, ed. Frederick M. Keener and Susan E. Lorsch (New York: Greenwood, 1988), pp. 247-54 (p. 248). 
book. Here we do not describe networks of women writers, but rather a print network. In particular, the network between C \& D and their female authors may be characterized as a nearly perfect 'star network', with C \& D in the central position, and all of their female authors surrounding them as starbursts, or spokes in a wheel. In this kind of a network, one node (C \& D) is connected to the others, and all other nodes are connected to each other only via $\mathrm{C} \& \mathrm{D}$. Admittedly, we did not investigate relationships between the women themselves (because we searched for letters to/from C \& D), and on a few occasions there are intermediary figures who complicate the model somewhat. However, by and large this network form suggests the centralized position, and power, that male publishers held within a marketplace abundant with female writers seeking to print their works. This star model also mirrors the geographical relationship between C \& D and their female authors, since most women resided outside of the capital, with C \& D occupying their highly central position in the capital, at their Strand address in the literal middle of London. Through our qualitative analysis of the surviving correspondence, we find literary networks organized by both commercial interests and sociable codes of conduct. Women's places within these publishing networks are equally complex, as they were at once autonomous (operating as individual economic agents) and dependent (reliant upon the advice and market sense of their publishers). Often seeking profit, always concerned with reputation, women came to $\mathrm{C} \& \mathrm{D}$ with varying degrees of social and cultural capital and a range of knowledge about the book trades. Their interactions with $\mathrm{C} \& \mathrm{D}$ remind us of their vulnerabilities but also of the regard in which female writers were held, and their centrality to the period's literary print culture.

To date, most attempts to understand women's engagements with print after 1750 have adopted qualitative methods, describing women as individual professional writers who sought remuneration for their work and respect from both lay and professional readers. In a related essay published in 2014, 'Do Women Have a Book History?', one of the co-authors of this essay, Michelle Levy, provides a survey of the history of scholarship on women's professional authorship in the long eighteenth century, and argues for a broader 'understanding of women's engagement with literary culture', in part by examining 'the actual conditions of literary production and dissemination'? That essay includes analysis of a specific case study of women's publishing history of the period, an archive of the correspondence of eighty women, in 172 letters, with four publishing houses, a collection entitled 'Original Letters, collected

Michelle Levy, 'Do Women Have a Book History?', Studies in Romanticism, New Directions in Romanticism and Gender: Essays in Honor of Anne K. Mellor, 53: 3 (Fall 2014), pp. 297-314 (pp. 303-4). 
by William Upcott of the London Institution. Distinguished Women' and held by the British Library. ${ }^{8}$ Here, we develop the claims made in that essay by providing a sequel of sorts, surveying a differently configured collection of letters - largely from women to one publishing house, C \& D.

\section{Methodology}

According to Devoney Looser, 'it is beyond [question] that big data [approaches are] necessary - integral - to our writing better literary histories of this watershed moment for the professional woman writer'. She calls 'for us to think more creatively and collaboratively about new biographical practices', and we would add, bibliographical practices, 'that could emerge for Romantic women writers in concert with big data.' This chapter offers one experiment along the lines Looser suggests, by engaging with evidentiary materials that allow us to perform both a micro- and macro-analysis of women's publishing history.

Of the few attempts to survey women's commercial engagements with print, all are at least twenty years old, and only one (Judith Stanton's) attempts a quantitative approach. ${ }^{10}$ Furthermore, none of these attempts use digital resources, which provide us with unprecedented access to information about women's books from the period. This essay uses 'distant reading' approaches, of the type advocated by Franco Moretti, to move beyond the scope of a small number of professional women writers to focus on the engagements of a larger group of women with their publishers. Our essay examines women's entanglements with their publishers both from near and afar, enabling a fuller understanding of how women's books were produced, marketed, and distributed during the period. We present close and distant reading strategies by carefully attending to individual letters, and by categorising and thus grouping together issues raised in the letters, to provide an overview of the nature of the concerns expressed within the correspondence.

Most of our analysis - both qualitative and quantitative - is focused on a corpus of letters that passed between $\mathrm{C} \& \mathrm{D}$ and their female authors. Letters and other business documents of the firm survive in profusion,

${ }^{8}$ EVELYN PAPERS. Vols. DXIX-DXXII. 'Original Letters collected by William Upcott of the London Institution. Distinguished Women'; $17^{\text {th }}-19^{\text {th }}$ cent. (1824), Add. MS 78686-78689, British Library.

9 Devoney Looser, 'British Women Writers, Big Data, and Big Biography, 1780-1830', Women's Writing, 22: 2 (May 2015), pp. 165-71 (p. 165).

${ }^{10}$ Jan Fergus, and Janice Farrar Thaddeus, 'Women, publishers, and money, 1790-1820', Studies in Eighteenth-Century Culture, 17 (1987), pp. 191-207; Stanton, 'Statistical Profile of Women Writing in English', pp. 247-54; Cheryl Turner, Living by the Pen: Women writers in the eighteenth century (New York: Routledge, 1994). 
although they are diffused across numerous institutions in the US and UK. The publishing house has not been extensively researched beyond Theodore Besterman's collection of selected letters in 1938, which published no letters to or from women. ${ }^{11}$ Besterman's letters not only reflect the lack of status accorded to women writers at the time his book was published; they also reflect the hugely differential survival rates of letters from women to C \& D, as opposed to men.

In researching this project, correspondence and records were transcribed and described at all of the known archives with significant holdings of $\mathrm{C} \& \mathrm{D}$ material: the British Library (BL); Beinecke (BE); Bodleian (BO); New York Public Library (NYPL); National Library of Scotland (NLS); Edinburgh University Library (EUL); Houghton Library (HO); Huntington Library (HL); and the University of Birmingham (UB). These collections hold thousands of letters by men to $\mathrm{C} \& \mathrm{D}$; as an example, 128 folders at the Beinecke hold one of the largest collections of the firm's letters. 111 of these folders contain correspondence to the firm and related documents generated by men; by contrast, only seventeen folders hold letters and documents by women. Furthermore, out of these seventeen folders, most (fifteen) hold material by Charlotte Turner Smith, and contain 140 of her letters; this leaves only two folders with letters from other women to $\mathrm{C} \& \mathrm{D}$ : one contains nine letters from Henrietta Maria Bowdler, and the other has three letters by Charlotte Mary Smith. ${ }^{12}$ In our corpus of letters, culled from these archives, we include a total of 150 surviving letters to and from women and the publishing house, a number that (as we have seen in the Beinecke archive) is dwarfed by the number of surviving letters to and from the publishers and men. Specifically, our corpus includes 141 letters by women, and nine by C \& D to women, written between 1771 and 1845 . In all, our corpus includes forty-seven women sending or receiving letters to or from the firm.

Table 5.1 shows the breakdown of total letters, and total women, by archive. As may be seen, the BL holds the largest collection of letters (fiftyeight), followed by the Bodleian (twenty-eight), Houghton (twenty-eight), and Beinecke (twenty). Fifty of the letters from the BL were collected by William Upcott. Upcott, a librarian and collector, obtained large quantities of correspondence from several London publishers, whom he knew well. The far fewer letters held by other institutions demonstrates the importance of the Upcott collection as a record of women's publishing history.

11 Theodore Besterman, The Publishing Firm of Cadell and Davies: Select Correspondence and Accounts, 1793-1836 (London: Oxford University, 1938).

12 The letter count of Charlotte Turner Smith's letters is from Charlotte Smith, The Collected Letters of Charlotte Smith, ed. Judith Phillips Stanton (Bloomington: Indiana University Press, 2003). p. xxxiii. Other totals are our own. 
Table 5.1: Number of letters / number of women by archive

\begin{tabular}{lcc}
\hline Archive & Total Letters & Total Women \\
\hline BL & 58 & 31 \\
BE & 20 & 2 \\
BO & 28 & 10 \\
NYPL & 1 & 1 \\
NLS & 1 & 1 \\
EUL & 5 & 2 \\
HO & 28 & 7 \\
HL & 6 & 3 \\
UB & 3 & 3 \\
\hline TOTAL & 150 & 47 individual women \\
\hline
\end{tabular}

Figure 5.1 shows the number of letters individual women wrote. As shown, letters from C \& D's most successful female author, Hannah More, dominate these counts, with thirty-six letters from her: twelve (BL); fifteen (HO); and nine (BO). Charlotte Smith comes in a distant second, with fourteen letters - only one of which has been published (Stanton pp. 29-30). Beyond More and Smith, most women in our corpus write fewer than ten letters, and the vast majority write only one or two. In this way, our corpus presents a broad cross-section of women, helping us move beyond the individualising tendencies of literary studies.

As a wide range of women sent and received the letters, from different locations and discussing a wide range of topics, we needed a quantification method to gain a clearer picture of women's concerns and requests. To capture this data, we created a database for all of the correspondence, including all information in the letters (such as dates, names, place), and transcriptions. From this data, we can present some basic demographic information about these women. Of the forty-seven women, the primary occupations of thirty are, unsurprisingly, as writers, though many women have multiple occupations. Two are artists, and the other known women are designated only in familial/ social terms (as wives, sisters, daughters, etc.). Most of the letters - 117 of the 141 total - were written from inside Britain, and came from forty-three women; of these, eighty-three were written from outside of London (by twentyfour women) and thirty-four letters were written from London (by twenty-two women). Ten of the letters were written outside of Britain, and came from four women: seven letters from Italy (six from Hester Lynch Piozzi, one from 


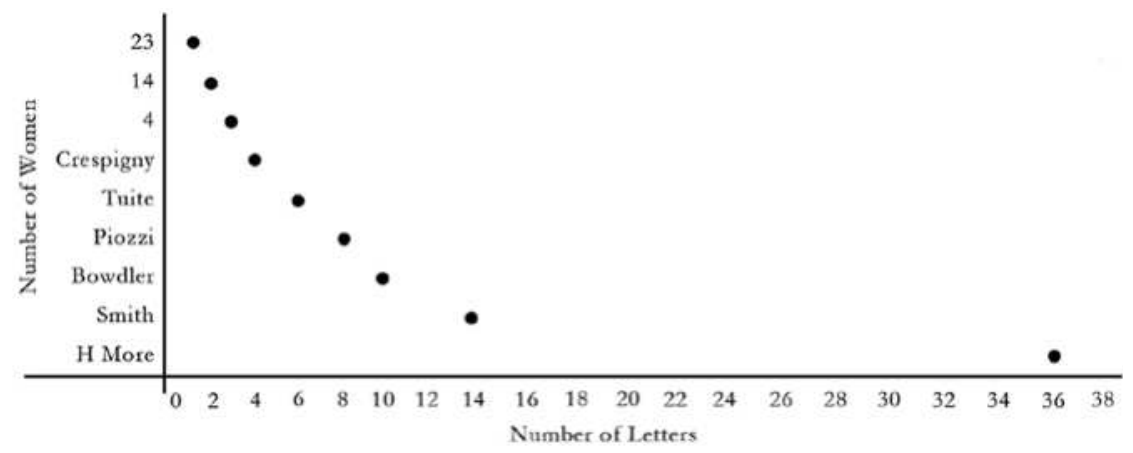

Figure 5.1: Number of women / number of Letters

Maria Gisborne); three from Ireland (two from Elinor Whitelaw, one from Margaret Riollay); the remaining fourteen letters have an unknown location.

We also incorporate quantitative bibliographical data about C \& D's publication of female authors. We have compiled an extensive bibliography of women's publications with the publisher to enable a fuller understanding of how the firm produced, marketed, and distributed women's books in the period. ${ }^{13}$ We included all known books that a woman authored, translated, or edited. Between 1767 and 1836, C \& D published 180 titles by eightytwo women (including five 'by a lady' or similarly gendered signature). The left-hand side of Figure 5.2 demonstrates that most women - fifty-four in the bibliography (or 66 per cent of the total number of women) - published only one work. There is a significant jump to the next data points, with nine women publishing two titles, nine publishing three, six publishing four, and one woman publishing five; we can see how frequently women made brief appearances in print. ${ }^{14}$ These numbers bear comparison to those for women's poetry generally:

${ }_{13}$ This bibliography was compiled by examining the following sources: English Short Title Catalogue, [online] Available at: <estc.bl.uk>; Jackson Bibliography of Romantic Poetry, (2016), [online] Available at: <jacksonbibliography.library.utoronto.ca>; Eighteenth-Century Collections Online, Gale [online] Available at: <gale.com/primary-sources/ eighteenth-century-collections-online>; Andrew Strahan and Thomas Cadell, The following valuable books are printed for A. Strahan and T. Cadell, in the Strand. 1788-1793 (London: A. Strahan and T. Cadell, 1788-1793), in Eighteenth Century Collections Online. Gale. Simon Fraser University. 4 April 2016; Cadell and Davies, The following valuable books are printed for T. Cadell, Jun. and W. Davies (Successors to Mr. Cadell) in the Strand, 1796; 1797 (London: Cadell and Davies, 1796; 1797), in Eighteenth Century Collections Online. Gale. Simon Fraser University. 4 April 2016.

${ }_{14}$ The business model, at least for women, seems to contradict Cadell, Sr.'s comments to Gibbon in 1787: 'I had rather risk my fortune with a few such Authors as Mr Gibbon, Dr Robertson, D Hume ... than be the publisher of a hundred insipid publications'. 
[O]f the 714 known poets in Jackson's ... Romantic Poetry by Women: a bibliography, 1770-1835, 490 women, or 68 per cent of the cohort, published only a single volume of verse; a further 112 women, or 16 per cent, published two books of verse. According to Jackson's data, a full 84 per cent of all women poets in the Romantic period printed no more than two separate poetry titles. By contrast, only 43 women, or 6 per cent, wrote five or more titles, and only eight, or 1 per cent, wrote more than ten ... (Levy, 'Print Culture', p. 39)

C \& D's female authors fare almost identically to those publishing poetry, with 66 per cent $(C \& D)$ to 68 per cent (all women's poetry) of women publishing only a single title. We also have nearly identical figures at the other end of the spectrum, with a total of only six women (Brooke, Cowley, Williams, Hemans, Smith, and More) - or 7 per cent of the total - writing five or more titles. To the far right of Figure 5.2, we find the most prolific woman, Hannah More, with a staggering twenty-seven titles. These statistics suggest a repeated pattern across women's publishing history: a large majority (66-68 per cent) of women entered print briefly, and a very small minority (6-7 per cent) were exceptionally prolific.

In Figure 5.3, we consider the twenty-eight (34 per cent of women) whose works went into multiple editions. These women published eighty-six titles; in total, C \& D published 494 editions of women's works. More's enormous success is readily apparent in Figure 5.3. C \& D published a staggering 178 editions of the twenty-seven titles by More, or thirty-six percent of the total 494 editions. ${ }^{16}$ Understood in these terms, More's strategic importance to the firm is evident. Figure 5.3 also demonstrates that $\mathrm{C} \& \mathrm{D}$ had measurable success with a range of female authors (similar to those in Figure 5.2, with Smith, Brooke, Cowley, Williams, and Burney taking the lead) - women who wrote titles that reached multiple editions. ${ }^{17}$ We also see a long tail, with most women (forty of eighty-two, or nearly half) with works that were never reprinted. In Figure 5.4,

${ }^{15}$ See also Kirstyn Leuner, 'Romantic Women Writers and The Stainforth Library: "Making Women Writers Count” (NASSR 2016)', Digital Romanticisms, (2016), n.p., in which she states: 'Of these 940 authors with publications in the Romantic era, those with the most titles in the [Stainforth] library include Hannah More (99), Hannah Cowley (67), Elizabeth Inchbald (67), Susannah Centlivre (42), Felicia Hemans (36), Elizabeth Rowe (31), Anne Plumptre (26), Anna Seward (23), and L. E. L. (Maclean) (22)'.

${ }^{16}$ There is some evidence that some of the edition sizes were quite large: On 30 October 1825, a member of the firm informs her 'that it was requisite to put to Press again the "Spirit of Prayer" and requested to know whether she had any corrections to make - Suggested that the same number should be printed as before viz: 1500'; Letter from Hannah More to Thomas Cadell, Jr, 30 October 1825, Houghton Library, MS Hyde 69, folio 30, Cambridge, United States of America.

${ }^{17}$ What we see with the disappearance of Hemans from Figure 5.2 has been noted in 


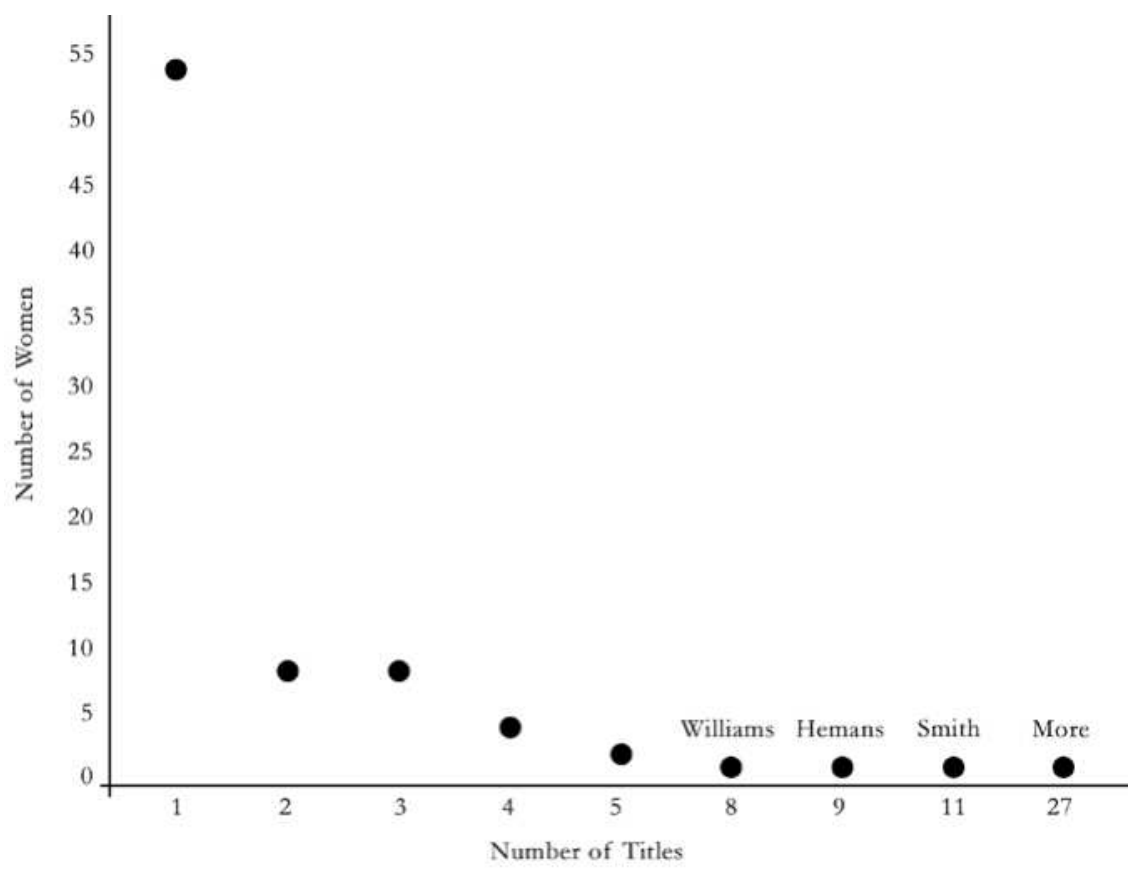

Figure 5.2: Number of titles, by female authors, published by Cadell and Davies between 1767 and 1836

we see how important the major genres of poetry and fiction were to $C \& D$, another way in which the firm's activities are broadly representative of the literary marketplace as a whole. We also realize that the exceptionally prolific authors (Brooke, Cowley, Williams, Hemans, Smith, and More) are also authors whose works go into many editions.

Within this complex ecology, the need for variation in economic arrangements between different women becomes apparent, and we see these differences borne out in the correspondence. We see how C \& D treat exceptional women - those with proven records of success or with works deemed worthy of investment - in the publishers' willingness either to pay for the copyright outright or to share profits. We also see how women themselves advocate for their worth. Other women without a history in print have far less bargaining power, and $\mathrm{C} \& \mathrm{D}$ show themselves unwilling to take risks unless their costs and time are covered. For the category in between, a range of economic options were available, though as we shall see the publishers were generally conservative, unwilling to expose themselves.

Paula R. Feldman, 'The Poet and the Profits: Felicia Hemans and the Literary Marketplace', Keats-Shelley Journal, 46 (1997), pp. 148-76. 


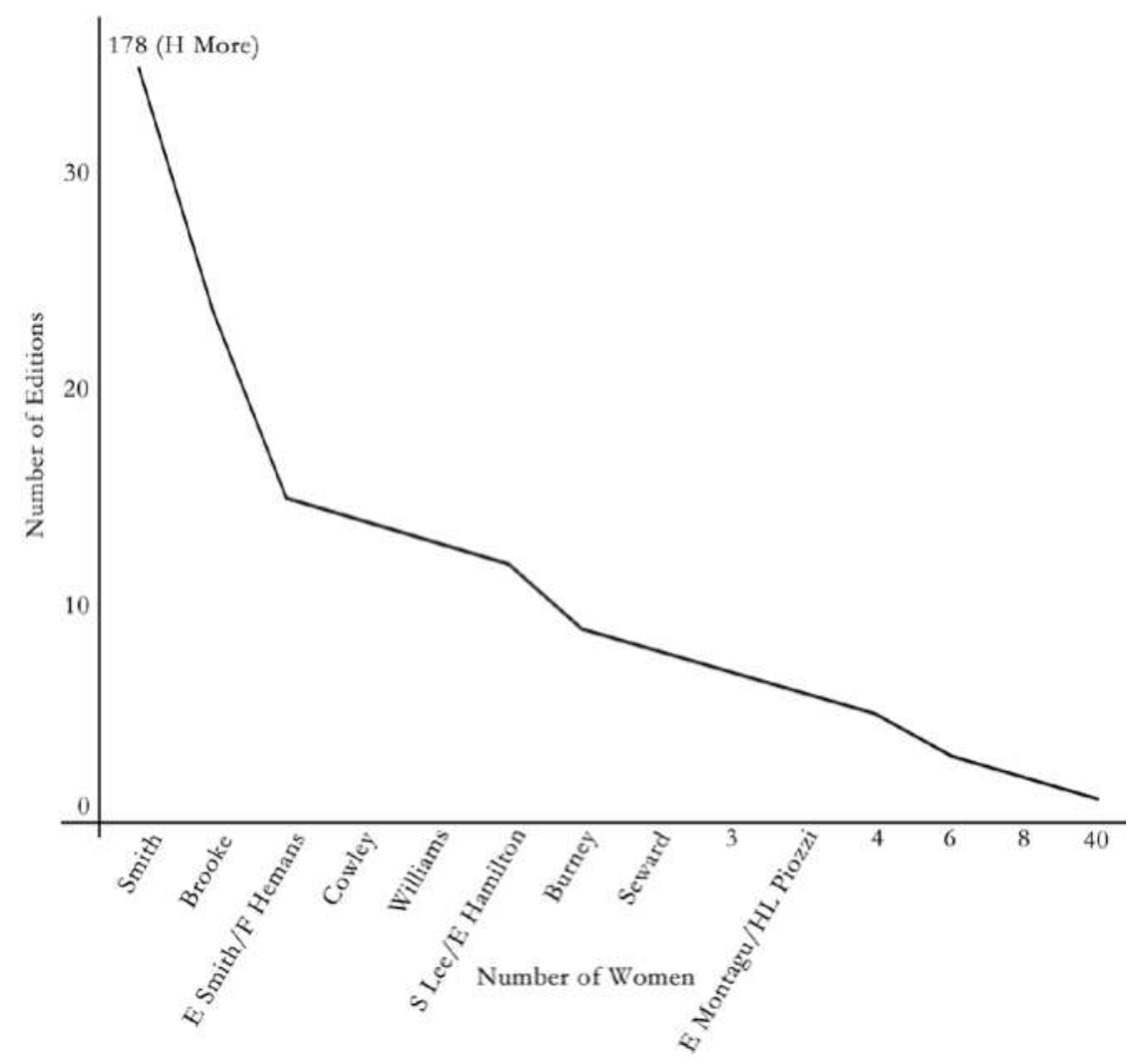

Figure 5.3: Number of editions of female authors/translators/editors, published/printed by C \& D

In our examination of the correspondence, however, we find comparatively few letters that relate directly to negotiations about publication, with the largest number of letters concerning book ordering (thirty-seven meaningful mentions), and manuscript proofing (forty meaningful mentions). As these are the most common topics in the letters, it follows that most women writing to $C \& D$ are either customers wishing to purchase books, authors or others involved in the publishing process, or a mixture of these roles. Indeed, throughout the correspondence we see overlap between the roles of the firm as publishers/booksellers, and women as authors, purchasers, and borrowers of books. Similarly, we find a blurring in the nature of the relationship between women and their publishers/ booksellers - at once personal and professional, private and public.

Recognising the imbricated nature of C \& D's engagements with women, we begin by examining how women interact with them on questions of publication in the surviving correspondence. As we can only recover agreements made with authors through correspondence (and other documents) - and with 


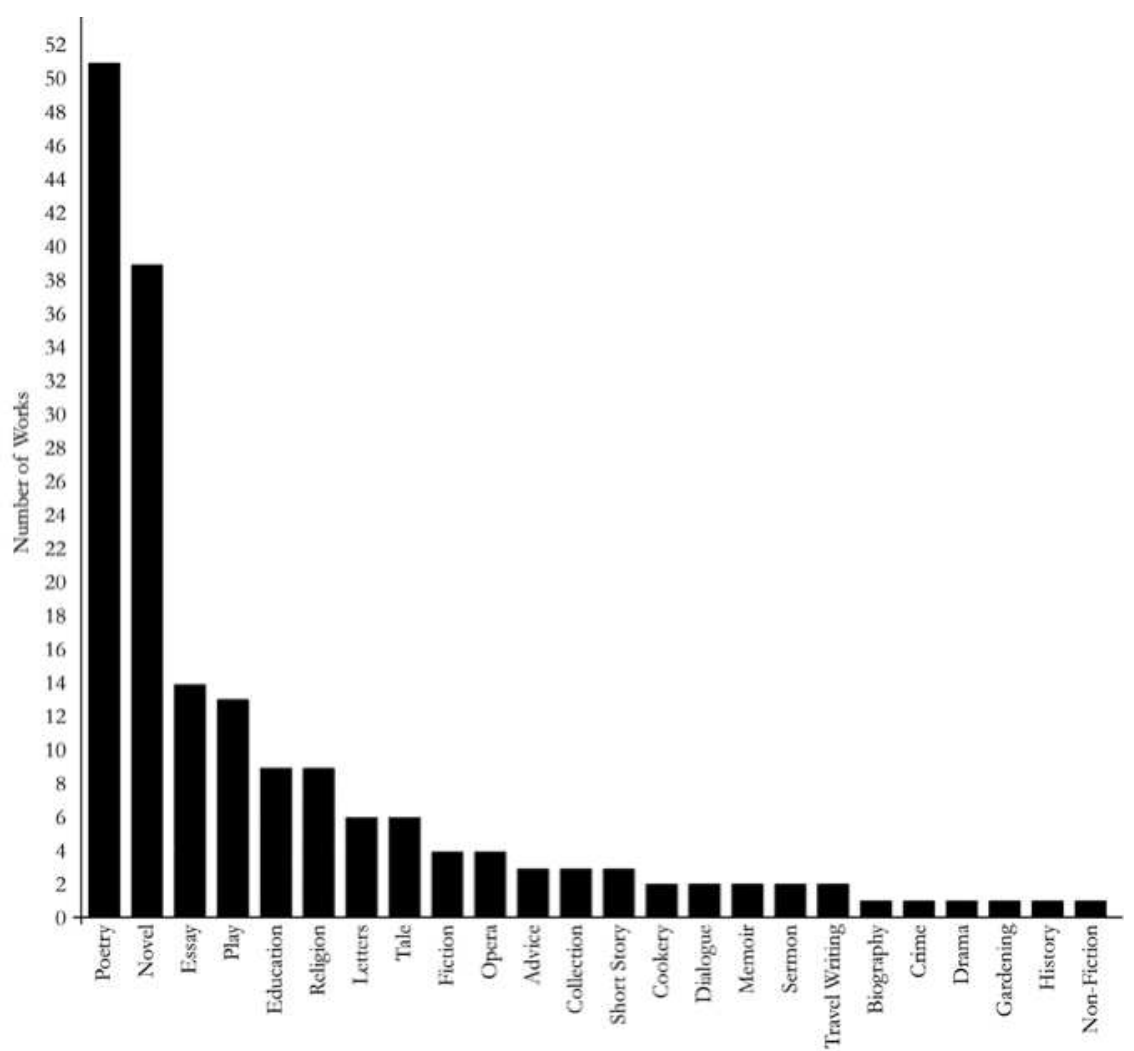

Figure 5.4: Genre breakdown of titles of works by women, published/printed by C \& D

so many women residing outside of London, it is likely that most agreements were transacted in writing - these surviving letters are the most effective means of tracking the nature of these negotiations and arrangements. We begin by addressing issues arising pre-publication, and then proceed to issues pending publication, such as proofing of copy, authorship attribution, advertising, and pricing, as well as women's involvement in the production process. The final section examines letters that address issues that arise post-publication: reviews, accounts, and payments, as well as the extensive correspondence addressing C \& D as booksellers.

Throughout our analysis, we seek to evaluate the professional and personal relationship between $\mathrm{C} \& \mathrm{D}$ and their female correspondents. Although we have portraits of other publisher-author relationships from the period, most focus on male authors. Only a few consider the relationship between publishers and women - and through a study of individual female authors at that. One of the most comprehensive studies of author-publisher relationships in the 
nineteenth century is Michael Everton's The Grand Chorus of Complaint: Authors and the Business Ethics of American Publishing. Besides presenting a series of case studies, Everton also helpfully discusses the moral discourse surrounding publishing (albeit for a later period, and across the Atlantic). Nevertheless, Everton's findings provide a useful framework for our analysis. According to Everton, authors and publishers insisted that publishing was an ethical trade, with the expectation that the publisher would act in his commercial interests, but with scrupulous fairness and decency. Everton's examples suggest how frequently publishers were thought (by both male and female authors) to have departed from these principles, often in highly public contests. ${ }^{18}$

From our survey, C \& D's conduct with women never invites this disputatiousness. As businessmen seeking profit, we find multiple examples of them implementing standards of fairness; of correspondence demonstrating unfailing politeness and responsiveness; and, in general, of gentlemanly, even chivalrous behaviour.

\section{Pre-Publication Correspondence}

Writers made solicitations then much as they do now: an author sent a manuscript with an accompanying letter describing her work, along with a brief assessment of its niche in the contemporary literary landscape. Within our corpus, six letters present works for publication; these often show women assessing the publication value of the works they describe, thereby highlighting their knowledge of the market; at other times, women ask the advice of the publisher and seek their assessment of the work. Throughout, women manifest confidence in their writing. Consider, for example, how Rose Lawrence presents her plan to arrange a miscellany of poetry: she asserts that it 'would be easy to furnish a volume of equal if not superior merit' to Riddell's Metrical Miscellany (1802), and could 'offer some very beautiful poems to the public through this medium. ${ }^{19}$ Comparing her proposed collection to Riddell's demonstrates a knowledge of C \& D's publication list, and of the contemporary market. She defers ultimate judgement to the publishers, stating that they 'will be able to judge whether works of this kind are encouraged by the public', conceding their expertise.

Solicitations often included this sort of compliment to the publisher. Women also state their preference for publication under C \& D's imprint. For instance,

\footnotetext{
${ }^{18}$ Michael Everton, The Grand Chorus of Complaint: Authors and the Business Ethics of American Publishing (Oxford: Oxford University Press, 2011).

${ }_{19}$ Letter from Rose Lawrence to C \& D, 25 October 1802, Edinburgh University Library Q. 15. 3 folio La II. 647/247, Edinburgh, United Kingdom; Maria Riddell., Metrical Miscellany (London: T. Cadell, Jun. and W. Davies, 1802).
} 
Hester Thrale Piozzi sends Thomas Cadell a letter on 7 June 1785 regarding the publication of her work Anecdotes of the Late Samuel Johnson (1786). In this letter, she explains that

As you were at once the Bookseller \& Friend of Doctor Johnson, who always spoke of your Character in the kindest Terms; I could wish you likewise to be the Publisher of some Anecdotes concerning the last twenty Years of his Life, collected by me during the many Days I had Opportunity to spend in his instructive Company; and digested into Method since I heard of his Death. ${ }^{20}$

Piozzi is savvy in her address to Cadell by appealing to both his private and commercial interests - as both 'the Bookseller \& Friend of Doctor Johnson'. Her overture was successful: Cadell published the book on 26 March 1786. ${ }^{21}$

Hannah More navigates the submission of new work with absolute confidence of its acceptance. Although the following letter is undated, the work she discusses is presumably Christian Morals (1813) - bearing close resemblance to "Christian Ethics" or something like it', the title the letter mentions. ${ }^{22}$ In the discussion, she does not question its acceptance, but directly proposes a printing schedule:

I have for some weeks been turning my thoughts to a new Work. It will be only one Volume about the size of the others. I shall probably give it the Title of 'Christian Ethics' or something like it. If health permit [sic] I think I shall be able to send a portion of it in November. will $\mathrm{M}^{\mathrm{r}}$. Strahan's Presses be at liberty at that time? I shall wish to bring it out in the Winter and therefore thought it right to apprize you of my intention. ${ }^{23}$

By 1813 More is an established author of the firm, and her assurance is warranted, having already published eighteen titles, and 110 editions, with the firm.

Publishers could also receive more unusual solicitations. On 17 December 1772, Ann Nutburn addresses Cadell 'as Bookseller of eminence in his profession, upon whose honour and secresy I may depend in any transaction'. Nutburn describes having in her possession 'a Collection of Original Letters,

${ }^{20}$ Letter from Hester Lynch Piozzi to Thomas Cadell, 7 June 1785, Houghton Library MS Hyde 69 folio 34, Cambridge, United States of America.

${ }^{21}$ Hester Lynch Piozzi, Anecdotes of the late Samuel Johnson, LL.D. during the last twenty years of his life. By Hesther Lynch Piozzi. The fourth edition. (London: T. Cadell, 1786), Eighteenth Century Collections Online. Gale. Simon Fraser University. 18 April 2016.

${ }^{22}$ Hannah More, Christian Morals (London: T. Cadell, Jun. and W. Davies, 1813).

${ }^{23}$ Letter from Hannah More to C \& D, 27 Aug, Bodleian Libraries MSS. Montagu d. 19 folio 134, Oxford, United Kingdom. 
which came into my hands in the most honourable way, written by a person of great distinction (tho I have very particular reasons against declaring the Author) upwards of 130 in Number, commencing about the year 1740 and Continued to about 1765 '. She asks $£ 200$ for the copyright, not 'an unreasonable sum', she claims, 'from the accounts I have heard of what has been given to other Authors', and also 'an additional sum to be agreed upon between us, in case the Book should go through several Editions, of which I have no doubt'. She includes copies of two letters, depending on his honour to return them, and proposes a meeting in which Cadell could peruse the rest. If he will not meet her price, she means to 'suppress them, for the present, till I can contrive a way of publishing them myself.' ${ }^{24}$ The letter is extraordinary in a few respects. It demonstrates a clandestine trade in letters (even if, as Nutburn asserts, they had been honourably obtained). It indicates that Nutburn, with apparently no ties to the trade (she has no known publication to her name, and solicits Cadell because of his reputation alone), had knowledge of its workings, as she requests a sum based on what she hears has been paid to others; she seeks profit-sharing in subsequent editions; she protects her literary property by asking for the return of the two copied letters; she names a price for the manuscript that may have been appropriate for the letters, as containing 'Anecdotes concerning most of the principal persons who figured at that time in publick life'; and she understands that the other route to publication, if copyright is not purchased outright, is self-financing. Whether a secret meeting was ever held at the Inn in Basingstoke, as Nutburn suggests, is unknown, but it appears as though Cadell never printed such a volume.

The shifting and uncertain nature of C \& D's arrangements for publication - a likely consequence of them dealing with women without extensive experience with the trade, and through correspondence - emerges in another series of letters. It was not uncommon for solicitation to go through a third party, and this could lead to protracted and/or crossing sets of messages (Levy, 'Book History', p. 312). Mr. Barratt acts as an intermediary between Lady Tuite and $\mathrm{C} \& \mathrm{D}$, as he sends them samples of her poetry. She writes to the publishers on 31 January 1796 about this work, as they have 'recommended an avowal of [her] motives for publishing', presumably in their correspondence with Mr. Barratt. ${ }^{25}$ She explains that her '[o]bject is to raise a Sum of Money as expeditiously as possible', in order to raise funds for an unnamed beneficiary. $\mathrm{C} \& \mathrm{D}$ understand that a work is more likely to prosper if this purpose is

${ }^{24}$ Letter from Ann Nutburn to Thomas Cadell, 17 December 1772, Special Collections, Cadbury Research Library, University of Birmingham CD 47, Birmingham, United Kingdom.

${ }^{25}$ Letter from Eliza Dorothea Tuite to Thomas Cadell, 31 January 1796, Bodleian Libraries MSS. Montagu d. 19, Oxford, United Kingdom. 
avowed, but Tuite resists, writing, 'this however I cannot think of; the Person I mean to serve is not in a Situation to justify an appeal to the Publick beside which I do not chuse to have it known to the family that I have any hand in the business'. ${ }^{26}$ She also indicates a wish to publish 'without giving my name', but if this will not meet with success she will 'not withold it'; although their response on this point is unknown, the volume is eventually published with her name, consistent with C \& D's position on anonymity, as we discuss below. ${ }^{27}$

The correspondence between Lady Tuite and the firm also demonstrates the range of methods of financing books available at the time. She initially states her intention to 'take the Whole on myself', that is, to self-finance the publication. With C \& D's surviving reply, we find their judicious response: 'We have taken an Opportunity of cursorily perusing the whole and think many of the Poems extremely beautiful whilst none of them appear to us calculated to bring the smallest Discredit on their Author'. C \& D make no assurances about their sales, as Lady Tuite has indicated that 'five Hundred Copies would not be Sufficient as my own Acquaintance alone'. Nevertheless, she solicits their advice as to '[w] hether it is worth my while to run the chances attendant on such an undertaking.' On the question of edition size, they diplomatically write that

With Regard to the Number to be printed, that must entirely depend upon Circumstances with which you, Madam, are alone acquainted We should, was the Work our own, not think of more in a first Edition than 500 Copies, but we recollect your mentioning that that Number would not be sufficient for your own Connections - Perhaps 750 might be the proper Number. ${ }^{28}$

In a subsequent letter from Lady Tuite, dated 8 March 1796, she once again asks for their advice: 'before you commit it to the press to peruse it $\&$ give me your Candid opinion, as to its probable success'. As she would be taking the risk upon herself, it would be important for her to know whether they thought the work might sell. As she is unable to pay the entire expense upfront, she directs them to 'deduct [the costs] from the profit'.

Typically, publishers paid the costs of paper, printing, and advertising, and would split the profit for books they felt confident would sell. It is possible they

\footnotetext{
${ }^{26}$ In a subsequent letter, 'Lady Tuite begs her Acct: may be immediately made out, as the Person for whose benefit the Book was published, is in want of the Money whatever it may be'. Letters from Eliza Dorothea Tuite to C \& D, 8 and 28 March 1796, Bodleian Libraries MSS. Montagu d. 19 folios 101-2, Oxford, United Kingdom.

27 Eliza Dorothea Tuite, Poems by Lady Tuite. (London: T. Cadell, Jun. and W. Davies, 1796), Eighteenth Century Collections Online. Gale. Simon Fraser University. 20 April 2016.

${ }^{28}$ Letter from C \& D to Eliza Dorothea Tuite, 1796, Bodleian Libraries MS Montagu d. 19 folio 101, Oxford, United Kingdom.
} 
also compensated themselves by charging a retail price on these expenses. For less optimistic books, they would ask the author to pay all expenses and charge a commission on each book. ${ }^{29}$ Authors who published in this way relied upon the expertise of publishers, as Tuite plainly does, asking for their guidance on a range of issues, from 'what number of Copies it is best to print, $\&$ as I am perfectly a Novice in matters of this kind' to 'intreat[ing them] to manage the Whole with the Reviewers, Stationers Company \&c \&c'. Tuite also dictates certain aspects of the book's production, asking for it 'to be printed to the best advantage, with respect of Type \& paper'; and suggesting a price 'as high as you think it can be with propriety I thought of half a Guinea'. Despite proceeding on the basis that she is publishing the work on her own, she also asks: 'Supposing I wished to sell the Copy right can you tell me what might be the probable Value?'

The work was published later that year, with the imprint, 'Printed for T. Cadell, Jun. and W. Davies'. The precise nature of the arrangement reached is unknown. Likely, Tuite self-financed the publication, as originally proposed, with $\mathrm{C} \& \mathrm{D}$ facilitating the printing and sale and compensating themselves either by charging commission, or charging retail prices on the paper and printing, or both. ${ }^{30}$ These letters suggest the fluidity of the author-publisher relationship, the many possible routes towards agreement, and the difficulty of reconstructing the financial arrangements reached with the imperfect surviving record.

A shrewd and successful author like Hannah More would choose to selfpublish if the price she named for copyright was not accepted. In a letter dated November 1775, likely about Sir Eldred of the Bower, and the Bleeding Rock: Two legendary tales, first published in 1776, she states her position: '... not caring to recede from my first proposals,' she requests that either C \& D purchase the copyright for forty guineas, or 'you shall print it for me and I will run the hazard of the Sale'. ${ }^{31}$ Mary Alden Hopkins provides additional context for this exchange, which led to More's first publication with the firm:

${ }^{29}$ Jan Fergus discusses publication on commission in 'The Professional Women Writer', in The Cambridge Companion to Jane Austen, ed. Edward Copeland and Juliet McMaster (Cambridge: Cambridge University Press, 1997), pp. 12-31. p. 17. Besterman confirms that $\mathrm{C} \& \mathrm{D}$ used both methods (as well as payment for copyright): pp. xxx-xxxi.

30 According to Turner, 'Self-financed publication could result also from a combination of a strong desire to get into print coupled with the money to finance it, or it might be an attempt to avoid sharing the profits with 'the Trade', a practice which was discouraged by the booksellers. Whatever the motivation, this action required a substantial investment on the part of the author, reflecting either desperation, or the author's considerable faith in the value or saleability of her work' (p. 113).

${ }^{31}$ Letter from Hannah More to Thomas Cadell, November 1775, Houghton Library, Cambridge, United States of America; Hannah More, Sir Eldred of the Bower, and the Bleeding Rock: Two legendary tales. By Miss Hannah More. (London: T. Cadell, 1776). 
Her preliminary triumph came with the publication in 1777 of two ballads. Her publisher was Thomas Cadell, London bookseller and publisher, and son of a Bristol bookseller. In his enthusiasm over his new client, he told her if she could find out how much Goldsmith had been paid for The Deserted Village she should receive the same. Goldsmith had been paid sixty guineas, but as Hannah did not know she was contented with forty pounds. The two ballads were Sir Eldred and the Bower and The Ballad of Bleeding Rock. Cadell was justified in his optimism for he and his son after him published all her best-selling books except the tracts and made a large amount of money for both author and publisher. ${ }^{32}$

Mona Scheuermann describes the preliminary exchange in a way that more closely aligns with Hannah's letter to Cadell, stating '[t]his was a woman who sent off her first poems to be published with the comment that she was not going to be put off with a piddling sum, and who was answered with the promise that if she could learn what Goldsmith had earned for "The Deserted Village," she would get a matching amount. ${ }^{33}$ Scheuermann goes on to explain that 'her proposed publisher, Cadell, apparently had not yet even seen the poems under discussion'; and that More 'could not find what Goldsmith had been paid', not that she was simply unaware '- so she and Cadell settled on $£ 40$ ' (pp. 1-2). That Cadell offered her what Goldsmith was paid (sight unseen) suggests a willingness to deal with women on the same terms as men.

After this initial exchange, Cadell and thereafter his son 'remained her publisher for more than fifty years' (Scheuermann, p. 2). Throughout we see evidence that this was a mutually beneficial relationship. Nearly forty years after her first publication appeared, an example suggests how More returned the favour, outlined by Patricia Demers: 'When Cadell's rights to her text, which she had sold, expired in 1814, More came to his rescue since "several booksellers were taking undue advantage of this, and were publishing editions of The Sacred Dramas, to his no little injury"; she wrote an additional scene ...334 As Cheryl Turner notes, 'More was unusual in her actions, which demonstrated a degree of flexibility that was possible only for a well-known author who was confident of both her entitlement to literary property, and the demand for her material' (p. 113). Certainly, More was C \& D's most important female author: her output was constant over a period of five decades, and she produced works

\footnotetext{
32 Mary Alden Hopkins, Hannah More and Her Circle (New York: Longmans, Green and Co., 1947), p. 63. In fact, the first publication of these ballads was 1776.

${ }_{33}$ Mona Scheuermann, In Praise of Poverty: Hannah More Counters Thomas Paine and the Radical Threat (Lexington: The University Press of Kentucky, 2002), p. 1.

${ }_{34}$ Patricia Demers, The World of Hannah More (Lexington: University Press of Kentucky, 1996), p. 41.
} 
that were consistently strong sellers (as is evidenced by twenty-two of her twenty-seven titles going into multiple editions, with Sacred Dramas running to over twenty editions between 1782 and 1829).

More always dealt directly with her publishers, and seems to have had their respect from the outset. But many women corresponded through intermediaries, often male, and this mediated relationship could make them vulnerable. Dr. James Currie proposes Rose Lawrence (then D'Aguilar) as a translator of Gessner, in response to C \& D's request for someone suitable for the task, ultimately published in three volumes as The Works of Solomon Gessner (1802). ${ }^{35}$ In a letter dated August 8, 1800, Currie writes:

What you mention of a translation of Gesner [sic] I have reflected upon - My young \& amiable friend is soon to be married to a very deserving young man, who having instructed her in German, is now about to give her lessons of a still more interesting nature - She will however undertake the translation of Gesner, but cannot engage as to time but will perform it with attention \& skill. I have promised to look over the sheets, \& perhaps to give a prefatory article...$^{36}$

In their reply, the firm ignores Currie's ribald comment about Rose's impending sexual initiation, and proceeds with business, requesting that Currie ask Lawrence to 'do us the Favour to mention the Remuneration that will be acceptable to her, as we have little Doubt of our immediately acceding thereto'. ${ }^{37}$ This correspondence between a gentleman and publisher, promoting a female translator, shows the web of social and literary connections that underpinned literary publication - and also the coarse way in which women's sexuality could be invoked when they were not part of the discussion.

Although they ask Lawrence to name an amount, it turns out that C \& D propose one. In the letter Lawrence sends to C \& D on 18 October 1800, she writes:

$D^{r}$. Currie has communicated to me your liberal proposal for a complete translation of Gesner's works; - \& I am perfectly satisfied with the terms

35 Salomon Gessner, The Works of Solomon Gessner, Translated from the German. With some account of his life and writings. In three volumes, trans. Rose Lawrence (London: Cadell and Davies, 1802).

${ }^{36}$ James Currie, 'Letter to C \& D, 8 Aug. 1800'. 1800. MS University of Glasgow, Centre for Robert Burns Studies, Glasgow. The Letters of James Currie (1756-1805). 17 April 2016. Web.

${ }^{37}$ C \& D, 'Letter to James Currie, 11 August 1800'. 1800. MS University of Glasgow, Centre for Robert Burns Studies, Glasgow. The Letters of James Currie (1756-1805). 17 April 2016. Web. 
you have mentioned in your last letter to him. - I cannot but be highly flattered that you think me capable of executing so difficult a task, \& I shall exert myself to the utmost to render the translation correct $\&$ spirited, $\&$ if possible to give an idea of that elegant simplicity of style which is the characteristic of Gesner's writings in their original language, tho' for the most part obscured $\&$ lost in all the translations I have yet seen of them. - I have already commenced my undertaking, \& hope to have the first volume ready for publication in January next..$^{38}$

Lawrence presents herself as a skilled and sensitive translator, capable of capturing the 'simplicity of [Gessner's] style'. She accepts the (unknown) terms they propose, but also requests, in addition to the payment, 'a dozen copies of the Work at my own disposal', an in-kind form of payment that most authors regularly requested. In addition, Lawrence expresses her concern about Thomas Stothard, the engraver the publishers have chosen; though she is 'much pleased with $\mathrm{y}^{\mathrm{r}}$ intention of ornamenting it with designs', she regrets their choice because of some of his recent compositions, and proceeds to speak with authority about other engravers whom she would prefer. C \& D reply to Lawrence, indicating that they would have thought of another artist, but Stothard is a fan of Gessner and was enthusiastic to be part of the publication. They also ask about her prefatory material for the volume, and whether she thinks a biography would be a proper part of the publication. Lawrence responds affirmatively, and prepares a lengthy, twenty-page, 'translator's preface'. These interactions demonstrate the courtesy with which C \& D dealt with Lawrence as a translator, considering her as vital as an author in shaping the volume. ${ }^{39}$

Like Hannah More, Joanna Baillie recognized the potential value of copyright, even if her publisher was unwilling to pay what she thought it was worth. In an undated letter, Joanna Baillie references a previous letter wherein she offered to sell C \& D the copyright to an unnamed work, which they declined. ${ }^{40}$ Baillie responds as follows:

I am perfectly aware that the friends of an Author are very apt to rate the value of his or her works too highly; but I assure you it was only in a commercial point of view that I considered the subject when I made you

\footnotetext{
${ }^{38}$ Letter from Rose Lawrence to C \& D, 18 October 1800[?], Edinburgh University Library Q. 15. 3 folio La II. 647/244, Edinburgh, United Kingdom.

${ }^{39}$ Letter from Rose Lawrence to C \& D, 23 December 1800[?], Edinburgh University Library Q. 15. 3 folio La II. 647/246, Edinburgh, United Kingdom.

${ }^{40}$ Joanna Baillie, A series of plays: in which it is attempted to delineate the stronger passions of the mind. Each passion being the subject of a tragedy and a comedy. By Joanna Baillie. (London: T. Cadell, Jun. and W. Davies, 1798).
} 


\section{Women's Literary Networks and Romanticism}

the proposals in question, and had not certainly the slightest wish that you should make such a bargain with me as would probably be hurtful to yourselves. When I said, (speaking of what I had asked for the copy right,) 'this is a price from which I will not recede,' I only meant that, unless I receive it, I never will give out of my own hand the property of the work, a determination which I still hold as firmly as ever, but not that I wish to receive such a sum for it, if it be more than it is worth. ${ }^{41}$

Baillie's language demonstrates the complex nature of the publisher-author relationship; on the one hand, the letter invokes the market: 'commercial', 'price', 'bargain', 'sum', 'property', 'worth'. On the other hand, a more affective discourse permeates the letter, with terms like 'wish', and 'hurtful', as Baillie expresses more of an empathic sensibility. Responding to news of the poor sales of volume two of Series of Plays, she reassures herself (and C \& D) 'that the sale of it, tho' of late it may have greatly diminished, will be of a permanent nature', and for that reason she 'must not be uneasy about it as on your account I should otherwise be', once again imagining how matters stand from her publisher's perspective.

It is notable that Baillie takes a long view regarding the value of her literary property, refusing to compromise. She expands upon her belief in the 'permanent nature' of the copyright, stating:

When I put into your hands the copy right of the 2nd vol. I believed that put in your possession that from which you would continue to derive some profit during the course even of a long life, as well as the advantages of the first sale, and you must pardon me for thinking so still. ${ }^{42}$

As with More, we find Baillie preferring to retain copyright rather than parting with it for a lesser sum (and in identical language to More, refusing to 'recede'). At the same time, she understands that it may take time for a profit to arise, and that those profits (at least to her) might be disappointing. She recollects that 'half of the profits of both first $\&$ second edition amounted only to 38 pounds'. This amount suggests that the firm may have charged retail prices for expenses, thus reducing the profit to be shared, a finding that is borne out in letters discussed subsequently. Baillie's language about the transfer of copyright ('put into your hands') also obscures the nature of that transaction. Did she donate it to them, as this suggests, or give it to them at a low price?

${ }^{41}$ Letter from Joanna Baillie to C \& D, 31 December 18[??], National Library of Scotland Acc 9026, Edinburgh, United Kingdom.

${ }^{42}$ Letter from Joanna Baillie to C \& D, 31 December 18[??], National Library of Scotland Acc 9026, Edinburgh, United Kingdom. 
Doing so would seem inconsistent with her seeking a price - too high for C \& D - for the sale of the copyright for another work, and yet the language does not imply a commercial exchange. The mixed nature of Baillie's language situates publisher-female author relations within a murky middle-ground, where the discourses of sympathy and friendship comingle with those of the trade and profit.

Several letters mention requests for the author to remain anonymous either on advertising, the title page, or both. On 14 October 1809, Margaret Holford's mother, in returning proofs of Wallace, or the Fight of Falkirk (1809), writes, 'I do not recollect receiving an answer to a request I made you in a former letter, that Miss Holford's name should not appear in the title page, or any future advertisement, and I hope I may interpret your silence into acquiescence'.43 On 15 November 1809, however, Margaret Holford writes herself, expressing disappointment that after she 'signified this desire to [C \& D] some time ago', her name had been printed in an advertisement, which she discovered through a letter from a friend in Bath. She 'repeat[s her] most particular request that if [they] have done so it may be discontinued and that [her name] may not appear in the title page' ${ }^{44} \mathrm{C} \& \mathrm{D}$ appear to respect her wishes, as the work is published anonymously.

Hannah More seeks a more nuanced form of anonymity for some of her works. In writing about a second edition of Hints Towards Forming the Character of a Young Princess (1805), she directs: 'You may also if you please add my other works to the Advertisement - but not to say "by the same Author", tho it will be understood. Nor must you print my name either in the Advertisement or the Title - tho in Conversation I now make no secret'.45 More understands the ways in which readers make author attributions, even if not explicitly stated on title pages and advertisements. In another letter, regarding a different work, she seems concerned to conceal her authorship even from close associates. She describes herself 'distressed about my friends $\mathrm{M}^{\mathrm{rs}}$. Garrick and $\mathrm{M}^{\mathrm{rs}}$. Carter because if I send them [copies] from the Author they will be sure to suspect' her authorship, and asks if Cadell could 'send them Copies without saying from the Author' ${ }^{46}$ Here, More worries that the

${ }^{43}$ Letter from Margaret Holford (Elder) to C \& D, 14 October 1809, British Library Add. MS 78687, London, United Kingdom. pp. 1-2; Holford, M., Wallace; or, The Fight of Falkirk. A metrical romance (London: T. Cadell, Jun. and W. Davies, 1809).

${ }_{44}$ Letter from Margaret Holford (Younger) to C \& D, 15 November 1809[?], British Library, Add. MS 78687, London, United Kingdom.

${ }^{45}$ Letter from Hannah More to Thomas Cadell, Jr., 5 June, Bodleian Libraries MSS. Montagu d. 19 folio 131, Oxford, United Kingdom; More, H., Hints Towards Forming the Character of a Young Princess (London, T. Cadell, Jun. and W. Davies, 1805).

${ }^{46}$ Letter from Hannah More to Thomas Cadell, British Library Add. MS 78688, London, United Kingdom. 
mere fact of a book being sent to Garrick and Carter, with the compliments of the author, from a publisher with whom she is so closely identified, would disclose her identity.

Forty letters mention manuscript proofing or corrections, making this the most prevalent descriptor. Of these, twenty - or half - are from Hannah More, demonstrating her extensive involvement in seeing her many works, and their many editions, through the press. Most of More's concerns have to do with making corrections to her works for subsequent editions: she describes, for instance 'employing [her] leisure in little improvements, tho very trifling', to Hints Towards Forming the Character of a Young Princess (1805), and 'shall be therefore obliged to know in time if there is a prospect of reaching another Edition, and my corrected Copy will be ready when called for' ${ }^{47}$ Considering that twenty-two of her twenty-seven works published by $\mathrm{C} \& \mathrm{D}$ went through more than one edition, More would have been almost constantly correcting her works in preparation for a new edition. In doing so, she sought to make 'little improvements' and thus to improve the value of each subsequent edition.

In a more unusual request, More asks $\mathrm{C} \& \mathrm{D}$, ' $[\mathrm{i}] \mathrm{f}$ the Copies are not sent already to the Reviewers, would it be too much trouble to let somebody with a Pen write in the margin' as she has 'a foolish anxiety about two unlucky errors on the $2^{\mathrm{d}}$. Vol' of Coelebs. ${ }^{48}$ Here More demonstrates a sensitivity to the reviews: for 'tho I have corrected them in the Errata, yet as that is on a leaf not likely to be turned over, those who seek for mischief, whether Scottish or English, may afford to overlook it'. A reference to Lord Byron's recently published English Bards and Scotch Reviewers, she might also have in mind the snarky review of G. W. Crowe in The London Review of the first edition in 1809, who claimed that More was 'totally ignorant' of Latin, and refused to accept the correction in the errata as evidence of an innocent mistake. ${ }^{49}$

With a less experienced author such as Lady Tuite, C \& D offer detailed instructions for proofing:

We strongly recommend your permitting us to send you a Proof of each Sheet before it is printed off, as the Printers are so apt to mistake an Author's meaning, but, if you have a Copy of the Manuscript, we need not hereafter trouble you with more than the Proof, which can be sent

${ }^{47}$ Letter from Hannah More to C \& D, 31 July 1805, British Library Add. MS 78688, London, United Kingdom.

${ }^{48}$ Letter from Hannah More to C \& D, 24 December 1809, Houghton Library MS Hyde 69, Cambridge, United States of America.

${ }^{49}$ Hannah More, Coelebs in Search of a Wife, ed. Patricia Demers (Peterborough: Broadview, 2007), p. 103, note 1. 
and returned by Post, or, if no Correction is necessary a Line informing us thereof will be sufficient $-^{50}$

By allowing Tuite to correct the proofs, C \& D were following standard practice and avoiding having to make more expensive corrections at a later point in the printing process. ${ }^{51}$ Women also comment on corrections and revisions made in the editing and proofing process, usually with satisfaction. For example, Margaret Holford the Elder returns the proofs of Wallace, thanking them for their attention to hints in the margins of the manuscript, which have all have been attended to. ${ }^{52}$

Women are also actively involved in other decisions leading up to publication, including format, number of volumes, paper, pricing, and advertising. More tells C \& D she would prefer to release her Strictures on the Modern System of Female Education (1799) in two volumes, instead of one octavo volume, though she defers to them..$^{53}$ Several women specify that they want high-quality paper. ${ }^{54}$ As we have seen, Lady Tuite asks to price her Poems at a half guinea (or ten shillings and sixpence), and Helena Wells, who published the novel Constantia Neville: or, the West Indian advises C \& D that the retail price be fifteen shillings for the three volumes. ${ }^{55}$ Women are involved in all stages of advertising, from drafting copy, to deciding where, when, and how to advertise. Issues involving advertising could, however, create confusion. Mary Anne Neri writes the only letter explicitly discussing advertising costs on 25 June 1803. In this letter, she complains that, 'as the expences of the publication \&c, have been much beyond any thing she had been led to expect, from any one who gave her information upon the subject, that they

${ }^{50}$ Letter from C \& D to Eliza Dorothea Tuite, 1796, Bodleian Libraries MSS. Montagu d. 19 folio 101, Oxford, United Kingdom.

${ }^{51}$ Philip Gaskell, A New Introduction to Bibliography: The classic manual of bibliography (Delaware: Oak Knoll Press, 1992), p. 115.

${ }_{52}$ Letter from Margaret Holford (Elder) to C \& D, 14 October 1809, British Library Add. MS 78687, London, United Kingdom.

${ }^{53}$ Letter from Hannah More to C \& D, 14 December 1798[?], Houghton Library MS Hyde 69 folio 29, Cambridge, United States of America; Hannah More, Strictures on the modern system of female education. With a view of the principles and conduct prevalent among women of rank and fortune. By Hannah More. In two volumes. (London, T. Cadell, Jun. and W. Davies, 1799).

${ }^{54}$ Letter from Maria Graham to Thomas Cadell, Jr., 7 September 1804, British Library Add. MS 78687, London, United Kingdom; letters from Miss Iremonger to C \& D, 13 June 1796 and 1796, Bodleian Libraries MSS. Eng. lett. c. 141, Oxford, United Kingdom; letter from Eliza Dorothea Tuite to C \& D, 8 March 1796, Bodleian Libraries MSS. Montagu d. 19, folio 101, Oxford, United Kingdom.

${ }_{55}$ Helena Wells, Constantia Neville; or, the West Indian. A novel. In three volumes. By Helena Wells, Author of 'the Step-Mother,' Soc. (London: T. Cadell, Jun. and W. Davies, 1800). 
will have the goodness to involve her as little as possible in further expences of advertising..$^{56}$ In situations in which copyright has not been purchased outright, authors had to bear advertising costs (which would have been deducted from profits, and could significantly diminish them).

Thus we find that $\mathrm{C} \& \mathrm{D}$ are willing to involve women in all aspects of book publication. Despite, on occasions, women complaining about failing to receive prompt replies to their letters, communication seems punctual, and proceeds without significant misunderstandings. In these relationships, C \& D appear to be unfailingly courteous, polite, and professional. Women often state that they depend on C \& D as honourable, gentlemanly, and understanding. Immediately prior to the publication of Anecdotes of the late Samuel Johnson (1786), Piozzi expresses a common sentiment, writing: 'I have the fullest Confidence of your doing every thing for our mutual Honour \& Advantage $\&$ have only to wish that the Book may be well received'. ${ }^{57}$ As we saw in Piozzi's letter to Cadell, Sr. proposing publication of the Anecdotes, and Joanna Baillie's letter to $\mathrm{C} \& \mathrm{D}$, the relationship between publisher and author is not framed as strictly commercial, but is couched in terms of mutual benefit, even friendship. In a few letters, women invite the publishers to visit, in which business and social elements intermix. Hannah Cowley says in an undated letter, 'I shall be happy if [Cadell Sr. will] do me the favour to call on me, when [he] come[s] my way' in London. ${ }^{58}$ In a letter to Cadell Jr. written from her home in Barley Wood, More asks him if he ever travels to Somersetshire, as she 'should be happy to see [him] and would give [him] a bed in one of the pleasantest rooms in England, and show [him] a fine Country', insinuating a purely social visit. ${ }^{59}$

Thirty-three letters further mention topics social or not strictly professional, including salutations to the publisher's family, discussions of being ill, or appeals to the publisher as both business contact and friend. Illness is a common discourse within the publisher/author relationship, with nine letters mentioning it; occasionally, an author's indisposition relates directly to her ability to work on writing projects. For example, Frances Brooke writes: 'my health has been so bad ever since the beginning of July[?] that I have not been able to do anything to any purpose, not even to finish my tragedy, tho' I had every reason to believe it coud $[s i c]$ have come out this

${ }^{56}$ Letter from Mary Anne Neri to C \& D, 25 June 1803, Huntington Library mssCD 1-529 box 7 folder CD 337-93, folio 360, San Marino, United States of America.

${ }^{57}$ Letter from Hester Lynch Piozzi to Thomas Cadell, 20 October 1785, Houghton Library MS Hyde 69, Cambridge, United States of America.

${ }^{58}$ Letter from Hannah Cowley to Thomas Cadell, British Library Add. MS 78686, London, United Kingdom.

${ }^{59}$ Letter from Hannah More to Thomas Cadell, Jr., 21 June, British Library Add. MS 78688, London, United Kingdom. 
year if I had' ${ }^{60}$ Hannah More explains that she is unable to deliver the other chapters, likely of Hints to a Princess (1805), and that 'the hurry of writing has affected my health'. ${ }^{61}$

The volume and nature of the casual discourse between the firm and their more prominent female authors such as Hannah More and Charlotte Smith demonstrate that these relationships were trusting and congenial. Women seek the assistance of $\mathrm{C} \& \mathrm{D}$ when they have been maligned or mistreated in some way. Hannah More, by this time with a twenty-eight year history of publishing with the firm, sends a letter on 16 March 1801 to C \& D, concerned about how one Mr. Bere 'is publishing a very False Statement, yet so specious that those who do not know his character may be taken in by it'. Published as The Blagdon Controversy: or short criticisms on the late dispute between the Curate of Blagdon [T. Bere] and Mrs Hannah More in 1801, Bere attacks More as a 'Fanatic and Enthusiast', taking out an advertisement for the book in the same paper, and on the same day, as More's works are being advertised. ${ }^{62}$ More appeals to C \& D not only as her publishers but as friends: 'I conceive it right to put my friends on their guards. You will observe the malice of advertising his Attack on the same day and in the same papers with our Eight volumes'. More trusts C \& D to defend her honour, for both personal and professional reasons.

Piozzi also appeals to the firm for assistance in clearing her name. Writing on 17 February 1786, she first mentions that Boswell 'had said some strange Thing about $\mathrm{M}^{\mathrm{rs}}$. Montagu's Essay on Shakespeare; \& laid to my Charge concerning it - Expressions $w^{\text {ch }}$ I never used'; and again on 3 March 1786 that James Boswell 'has thought fit to prejudice me in the Minds of the Publick and of $\mathrm{M}^{\mathrm{rs}}$. Montagu by giving them to understand that I disliked her [Essay on Shakespeare] to that Effect'. She asks of Cadell Sr.: 'I earnestly beg you will contradict the Report in whatever manner you think most efficacious, and assure the Town of my Esteem for the distinguished Talents of that Lady, which can only be exceeded by my Veneration of her Character. ${ }^{63}$ She also adds a postscript to the first edition of Anecdotes, disputing the charge, which in turn Boswell refutes, in a later edition of the Journal of a Tour to

${ }^{60}$ Letter from Frances Brooke to Thomas Cadell, 5 January [pre-1781], Houghton Library MS Hyde 69 folio 7, Cambridge, United States of America.

${ }^{61}$ Letter from Hannah More to C \& D, 10 December 18[04], British Library Add. MS 6048, London, United Kingdom.

${ }^{62}$ Letter from Hannah More to C \& D, 16 March 1801, Houghton Library, Cambridge, United States of America.

${ }^{63}$ Letter from Hester Lynch Piozzi to Thomas Cadell, 17 February 1786, Houghton Library MS Hyde 69, Cambridge, Unites States of America; letter from Hester Lynch Piozzi to Thomas Cadell, 3 March 1786, Houghton Library MS Hyde 69, Cambridge, United States of America. 
the Hebrides with Samuel Johnson (Piozzi, Anecdotes (1), p. 314). Finally, women could ask for other kinds of assistance. More sends a letter (undated) to C \& D recommending that John Seward work for the firm; and one Mrs. Martineau describes to Davies an apartment she has available to let, and thanks him for trying to find a single gentleman to take it. ${ }^{64}$

\section{Post-Publication Correspondence}

After publication, women were reliant on their publisher to inform them about the sales of their work, and about corrections for subsequent editions if demand warranted. Since for many women, earnings (if any) were tied to book sales, these requests for information can take on an urgent tone. Ten letters mention publication sales. One letter, from Henrietta Fordyce, enquires after the sales of her late husband James Fordyce's works; all other discussions of sales refer to works by the woman sending or receiving correspondence. A typical letter is that of Mary Anne Neri, author of The Eve of San Pietro, who would 'be particularly obliged to [C \& D] to inform her, how the sale of [the work] goes on'. ${ }^{65}$ Merely keeping track of sales could be challenging. Lady de Crespigny, in a letter to Davies on 11 July 180 [5?], asks whether an error has been made about the number of copies of her Letters of Advice from a Mother to her Son (1803): Cadell Jr. told her a few days ago that only 150 had sold, whereas Davies had told her a few months back that 250 had sold. ${ }^{66}$

Women, after receiving unfavourable reports, may offer explanations for poor or slow sales. As we have seen, Joanna Baillie acknowledges that the second volume of $A$ Series of Plays (1798) had not sold well. She suggests that perhaps the cause relates to its publication format, as a collection of a series of plays (when they were typically sold individually, in inexpensive quartos):

The lesson I ought to learn from the decrease of its late sale is, not to fatigue the public by making too many demands upon its attention.

${ }^{64}$ Letter from Hannah More to C \& D, 25 November, Bodleian Libraries MSS. Montagu d. 19 folio 130, Oxford, United Kingdom; letter from Mrs. Martineau to William Davies, 1 June 1795, Bodleian Libraries MSS. Eng. lett. Box 548 folder 43-64 folio 61, Oxford, United Kingdom.

${ }^{65}$ Letter from Mary Anne Neri to C \& D, Huntington Library mssCD 1-529 box 7 folder CD 337-93, folio 361, San Marino, United States of America; Mary Anne Neri, The Eve of San-Pietro. A Tale. In Three Volumes. (London: T. Cadell, Jun. and W. Davies, 1804), Eighteenth Century Collections Online. Gale. Simon Fraser University. 4 April 2016.

${ }^{66}$ Letter from Lady Mary Champion de Crespigny to William Davies, 11 July 18[05?], Edinburgh University Library Q. 15. 3 folio La II. 646/105, Edinburgh, United Kingdom; Lady Mary Champion de Crespigny, Letters of Advice from a Mother to her Son (London: T. Cadell, Jun. and W. Davies, 1803). 
People are accustomed to read one new play at a time and have done with it: to have a whole volume of them put into their hands at once, which they must read one after the other, because they are new and because they have been at the trouble of either buying or borrowing them, is, perhaps, rather unreasonable. ${ }^{67}$

Susannah Dobson offers an estimation of the public's reading habits to explain poor sales of a work she has translated, Jean-Baptiste de la Curne de SaintePalaye's The Literary History of the Troubadours (translation 1779). ${ }^{68}$ In a letter to Cadell (presumably Sr.; the letter is undated) asking for any money that has come from the sale, she writes: 'I imagine their antiquity $\&$ being out of the common way of Readers may make their sale what I expected would be slow and yet there is a great many remaining especially considering the situation of things at present in the world'. ${ }^{69}$

On 24 January 1786, regarding Piozzi's Anecdotes of the Late Samuel Johnson, Cadell Sr. had asked her to:

either name a price for the property or if more agreeable we will divide the profits. I mean that I shall advance for paper, print \&c. - after these are repaid to account to you for the moiety of the profits of this and future Editions. The latter mode I have followed with Mr. Gibbon, Bishop Lowth, Adam Smith, Hayley and many other of my capital Authors. I will make no Apology for troubling you on this subject as in matters of Business being explicit is the way to promote a durable connection. $^{70}$

Here we find Cadell delicately raising issues of remuneration, stating his preference for explicit arrangements both 'to promote a durable connection' and to protect her in the event that something should happen to him. Piozzi replies: 'I am perfectly satisfied to settle our pecuniary Affairs in the manner you say other people do; - dividing the profits equitably between us, when Print $\&$ Paper are paid'. ${ }^{71}$

${ }^{67}$ Letter from Joanna Baillie to C \& D, 31 December 18[??], National Library of Scotland Acc 9026, Edinburgh, United Kingdom.

${ }^{68}$ Jean-Baptiste de la Curne de Sainte-Palaye, The Literary History of the Troubadours, trans. Susannah Dobson (London: T. Cadell, 1779), Eighteenth Century Collections Online. Gale. Simon Fraser University. 12 April 2016.

${ }^{69}$ Letter from Susannah Dobson to Thomas Cadell, British Library Add. MS 78686, London, United Kingdom.

70 Thomas Cadell, 'Letter to Hester Lynch Piozzi, 24 January 1786'. 1786. MS. Electronic Enlightenment Project, Bodleian Libraries, University of Oxford. 2 May 2016. Web.

${ }^{71}$ Letter from Hester Lynch Piozzi to Thomas Cadell, 17 February 1786, Houghton 
After the rapid sale of the publication, Piozzi pertly reports to Cadell Sr. on 20 May 1786 (two months after the publication of Anecdotes) that although she 'has not heard from him about the little Books Success, [she] desires him to be assured that he is the only Friend from whom she has not heard of it; as every Post brings her very flattering Accounts of its Reception' with her friends reporting the good sales of the work. From these accounts, 'she concludes they are getting rich apace now', and directs where Cadell should send her share of the profits. ${ }^{72}$ Clearly, Piozzi assumes that she will be owed a substantial profit, likely without realising the initial outlay for printing a book was 'always alarmingly high', largely a consequence of the high cost of paper during this period (Gaskell, p. 161). Piozzi is correct that the sale was rapid; in a letter from Cadell Sr. to Piozzi dated 8 May 1786, he reports; 'the Sale [is] more rapid than any Book I ever published since my being engaged in Business. ${ }^{73}$ He proceeds to explain, however, his reason for publishing the work in smaller edition sizes, which demanded frequent re-printings:

I must own at the same time that I have consulted the reputation of the Work more than our profit for I preferred having second, third, and fourth Editions upon the Title page to printing a numerous Edition at first - If indeed I had cast off three or four thousand at once the profit would have been more considerable, but as a length of time must have elapsed before I could have advertised even a second Edition the World would have concluded that the Sale was not so extensive. I therefore printed one thousand Copies of the first Edition - these were sold off in a few hours - within the week I had a second Edition of a thousand Copies ready. The Sale of these were equally rapid - In two days I had a third Edition of 500 Copies and at the same time set about preparing for a fourth if the demand continued - the Demand did continue, and I had the fourth Edition of one thousand Copies ready for publication as soon as the third was sold off. The fourth is now selling, and I have little doubt but I shall be obliged speedily to announce a fifth edition. ${ }^{74}$

Library MS Hyde 69, Cambridge, United States of America. In a letter dated 24 January 1786, Cadell had asked Piozzi to either name her price or split the profits; Thomas Cadell, 'Letter to Hester Lynch Piozzi, 24 January 1786'. 1786. MS Electronic Enlightenment Project, Bodleian Libraries, University of Oxford. 2 May 2016. Web.

72 Letter from Hester Lynch Piozzi to Thomas Cadell, 20 May 1786, Houghton Library MS Hyde 69 folio 34, Cambridge, United States of America.

${ }^{73}$ For a fuller discussion of the printing of this work, as well as Piozzi's dispute with Boswell, see James L. Clifford, 'The printing of Mrs Piozzi's anecdotes of Dr. Johnson', The Bulletin of the John Rylands Library 20: 1 (1936), pp. 157-72.

${ }^{74}$ Hester Lynch Piozzi, 'Letter to Thomas Cadell, 20 May 1786'. 1786. MS Electronic Enlightenment Project, Bodleian Libraries, University of Oxford. 2 May 2016. Web. Note 1. 
The letter, perhaps, prepares Piozzi for the disappointing news (not disclosed in the letter) as to the profits to be shared (she is thought to have made somewhere between 130 and 300 pounds). ${ }^{75}$ Although Cadell anticipates another edition, only four editions were ultimately produced, all in 1786, and no further editions were published in her lifetime. Perhaps as a result of this somewhat disappointing profit-sharing arrangement, when Piozzi sought to sell Cadell Sr. her Observations on 14 November 1788, she demanded 500 guineas payment for the copyright, a sum that it appears Cadell did not agree to pay ${ }^{76}$

Twenty-nine letters discuss accounts, a somewhat broader category as all clients, including those that simply purchased books, might have an account with the firm. It is inevitable that these repeated requests for information about the status of an account were taxing to $\mathrm{C} \& \mathrm{D}$, given the number of authors and book buyers with whom they were dealing. Lady Tuite, for example, writes that she 'is much surprized she has had no answer from Messrs C \& D, as to her Acct: which she has repeatedly asked for'. ${ }^{77}$ Henrietta Maria Bowdler asks for her account statement in several letters, '[a]s I always am desirous to know the exact state of all my accounts, before the end of every year' ${ }^{78}$ Confusion could arise, as in a response by More to $\mathrm{C} \& \mathrm{D}$, she explains '[y]ou totally mistook in supposing I wanted my Account' when she had only wanted to know 'how many Copies of Coelebs had been printed' as people in her neighbourhood were disputing the amount, and her asking 'related simply to ascertain the number as matter of curiosity'. ${ }^{79}$ Nevertheless, from the letters reviewed, C \& D appear to have been generally punctual in sending out account statements. Within three weeks (from 11 June-1 July 1806), they send Anne Persode Blair's account with a reply to her letter, asking her to draw on them for the account due within ten days 'after Sight' of their reply. ${ }^{80}$

Authors could hold money in their accounts, rendering the publishing firm into bankers of sorts. We know that Charlotte Smith frequently asked C \& D

75 Thomas Cadell, 'Letter to Hester Lynch Piozzi, 24 January 1786'. 1786. MS Electronic Enlightenment Project, Bodleian Libraries, University of Oxford. 2 May 2016. Web. Note 6.

${ }^{76}$ Hester Lynch Piozzi, 'Letter to Samuel Lysons, 21 July 1789'. 1789. MS Electronic Enlightenment Project, Bodleian Libraries, University of Oxford. 2 May 2016. Web.

77 Letter from Eliza Dorothea Tuite to C \& D, 28 March 1797, Bodleian Libraries MSS. Montagu d. 19 folio 102, Oxford, United Kingdom.

${ }^{78}$ Letter from Henrietta Maria Bowdler to C \& D, 20 November 1806, Beinecke Rare Book and Manuscript Library MSS 510 box 1 folder 9, New Haven, United States of America.

${ }^{79}$ Letter from Hannah More to C \& D, Houghton Library, Cambridge, United States of America.

${ }^{80}$ Letter from Anne Persode Blair to C \& D [including a reply from C \& D, 1 July 1806], 11 June 1806, Bodleian Libraries MSS. Eng. lett. c. 141, Oxford, United Kingdom. 
to pay money to various creditors from her account during the years 1794 to $1797 .^{81}$ It seems clear that this was an imposition C \& D did not relish. In sending her an account statement (undated), they request she not send them any more bills, as it will cause further confusion to her account. ${ }^{82}$ Rather, as with their direction to Blair, they seem to prefer for money to be drawn from them directly.

A large proportion of letters in this collection, and the second largest category (after manuscript proofing) relate to book ordering, with mentions in thirty-seven letters. These letters demonstrate the extent to which C \& D engage with women as purchasers, reflecting the firm's combined role during the period (and that of most publishers) as publishers and booksellers. At the same time, it is important to understand the complex and multiple forms of involvement in bookselling in which C \& D were engaged.

We have seen how Rose Lawrence requested an in-kind payment, in the form of 'a dozen copies of the Work', even after an arrangement as to payment had been made; Smith and other writers would seek these forms of payment as well, thus seizing upon the publisher's dual role. As Susan Staves has found, 'Whether a particular book sent by a publisher was meant as part of the author's payment or as a gift or simply as a commodity for which the publisher expected market price was not always clear' ${ }^{83}$ In a letter dated 27 June 1798, Smith, possibly discussing The Young Philosopher (which was published in 1798) offers a typical example of her attempt to extract more from her publisher: ${ }^{84}$

But I have long since learnd that every Author but me has 20 Copies of their own work allowed them-. However as I made no bargain for that I do not now mean to press it, but as I cannot spare any I have here from my own family, I must beg the fav ${ }^{\mathrm{r}}$. of you to send two for me for which I must acct. when our account is closed. ${ }^{85}$

${ }^{81}$ Bills from Charlotte Smith to Thomas Cadell, 30 June and 16 July 1794, Beinecke Rare Book and Manuscript Library MSS 510 box 4 folder 116, New Haven, United States of America; bills from Charlotte Smith to C \& D, various [19 December 1794, 30 May 1795, 14 December 1796, 23 December 1796, 17 January 1797], Beinecke Rare Book and Manuscript Library MSS 510 box 4 folder 116, New Haven, United States of America.

${ }^{82}$ Letter from C \& D to Charlotte Smith, Beinecke Rare Book and Manuscript Library MSS 510 box 4 folder 114, New Haven, United States of America.

${ }^{83}$ Susan Staves, "Books without which I cannot write": How did Eighteenth-century Women Writers Get the Books They Read?', in Women and Material Culture, 1660-1830, ed. Jennie Batchelor and Cora Kaplan (New York: Palgrave, 2007), pp. 192-211. p. 196.

${ }^{84}$ Charlotte Smith, The young philosopher: a novel. In four volumes. By Charlotte Smith. (London: T. Cadell, Jun. and W. Davies, 1798).

${ }^{85}$ Letter from Charlotte Smith to C \& D, 27 June 1798, British Library Add. MS 78689, London, United Kingdom. 
In her analysis of Smith's correspondence with $\mathrm{C} \& \mathrm{D}$, Staves finds 'her exploiting the ambiguities of books as currency between a publisher and his author':

Smith's many letters to Cadell and Davies frequently request books. Often the requests are unaccompanied by any suggestions that she intends to pay, as she seems to have hoped the publishers would honour at least some of these requests by considering the books part of their payment to her, as support of her ongoing writing, or as gifts to one of their valued authors. Thus, she makes unadorned requests. (p. 197)

Staves cites one affecting/manipulative account, in which Smith requests copies of her books for her son, recently returned from the war as an amputee (p. 198). Hannah More, similarly and perhaps - like Smith - strategically does not seem to negotiate for copies but to request them after the fact, writing on one occasion that she 'shall be much obliged to you for a few Copies; but as beggars must not be chusers I shall leave you to fix the number. ${ }^{86}$ It should be pointed out that these reserved copies had to be sent to friends as directed by the author, another task that authors could impose on publishers.

As authors frequently published on account - books published by subscription, or by the author - publishers like C \& D were also involved in the distribution of these books. Lady Tuite, for example, asks that copies be sent to various booksellers, and complains to $\mathrm{C} \& \mathrm{D}$ when they are unavailable for purchase in some provincial bookshops. ${ }^{87}$ Hannah Cowley requests that Cadell Sr. send copies of the Belle's Stratagem to the playhouse to sell while the play is on. ${ }^{88}$

When books published by the author or by subscription did not sell, the firm might be asked to buy back the unsold books. Thus Mrs. Holford (elder) writes that her daughter thanks C \& D for 'purchasing the rest at a wholesale price. ${ }^{89}$ In a more unusual case, an author might request to purchase her books back from C \& D. In two letters between the publisher and one Miss Savage, author of the novel Massenberg, she expresses disappointment in the account information conveyed in a previous letter. She writes: 'Since the sale of this work has been so languid as to give so little hope that the remaining copies

\footnotetext{
${ }^{86}$ Letter from Hannah More to C \& D, 16 March 1801, Houghton Library, Cambridge, United States of America.

${ }^{87}$ Letter from Eliza Dorothea Tuite to C \& D, 28 March 1797, Bodleian Libraries MSS. Montagu d. 19 folio 102, Oxford, United Kingdom.

${ }^{88}$ Letter from Hannah Cowley to Thomas Cadell, British Library Add. MS 78686, London, United Kingdom; Cowley, H. The Belle's Stratagem (London: T. Cadell, 1780).

${ }^{89}$ Letter from Margaret Holford (elder) to C \& D, 14 October 1809, British Library Add. MS 78687, London, United Kingdom.
} 
may be disposed of at a profitable price, will you, Sir, permit me to send for twenty five of them to be paid for at the price at which the future copies may sell'.90 In a reply to Miss Savage, dated 14 July 1829, they offer to sell her discounted copies of her novel for five shillings in sheets, or six shillings in boards. ${ }^{91}$ We do not know the nature of the agreement between Savage and the firm, though it seems that she did not pay for the costs of printing and paper (which would entitle her to ownership of all copies). On the other hand, Savage would not be asking for her account if they had purchased the copyright (and any loss would be theirs alone). It seems likely that some sort of profit-sharing/commission arrangement was in place, and that there was no profit to be shared with her, and perhaps even a balance owing. For these reasons, C \& D assert ownership in the remaining stock, although they do offer her the wholesale price (the retail price in 1825 was twenty-one shillings). Further, in their reply they make it plain that they will not release copies until payment is received: 'they [the copies] shall be delivered to Miss Savages Order upon $\mathrm{M}^{\mathrm{r}} \mathrm{Cs}$ being favored with payment for the amount $-{ }^{.}{ }^{92}$

\section{Conclusion}

On 11 June 1806, Anne Persode Blair requested her account from C \& D. She is the widow of John Blair (d. 1782), author of The Chronology and History of the World, first published 1754. In their reply, dated 1 July 1806, they write:

We send you a Statement of your Account as desired - It is made out in the same Manner as the former Account, and therefore you will probably think our Commn. too high - If you will be so obliging as add to the 64.10-5 whatever you think right, and draw on us for the Amount thus increased at ten Days after Sight we will take Care that your Bill is duly honoured $-{ }^{93}$

Here we find C \& D responsive to the concerns of a widow of one of their authors, inviting her to add back to the account owing 'whatever you think right'. What is remarkable about this response is not merely the courtesy it

${ }^{90}$ Letter from Miss Savage to Thomas Cadell, Jr., 10 July 1829, Bodleian Libraries MSS. Eng. lett. c. 141, Oxford, United Kingdom.

${ }^{91}$ Letter from Thomas Cadell, Jr., to Miss Savage [Cecilia Mary Cadell?], 14 July 1829, Bodleian Libraries MSS. Eng. lett. c. 141, Oxford, United Kingdom; Cecilia Mary Cadell, Massenburg. A Tale. In three volumes (London: T. Cadell, Jun., 1825).

${ }^{92}$ Letter from Thomas Cadell, Jr., to Miss Savage, 14 July 1829, Bodleian Libraries MSS. Eng. lett. c. 141, Oxford, United Kingdom.

${ }_{93}$ Letter from Anne Persode Blair to C \& D [contains reply from C \& D, 1 July 1806], 11 June 1806, Bodleian Libraries MSS. Eng. lett. c. 141, Oxford, United Kingdom. 
implies, but that it is in the service of a woman whose husband had died nearly thirty years prior, and in relation to a work that had first been printed more than half a century before. In another similar situation, Margaret Riollay enquires of $\mathrm{C} \& \mathrm{D}$ in relation to the account of her late husband, Dr. Riollay. ${ }^{94}$ They advise her that he actually owed money, and propose auctioning off the remaining copies of her husband's works to pay the debt, then pay her the 'over plus', should there be any. ${ }^{95} \mathrm{C} \& \mathrm{D}$ clearly had a reputation for sensitivity and kindness, prompting these women to seek their assistance, a confidence that was not misplaced. These examples provide further evidence of the high regard in whcih women were treated by $\mathrm{C} \& \mathrm{D}$.

A final example of Cadell Sr.'s consummate professionalism may be found in his letter to Piozzi dated 24 January 1786. He writes:

I am to acknowledge the receipt of two of your Letters, and should have wrote you in answer to the one dated October 20th but my mind was then so distressed that I was wholly incapable of attending to any thing but the painful illness of a Beloved Wife. Her dissolution has deprived me of the best of Women - my Children of the most tender and affectionate of mothers. I must request your pardon for being thus particular on my own concerns. ${ }^{96}$

Reporting on the illness and death of his wife on 31 December 1785, Cadell retains his composure, but, at the same time, does not entirely suppress his grief. Indeed, Piozzi herself hardly knows how to reply, writing on 17 February 1786: 'I am much obliged to you for the letter just now sent me from Rome by Mr. Jenkins, dated 24 of January and feel sincerely mortified at the thoughts of having plagued you when your spirits were depressed by a recent misfortune'. ${ }^{\prime 7}$

Throughout the correspondence with their female authors, women manifest confidence and respect for $\mathrm{C} \& \mathrm{D}$, and the publishers are decent and compassionate to the women they trade with. In his assessment of $\mathrm{C} \& \mathrm{D}$ 's dealings with male authors, Besterman reaches a similar conclusion, although he points out several major conflicts between the firm and a handful of male authors, of which we have found no analogue in our research. Whether C \& D (and other male publishers) treated female authors differently from men - for

\footnotetext{
${ }^{94}$ Letter from Margaret Riollay to C \& D, 10 July 1799, Bodleian Libraries MSS. Montagu d. 19, Oxford, United Kingdom.

${ }^{95}$ Letter from Thomas Cadell, Jr. to Margaret Riollay, 3 August 1799, Bodleian Libraries MSS. Montagu d. 19, Oxford, United Kingdom.

96 Thomas Cadell, 'Letter to Hester Lynch Piozzi, 24 Jan. 1786'. 1786. MS Electronic Enlightenment Project, Bodleian Libraries, University of Oxford. 2 May 2016. Web.

${ }^{97}$ Letter from Hester Lynch Piozzi to Thomas Cadell, 17 February 1786, Houghton Library MS Hyde 69, Cambridge, United States of America.
} 
example, offering to pay women less for similar work - will require further comparative study. Based upon our review, however, it seems that the worst we can say of $\mathrm{C} \& \mathrm{D}$ in their dealings with women is the poor judgement they demonstrated in rejecting George Austen's submission of 'a manuscript novel, comprising 3 vols., about the length of Miss Burney's "Evelina", a novel which, if accepted, would have capped their achievement as the premier publishers of women writers of the day (Besterman, p. xxi). Instead, it was John Murray who (belatedly) recognised Jane Austen's talent, the very publisher who, according to Besterman, would eventually reach and overtake C \& D, displacing their supremacy 'at or near the head of the Trade' (p. xiv).

The literary network we have described has some important implications. A star network is often considered to be the most unequal type of network. This power imbalance occurs because the central node (C \& D) occupies a superior structural position. The central actor, because of its position in the network, possesses more opportunities than all of the other nodes: in our example, C \& D have multiple choices for whose work they publish, and this autonomy makes them less reliant on any specific other actor. Of course, all women could choose to deal with other publishers (and many discussed in this chapter did so), but nevertheless, their position within these other networks is likely to be very similar, as we know that there were far fewer publishers than writers seeking publication. In other words, this imbalance was structural within the marketplace broadly conceived. Not only does the central actor have more connections and hence more power, it also enjoys asymmetry in terms of knowledge as a result of these connections: C \& D, for example, know precisely how much they have paid (and made) through their contractual arrangements with other authors, whereas the other nodes (authors) do not share this knowledge. This structural advantage results from C \& D's centrality within the network, and suggests the relative disadvantaged position that women occupied. It is true that male authors would find themselves facing the same structural inequalities within the communications circuit, but they were not burdened with women's social, economic and cultural vulnerabilities. Our findings demonstrate that, notwithstanding their superior position, C \& D did not exploit this position. By treating their female authors with respect, C \& D reflect the high esteem in which women writers were held at the time, at least within the book trades, a position to which feminist scholars have sought, for the last half century, to restore them. 


\section{Bibliography}

\section{Primary Manuscript Sources}

Cadell and Davies, Records of Cadell and Davies, MSS CD 1-529, The Huntington Library.

Cadell and Davies Records, GEN MSS 510, General Collection, Beinecke Rare Book and Manuscript Library, Yale University.

Edinburgh University Library, Q. 15. 3.

Electronic Enlightenment Project, Bodleian Libraries, University of Oxford.

EVELYN PAPERS. Vols. DXIX-DXXII. 'Original Letters collected by William Upcott of the London Institution. Distinguished Women'; 17 th $-19^{\text {th }}$ cent. (1824), Add. MS 78686-78689, British Library.

Montagu Manuscripts, MSS. Montagu d. 19, Bodleian Libraries.

National Library of Scotland, Acc 9026.

The Cadell and Davies Papers, 1776-1887, CD 1-50, Special Collections, Cadbury Research Library, University of Birmingham.

The Donald \& Mary Hyde Collection of Dr. Johnson and Early Modern Books and Manuscripts, MS Hyde 69, Houghton Library.

Western Manuscripts at the Weston Library, Bodleian Libraries, MSS. Eng. lett. c. 141 .

\section{Print Sources}

Baillie, Joanna. A series of plays: in which it is attempted to delineate the stronger passions of the mind. Each passion being the subject of a tragedy and a comedy. London: T. Cadell, Jun. and W. Davies, 1798.

Besterman, Theodore. The Publishing Firm of Cadell and Davies: Select Correspondence and Accounts, 1793-1836. London: Oxford University, 1938.

Cadell and Davies. 'Letter to James Currie, 11 Aug. 1800'. 1800. MS, University of Glasgow, Centre for Robert Burns Studies, Glasgow. The Letters of James Currie (1756-1805). 17 April 2016. Web.

-. The following valuable books are printed for T. Cadell, Jun. and W. Davies (Successors to Mr. Cadell) in the Strand, 1796; 1797. London: Cadell and Davies, 1796; 1797. Eighteenth Century Collections Online. Gale. Simon Fraser University. 4 April 2016.

Cadell, Cecilia Mary. Massenburg. A Tale. In three volumes. London: T. Cadell, Jun., 1825.

Champion de Crespigny, Lady Mary. Letters of Advice from a Mother to her Son. London: T. Cadell, Jun. and W. Davies, 1803.

Clifford, James L. 'The printing of Mrs Piozzi's anecdotes of Dr. Johnson'. The Bulletin of the John Rylands Library, 20: 1 (1936).

Cowley, Hannah. The Belle's Stratagem. London: T. Cadell, 1780.

Currie, James. 'Letter to Cadell and Davies, 8 Aug. 1800'. MS, University of Glasgow, Centre for Robert Burns Studies. The Letters of James Currie (17561805). 17 April 2016. Web. 
de la Curne de Sainte-Palaye, Jean-Baptiste. The Literary History of the Troubadours, trans. Susannah Dobson. London: T. Cadell, 1779, Eighteenth Century Collections Online. Gale. Simon Fraser University. 12 April 2016. Web.

Demers, Patricia. The World of Hannah More. Lexington: University Press of Kentucky, 1996.

Dille, Catherine. 'Cadell, Thomas, the elder (1742-1802)', Oxford Dictionary of National Biography. Oxford: Oxford University Press, 2004, online edn., January 2008. Simon Fraser University. 10 December 2013. Web.

Eighteenth Century Collections Online, Gale. [online] Available at gale.com/ primary-sources/eighteenth-century-collections-online.

English Short Title Catalogue. [online] Available at estc.bl.uk.

Everton, Michael. The Grand Chorus of Complaint: Authors and the Business Ethics of American Publishing. Oxford: Oxford University Press, 2011.

Feldman, Paula R. 'The Poet and the Profits: Felicia Hemans and the Literary Marketplace'. Keats-Shelley Journal, 46 (1997).

Fergus, Jan. 'The Professional Women Writer', The Cambridge Companion to Jane Austen, ed. Edward Copeland and Juliet McMaster. Cambridge: Cambridge University Press, 1997.

Fergus, Jan, and Janice Farrar Thaddeus. 'Women, publishers, and money, 1790-1820', Studies in Eighteenth-Century Culture, 17 (1987).

Gaskell, Philip. A New Introduction to Bibliography: The classic manual of bibliography. Delaware: Oak Knoll Press, 1992.

Gessner, Salomon. The Works of Solomon Gessner, Translated from the German. With some account of his life and writings. In three volumes, trans. Rose Lawrence. London: Cadell and Davies, 1802.

Holford, Margaret. Wallace; or, The Fight of Falkirk. A metrical romance. London: T. Cadell, Jun. and W. Davies, 1809.

Hopkins, Mary Alden. Hannah More and Her Circle. New York: Longmans, Green and Co., 1947.

Jackson Bibliography of Romantic Poetry, 2016. [online] Available at jacksonbibliography.library.utoronto.ca.

Jackson, James Robert de Jager. Romantic poetry by women: a bibliography, 1770-1835. Oxford: Clarendon Press; New York: Oxford University Press, 1993.

Leuner, Kirstyn. 'Romantic Women Writers and The Stainforth Library: "Making Women Writers Count” (NASSR 2016)', Digital Romanticisms, n.p., 2016. Web. 27 August 2016.

Levy, Michelle. 'Do Women Have a Book History?', Studies in Romanticism, New Directions in Romanticism and Gender: Essays in Honor of Anne K. Mellor, 53: 3 (2014).

-. 'Women and Print Culture, 1780-1830', in The History of British Women's Writing, 1750-1830, ed. Cora Kaplan and Jennie Batchelor, and Jacqueline Labbe (vol. ed.), 5. Basingstoke: Palgrave Macmillan, 2010.

Looser, Devoney. 'British Women Writers, Big Data, and Big Biography, 1780-1830', Women's Writing, 22: 2 (2015). 
More, Hannah. Coelebs in Search of a Wife, ed. Patricia Demers. Peterborough: Broadview, 2007.

—. Christian Morals. London: T. Cadell, Jun. and W. Davies, 1813.

-. Hints Towards Forming the Character of a Young Princess. London, T. Cadell, Jun. and W. Davies, 1805.

-. Sir Eldred of the Bower, and the Bleeding Rock: Two legendary tales. By Miss Hannah More. London: T. Cadell, 1776.

-. Strictures on the modern system of female education. With a view of the principles and conduct prevalent among women of rank and fortune. By Hannah More. In two volumes. London, T. Cadell, Jun. and W. Davies, 1799.

Neri, Mary Anne. The Eve of San-Pietro. A Tale. In Three Volumes. London: T. Cadell, Jun. and W. Davies, 1804, Eighteenth Century Collections Online. Gale. Simon Fraser University. 4 April 2016.

Piozzi, Hester Lynch. Anecdotes of the Late Samuel Johnson, LL.D. During the last twenty years of his life. London: T. Cadell, 1786, Eighteenth Century Collections Online. Gale. Simon Fraser University. 26 April 2016.

-. Anecdotes of the late Samuel Johnson, LL.D. during the last twenty years of his life. The fourth edition. London: T. Cadell, 1786, Eighteenth Century Collections Online. Gale. Simon Fraser University. 18 April 2016.

Riddell, Maria. Metrical Miscellany. London: T. Cadell, Jun. and W. Davies, 1802. Sadleir, Michael. 'Review of The Publishing Firm of Cadell and Davies: Select Correspondence and Accounts, 1793-1836, The Library 19: 3 (1938).

Scheuermann, Mona. In Praise of Poverty: Hannah More Counters Thomas Paine and the Radical Threat. Lexington: The University Press of Kentucky, 2002.

Scragg, Brenda J. 'Lackington, James (1746-1815)', Oxford Dictionary of National Biography. Oxford: Oxford University Press, 2004, online edn., Oct 2007. Simon Fraser University. 25 April 2016.

Smith, Charlotte. The Collected Letters of Charlotte Smith, ed. Judith Phillips Stanton. Bloomington: Indiana University Press, 2003.

-. The young philosopher: a novel. In four volumes. By Charlotte Smith. London: T. Cadell, Jun. and W. Davies, 1798.

Stanton, Judith Phillips. 'Charlotte Smith’s "Literary Business": Income, Patronage, and Indigence', 1 (January 1987).

-. 'Statistical Profile of Women Writing in English from 1660-1800', in Eighteenth-Century Women and the Arts, ed. Frederick M. Keener and Susan E. Lorsch. New York: Greenwood, 1988.

Staves, Susan. "Books without which I cannot write": How did Eighteenthcentury Women Writers Get the Books They Read?', Women and Material Culture, 1660-1830, ed. Jennie Batchelor and Cora Kaplan. New York: Palgrave, 2007.

Strahan, Andrew, and Thomas Cadell. The following valuable books are printed for A. Strahan and T. Cadell, in the Strand. 1788-1793. London: A. Strahan and T. Cadell, 1788-1793, Eighteenth Century Collections Online. Gale. Simon Fraser University. 4 April 2016. 
Tuite, Eliza Dorothea. Poems by Lady Tuite. London: T. Cadell, Jun. and W. Davies, 1796, Eighteenth Century Collections Online. Gale. Simon Fraser University. 20 April 2016. Web.

Turner, Cheryl. Living by the Pen: Women writers in the eighteenth century. New York: Routledge, 1994.

Wells, Helena. Constantia Neville; or, the West Indian. A novel. In three volumes. By Helena Wells, Author of 'the Step-Mother,' \&'c. London: T. Cadell, Jun. and W. Davies, 1800.

Woolf, Virginia. A Room of One's Own. London: Penguin, 2004. 


\title{
Modelling Mary Russell Mitford's Networks
}

\author{
The Digital Mitford as Collaborative Database \\ Elisa Beshero-Bondar and Kellie Donovan-Condron ${ }^{1}$
}

In assigning to Mary Russell Mitford a place in English Literature, I am
fortunate in having the support of a critical public - of at least three
generations of readers living in the last century and a half. Did the public
verdict belong only to the author's life-time, I should, obviously, lack the
support which now, I happily possess but - and here I make a personally
bold prophecy - I believe that she will keep the place she has gained.

So begins an undated, penciled draft of a 'Lecture on Mary Russell Mitford's Place in Literature' archived at the Reading Central Library. The writer identified himself in the upper left corner of the page as 'W. J. Roberts', evidently William James Roberts, the author of an early biography of Mitford published in $1913,{ }^{3}$ but the 'century and a half' phrase suggests a much later date for the lecture, likely associating it with planned events in Mitford's home near Reading, England commemorating the centenary of Mitford's death in 1955. Reading Central Library, the public library of Reading, houses the vast majority of Mitford's papers together with documents associated with archivists and scholars who worked to organize those papers following her death, and it documents other writings from Roberts dated through the 1950s. This public library makes thousands of Mitford's papers far more readily available for viewing and photographing than we typically expect for an archive of the

1 The authors gratefully acknowledge the generous help of Gregory Bondar in crosschecking and correcting our data on Mitford's correspondents in the database he maintains for the Digital Mitford project as we prepared this chapter.

2 The draft lecture is catalogued as 'Reference stock' in the Local Studies Mitford Collection at Reading Central Library under the very general call number B/TU/MIT.

3 W. J. Roberts, Mary Russell Mitford: The tragedy of a blue stocking (London: A. Melrose, 1913). 
papers of a significant English author from a past century. ${ }^{4}$ However, Roberts' confident assertion about 'the place she has gained' seems oddly misplaced today given Mitford's general absence from, or at best minor position in, twentieth-century anthologies of nineteenth-century British literature, through which critical readers could reasonably be expected to learn about her now. His point about 'the support of a critical public' highlights an ironic distinction between critical readers within versus outside the academic institution of 'English literature' that was forming in England and North America in Roberts' day. If the importance Roberts places on 'the support of a critical public' seems so strikingly out of tune with the values shaping curricula in English in the 1950 s, it was nevertheless very much in tune with the cultivation of a reading public in the nineteenth century, a cultivation of readers that seems everywhere evident in Mitford's personal and published writings.

Mary Russell Mitford (1787-1855) had a reputation in her lifetime for writing wonderfully witty letters and prose fiction that sounded like her letters. She was successful in publishing her work like her famous contemporary Jane Austen, and in having her plays performed on the London stage like her predecessor Joanna Baillie. She was long-lived and wrote retrospectively like William Wordsworth, and she became a household name in the nineteenthcentury English-speaking world as the author of trend-setting idyllic fiction for her famous and much-beloved multi-volume series of prose sketches, Our Village. However, the 'forgetting' of Mitford in the canon-forming decisions that shaped the institution of English and its literary periods in the early twentieth century has meant that she was nearly lost from literary anthologies, so that her reputation became fragmented, and she came to remembered as a secondary support player to major authors. She would not be 'remembered' again in the way Roberts describes without the support of a critical scholarly community until after the 1980s. Now in an era of recovery and reassessment, scholarship on Mitford has been steadily increasing, so that if she does not yet have the status that Roberts assumed she had in the 1950s, she is nevertheless beginning to be recognized in diverse quarters by Romanticists and Victorianists as a path-breaking professional woman of letters - whether for her poetry and staged drama $a^{5}$ or for her prose fiction and its popularity across

${ }^{4}$ In part this is because there are no family restrictions limiting scholarly access to the papers, but also because the Reading Central librarians have permitted and encouraged our editing team to publish our own photographs of the Mitford manuscripts they hold, due to the lack of a budget for staff photography.

5 See especially Diego Saglia, 'Mediterranean Unrest: 1820s Verse Tragedies and Revolutions in the South', Romanticism 11.1 (2005): pp. 99-113 and 'When Mitford Met Baillie: Theatre, Sociability and the Networks of Women's Romantic Drama', in Women's Romantic Theatre and Drama: History, Agency, and Performativity, ed. Lilla Maria Crisafulli and Keir Elam (Farnham, England: Ashgate, 2010) pp. 123-45 among other articles by Saglia. See 
the British empire. ${ }^{6}$ Scholarship on Mitford has begun to investigate how and to what extent her romance poetry and drama anticipated work by Lord Byron on the same subjects, ${ }^{7}$ and has taken a pronounced textual turn to examine ways in which publications in periodicals and books materially altered the substance of her work. ${ }^{8}$ Her correspondence, particularly with other women, has begun to draw scholarly attention for what it reveals about women's social networks and the professionalization of women's reading and writing of literature in the nineteenth century. ${ }^{9}$ This recent scholarship on Mitford has begun to illuminate not only the writer but also much of the world of London theater production in the $1820 \mathrm{~s}$ and ' $30 \mathrm{~s}$, and it has helped to investigate the material forms that represented literary success in the book and periodical markets starting at that time, too. The fact that Mitford's voluminous correspondence survives in numbers we estimate in the two thousands makes her a compelling study for scholars interested in the exchange of ideas circulating among networks of intellectual women and men in nineteenth-century British intellectual culture.

Though her range of influence seems comparable to that of Wordsworth, Austen, Baillie, and Hemans, there is not yet a modern scholarly edition to represent Mitford's works and letters. The effort began when the Digital Mitford

also Elizabeth Raisanen, “'Speech / Is Your Fit Weapon”: Mary Russell Mitford's Rienzi and the Gendering of Speech Acts', European Romantic Review 22.2 (2011): pp. 209-33; Frederick Burwick, 'Foscari: Mitford's Dramaturgy of the Unspoken and Unexplained', in Playing to the Crowd: London Popular Theatre, 1780-1830 (New York: Palgrave Macmillan, 2011) pp. 87-100; and Elisa Beshero-Bondar, 'Mitford vs. Hemans: Resisting the "Omnipotence of Words", in Dramatic Romance and Romantic Drama'. Literature Compass 10.5 (2013): pp. 407-20.

6 See especially Deidre Lynch, 'Homes and Haunts: Austen's and Mitford's English Idylls', PMLA 115.5 (2000): pp. 1103-8; Alison Booth, 'Revisiting the Homes and Haunts of Mary Russell Mitford', Nineteenth-Century Contexts 30.1 (2008): pp. 39-65; and Josephine McDonagh. 'Rethinking Provincialism in Mid-Nineteenth-Century Fiction: Our Village to Villette', Victorian Studies 55.3 (2013): pp. 399-424.

7 Cecilia Pietropoli, 'The Tale of the Two Foscaris from the Chronicles to the Historical Drama; Mary Mitford's Foscari and Lord Byron's The Two Foscari', in British Romanticism and Italian Literature: Translating, Reviewing, Rewriting, ed. Laura Bandiera and Diego Saglia (Amsterdam: Rodopi, 2005) pp. 209-20; and Elisa Beshero-Bondar, 'Mary Russell Mitford on Lord Byron's New and Old World Territories', in Women, Epic, and Transition in British Romanticism (Newark, Delaware: University of Delaware Press, 2011) pp. 125-68.

${ }^{8}$ Kevin A. Morrison, 'Foregrounding Nationalism: Mary Russell Mitford's Our Village and the Effects of Publication Context', European Romantic Review 19.3 (2008): pp. 275-87 and 'Modulating Narrative Voice: Mary Russell Mitford's Sketches of Rural Character', Women's Writing 22.4 (2015): pp. 505-24.

9 Terence Hoagwood and Kathryn Ledbetter, 'Colour'd Shadows': Contexts in Publishing, Printing, and Reading Nineteenth-Century British Women Writers (New York: Palgrave Macmillan, 2005) pp. 76-93 and Katie Halsey, “Tell Me of Some Booklings": Mary Russell Mitford's Female Literary Networks', Women's Writing 18.1 (2011): pp. 121-36. 
project formed in 2013 to launch a scholarly archive as the most effective way to make her writings available and searchable for access to scholars and general readers, and most significantly, to make cross-referencing available to help explore the intersections among the multiple literary forms in which she wrote. These intersections will be of interest to scholars of nineteenth-century literary genres, since Mitford was successfully experimenting with prose idylls at the same time that she was negotiating to have her plays performed in London's Royal Theatres. Without the benefit of a scholarly edition encompassing her collected works, Romanticists have tended to know of Mitford mainly through the plays and early poems, while Victorianists are more often familiar with the prose writing rather than the poetry and drama. Building the archive should bridge the institutional divides that have fragmented Mitford's reputation and improve our view of the venues and conditions of nineteenth-century publication and performance.

Digital Mitford: The Mary Russell Mitford Archive announces itself as an 'archive' of Mitford's writings, but as the content of this chapter reflects, it is also a growing network of linked data, a digital database from which we can extract and study information we are collecting about people and texts of the nineteenth century. 'Archive' is surely the more conventional and expected term, suggesting comprehensive storage and preservation as well as a gateway for access to a large corpus of texts, but the term is incomplete when considering the information architecture we are developing. For much the same reason, Ed Folsom and Kenneth M. Price have each discussed the digital Walt Whitman Archive as something more complex and expansive than an 'archive', and Price deploys the term 'database' to reflect not only the informational linkages throughout their project XML files, but also the prolific linkages of names and contexts throughout Whitman's writings. ${ }^{10}$ Like many digital archives, our collective project deploys the standard XML encoding language of the Text Encoding Initiative, or TEI, to represent Mitford's writings and ultimately to build a database of them - recognizing, like the Whitman team, that our constructions are limited and qualified by human contexts and decisions, our author's as well as our own. ${ }^{11}$ Mitford appears to have shared with Whitman an inclusive tendency to incorporate

${ }^{10}$ Ed Folsom, 'Database as Genre: The Epic Transformation of Archives', PMLA 122:5 (2007): pp. 1571-9; and Kenneth M. Price, 'Edition, Project, Database, Archive, Thematic Research Collection: What's in a Name?' Digital Humanities Quarterly 3:3 (2009): pars. $18-21$.

${ }^{11}$ The TEI Consortium is a collective body representing scholars from around the world who maintain and edit its Guidelines. As specified on the TEI website, the Guidelines, first established in 1994, 'specify encoding methods for machine-readable texts, chiefly in the humanities, social sciences and linguistics' and are 'widely used by libraries, museums, publishers, and individual scholars to present texts for online research, teaching, and 
evidence of her wide reading into her writings - especially evident in her letters. That inclusive tendency makes for a richly diverse store of information on the nineteenth-century Anglophone literary world. In a likewise inclusive spirit, we hope that our most important contribution to nineteenth-century studies in the very long term will be a searchable database of heterogeneous materials, containing manuscript images and TEI markup of Mitford's more than 2,000 known letters paired with her literary texts published over a long and successful career. Through our editing of Mitford, we aim not only to provide to scholars, students, and general readers a freely accessible and helpfully annotated reading interface of her work, but also to make available hitherto unknown data about publishers of periodicals, theatre managers and actors, poets, artists, as well as politicians and educators - an extensive network bonded by mutual influence and support. Unusual intersections are coming to light from our coding of Mitford's letters, her journal, and Our Village, demonstrating, for example, that Mitford discusses Jane Austen in the same documents with Lord Byron, William Macready, Gilbert White, and Walter Scott. In light of her prolific discussion of writers, performers, and public figures, studying Mitford using 'distant reading' methods through network visualizations and graphs helps to show how her writings intersect with the familiar grounds of our knowledge - and in such visualization efforts we also expose our encoding decisions and reflect on the limits of what they can show us. ${ }^{12}$

Developing this chapter gives us an opportunity to share an inside view of the Digital Mitford as a database and reflect on the perspective we have gained in the first years of our team's work beyond what is yet visible on the project website at the time of this writing. We begin by discussing the social network that has formed around the Mitford project itself, to discuss our project's methods and priorities. We then survey what information we have gathered about Mitford's network of correspondents over the course of her life, to highlight her most frequent correspondents and mark the importance of specific mentors and friends, including her father, Sir William Elford, and Thomas Noon Talfourd, in helping to support her early publication efforts.

preservation'. See http://tei-c.org/index.xml. On the human contexts of databases, see Price, 'Edition', par. 21.

12 'Distant reading' involves applying computational processing to large corpora and investigating patterns from far away as an alternative to 'close reading', and the two methods can be used together productively: Distant reading can mark out bodies of writing outside traditional canons of literary study and suggest new areas to direct the detailed micro-level analyses of close reading. Franco Moretti introduced the term in Distant Reading, New York: Verso Books, 2013. Moretti was also one of the first to discuss Mary Russell Mitford's work in the context of Digital Humanities in Graphs, Maps, Trees: Abstract Models for a Literary History (New York: Verso, 2005), 38-42. 
We note a marked importance of a small number of male correspondents in the first half of Mitford's life, followed by a diversification of her social network as her reputation as a writer and playwright grows. Further, we observe that as Mitford's range of social contacts increases, so does her network of female correspondents, and particularly important among these are the authors Barbara Hofland and Elizabeth Barrett. Following the survey of known correspondents, we turn to the encoding work that our team has completed so far, work that spans a 'test bed' period of 1818 to 1825 , a pivotal timespan in which Mitford worked simultaneously on the sketches that would become Our Village and the plays that would establish her reputation in the London theatres. As of 30 June 2016, the corpus of TEI-encoded texts in the Digital Mitford's XML database consisted of 103 files, 75 of which were ready for querying. The 75 encoded files represent letters, prefacing material from Our Village and her plays, as well as a portion of her journal of 1819-23. We have queried our XML database of this material to extract references to people, fictional characters, and published works that are co-cited (or referenced together) in the same files in order to analyze the way Mitford associated proper names in her writings: which persons and texts were most frequently discussed.

As Price observes, databases are founded upon arguments, and the construction of systems networking information 'is not neutral, nor should it be' (par. 21). We constructed our database upon the argument that Mitford's writings help to illuminate networks of influential people and publications in the nineteenth century English-speaking world. A central matter of interest to this volume and to the Mitford project is the composition of literary women's social networks in the Romantic era, but while to a certain extent our encoding of Mitford's writings helps to illuminate a network of women, what is more strikingly evident is a network of more men than women involved in Mitford's literary life for prolonged periods. By analyzing our database of all known letters to and from Mitford, we discovered a striking pattern: the database records far more letters to men than to women, at least until the second half of Mitford's life after the successful launch of her literary career. In our editing of Mitford's writings thus far from the years 1818 to 1825, we have identified references to proper names of people, fictional characters, and publications, which gives us an opportunity to study the most frequently mentioned names and titles. Here, too, we found that Mitford wrote primarily about men and productions by men, though the ratio of her references of female to male literary characters is more roughly proportional.

In the network of Mitford's correspondents, we note the striking importance of particular male figures and that the person receiving the majority of her letters shifts over time. First, Mitford's primary correspondent is her father, to be replaced by Sir William Elford, and then Thomas Noon Talfourd, until Elizabeth Barrett becomes her most intense and prolonged 
correspondent in the 1840s, and later William Cox Bennett in the last years of her life. The evident importance of male recipients of Mitford's letters does not indicate that Mitford wrote to women rarely. Indeed, there is a wide array of female correspondents over the course of her life, but our database of archived, known, or referenced letters records comparatively fewer known letters to these correspondents. We want to emphasize that our database is necessarily incomplete, and we speculate that the archives holding the majority of Mitford's correspondence may have selected more of her letters to men for preservation, although a more extensive, as yet undocumented correspondence almost certainly exists. At this point, based on the collections we have identified, the Digital Mitford archive particularly highlights the wit and eloquence of educated female-male friendship in the nineteenth century in letters bristling with literary references. It is evident that her long-lasting friendship with Sir William Elford was especially important to Mitford to confide her ideas about prominent writers like Walter Scott, Lord Byron, and Thomas Love Peacock. Her friendship with Thomas Noon Talfourd, the same 'Serjeant Talfourd' to whom Charles Dickens dedicated Pickwick Papers for introducing a Parliament bill in 1837 to extend the term of copyright, reflects a professionally beneficial relationship beginning around $1820 .{ }^{13}$ Talfourd, who was a Reading native himself and seven years younger than Mitford, encouraged her idea to write for the London Royal Theatres to support her family after her father's financial ruin in 1820, and as William Allan Coles has documented, Talfourd was instrumental in helping Mitford to secure publishing opportunities in The Lady's Magazine and The New Monthly Magazine while he himself was publishing in these journals, and he advised her in defense of her financial interests. ${ }^{14}$ Yet her

${ }^{13}$ A stalwart champion of authors, Talfourd's friendship with and advocacy for William Wordsworth is also featured in Richard G. Swartz, 'Wordsworth, Copyright, and the Commodities of Genius', Modern Philology 89:4 (1992) pp. 482-509.

${ }_{14}$ William Allan Coles produced extremely important scholarship on Mitford's papers and periodical publications in the 1950s in his efforts to document Mitford's and Talfourd's friendship. See his 'Mary Russell Mitford: the Inauguration of a Literary Career', Bulletin of the John Rylands Library 40 (September 1957) pp. 33-46 and 'Magazine and Other Contributions by Mary Russell Mitford and Thomas Noon Talfourd', Studies in Bibliography 12 (1959) pp. 219-27. His Harvard University dissertation of 1956, The Correspondence of Mary Russell Mitford and Thomas Noon Talfourd (1821-1825) represents the first scholarly edition of a selection of Mitford's correspondence to Thomas Noon Talfourd working with papers housed at Harvard University and the John Rylands Library in Manchester. His largely unsung, meticulous scholarly efforts together with those of Francis Needham, the librarian of the Duke of Wellington in the first half of the twentieth century who left many handwritten notes in the Reading Central Library archive documenting local people and places in Mitford's world laid a strong foundation for the Digital Mitford project for which we are very grateful indeed. 
early connection with Barbara Hofland (a prolific writer of schoolbooks for children), her long-running correspondence with Emily Jephson (the grandniece of the eighteenth-century Irish dramatist Robert Jephson), and her correspondence with local and hitherto unidentified female friends, such as the Webb sisters (whose father brewed beer in Wokingham), help to document a social experience in which consuming and producing literature evidently occupied much of Mitford's daily life and mattered to her diverse array of female correspondents, including those definitely outside the pale of high society.

By the 1830s and '40s as Mitford gained popularity, newer writers sought her guidance as an experienced professional writer and editor to help them publish their work, even though her writing barely earned sufficient funds to support her aging parents and herself and she received disbursements from the Literary Fund in her late years. Should we, like W. J. Roberts, interpret her career as one of great literary success with the Anglophone reading public, or rather consider it a torment of agonizing financial distress whose tremendous effort brought only paltry rewards? ${ }^{15}$ Both assessments are apt but incomplete. In this chapter, we provide an alternative view of Mitford as a highly active writing node in a network of people and publications that shaped the literary and theatrical genres of the nineteenth century. Early twentiethcentury biographers of Mitford, Roberts as well as Vera Watson, interpreted her literary productivity as a regretful matter - as if her father failed her and betrayed her high society expectations of settled marriage and financial security through life by gambling away their mother's money ${ }^{16}-$ but the documentary record suggests a more complicated and interesting story of professionalization supported from a young age, and though pressured by economic necessity, also fueled by prodigious daily reading and writing in the self-actualization of a woman of letters. What we see of Mitford's energetic reading and writing resonates with Gilles Deleuze's and Felix Guattari's theories of networked

${ }^{15}$ For example, describing the agony of Mitford's 'success' following the acceptances of four of her plays for performances at Drury Lane and Covent Garden theatres, and the subsequent delays and quarrels with actors and theatre managers and their evasion of payments owed to her, Coles writes, 'From the letters emerges an unsurpassed picture of the theatrical conditions under which the old drama finally toppled, and they also remind us that the dark night of the soul is not restricted to the major writer alone' ('Inauguration', p. 36). From Cole's perspective, coming from Harvard in the 1950s and looking at the very start of Mitford's literary career, Mitford was not a 'major writer,' at least not yet, but her very successes seemed regularly to dash her expectations.

${ }^{16}$ Roberts describes her painstaking efforts in launching her literary career as tragically misdirected effort, 'all that a worthless father may be shielded and the real cause of the trouble be obscured' (pp. 282-3), and Vera Watson, too, blames Mitford's hard work as the fault of her father: 'He was always there to vitiate her efforts and to make her task doubly difficult', in Mary Russell Mitford (London: Evans Brothers Limited, 1949) p. 136. 
energies feeding rhizomatic social formations; more than an individual who achieved success or failure for herself, she is an energized consumer, producer, and connector who helped to generate what Roberts understood as a "critical public. ${ }^{17}$ One of the benefits of textual scholarship on Mitford may then be to help disclose the social networks of which she was a part. In the following sections, we share our visualizations of Mitford's network of correspondents as it changed over the course of her life, and we observe significant nodes of interest to whom Mitford directed the most of her writings. We then turn to the cross-section of writings that we have encoded in the project thus far, representing her writings from 1818 to '25, to analyze her references to other people and her referencing of literary and artistic titles, characters, and subjects in order to illuminate the prolific and always-connected Mary Russell Mitford at a pivotal moment within her social webs.

\section{Digital Mitford: A Collaborative Project}

A central goal of the Digital Mitford's encoding and data collection is to illuminate the networks of writers, artists, publishers, and theater professionals who contributed to Mitford's writings. Meeting that goal necessitates an interdisciplinary project team that, itself, functions as a network. In addition to the team's specialists in various aspects and genres of nineteenth-century British literature - the Romantic and Victorian eras, women writers, epic poetry, drama, novels, theory, aesthetics, transatlantic writing - Digital Mitford also draws on members' expertise in book history, bibliography, scholarly editing and data visualization, sociolinguistics, and ethnography. We are primarily professors and graduate students, and we have also involved our undergraduate students at the University of Pittsburgh, SUNY Potsdam, and UCLA in the Digital Mitford project. Our shared interests in Mitford and in digital humanities have connected us professionally as a meta-network surveying Mitford's own network.

The Digital Mitford's founding editors faced a daunting task of deciding how to organize Mitford's extensive oeuvre. Her years of writing for publication span from 1810 to 1854, from her first volume of Miscellaneous Poems to her self-collected volume of Dramatic Works published a year before her death. Throughout her life, Mitford wrote more than 2,500 letters to perhaps 175 distinct recipients, with the earliest known letter dating from 1798. Her literary work encompasses several genres, including lyric and romance poetry, staged historical tragedies, dramatic scenes and fictional sketches published in

${ }_{17}$ Gilles Deleuze and Felix Guattari, A Thousand Plateaus: Capitalism and Schizophrenia, trans. Brian Massumi (Minneapolis: University of Minnesota Press, 1987) pp. 3-25, see especially pp. 21-5 on rhizomes forming social networks. 
periodicals and annual anthologies, and the prose fiction idylls that became her best-known work, Our Village. ${ }^{18}$ Determining an appropriate cross-section for our first phase of work was the team's first collaborative decision. As the Digital Mitford team discussed where to begin, we considered but rejected a concentration on only one genre at a time. We also rejected proceeding in strict chronological order from the very earliest writings we could find. Instead, we chose to begin with the works produced in the span of years that appeared to represent the moment when Mitford began writing and producing the prose sketches and plays that established her reputation as a celebrated author. We began with a plan to encode all of Mitford's writings from between the years 1818 to 1825 that we could locate, a span that saw her remarkably intense productivity in multiple genres: her first historical tragedies performed on the London stage together with prose fiction published first in serial and then collected in the first editions of Our Village.

The challenge of accessing Mitford's texts comprised a significant element of the team's deliberation. Her letters are spread among more than three dozen collections, mostly in libraries, in England and the United States. Many of Mitford's letters remain entirely unpublished, while many more are excerpted in collections by A. G. K. L'Estrange and Henry Chorley. Perhaps her best-known literary correspondence documents her long friendship with Elizabeth Barrett, and that correspondence is searchable on The Browning's Correspondence site, though only Barrett's letters to Mitford are thoroughly represented, while Mitford's to Barrett are excerpted, with some corrections to dates, from the L'Estrange volumes. ${ }^{19}$ A. G. K. L'Estrange's late nineteenthcentury editions of Mitford's correspondence in The Life of Mary Russell Mitford: Related in a Selection of Letters From Her To Her Friends (1870) and The Friendships of Mary Russell Mitford as recorded in Letters from Her Literary Correspondents (1882) represent the only published volumes that we have of Mitford's letters that purport to be a comprehensive edition of Mitford's correspondence. These were supplemented by Henry Chorley's edition of a second series of Letters of Mary Russell Mitford in 1872, containing letters missing in the 1870 L'Estrange volumes. ${ }^{20}$ The 'L'Estrange' edition was

${ }^{18}$ First published separately in The Lady's Magazine beginning in 1819, Mitford's prose fiction sketches on rural life were collected in book form in Our Village, which ran to five editions between 1824 and 1832 with each new edition adding to the number of sketches and the number of volumes in the collection.

19 The Browning's Correspondence: An Online Edition. Wedgestone Press, 2016. browningscorrespondence.com. Accessed 23 August 2016.

20 The Life of Mary Russell Mitford, related in a selection from her letters to her friends, ed. A. G. L'Estrange, 3 vols. (London: Richard Bentley, 1870), hereafter referenced as Life. An American edition in two volumes was produced by Harper Brothers in New York in the same year. Letters of Mary Russell Mitford, second series, ed. Henry Chorley, 2 vols. (London: 
actually begun by Mitford's childhood friend and literary executor William Harness and completed by Harness's clerical understudy L'Estrange after Harness's death. Though the L'Estrange edition (which perhaps ought to be called the 'Harness edition') has long been the gateway for most scholars seeking ready access to Mitford's letters, the edition is unreliable by today's scholarly standards since it was produced to appeal to the popularity of authors' letters in the nineteenth century and further compromised by the demands of its publishers to limit the edition to three octavo volumes. ${ }^{21}$ Faced with these pressures, Harness and L'Estrange frequently condensed and compressed Mitford's correspondence, and they often spliced pieces of multiple letters together as if they were one letter. Further, Harness and L'Estrange made edits to conceal sensitive material in the letters about people then still living. Thus the transcriptions of Mitford's letters, particularly dates, are often unreliable in the L'Estrange as well as the Chorley volumes, emphasizing the need for the Digital Mitford editors to present her original letters as preserved in manuscript.

Most of Mitford's literary works, like her letters, are difficult to find in print today. While copies of Our Village remain available through used book sales, most of Mitford's work has long been out of print. Mitford's near-exclusion from contemporary anthologies of writing from this period is perhaps exacerbated by the difficulty over whether to classify Mitford as a Romantic- or Victorian-era writer, effectively obscuring the full arc of her career in literary scholarship. While Mitford herself would not have applied the post hoc labels of 'Romantic' or 'Victorian' to her writing, this periodization is common in scholarship about the nineteenth century. As Digital Mitford founding editor and bibliographer Lisa Wilson has determined, Mitford's work appears in just three anthologies of the Romantic era, the most recent of which, Women's Writing, 1778-1838: An Anthology (2001), edited by Fiona Robertson, is no longer in print. ${ }^{22}$ Jerome McGann includes one of Mitford's early poems in The

Richard Bentley and son, 1872). The Friendships of Mary Russell Mitford, as recorded in letters from her literary correspondents, ed. A. G. L'Estrange, 2 vols. (London: Hurst and Blackett, 1882), hereafter referenced as Friendships.

${ }^{21}$ For example, in a letter of 23 March 1868 to L'Estrange, Harness writes 'We must shorten the early part of Miss Mitford's life to bring it into proportion with the latter part. This can easily be done by leaving out some of the poetry, and cutting shorter her letters to Sir W. Elford; or rather abridging those epistles into letters', in A. G. L'Estrange, The Literary Life of the Rev. William Harness (London: Hurst and Blackett, 1871) p. 293. See L'Estrange's selection of Harness's letters connected with their preparing the Mitford edition, in which Harness communicates his memories of the Mitford family as well as suggestions to alter her letters: pp. 255-306.

22 Three sketches from Our Village are anthologized here: the pair 'Frost' and 'Thaw' and 'The First Primrose' in Fiona Robertson, ed., Women's Writing 1778-1838: An Anthology (Oxford: Oxford University Press, 2001) pp. 392-8. 
New Oxford Book of Romantic Period Verse (1993, $1^{\text {st }}$ edn.), ${ }^{23}$ and an additional two items - a letter dated 3 April 1815 which mentions Jane Austen, and 'Our Village', the opening story as published in the first series of Our Village (1824) - appear in Women Romantics 1785-1832: Writing in Prose (1996), edited by Jennifer Breen. ${ }^{24}$ Samantha Webb, another Digital Mitford founding editor, makes a similar observation about anthologies of Victorian literature, pointing out Mitford's absence from anthologies by the most prominent contemporary publishers, Longman, Norton, and Broadview. Webb notes that an older anthology, Prose by Victorian Women: An Anthology (1995), edited by Andrea Broomfield and Sally Mitchell, includes the 'Introduction', as well as two stories, 'Rosedale' and 'The Wood' which first appeared in magazines before being collected in Our Village. ${ }^{25}$ Mitford's longer work fares even more poorly in the modern literary marketplace. Her narrative poems, including Christina, the Maid of the South Seas (1811) (a romance poem inventing a daughter of Fletcher Christian on Pitcairn's Island) and Narrative Poems on the Female Character (1813), are too long to be excerpted effectively, while collections of Romantic-Era dramas concentrate on Mitford's more-famous contemporaries like Joanna Baillie. Thus, despite Mitford's popularity in her own time, most of her work has been unavailable for students of nineteenth-century British literature, and while her prose sketches for Our Village have been part of a long-running critical discussion regarding her role in inventing of the Victorian idyll, ${ }^{26}$ her poetry and dramas of the 1820 s have largely gone unnoticed until

${ }^{23}$ Mitford's 'Song' with first line 'The fairest things are those which live' from her first publication, Poems (1810), appears in Jerome J. McGann, ed., The New Oxford Book of Romantic Period Verse (Oxford: Oxford University Press, 1993) p. 293.

${ }^{24}$ Jennifer Breen, Women Romantics 1785-1832: Writing in Prose (London, Everyman, 1996) pp. 200-4, notes 266-7.

25 The selection of Mitford's writings, with an introduction to Mitford appears as the opening section of this anthology, still in print and available in digital form: Andrea Broomfield and Sally Mitchell, eds., Prose by Victorian Women: An Anthology (New York: Routledge, 1996) pp. 1-32. According to Samantha Webb in an e-mail message to Kellie Donovan-Condron of 3 June 2016, 'The Wood' was originally titled 'Woodcutting' in April 1823 Lady's Magazine and vastly revised for Our Village second series (1826).

${ }^{26}$ Peter David Edwards' Idyllic Realism from Mary Russell Mitford to Hardy (Basingstoke: Macmillan 1988) launched a long-running discussion of Our Village as defining the terms for idyllic fiction in the Victorian era, and later writers have addressed and responded to Edwards' claims, gradually giving Mitford increasing attention as a writer responding in complicated ways to the social issues of her region of Berkshire in the 1820s. See especially Elizabeth K. Helsinger who devotes a chapter to contrasting Our Village unfavorably with William Cobbett's Rural Rides in Rural Scenes and National Representation: Britain, 1815-1850 (Princeton University Press, 1997) pp. 103-40. More recent criticism has responded to limited contextual frames of reference in these early pieces and has tended to critique the Our Village sketches in more detail and with more specific attention to their rendering of local walkable landscapes and to their publishing history from journals 
the 1990s, when Romanticists, especially Catherine Addison and Diego Saglia, began turning serious scholarly attention to them. ${ }^{27}$

Faced with these considerations, the Digital Mitford editors selected a time period when Mitford's career was simultaneously in flux and documented in detail. At our first editors' workshop in 2013, the team's overlapping interests in the period from 1818 to 1825 guided our decision to select all of Mitford's writings from these years as our 'test bed' of texts to begin editing, on which we would create the foundation of a fully comprehensive edition of her work. Our argument has been that to best represent Mitford's diverse writings in multiple genres, we should not consider them in isolation from each other but rather in context, the better to illuminate areas of intersection previously unknown to scholarship on nineteenth-century literature. During the time covered by our test bed, Mitford had moved from poetry to drama and was building her professional network by seeking both advice on her drafts and placement for her final products. This period was also compelling because Elisa Beshero-Bondar and Gregory Bondar had previously photographed one of the largest repositories of Mitford's letters, the collection at Reading Central Library, whose librarians granted Digital Mitford permission to work from and display our photographs on our website. The combination of materials in Mitford's writings from 1818 to 1825 - dramas, prose sketches, and letters - gives us opportunities to work back and forth between Mitford's documentation of her composition, publication, and dramatic staging processes and the final versions of those texts, to produce genetic editions attentive to texts in transition and shaped by social interactions. In addition, the test bed period of 1818 to 1825 affords us opportunities to develop new scholarship on the less-often studied later years of the Romantic era, to examine how Mitford's historical tragedies developed in the same years as the sketches that came to be published as Our Village, which has until now been studied in isolation

to decorative books as a complicating factor in interpreting their politics. See Moretti, Graphs pp. 38-42, which was significant as the first treatment of Mitford's work in a digital humanities context to attempt a digital mapping of the structure of walks in Our Village. See also Lynch pp. 1103-8; Morrison, 'Foregrounding' as well as 'Modulating'; and McDonagh pp. 399-424.

${ }_{27}$ Preliminary work by Romanticists calling attention to Mitford's narrative poetry included Catherine Addison, 'Gender and Genre in Mary Russell Mitford's Christina', English Studies in Africa: A Journal of the Humanities 41.2 (1998): pp. 1-21; Diego Saglia, 'Public and Private in Women's Romantic Poetry: Spaces, Gender, Genre in Mary Russell Mitford's Blanch', Women's Writing 5.3 (1998): pp. 405-19 and 'The Spanish Princess as Domestic Heroine: Constance de Castile and Blanch of Aledo', in his Poetic Castles in Spain: British Romanticism and Figurations of Iberia (Amsterdam: Rodopi, 2000) pp. 204-25; and Elisa Beshero-Bondar, 'Romancing the Pacific Isles before Byron: Music, Sex, and Death in Mitford's Christina', ELH 76.2 (2009): pp. 277-308. For more Romanticist work on Mitford turning attention to her dramas, see footnote 5 above. 
from her dramas and poetry. Perhaps most significantly, the test bed period we selected represents a period of productivity that appears to have established Mitford's reputation both as a writer of prose fiction and as a dramatist, and our work with her letters yields new opportunities investigate how her correspondence network contributed to her rising reputation.

Digital Mitford's annual editors' workshop is the hub of our ongoing collaboration. The editors have taken on assignments covering four plays - Julian, A Tragedy in Five Acts (1823); Foscari, a Tragedy (1826); Rienzi, A Tragedy in Five Acts (1828); and the unpublished Charles I as well as early editions of Our Village and letters throughout this period. We are transcribing Mitford's letters from manuscript and hand-coding each text in the test bed to identify names, places, titles of and characters in Mitford's and other authors' works, as well as other items of interest. The workshops are held as face-to-face meetings over three to four days on the University of Pittsburgh, Greensburg campus and accessible by voice-over IP to those editors who cannot attend in person, and they provide an opportunity for editors to discuss and amend project practices, set plans, and cross-edit each other's work before it is posted in the project's XML database and transformed into HTML on the project's website at http://digitalmitford.org.

The team also discusses iterations of editorial practice at each workshop. From the outset of working with Mitford's letters, we had to decide the degree to which we would preserve her orthography. After vigorous discussion, we agreed that we are not attempting to generate exact reproductions of Mitford's physical letters, so we are not preserving, for example, her use of an equal sign when hyphenating a word at the end of a line. On the other hand, we are keeping her particular spelling choices, as well as aspects of her letters such as deletions, insertions, cross-writing, and other alterations to the words on the page, as these represent her evolving ideas and attention to precise language. In another example, our markup expanded as a result of early conversations about the letters and Our Village, which began to reveal that flowers and gardening are a substantial topic in her writing; we subsequently began work to identify botanical references in the archive. Several editors have taught or are teaching courses (notably at UCLA, University of Oregon, and SUNY Potsdam) in which undergraduate and graduate students code letters as well as some of Mitford's earlier occasional poetry, and their methodologies inform the Digital Mitford team's practice, documentation, and protocols. 


\section{Surveying Mitford's Network of Correspondents: A Distant View}

We apply network analysis methods to survey a body of material that, as noted above, is challenging to access both for its sheer volume and its transatlantic distribution. Indeed, no scholar or team has so far encompassed Mitford's entire epistolary record, though past scholars of the nineteenth and early twentieth centuries established the foundation of the project we are now building with the benefit of computational support. ${ }^{28}$ Our use of network analysis addresses this void by generating both a bird's-eye view of Mitford's entire correspondence network and narrower views of specific groups of years. Through computational methods we can detect patterns in Mitford's letterwriting hitherto outside the purview of scholarship. Our analysis pinpoints the shifts in Mitford's efforts to publish her work, as the number of letters she sends to well-connected men shifts according to their ability to help her. We also note when her network reached its greatest extent in the 1830s, when she wrote the most letters overall to the greatest number of distinct recipients. Her network subsequently contracts, with a larger number of letters going to fewer people. Correlating the waxing and waning of Mitford's letter-writing with her writing, editing, and publishing activities yields insight into the vagaries of publishing faced by women writers in these decades.

The Digital Mitford team has been tracking and recording all known archived or referenced letters to and from Mary Russell Mitford in a database designed and maintained by Gregory Bondar. The database records letters cataloged in library archives as well as any mentioned letters in other correspondence or documentation, and it holds each known letter's date and recipient, current location and provenance details, and a unique identifier for reference throughout our project. Elisa Beshero-Bondar reviewed and extracted this data for analysis in June 2016 and, together with Kellie DonovanCondron, generated the network visualizations and bar graphs that appear here to help us complete a 'distant reading' of Mitford's social network over the course of her life. We generated the bar graphs from raw counts of letters in the database, and we have presented them in five-year increments, together with a network graph for each decade of Mitford's correspondence. ${ }^{29}$ These network graphs illustrate the development and distribution of Mitford's personal and professional contacts over six decades in the first half of the nineteenth century,

\footnotetext{
28 See note 20 above.

29 We created the network graphs using Cytoscape, an open source software originally designed for biological networks of molecular interaction but adapted for network analysis in humanities and social sciences for its optimized customization of graphics and production of legible plots.
} 
and illuminate particular individuals most important to Mitford and perhaps especially helpful to her publishing and staging her work: first her father, George Mitford, then Sir William Elford, and later Thomas Noon Talfourd, who appear as three of the most prominent names in large print on the graph. We have placed special attention on what we expect to be the pivotal point of Mitford's professional career, our test bed period of 1818 to 1825 .

The network graph below (Figure 6.1) is a visualization of Mitford's entire correspondence network over her life, including anyone to whom she had written a single letter.

This graph encodes multiple layers of information. Each letter's author and recipient is a dot, or 'node'. The lines connecting nodes are called 'edges', and they represent letters shared between the nodes. The gradient of edge lines from light to dark in this visualization serves to accentuate the transitional test bed period of letters composed between 1819 and 1825. The light grey edges represent Mitford's earlier or later letters, from 1798 to 1818 and from 1826 until 1855, when she composed her last known letter, the day before her death on January 10, 1855. The dark grey edges represent our test bed period, 1819 to 1825 . While each letter creates a unique edge, we have 'bundled' the edges for clearer presentation, so that the edge lines that appear heavy or thick represent multiple letters between nodes.

This visualization is also a 'directed' graph, indicating who sent a letter to whom. The edge lines are drawn from an author node and terminate with an arrowhead pointing to the recipient node. Those nodes and their name labels are sized so that the largest are those that we have recorded in our database as having received the most letters. Mitford herself is, perhaps surprisingly, a large node here because we have recorded many letters (especially from Thomas Noon Talfourd, Elizabeth Barrett, and John Ruskin) directed to her even though our archive is primarily concentrating on letters written by her to others. In producing network diagrams from the Mitford archive, Mitford is at the center of an 'ego-network', a series of connections made primarily through her, but our database records as many letters to Mitford as we can find, so that she is not the sole sender of the letters, though as of 2016, 74 per cent of the letters in our database are written by her and 26 per cent by others. The network diagram indicates who wrote letters to Mitford and indicates correspondence between other people who mention Mitford, such as between her parents, George and Mary Mitford.

This bird's-eye view illustrates the vital link between Mitford's correspondence and her literary career. Many of her letters to her father appear early in her network, in light grey, as he functions as her literary agent and seeks opportunities for publishing her poetry. In this period, she also writes to William Elford, a long-time friend of her father's, seeking his advice and assistance in placing her work. As Mitford moves into writing dramas 


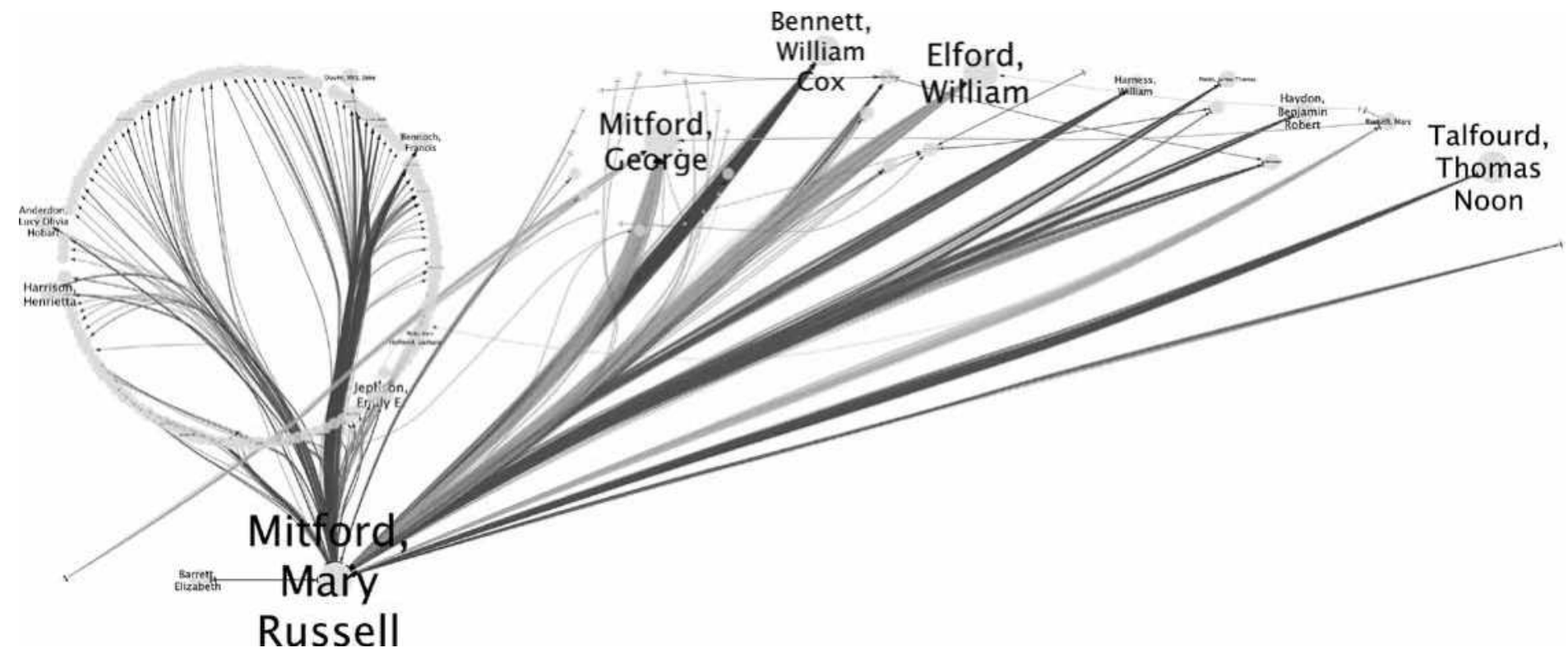

Figure 6.1: Full correspondence network, 1798-1855 
and prose, the darker grey edges increase between Mitford and Elford and decrease between father and daughter. Mitford connectes with Thomas Noon Talfourd in this period, as well. Significantly, Mitford begins or intensifies her connections with other literary women while her own career is on the rise, as the cluster of dark edges between Mitford such women as Emily Jephson and Barbara Hofland indicate. At the height of her reputation and influence, as seen in the medium grey edges, Mitford is in contact with a significant number of female authors, both well-known (Elizabeth Barrett) and relatively unknown (Henrietta Harrison). The exponential growth of Mitford's network after 1825 points to her assiduous efforts to support and promote the work a cadre of women.

As interesting as this full view of Mitford's correspondence network is, however, it illustrates only the larger patterns of the letters she wrote and received across her life. To better see how the network changed requires filtering the graph to view only the connections made in smaller units of time. To that end, we filtered the network graph to display the network as it changes decade by decade over Mitford's life, and we produced bar graphs representing the quantities of Mitford's letters directed to each recipient in intervals of five years.

Represented in Figure 6.2 and Table 6.1, Mitford's earliest letters are to and from her parents at their home in Reading while she is at school in London from 1798 to 1802 . Although the current location of these letters is unknown, Harness and L'Estrange describe them as 'entirely on domestic subjects', such as Mitford's lessons at school, her opinions about people whom she met, and gossip from home (Life, 1: pp. 14-19).

Table 6.1: Letters to Specific Recipients, 1798-1810

\begin{tabular}{lc}
\hline Distinct Recipients & Count \\
\hline Mitford, George & 48 \\
Russell, Mary & 22 \\
Elford, William & 6 \\
Mitford, Mary Russell & 4 \\
Herbert, Hon. William & 1 \\
Pratt, Samuel Jackson & 1 \\
\hline Total & 82 \\
\hline
\end{tabular}

Our record of Mitford's letters appears to stop when she returns from school (L'Estrange, Life, 1: p. 28), and her correspondence picks up again in 1806. From 1806 until 1810, when Mitford's first volume, Poems, is published, Mitford increasingly asks for her father's intervention on behalf of her own 
Modelling Mary Russell Mitford's Networks

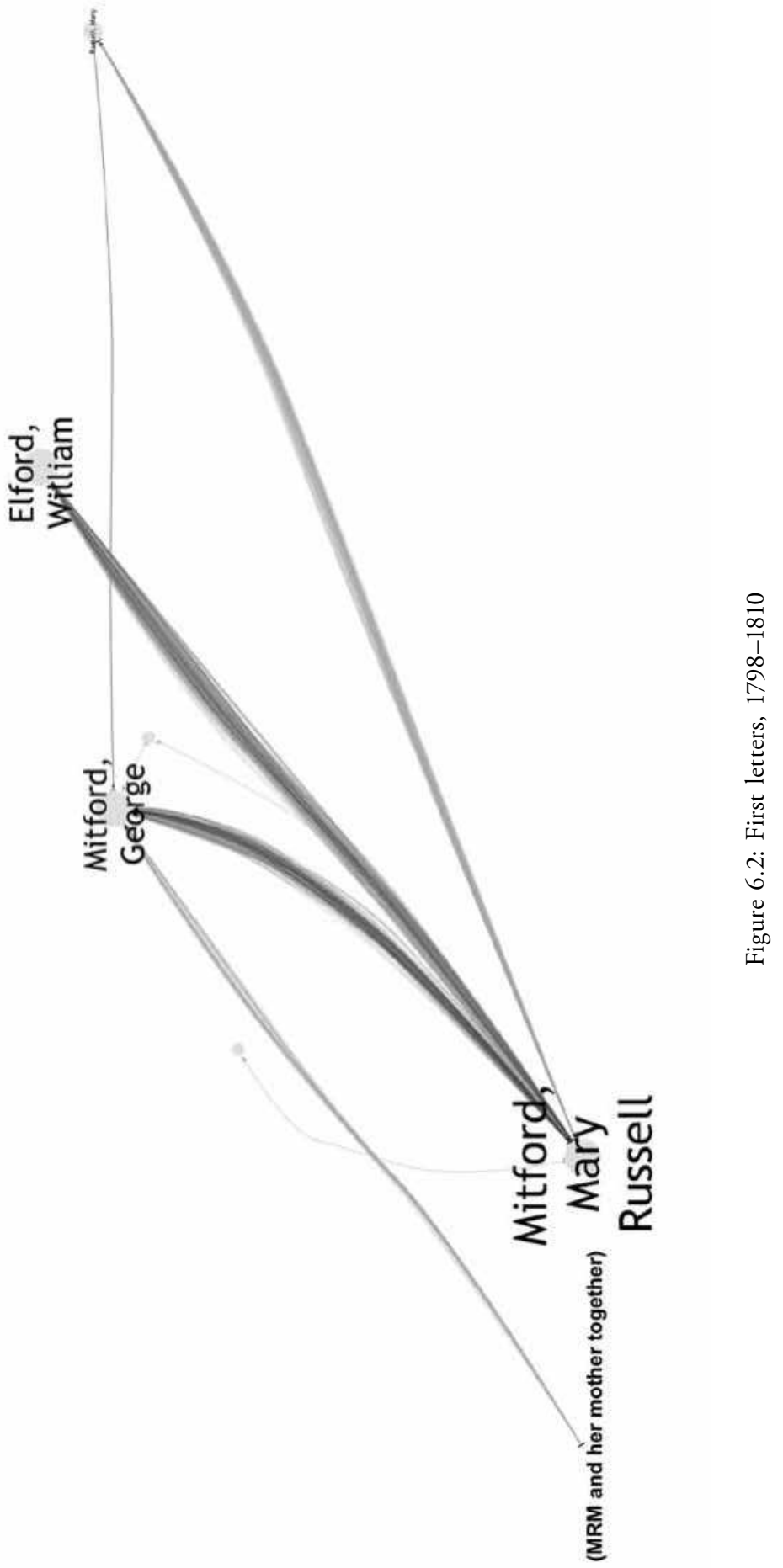


literary work and that of her friends. ${ }^{30}$ This helps to account for the significantly larger number of letters to him than to anyone else during these years. Elford's role as Mitford's some-time literary agent and long-term friend also begins in this early period.

An early letter in this period, dated May 24, 1806, contains Mitford's admiration for a politician's oratory, 'Poem on Mr. Whitbread'. Although Mitford claims that she is 'not satisfied' with the lines, she nevertheless asks her father's opinion and wants to know by return post what '[he has] done with them', implying that she hopes her father will take further action to circulate the poem despite her request that he 'return them to [her] immediately'. Similarly, in a letter to her father dated 7 June 1808, Mitford notes that his friend Sir William Elford has requested copies of her poems. Savvy enough to wish to avoid 'try[ing] his patience', Mitford directs her father to '[a]ssure [Elford] of [her] gratitude' and promises to send copies of the poems which her father had not previously shared with his friend. Mitford relies increasingly on her father as a kind of literary agent at large. L'Estrange describes a series of letters to George Mitford in February 1809, in which his daughter asks him to intervene to help the fortunes of a poem by Fanny Rowden, her school tutor, which had been poorly reviewed in the Edinburgh Review (Life, 1: pp. 68-72). While Mitford does not specify how his intervention will help Rowden's poem, she clearly believes it will. At the same time, Mitford is sending her father her own work, with directions that he 'do anything [he] like[s]' with her enclosed verses 'To the Memory of Sir John Moore', 'except sending them to the "Star"' (L'Estrange, Life, 1: 69-70). By 1810, Mitford expresses her wishes more directly, suggesting in a January letter two versions of the title for her book of poems then in production, as well as potential patrons to whom to dedicate the volume. ${ }^{31}$ Dr. Mitford continues to promote Poems after its publication, as when Mitford asks that he convey her thanks to Samuel Jackson Pratt for his 'kind approbation of [her] trifling volume'. ${ }^{32}$

George Mitford's role as Mitford's agent continues as she publishes a second, expanded edition of Poems (1811), Christina, Maid of the South Seas (1811), Watlington Hill, a Poem (1812), and British as well as American printings of Narrative Poems on the Female Character in the Various Relations of Human Life (1813) - a string of successes which doubles the number of letters Mitford writes to her father, as shown in Table 6.2.

30 The Digital Mitford database currently contains photos of letters across the arc of Mitford's life representing the Reading Central Library and the John Rylands Library collections. Our survey of the letters in this section is based on our photofacsimiles as well as excerpts from them as published in L'Estrange's Life and Henry Chorley's Letters. See L'Estrange Life 1: pp. 14-28.

${ }^{31}$ Mitford's letter to Elford of 3 January 1810 in the Reading Central Library.

${ }^{32}$ Mitford's letter to George Mitford of 4 April 1810 in the Reading Central Library. 
Table 6.2: Letters to Specific Recipients, 1811-14

\begin{tabular}{lc}
\hline Distinct Recipients & Count \\
\hline Mitford, George & 95 \\
Elford, William & 45 \\
Russell, Mary & 12 \\
Davenport, Richard Alfred & 6 \\
Taylor, John & 2 \\
Mitford, Mary Russell & 2 \\
Editor & 1 \\
\hline Total & 163 \\
\hline
\end{tabular}

George Mitford's circulation of his daughter's poems expands both her network and her writing at this time. He has shown the poem on John Moore to Richard Alfred Davenport, who then writes to Mitford directly. As she tells her father in a letter dated 22 March 1811, Davenport chides Mitford for her 'gross injustice to the Spaniards' in the poem, which in turn spurs her to 'writ[e] a poem upon a Spanish subject, though [she] may do them more injustice by [her] friendship than [her] enmity'. She pledges to write to Davenport when her epic poem Christina, then in production, is published.

However, even as George Mitford remains his daughter's most significant professional correspondent, William Elford's connection to Mitford is growing at an even faster rate, multiplying more than seven-fold since their first exchange. According to Harness and L'Estrange, Mitford had first met Elford in London in 1810 (L'Estrange, Life, 1: p. 104), and from the beginning, the two deliberately cultivated each other's friendship through letters. In her May 26, 1810 letter to Elford, Mitford asks for a sample of his poetry, while in her next, she sends him one of her poems which she had revised according to his advice and pledges to dedicate an upcoming long poem, Christina, the Maid of the South Seas, to him. Throughout 1811 to 1814, Mitford keeps Elford apprised of her progress on various compositions and discusses contemporary and past authors with him.

Although the network graph in Figure 6.3, representing 1811 to 1820, shows George Mitford and Elford as roughly equivalent in the quantities of their correspondence with Mitford, Tables 6.2 and 6.3 show what is really happening, that Elford gradually replaces George Mitford as Mitford's dominant correspondent in the second half of the decade. This is a period when Mitford's writing career slows following the publication of her early poetry.

While Mitford does not appear to be seeking Elford's advice or assistance for her own work, her letters to him continue to brim with discussion of 
Women's Literary Networks and Romanticism

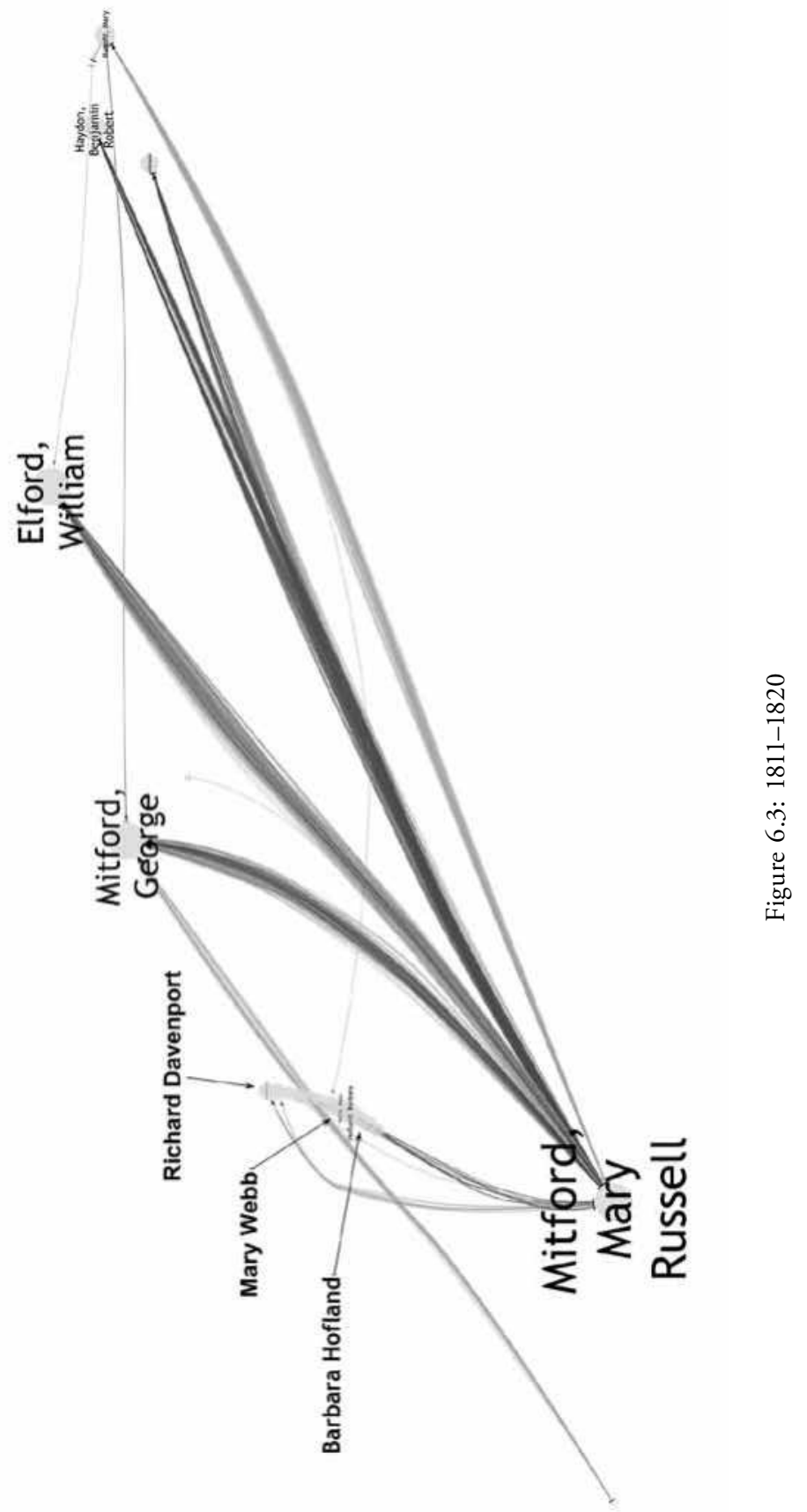


Table 6.3: Letters to Specific Recipients, 1815-20

\begin{tabular}{lclc}
\hline Distinct Recipients & Count & Distinct Recipients & Count \\
\hline Elford, William & 86 & unknown or N/A & 3 \\
Webb, Mary & 30 & Webb, Jane \& Mary & 2 \\
Hofland, Barbara & 21 & Dickinson, Mrs. & 1 \\
Haydon, Benjamin Robert & 12 & Davenport, Richard Alfred & 1 \\
Mitford, George & 10 & Haydon, Frank Scott & 1 \\
Russell, Mary & 8 & Webb, Jane & 1 \\
Powell, Mrs. & 2 & Mitford, Robert Osbaldeston & 1 \\
\hline Total & & & 179 \\
\hline
\end{tabular}

authors including Austen, Byron, Coleridge, Edgeworth, Amelia Opie, Shakespeare, Wordsworth, and Barbara Hofland, the last a mainstay of Mitford's network until her death in 1844. The Mitford-Elford friendship seems to have been stimulated by keeping up lengthy, sustained, and witty banter, and occasionally reflects on the very writing of their letters. On 25 November 1812, Elford writes, 'Pray never refrain from writing much because you want time and inclination to read over what you have written. I would a thousand times rather see what falls from your pen naturally and spontaneously (that is in a letter) than the most polished and beautiful composition that ever went to the press; and so would you, I doubt not, from your correspondents' (L'Estrange, Friendships, 1: pp. 91-2. Emphasis Elford's). For her part, Mitford appears to have confided in and laughed with Elford on paper in a way that she might not have been able to do with others. In a letter of 12 January 1818 archived at Reading Central Library and transcribed by Digital Mitford editor Amy Colombo, Mitford writes to Elford:

I have first been writing two prim letters to two prim ladies for whom I do not care three pins nor they for me - people with whom I have not an idea in common, nor an acquaintance, but who had heard as they were pleased to say that I wrote 'an exceeding good letter' - I thank them! \& availing themselves of having happened to meet me last week $\&$ having known Mama twenty years ago in Hampshire wrote to enquire after her $\&$ to request, forsooth! the pleasure of my correspondence. A great pleasure truly! If ever letters were cold-givers such are mine - Rain \& snow $\&$ fogs \& damp air all in one. - For see, my dear Sir William - that after such a job it was absolutely necessary that I should write to you - that I should supple my fingers $\&$ thaw my ideas at your warm fire $-\&$ yawn $\&$ stretch \& pity \& bemoan myself to my hearts content. You always 
let me come to you for comfort in all my troubles $\&$ this is one of the worst. Nobody can be so awkward as I am at those sort of letters - I would give the world for that comfortable amplifying style which goes on so quietly 'hoping' \& 'trusting' \& 'fearing' $\&$ 'wishing' \& proses about 'sweet infants' \& 'dear Invalids' \& 'happy convalescence' - turning \& twisting about like a hare before the dogs - with as many words as a City Orator $\&$ as few ideas as the board he bethumps. I would give the world for this sort of prosing \& mine happens to be different - I write as bad perhaps but in another way - However I will answer for it I have got quit of these correspondences I have happily ridded myself of my reputation as that $\&$ please the fates I will so demean myself as never to run the risk of having it said that I write 'an exceeding good letter' again.

We present a photofacsimile of the manuscript leaf transcribed here in Figure 6.4. The intimacy and suggestion of eroticism in this letter might well cause us to wonder about the nature of Mitford's and Elford's relationship, and apparently it did raise a question from Barbara Hofland in 1819. Elford's first wife, Mary Davies Elford, had died in 1807 and he would marry the widow Elizabeth Hall Walrond on 5 July 1821. Despite his being old enough to be Mitford's father and his having daughters about Mitford's age, it was perhaps the widowed and eligible position of Elford that caused Mitford's friend Barbara Hofland to speculate openly with her about Mitford's marriage prospects with her favorite correspondent. Mitford's reply, recorded by Chorley, presents a strong statement on the subject of marriage:

I shall not marry Sir W. Elford, for which there is a remarkably good reason, the aforementioned Sir William having no sort of desire to marry me; neither shall I ever marry anybody. I know myself well enough to be sure that if any man were silly enough to wish such a thing, and I silly enough to say 'yes', yet a timely fit of wisdom (caprice some might call it) would come upon me, and I should run away from the church door. (Letters, 1: p. 47)

If the relationship between these two seems a challenge to others to classify, it never seems to have disturbed them and their long conversational letters may also have represented a safe zone for Mitford to test her ideas, including her ideas about gender: Sir William comments in a letter of 18 June 1812:

You talk of curiosity and women being related. I won't allow more curiosity to women than to men, and you only want to establish the fact in order to display the female character. Curiosity is only another name for a thirst of knowledge. 'Tis indeed applied opprobriously 


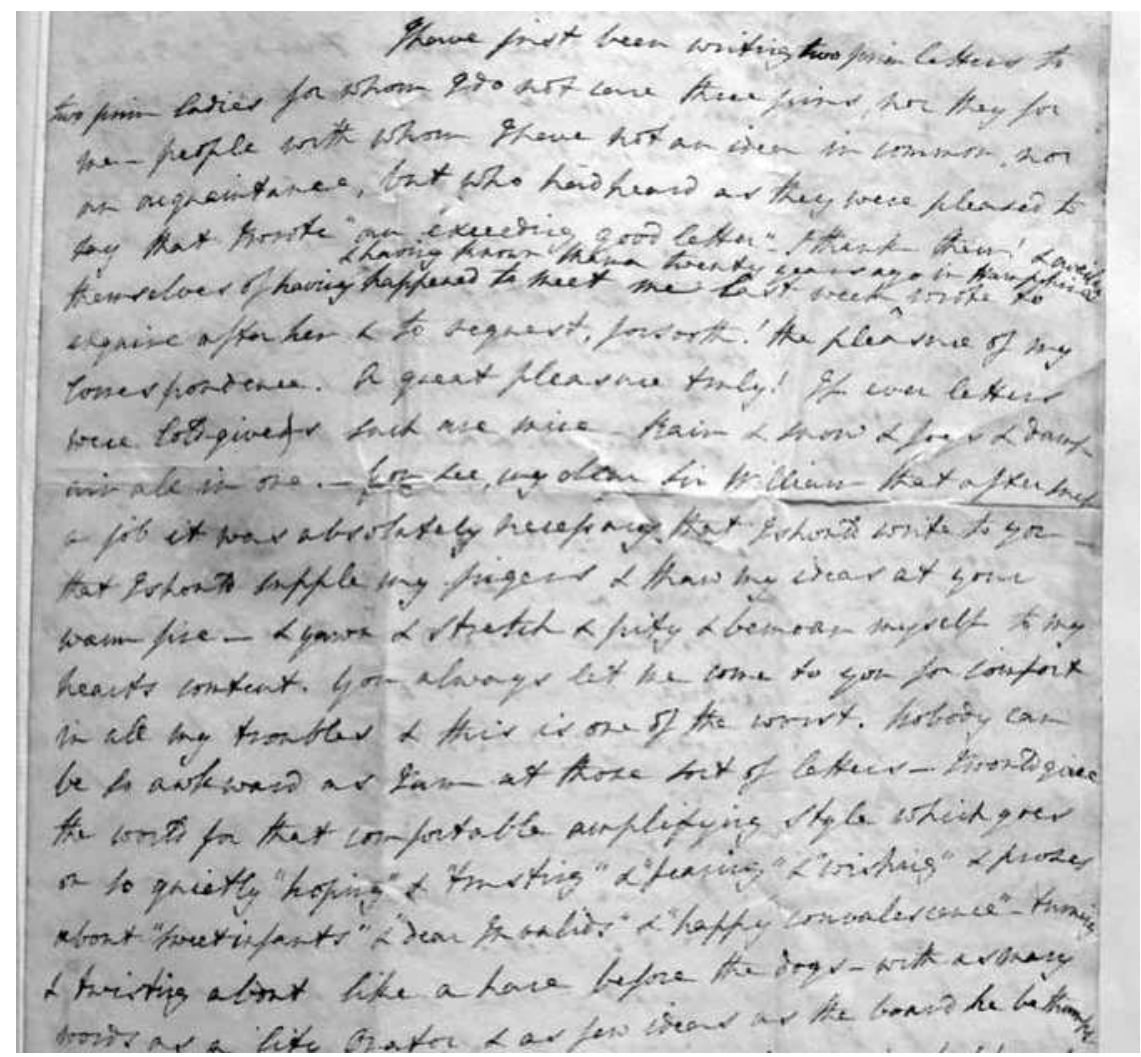

Figure 6.4: Part of the first leaf of Mitford's letter to Sir William Elford of 12 January 1818.

by wicked men when coupled with the female character, but very improperly certainly, especially as to the occasion which gave rise to your observation. (L'Estrange, Friendships, 1: p. 87)

Around this time, Mitford would have been working on her Narrative Poems of the Female Character, and Elford seems to be challenging her notions much as indeed their friendship challenges conventional views of male-female friendship in the nineteenth century.

The correspondence network expands slowly in the closing years of the decade, as Mitford begins writing to a wider circle of neighbors and acquaintances, including a deepening friendship with Hofland and a new correspondence with the painter Benjamin Robert Haydon. Mitford's first letter to Hofland, October 4, 1817, includes a sonnet written at Hofland's request (Chorley, Letters, 1: p. 27). With the addition of Hofland, Mitford's network acquires the first glimmer of the intricate support system for women writers that it would later 
become. Mitford's letters to Hofland contain deeply personal moments as she airs her literary frustrations to another woman in the profession, including details she does not share with Elford. In a letter dated 21 February 1819, Mitford tells Hofland about her 'blank verse comedy in three acts' that 'sickened [her] of writing' because her publisher, Mr. Arnold, had insisted on three rounds of revisions which led her to 'cut up [her] ten-syllable lines into songs to please him' and 'turned [her] comedy into an opera'. Mitford declares that she 'gave it up in a quiet sulky sort of passion, and [has] never written a line for publication since' (Chorley, Letters, 1: p. 44). In contrast, Mitford's letters to Haydon are formal for quite some time, addressing him as 'My Dear Sir', on 12 January and 13 February 1819 (L'Estrange, Life, 2: pp. 51, 53). Although a year later, on 1 May 1820, they are close enough for Haydon to give Mitford one of his studies, her thank you note continues to call him 'sir'. ${ }^{33}$ It is not until the fall of that year that Mitford softens her address to 'My Dear Mr. Haydon', and speaks warmly of his straightened circumstances due to the vagaries of his 'cold, proud, selfish, "patrons"' (L'Estrange, Life, 2: p. 108). While many of Mitford's letters are quite similar - for example, those to Elford and Hofland discuss art and literary works as well as local happenings and Mitford's travels to London - her letters to Haydon are an important reminder that Mitford's multi-faceted network includes both intimates and mere acquaintances, and relationships that blend the personal and the professional.

The 1820s, comprising most of the Digital Mitford test bed, see a significant expansion of Mitford's network as illustrated in Figure 6.5 and Tables 6.4 and 6.5. By comparison with the 179 letters she wrote to 14 individuals between 1815 and 1819, Mitford wrote 257 letters to 19 people between 1821 and 1825, and 150 to 34 people between 1826 and 1830. The numbers reflect a shift in Mitford's correspondence: she seems to have written more letters per person before 1825 than after that point, when her correspondents increase significantly as her professional network expands.

In the early 1820s, Mitford increases her correspondence while working on the tragedies Foscari, Rienzi, Charles I, and the stories of Our Village. As much as she depends on Thomas Noon Talfourd, writing to him at least once per month and typically two or three times per month throughout the turbulent composition and revision period of Foscari, she also comes to depend on others, including Hofland, Emily Jephson, and William Harness, asking for each of their suggestions for new writing projects in various genres. On 19 April 1821, Mitford asks Hofland if she or her husband could 'furnish [Mitford], from history, or fiction, or imagination, with a high, ample, magnificent plot, something middle-aged and Italian', and on 8 June, she thanks Hofland for 'giving [her] the aid of that which is most precious - thought and time'

${ }^{33}$ L'Estrange identifies the subject as Haydon's study for the head of St. Peter, Life 2:95. 
Modelling Mary Russell Mitford's Networks

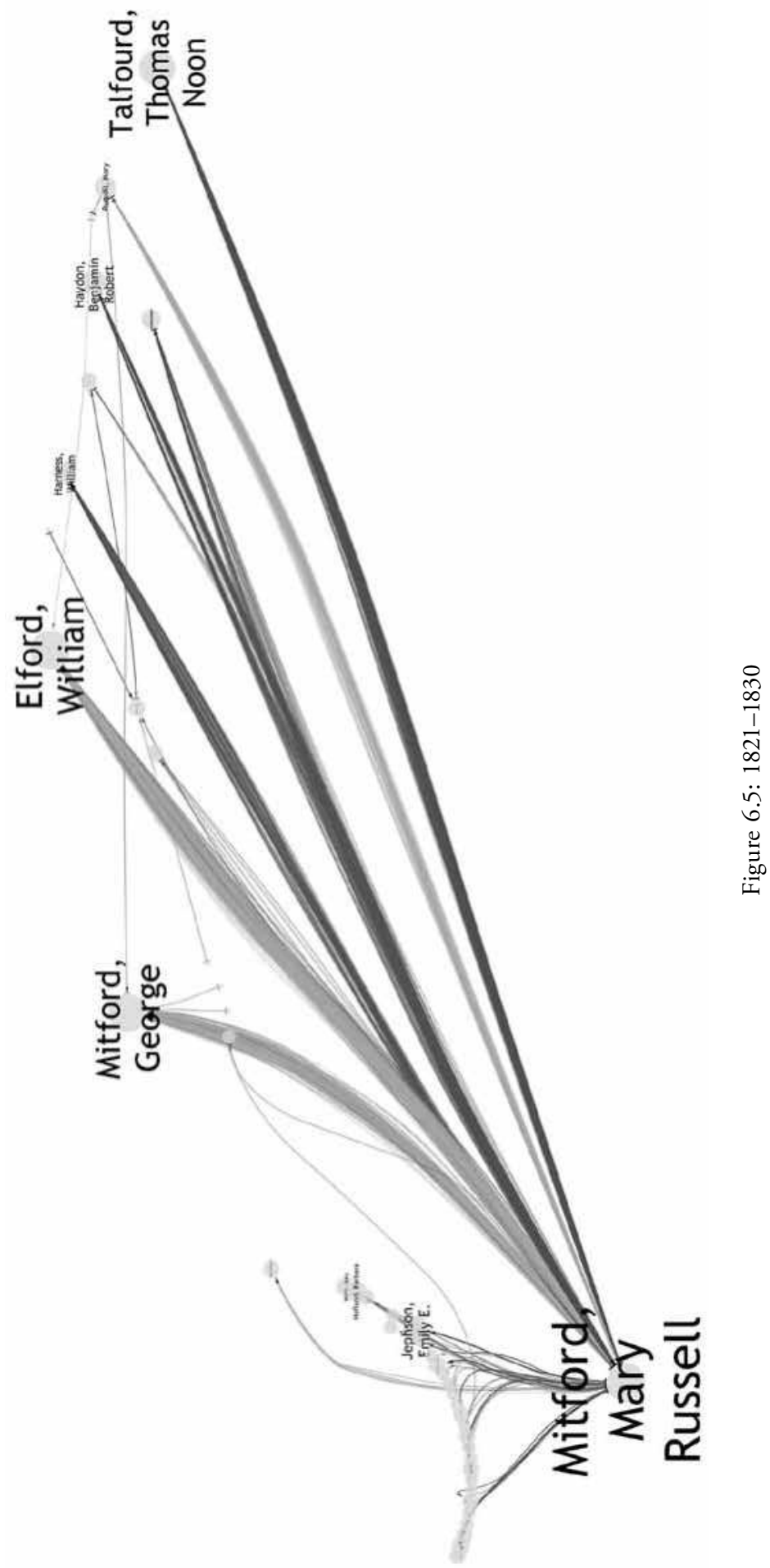


Table 6.4: Letters to Specific Recipients, 1821-25

\begin{tabular}{lrlc}
\hline Distinct Recipients & Count & Distinct Recipients & Count \\
\hline Talfourd, Thomas Noon & 104 & unknown & 3 \\
Haydon, Benjamin Robert & 50 & Mitford, George & 3 \\
Elford, William & 32 & Kemble, Charles & 2 \\
Mitford, Mary Russell & 13 & Benyon, Richard & 1 \\
Hofland, Barbara & 12 & Stovin, Mrs. M. & 1 \\
Harness, William & 9 & Valpy, Abraham F. & 1 \\
Jephson, Emily E. & 7 & Hamilton, S. & 1 \\
Colman, George, Jr. & 6 & Stephenson, Miss & 1 \\
Wrangham, Francis & 6 & Webb, Mary & 1 \\
Macready, William C. & 4 & & 257 \\
\hline Total & & & \\
\hline
\end{tabular}

(Chorley, Letters, 1: pp. 105-7). She continues to request plot suggestions throughout the year, as revisions to and rejections of Foscari, together with the unexpected embarrassment of Lord Byron's publication of The Two Foscari late in 1821, leave Mitford casting about for new ideas. After many frustrations over rewriting parts to suit the rival actors Macready and Charles Kemble, Mitford's Foscari would finally be performed at Covent Garden in 1826. Disappointed in her efforts with the theaters, her letters in the mid-1820s contain many pleas for guidance in more profitable modes of writing. In July 1824, she asks Harness about the feasibility of her writing a novel (L'Estrange, Life, 2: p. 185), a question she repeats to Jephson in August. Notably, Mitford details her circumstances in far more personal detail when writing to Jephson. Mitford shares that Rienzi is slated for performance in the next season, but notes that this is 'a matter strictly confidential' as Macready 'talks of bringing it out as if written by a man, to avoid the great annoyance of newspapers, etc., so unpleasant to a female writer'. Mitford is looking for a new project while she is 'writ[ing] as usual for magazines'. She has been urged to write a novel 'by almost everyone who has read [her] little volume', but she is 'half afraid' of the genre. Instead, she is 'more inclined to try a second volume of "Our Village", for which there are plenty of materials close at hand'. She asks Jephson, 'What do you advise?' (L'Estrange, Life, 2: p. 187). As she had earlier with Hofland, Mitford seems to offer her women correspondents opportunities to alter her plots, inviting them to brainstorm collaboratively.

The expansion of Mitford's network in the early 1820 s is not only so that she can solicit advice. As she had earlier importuned her father on behalf of Miss 
Table 6.5: Letters to Specific Recipients, 1826-30

\begin{tabular}{lclc}
\hline Distinct Recipients & Count & Distinct Recipients & Count \\
\hline Harness, William & 23 & Ricketts, Miss & 1 \\
Talfourd, Thomas Noon & 18 & Shoberl, Frederic & 1 \\
Elford, William & 18 & Davenport, Richard Alfred & 1 \\
Jephson, Emily E. & 18 & Colman, George, Jr. & 1 \\
Haydon, Benjamin Robert & 11 & Lord Chamberlain & 1 \\
Mitford, George & 9 & Bentley, Richard & 1 \\
Wrangham, Francis & 7 & Roscoe, T. & 1 \\
Hofland, Barbara & 6 & Hodgkinson, Mrs. & 1 \\
Mitford, Mary Russell & 4 & Ackermann, Rudolph & 1 \\
Russell, Mary & 4 & Jerrold, Douglas & 1 \\
Lucas, John & 3 & Cooper, John & 1 \\
Colburn, Henry & 3 & Young, Charles Mayne & 1 \\
unknown & 3 & Hemans, Felicia & 1 \\
Hall, Anna Maria Fielding & 2 & Kemble, Charles & 1 \\
Sedgwick, Catharine Maria & 2 & Dickinson, Mrs. & 1 \\
Hofland, Mr. & 1 & Dyce, Rev. Alexander & 1 \\
Sidmouth, Lady & 1 & Valpy, Abraham & 1 \\
\hline Total & & & 150 \\
\hline & & &
\end{tabular}

Rowden, Mitford is now sometimes acting on her own behalf and that of her friends. Some of her single letters are for this sort of professional activity. She sends her poem praising the prominent Englefield House to its owner, Richard Benyon in June 1822, ${ }^{34}$ and she sends Hamilton a story for Lady's Magazine on 9 April 1823, while describing another that she is composing about the North of Hampshire, which she mentions 'because perhaps on account of the subject [he] might like to keep room for it'. ${ }^{35}$ Most significantly, Mitford tells Hofland on 14 June 1822 that her article on Hofland's 'Tales of the Manor' is appearing in that week's Museum, and adds that she 'shall try to make [her] way in other quarters' (Chorley, Letters, 1: p. 118). Here, Mitford is leveraging her experience with magazine publishing to attract notice to her friend's story, effectively taking on the role of literary agent which she had needed earlier in her own career.

34 Letter at the Berkshire Record Office.

35 Letter at Reading Central Library. 
With the success of her plays and Our Village, Mitford's correspondence grows exponentially. She writes about the same number of letters in the late 1820 s as she has earlier in the decade, but to nearly double as many recipients. Table 6.5 captures the state of flux of Mitford's network. Jephson, for example, becomes a much closer confidante, as evidenced by the more than double number of letters to her. Harness becomes instrumental in Mitford's network, receiving more letters than anyone else. Countering these increased frequencies, three of Mitford's most significant recipients, Elford, Hofland and Talfourd, appear to receive far fewer letters in these years. Elford's decline in centrality in Mitford's network takes another precipitous drop from 50 letters earlier in the decade to 18 in its latter half. At the same time, Hofland appears to receive half as many letters are previously, and Talfourd two-thirds fewer. However, the content of the letters indicates that both Holfand and Talfourd remain Mitford's close friends. She eagerly anticipates the publication of Hofland's 'Moderation' in a letter from 25 May 1825 and 'Beatrice' from one from 24 September 1829. The September 1829 letter also contains Mitford's reassurances that they are 'too dear friends to stand on [that] kind of ceremony' in which one must wait for a letter from the other before writing again (Chorley, Letters, 1: pp. 130, 137-8). Despite their apparently less-frequent exchanges, Mitford also continues to confide in Hofland, outlining in her 25 May 1825 letter her plans for a novel 'as like Miss Austen' after she finishes writing Charles $I$, describing her irritation over not being paid in a timely fashion in 20 September 1826, and detailing how her and her mother's health concerns caused her to be unable to write in 13 March 1829 (Chorley, Letters, 1: pp. 129, 131-3, 135). Talfourd, too, remains in Mitford's inner circle despite receiving fewer letters from her. In an undated letter apparently from 1828, Mitford opens by calling Talfourd her 'always best and kindest friend', and refers to her lingering uncertainty about Macready's treatment of her play Rienzi, 'his criticism goes near to prove that he has forgotten the play, which is undoubtedly too much condensed'. She tells him that she is weighing whether to write a novel - again referring to Jane Austen - or to 'take [his] advice as to Magazine writing. ${ }^{36}$ These letters to Hofland and Talfourd suggest that Mitford's frustrations with getting her plays staged leads to a kind of holding pattern in the late 1820 s while she determines which genre to attempt next.

The doubling of Mitford's network in the second half of the 1820s is due to 16 new correspondents in this period, nearly all of whom are related to her literary career. The largest number of these is connected with various aspects of the theater, including actors (Charles Young and Charles Kemble), the Licensor of new plays who refused to sanction Charles I (George Colman, Jr.), and an up-and-coming dramatist (Douglas Jerrold). She also writes to publisher Rudolph Ackerman and editor Thomas Roscoe, the latter of whom published Mitford's

${ }^{36}$ Letter in the John Rylands Library. 
story 'The Two Magpies' in his volume The Juvenile Keepsake in $1830 .{ }^{37}$ Anna Maria Hall and Felicia Hemans join Mitford's growing circle of female writers at this time. The breadth of her contacts in all aspects of publishing reinforces Mitford's position as a significant literary figure of her day, while her letters' contents emphasize the significant extent to which men controlled the industry and thus, controlled which women's voices reached a wider audience. Mitford's ongoing efforts to recruit women writers to contribute to annual collections of short stories goes beyond the self-interest of ensuring that the editor had enough material to go to press. Her letters to these new correspondents reflect a strong interest in promoting their writing and sharing leads and ideas - and we see the expansion of a co-operative network of literary women.

The 1830s bring even more letter-recipients into Mitford's sphere, with nearly two dozen new people joining her ongoing communications, as shown in Figure 6.6 and Tables 6.6 and 6.7.

Table 6.6: Letters to Specific Recipients, 1831-35

\begin{tabular}{lclc}
\hline Distinct Recipients & Count & Distinct Recipients & Count \\
\hline Talfourd, Thomas Noon & 20 & Morton, Thomas & 1 \\
Jephson, Emily E. & 18 & Weirdon, Miss & 1 \\
Mitford, George & 16 & Smith \& Elder, Messrs. & 1 \\
Elford, William & 13 & Trollope, Frances Milton & 1 \\
Harness, William & 7 & Pringle, Thomas & 1 \\
Bentley, Richard & 7 & Hughes Senior, Jane Elizabeth & 1 \\
Devonshire, Duke of & 5 & Burke, J. & 1 \\
Glenny, George & 3 & Berkshire Chronicle & 1 \\
Mitford, Mary Russell & 3 & Hayward, Abraham & 1 \\
unknown & 2 & Richards, J. & 1 \\
Hall, Anna Maria Fielding & 2 & Bentley, Samuel & 1 \\
Greene, John Hooke & 2 & Yates, Mrs. & 1 \\
Shoberl, Frederic & 2 & Hanmer, Mrs. & 1 \\
Redding, Cyrus & 2 & Phillips, Henry & 1 \\
Merry, Mrs. & 2 & Sedgwick, Theodore & 1 \\
Colman, George, Jr. & 1 & Bennett, Octavian & 1 \\
\hline Total & & & 121 \\
\hline
\end{tabular}

${ }^{37}$ Mary Russell Mitford, 'The Two Magpies' in The Juvenile Keepsake, ed. Thomas Roscoe (London: Hurst, Chance \& Co., 1830) pp. 95-100. Accessed on Google Books 27 July 2016. 
Women's Literary Networks and Romanticism

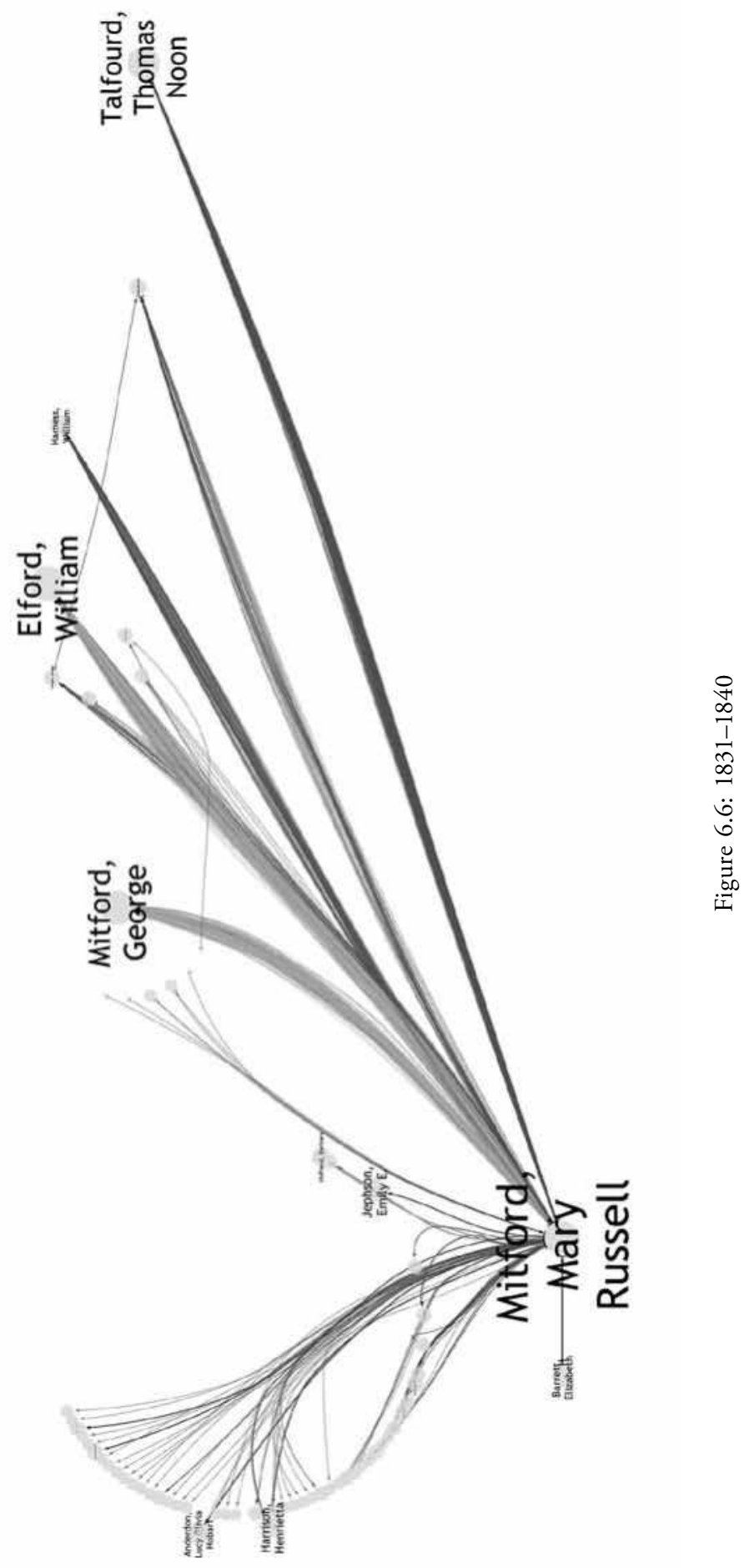


As with the new correspondents of 1826 to 1830 , many of the new letterrecipients of 1831-5 are involved in writing and publishing. Samuel and Richard Bentley, Frederic Shoberl, Henry Colburn, Cyrus Redding, Thomas Pringle, and Messrs. Smith \& Elder edit and publish various works of Mitford's in collections and magazines during this phase of her career, while the Duke of Devonshire confirmed George Colman's earlier rejection of Charles I (L'Estrange, Life 2: p. 313). Writers with whom Mitford began correspondence include Abraham Hayward, Thomas Morton, Catharine Maria Sedgwick, and Frances Milton Trollope. Mitford's exchange with Trollope is especially interesting, as it points to Mitford's status as a crucial voice for other women. On 21 May 1831, Trollope writes to Mitford from New York, before returning home to England after living in the United States for four years. Trollope requests that Mitford write a letter of introduction to her publishers, to smooth the way for Trollope's arrival. She writes, 'I am well aware that it is difficult to bring a first effort to the light, but I think your powerful name will help me much' (L'Estrange, Friendships 1: p. 163). In a follow up letter of 16 September 1831, Trollope thanks Mitford for the 'very kind manner' with which she had complied with Trollope's request and informs her of her manuscript's favorable reception with the publisher and reviewer (L'Estrange, Friendships 1: p. 164). Whittaker does, in fact, go on to publish Trollope's Domestic Manners of the Americans in 1832. This example of Mitford using her network to assist the careers other women is particularly powerful, as Trollope would go on to be quite successful, publishing additional travelogues and novels throughout the next two decades.

The late 1830s continues the prolific and spreading network of Mitford's correspondence, with 249 recorded letters to 42 distinct recipients, represented in Table 6.7. Of these, Mitford herself was the recipient of 87 letters, 82 of them written by Elizabeth Barrett. The momentous year that marked the beginning of Mitford's famous mentoring friendship with Elizabeth Barrett was 1836. According to Melinda Creech's posting on the Baylor University Armstrong Browning Library and Museum blog, 'EBB corresponded with Miss Mitford for nearly two decades and wrote more letters to her than to any other person., ${ }^{38}$ The Mitford-Barrett correspondence is well documented in Meredith Raymond and Mary Rose Sullivan's edition of 1983, The letters of Elizabeth Barrett Browning to Mary Russell Mitford, 1836-1854 and in The Browning's Correspondence: An Online Edition (browningscorrespondence.com), which provides helpful date corrections for letters misdated in L'Estrange's edition of Mitford's letters though only excerpts

${ }^{38}$ Melinda Creech, 'Armstrong Browning Library Benefactors Day 2013 Exhibit,' Armstrong Browning Library and Museum, 16 October 2013, https://blogs.baylor.edu/ armstrongbrowning/tag/mary-russell-mitford. Accessed 2 October 2017. 
of those letters as published in the L'Estrange volume. We have a far better record of Barrett's letters sent to Mitford than vice versa, and through the years of their correspondence, which lasted until Mitford's death in 1855, it seems as if they corresponded regularly multiple times per month. Although sometimes we have a record of only one letter from Mitford to Barrett per month, given the nature of her correspondence with close friends like Hofland, Emily Jephson, and Elford, we expect there are more letters from Mitford to Barrett to be located. A sample of Mitford's writing to Elizabeth Barrett in a letter L'Estrange dates 29 December 1844 illuminates something of Mitford's mentorship in suggesting topics of her younger friend for narrative poetry, as well as her abiding interest in Napoleon:

I am enchanted to find that you mean to write narrative poetry, and narrative poetry of real life. We must talk over subjects and stories. I still wonder that Napoleon does not inspire you. Oh, what a man! I would have given a limb to have been in the place of Madame Rechard or Madame de Montholon, or even of one of the Miss Balcombs - ay, or to have been concealed somewhere just to have heard him conversing and dictating, but rather conversing. After all, his prophecies are realized. He is the glory of France. Louis Philippe would hardly have sat on the throne so long had he not called in the memory of its idol to fix him in the love of the nation. (L'Estrange, Life, p. 189)

Mitford's interest in Napoleonic subjects and epical narrative poetry persisted long after she had produced her own poems and historical tragedies on Napoleonic topics or topics of revolution and civil war for the stage (Julian, Foscari, Rienzi, Charles I), and her interest in the conversation of the emperor with women or as overheard by women seems striking here as a subtle hint for a topic of a new poem. Though we have not identified Madame Rechard, the other women mentioned here interacted with Napoleon during his exile on the isle of Elba, before his Hundred Days return to power in 1815, followed by his decisive defeat at the Battle of Waterloo. Barrett seems to have interested herself more in current events as the topic of poetry, though as Elizabeth Barrett Browning she would publish, in 1860, a volume titled Napoleon III in Italy and Other Poems, with the title poem directly addressing the then-current emperor of the Second French Empire.

We have been representing filtered views of the network graph of Mitford's correspondents to help document the expansion of the network in these decades. After 1840 and even in the last five years of her life (between 1850 and 1855) new correspondents emerge, but others fade or are no longer recorded. The most significant of those absent in the 1840s are her father and Sir William Elford, both of whom died in the mid-1830s. We document Mitford 
Table 6.7: Letters to Specific Recipients, 1836-40

\begin{tabular}{|c|c|c|c|}
\hline Distinct Recipients & Count & Distinct Recipients & Count \\
\hline Mitford, Mary Russell & 87 & Dacre, Lady & 1 \\
\hline Talfourd, Thomas Noon & 31 & Howitt, Mrs. M. & 1 \\
\hline Barrett, Elizabeth & 15 & Joy, Miss & 1 \\
\hline Jephson, Emily E. & 13 & Dawson, Mr. & 1 \\
\hline Mitford, George & 12 & Marshall, Miss & 1 \\
\hline Anderdon, Lucy Olivia Hobart & 12 & Croft, Dowager Lady & 1 \\
\hline Harrison, Henrietta & 11 & Bogue, David & 1 \\
\hline Harness, William & 11 & Williams, Miss & 1 \\
\hline Sedgwick, Theodore & 11 & Gulson, Mrs. & 1 \\
\hline Devonshire, Duke of & 4 & Holland, Mrs. & 1 \\
\hline Tilt, Charles & 3 & Boyne, D. & 1 \\
\hline unknown & 3 & Kenyon, John & 1 \\
\hline Martin, Albinus & 3 & Reeve, Henry & 1 \\
\hline Bennett, Octavian & 2 & Moulton-Barrett, Arabella & 1 \\
\hline Elford, William & 2 & Hayward, Abraham & 1 \\
\hline Hofland, Barbara & 2 & Jerrold, Douglas & 1 \\
\hline Horne, Richard Henry & 2 & Lucas, John & 1 \\
\hline Trollope, Frances Milton & 1 & Moulton-Barrett, Henrietta & 1 \\
\hline Lockhart, Miss & 1 & Yates, Miss & 1 \\
\hline Dickinson, Mrs. & 1 & Lovejoy, George & 1 \\
\hline Gandy, Edward & 1 & Cockburne, Mrs. & 1 \\
\hline Total & & & 249 \\
\hline
\end{tabular}

as receiving 322 letters between 1841 and 1845, 316 of them from Elizabeth Barrett, leaving us a record of only 162 letters from Mitford in these years.

Was there a decline in her letter writing, or is the record simply incomplete? We suspect the latter. In all of our network graphs, the nodes are arranged by 'out-degree', or the numbers of letters sent by a particular individual. In Figure 6.7, those with the highest total out-degree in the entire network are Mitford (1,766 recorded letters to others), Barrett (479 to Mitford), John Ruskin (13 to Mitford), and Talfourd (9 to Mitford), and the network graph arranges the nodes so that those with the highest out-degree are stacked at the bottom and at the far right. The cluster of people at the top left who 


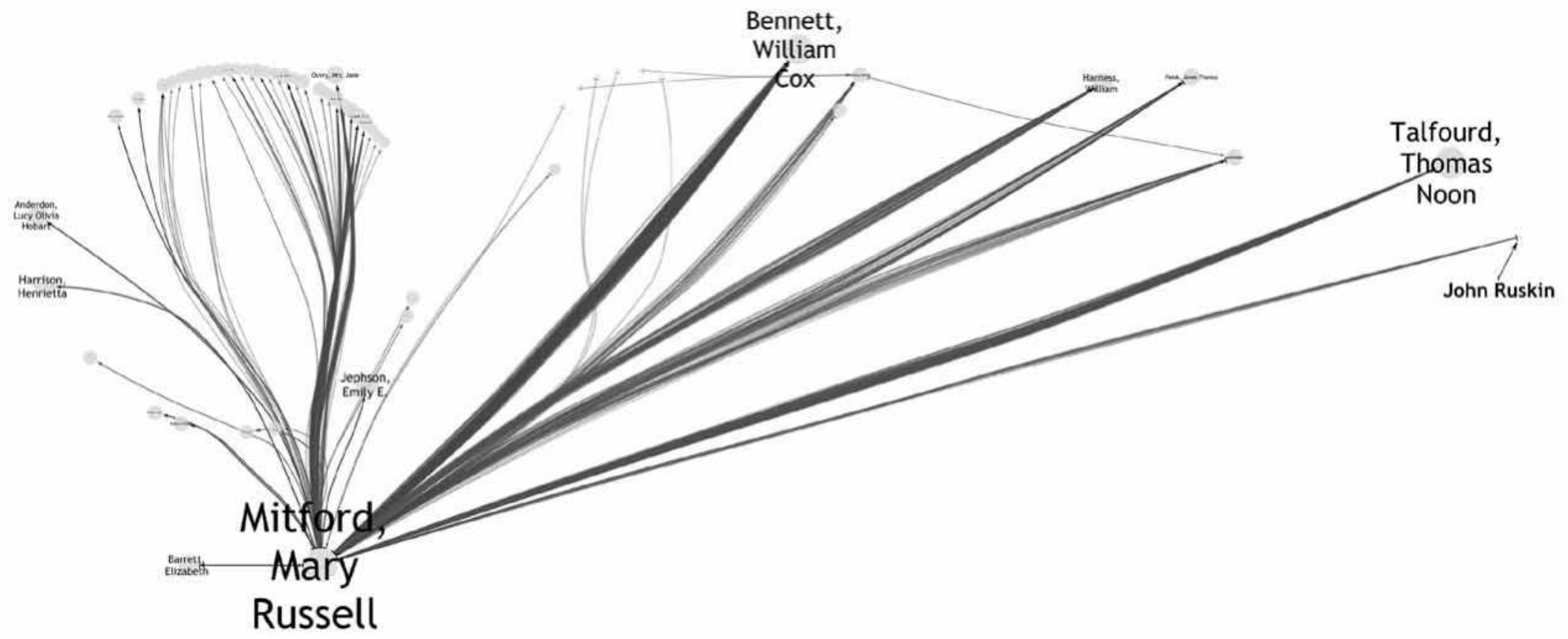

Figure 6.7: 1841-1850 
Table 6.8: Letters to Specific Recipients, 1841-5

\begin{tabular}{lclc}
\hline Distinct Recipients & Count & Distinct Recipients & Count \\
\hline Mitford, Mary Russell & 322 & Buckingham, J. & 2 \\
Barrett, Elizabeth & 44 & Lucas, John & 2 \\
Anderdon, Lucy Olivia Hobart & 26 & Mitford, Robert Osbaldeston & 2 \\
Harrison, Henrietta & 22 & Bennett, William Cox & 1 \\
Jephson, Emily E. & 15 & Hughes Senior, Jane Elizabeth & 1 \\
Lovejoy, George & 8 & Literary Fund & 1 \\
Talfourd, Thomas Noon & 6 & Devonshire, Duke of & 1 \\
Martin, Albinus & 6 & Robinson, Henry Crabb & 1 \\
Norton, Andrews & 5 & Cary, Mrs. & 1 \\
Horne, Richard Henry & 5 & Kenyon, John & 1 \\
Harness, William & 3 & Walker, Mrs. & 1 \\
Chorley, Henry Fothergill & 2 & Kirkby, James & 1 \\
Blewitt, Octavian & 2 & Anderdon, Mrs. Maria & 1 \\
unknown & 2 & & 484 \\
\hline Total & & &
\end{tabular}

form a full circle in the complete network share the same out-degree of zero, meaning we currently have not recorded any letters from them to Mitford or to anyone else in the network. This helps to account for the distinct shape of our graph. The 'circle' of nodes on the left reflects a diversity of correspondents with whom Mitford had sometimes extensive contact but which shifted over time. Of these first Barbara Hofland and later Emily Jephson stand out as important long-range correspondents, and we have not yet traced very much of their correspondence with Mitford at the time of this writing beyond the selections printed by L'Estrange and Chorley. ${ }^{39}$ It is important to note also that apparent rare or 'one-off' correspondents may only appear to be 'shallow' relationships: our archival records are necessarily incomplete. For example, though Table 6.8 shows that William Harness appears to receive only three letters from Mitford, we are aware that he knew both Mitford and Lord Byron

\footnotetext{
39 As we prepare this chapter for press in September 2016, new data from the Digital Mitford team is expanding our view of Mitford's female network. In addition to those represented here, we have traced 16 more letters from Mitford to Jephson, as well as 18 letters from Frances Trollope to Mitford, ten letters from Catherine Maria Sedgwick to Mitford, and six from Barbara Hofland.
} 
when they were all young, and he played an extremely important role in the preservation of Mitford's correspondence as her chosen literary executor. Her full correspondence with Harness is evidently missing as yet from our database, or perhaps the explanation is Harness's own habits of correspondence, as she wrote in a letter to Mrs. Acton Tindale of 4 September 1847, referring to Harness: 'I know my man - the very best friend that lives in the world, and one of the worst possible correspondents' (Chorley, Letters, 2: p. 16).

William Cox Bennett's substantial and as yet to our knowledge completely unpublished correspondence with Mitford appears to begin in the mid-1840s, as represented in Table 6.9. Bennett was one of a number of 'next generation' writers to seek out Mitford in the 1830s and '40s, including Barrett as well as some from the U.S.: Catherine Maria Sedgwick and Nathaniel Hawthorne. We also have correspondence documented with the Literary Fund, reflecting Mitford's sometimes pressing financial interests. She was successful and wellknown but had difficulty earning enough money to support herself by writing, just as she had had difficulty supporting herself and her parents by her pen while they were alive.

Table 6.9: Letters to Specific Recipients, 1846-50

\begin{tabular}{lclc}
\hline Distinct Recipients & Count & Distinct Recipients & Count \\
\hline Bennett, William Cox & 62 & Smith, Dora & 2 \\
Mitford, Mary Russell & 53 & Hughes, John & 2 \\
Ouvry, Mrs. Jane & 22 & Jameson, Anna Brownell & 1 \\
Anderdon, Lucy Olivia Hobart & 20 & Rigsby, R. & 1 \\
Harrison, Henrietta & 16 & Shoberl, Mrs. F. & 1 \\
Boner, Charles & 12 & Lovejoy, Miss M. & 1 \\
Lovejoy, George & 11 & Bentley, Richard & 1 \\
Barrett, Elizabeth & 7 & Bennett, W. L. & 1 \\
unknown & 6 & Dyce, Rev. Alexander & 1 \\
Fields, James Thomas & 6 & Moulton-Barrett, Edward & 1 \\
Haydon, Mary & 5 & Russell, Miss & 1 \\
Horne, Richard Henry & 5 & Pearson, Hugh & 1 \\
Jephson, Emily E. & 4 & Lovejoy, Patty & 1 \\
Jennings, Agnes & 3 & Hughes, Mrs. & 1 \\
Cockburn, Mrs. & 2 & Anderdon, Emma M. & 1 \\
\hline Total & & & 251 \\
\hline
\end{tabular}


The network graph in Figure 6.8 suggests a reduction in the number of correspondents in the last five years of Mitford's life, but the quantity of letters persists as usual: a recorded 382 letters from Mitford exist from this period, and new correspondents appear as well, including Nathaniel Hawthorne, to help complete the circle in the upper left of the graph. This is the period when J. T. Fields, the Boston publisher, and John Ruskin, the philosopher, were writing to Mitford, an index of her significance to influential writers and thinkers on both sides of the Atlantic in mid-century. Something of the transatlantic literary network is apparent in Mitford's frequent references to J. T. Fields as her friend in several letters to Jephson: Fields had visited her in Three Mile Cross and brought her news of Hawthorne, which she relayed to her friends. Jephson, for her part, copied this part of Mitford's letter to her friend Digby Starkey in a letter of her own, illuminating something of the quotable significance of a letter from Mitford in these last years of her life. Of Nathaniel Hawthorne, Mitford wrote,

Magnificently beautiful, and gifted, as you see, and educated at the same college, and with the same advantages as Longfellow, he was, three or four years ago, without vice or extravagance on his part, literally starving. My friend, Mr. Fields, heard of it (he is a partner in the great publishing house in America), and being a man of fine taste, as well as fine feeling, and having seen some of Hawthorne's magazine articles, he went to him and said, 'I have such a faith in you that, if you will give me a book, I will print two thousand five hundred copies, run all risks, and allow you twenty-five percent'. The poor author demurred; he had begun a tale which was to form one of a volume of short stories, and showed him neither more nor less than the 'Scarlet Letter'. My friend, Mr. Fields, himself a poet said at once, 'This must not be one of a volume of short stories; it must be a fully developed tale['], and accordingly Mr. Hawthorne took his advice, and is now in comfort and affluence. (L'Estrange, Friendships, 2: pp. 180-1)

As Table 6.10 shows, Mitford remained as prolific a letter writer as ever up until the end of her life. In these last five years she was working on her collections of her own works and her reflections back on her career in drama. While her writings in these last five years take a retrospective turn, evidence of her awareness that her writings might one day be collected is apparent from much earlier stages, from the time of her youthful correspondence with Sir William Elford. And to the end, Mitford appears to have been reading as much as ever, taking a continuing interest in new writers and new literary productions - very much an active node in her literary networks to the last. 
Women's Literary Networks and Romanticism

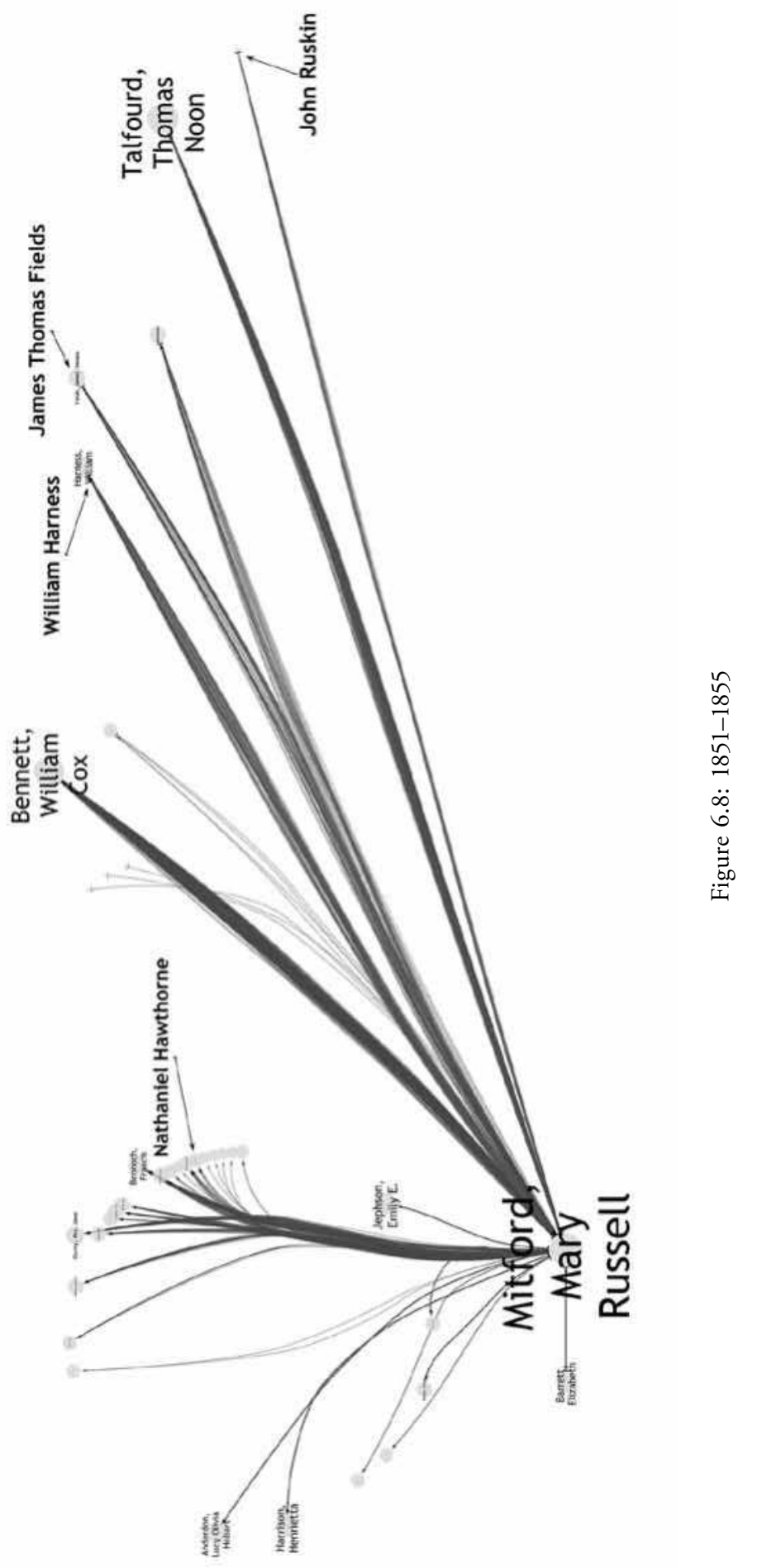


Table 6.10: Letters to Specific Recipients, 1851-5

\begin{tabular}{lrlc}
\hline Distinct Recipients & Count & Distinct Recipients & Count \\
\hline Bennett, William Cox & 101 & Anderdon, Lucy Olivia Hobart & 4 \\
Bennoch, Francis & 59 & Lucas, John & 4 \\
Mitford, Mary Russell & 57 & Hawthorne, Nathaniel & 4 \\
Fields, James Thomas & 29 & Chorley, Henry Fothergill & 4 \\
Harrison, Henrietta & 27 & Starkey, Digby & 3 \\
Pearson, Hugh & 22 & Barrett, Elizabeth & 3 \\
Ouvry, Mrs. Jane & 19 & Hughes, John & 2 \\
Russell, Miss & 13 & Parsons, Thomas William & 2 \\
Goldsmid, Anna Maria & 12 & Hughes Senior, Jane Elizabeth & 1 \\
Hoare, Mary Anne & 11 & de Goodrich, Miss & 1 \\
Harness, William & 11 & Trollope, Frances Milton & 1 \\
Bentley, Richard & 10 & Robinson, Henry Crabb & 1 \\
Jennings, Agnes & 9 & Tuckermann, Henry T. & 1 \\
Jephson, Emily E. & 9 & Stoddard, Richard Henry & 1 \\
Boner, Charles & 8 & Brightwell, Cecilia Lucy & 1 \\
unknown & 8 & Dean, Mr. & 1 \\
\hline Total & & & 439 \\
\hline
\end{tabular}

The 'Test Bed':

\section{A Close-Up Investigation of 1819-25 and a Sample Letter}

The networks and data represented in the previous section all come from our database of information about Mitford's correspondence. We now turn to investigate the network of information about people and publications from within the writings by Mitford that we have been encoding in the project so far, concentrating on a short and transformative series of years in Mitford's life. We began our project with editing a first cluster of letters written between 1819 and 1825, together with Mitford's introduction to her self-collected Dramatic Works (1854), her plays Julian, Rienzi, and Charles I, and the first edition of her sketches in Our Village (1824). We added the late 1854 work because Mitford's introduction helps to serve as an introduction to the people to whom and about whom she was writing as she involved herself with the theater world of the 1820s.

A letter from Mary Russell Mitford to Mary Webb of 10 January 1819, transcribed and annotated by Digital Mitford editor Lisa Wilson, illustrates 
what has been missing from our distant reading survey and published records of Mitford's letters. Our distant reading marked out particular correspondents who stood out as recipients of the most letters over long stretches of time. The letter we discuss here was never published before in the previous editions of Mitford's letters, not even in part. The letter is part of an unbound collection of loose leaf manuscripts archived at the Reading Central Library, and is one of a series of letters written between 1815 and 1822 to Mary and Eliza Webb, daughters of a local brewer in Wokingham who were evidently close friends with the Mitfords at this time. Though Mary and Eliza Webb do not appear to be part of Mitford's publication network, Mitford's letters to them suggest she was either sharing her reading with them or guiding their reading. The letter we excerpt below demonstrates the quantities of reading material that Mitford regularly consumed and on which she expected her correspondents to be conversant. The Webb letters are also full of social details of gatherings, in this case a ball and extended visit with mutual friends, the Dickinsons. At the ball Mitford was snubbed for being 'Blue-ish', which generates from her a lively and entertaining satire of the snubber, perhaps in imitation of Thomas Love Peacock, whose work she has lately been reading:

I take it for granted, my dear Friend, that Eliza gave you all the particulars of the Ball - We wanted you very much indeed - which was a proof that the ball was worth going to. It had indeed great elegance, great sociability, a delightful host, an enchanting hostess $-\&$ above all it had Mr. Crowther. This man kept me alive \& lifelich (as old Chaucer says) all the evening. Oh my dear Mary I would give a great deal that you could see him - You have never seen anything like him - never unless you have seen a wasp in a Solar Microscope (an insect turned into a monster) - or unless you can imagine a Brobdingnagian Hourglass but neither wasp nor hourglass are small enough in the waist for this Dandy - this Exquisite - I have all my life had a great respect for the mechanical inventions of this age, but nothing that I have ever seen has given me such an idea of the power of machinery - not your Father's melting machine - not the Portsmouth Blockhouses - not the new Mint - as that wonderful effort of mechanism by which those ribs are endued in those stays. I do think he must have had one or two ribs broken on each side to make them lie closer. The compression would be incredible without some such expedient. But I am unjust in talking so much of the stays when it is the Altogether that is so perfect. Trowsers, Coat, handkerchief, shirt collar, head inside $\&$ out, all were in exact keeping - all belonged to those inimitable stays \& could not have belonged to any thing else. I never took such a fancy to any thing in my Life - I have seen nothing at all equal to it - Since Liston in Lord Grizzel - It 
was quite the charm of the evening to me at least, such a charm as a top is to a schoolboy - or a hoop - or as my grave cat Selim is to my frisky puppy Miranda. I am sorry to say the admiration was by no means mutual. The Dandy was an ungrateful Dandy - \& [Gap: 1 word, reason: illegible.] away at the sound of my voice just as Mossy (begging Mossy's pardon for the comparison) flies off at the sight of our dog-hating cook. He told a discreet friend who told me that he had an 'idea' (a very bold assertion by the bye) 'an idea that I was Blueish'. - Mr. Dandy Good Night - Thank you for a great deal of the best thing in the world - a great deal of laughter.

The passage illustrates how Mitford incorporates literary references into life events, so that Chaucer and Swift and the pantomime play Tom Thumb (featuring the actor John Liston as Lord Grizzel) combine to lend force to Mitford's satire of Mr. Crowther's artifice. The paragraph functions as the forceful retort of a woman of letters reveling in her very learning. Following the ball Mitford engaged directly in social literary activities with her hosts, the Dickinsons. Her description of listening to a recitation of Dante in English and Italian simultaneously illustrates her own taste and skill, as she must copy out and partially translate a section which she finds especially delightful. Mitford's letter shows how literary texts - and their imperfect copies - circulate among various reading and listening audiences in the nineteenth century.

In the evening we had a good deal of literature, English \& Italian. Mr. Dickinson read me some fine Translations from Dante \&c - with one of which I was so charmed as to beg a Copy - to my sorrow. The copy was graciously granted on condition that $I$ would transcribe it for the Author - to which polite request I of course acceded, quite forgetting that my accomplished friend wrote a fine rapid crabbed learned-looking hand which might pass for Greek or Persian or Arabic just as well as for English. So that I have been obliged to copy this translation - half from recollection - half from guess $-\&$ half from the original Italian. (Eliza who is so great an Arithmetician must tell you how I can be divided into three halves by any but an Irish method of Calculation) I have however done it at last $\&$ some time or other I will read it you. It is the celebrated Episode of Count Ugolino in Dante's Inferno.

After this account of a literary social engagement, we see Mitford at her most densely allusive, surveying and opining on her latest reading. The titles of published, exhibited, and performed works of art and literature that Mitford references together within the same paragraph of a letter help to document what Mitford was reading and viewing and how she circulated writings in 
her social network - here, what she has been reading since she returned home from her visit to the Dickinsons. Besides all six volumes of Edmund Burke's writings, she has been reading Henry Bradshaw Fearon's Sketches of America: A Narrative of a Journey of Five Thousand Miles through the Eastern and Western States of America (1817) as well as Peacock's Nightmare Abbey (1818), and relates these to other works she has read. Mitford calls Fearon's Sketches of America 'an antidote to the poison' of Morris Birkbeck's Notes on a Journey in America and Letters from Illinois, which as Lisa Wilson observes in her gloss, were 'much-read works, which presented a utopian, anti-clerical, and anti-aristocratic vision of American settlement' that likely encouraged emigration from Europe to the North American prairies. The ease and assurance with which Mitford recommends Peacock and Fearon while mentioning other works as inferior points to her role as an arbiter of literary taste within her network.

Ever since I have been at home as quiet as a mouse - reading all day long. First of all I have read 6 Volumes of Burke - of which I will have the compassion not to talk at present - you don't want to hear about old pamphlets, old speeches \& old American Wars - Then for the second time Mr. Fearon's very clever bran [sic] new book about America. I don't know any thing more agreeable than to have one's preconceived notions of a place or people confined by a good citable authority - a matter of fact authority who brings one in a tangible shape good reasons for old prejudices. This is the pleasure Mr. Fearon has given me. I always defended America \& the Americans (all but Franklin \& Washington) without very well knowing why - except that in that fair \& fresh \& beautiful world with every thing to inspire $\&$ incite them to excellence in Art \& Nature - they had done nothing \& they were nothing. Mr. Fearon has now added positive to these negative proofs $\&$ has fairly set them forth as the most boasting, vainglorious, ignorant, trumpery, second-hand, pawnbrokers-shop - sort of people that ever crept on the face of the earth. His book is invaluable $\&$ an antidote to the poison of Mr. Birkbeck's beautifully written but most deceitful works - an antidote the more powerful \& the more certain as coming from a friend to liberty $\&$ an admirer of the republican form of Government. I think you would like these Sketches of America - \& I am sure you would like a book which I have just finished - Nightmare Abbey. By far the best of Mr. Peacock's works - worth all his prose $\&$ all his poetry Melincourt $\&$ Rhododaphne included - Never was a more cheerful \& amicable piece of persiflage - full of laughing raillerie \& smiling philosophy Notwithstanding the gloomy title Nightmare Abbey is the most sunshiny book I have met with this many a day. It is a very clever attack upon mystical metaphysics \& misanthropical poetry (Deuce take Mr. Peacock 
for putting me to hard words!) and knocks them both completely down in the persons of my poor dear Friend Mr. Coleridge (alias Mr. Flosky) \& Lord Byron - not only knocks them down but dances on them being down, as his unruly subjects did on poor Sancho in the Island of Barataria. Nothing was ever better managed than the way in which Mr. Peacock contrives to put divers stanzas of Childe Harolde done into prose, into the Mouth of Mr. Cypress, the Lord Byron of the story. The book has another great merit. It is short.

Mitford's referencing of texts and authors presumes a high level of literary recognition on the part of Miss Webb, whom she apparently expects to be familiar with all the names, titles, and fictional references here. We have noted that this expectation is frequent in Mitford's long letters to her close friends, the Webb sisters, Sir William Elford, and Thomas Noon Talfourd in particular. Coding Mitford's detailed allusiveness to literary works opens up possibilities for studies of reception history, canon-formation, and the forming of public taste: Which authors and texts does she mention most frequently in her writings? Which ones is she reading at the same time (here, Fearon and Peacock), and which does she associate in relation or comparison to each other, as she associates Fearon's and Birkbeck's writings on America, and Peacock's Nightmare Abbey in comparison to his other novels, or in context with Byron's Childe Harold? Since Mitford often writes in her letters of what she has just been reading, the Digital Mitford editors include detailed markup in TEI XML code to track her references to the texts that she discusses with her correspondents. Here is a sample of the XML markup, featuring the portion of the passage about Nightmare Abbey:

I think you would like these <title ref="\#Sketches_of_

America">Sketches of America</title>—\&amp; I am sure you would like a book which I have just finished $-<$ title ref="\#NightmareAbbey">Nightmare Abbey</title $>$. By far $<\mathrm{pb}$ $\mathrm{n}=" 5$ "/> the best of $<$ persName ref="\#Peacock_TL">Mr. Peacock $<1$ persName>'s works—worth all his prose \&amp; all his poetry $<$ title ref="\#Melincourt">Melincourt</title> \&amp; <title ref="\#Rhododaphne" $>$ Rhododaphne $</$ title $>$ included-Never was a more cheerful \&amp; amicable piece of persiflage-full of laughing raillerie \&amp; smiling philosophy-Notwithstanding the gloomy title < title ref="\#NightmareAbbey">Nightmare Abbey<l title $>$ is the most sunshiny book I have met with this many a day. It is a very clever attack upon mystical metaphysics \&amp; misanthropical poetry (Deuce take <persName ref="\#Peacock_TL">Mr. Peacock</persName> for putting me to hard words!) and knocks them both completely down in the persons of my poor dear Friend 
$<$ persName ref="\#Coleridge_ST">Mr. Coleridge $<$ /persName $>(<$ del rend="squiggles" quantity="1" unit="chars" $><$ unclear $/></$ del $>$ alias $<$ persName ref="\#Flosky">Mr. Flosky</persName> \&amp; <persName ref="\#Byron">Lord Byron</persName $>$ - not only knocks them down but dances on them being down, as his unruly subjects did on poor <persName ref="\#Sancho_Panza">Sancho</persName> in the $<$ placeName ref="\#Island_Barataria">Island of Barataria</placeName>.

The angle-bracketed text represents XML tags, which are set in the passage to surround each proper name and title, both real and fictional. Other tags mark the structure of the document $(<\mathrm{pb}>$ for page break, for example) and record events in the writing of the manuscript ( $<$ del $>$ for a deletion, with the attribute rend='squiggles' indicating the curly loops Mitford applied to delete this passage). The markup adds editorial description and points to glosses we have written in a separate file we call our site index, which contains lists of named entities, people, places, fictional characters, and texts, among others. The tag <title ref="\#NightmareAbbey'> points to a bibliographic entry in our site index file that reads:

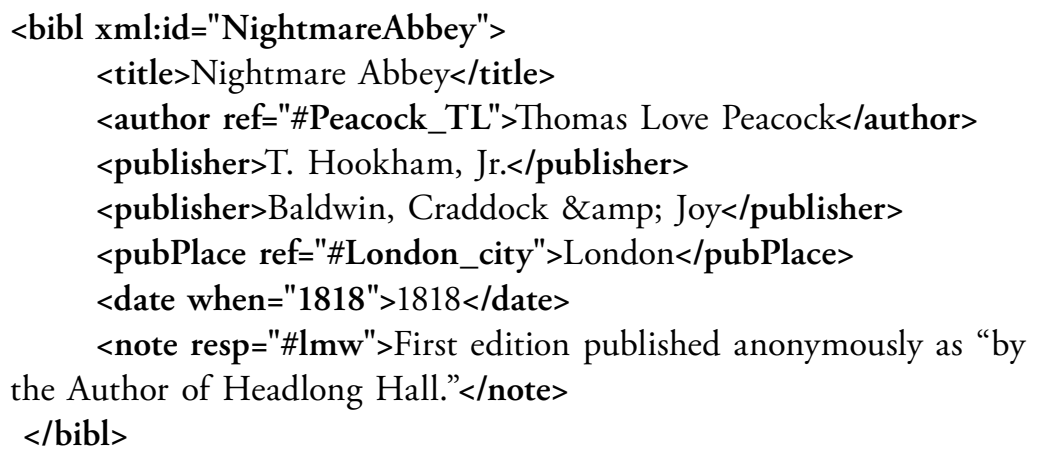

When we publish the edited letters on the Digital Mitford website, readers can mouse-over a name and retrieve information from the site index in a pop-up window. The full text of the current letter we are discussing is viewable in HTML from http://digitalmitford.org/getLetterText.php?uri=181901-10-MaryWebb.xml, or by choosing the year 1819 in our reading interface at digitalmitford.org/lettersInterface.html and selecting the letter dated '1819 January 10'. The marked-up names serve another function as well, in making it possible for us to follow how frequently a given name or text is mentioned in multiple letters, and what other names and texts are mentioned together in context with it. We might be curious to see how often Mitford references Peacock's Nightmare Abbey in the same paragraph of a letter with Fearon's Sketches of America, which apparently she did on at least one other occasion, in 
a letter to Barbara Hofland of 3 February 1819, not yet edited by the Mitford team but published in Chorley's edition. There she echoes the letter we feature here in a way which seems characteristic. That is, when she recommends books for one correspondent's attention, she frequently does so in much the same terms to another. In the letter to Hofland, Mitford wrote, 'Have you read Fearon's 'America?' You should. It would give you the pleasure it gave me. ... Then I have been laughing at 'Nightmare Abbey,' the pleasantest of Mr. Peacock's works, whether in verse or prose, 'Rhodo-daphne' and 'Melincourt' included,' and even proceeds to reference the identical passage of Don Quixote in comparison with Peacock's satire of Coleridge (Chorley, Letters, 1: pp. 41-2).

From such corresponding citations, we begin to see a network of co-referencing or co-citation emerging. That is, we can trace a network in which multiple letters share references of Peacock together with Fearon. This is a micro-example of the patterns which distant reading brings to the fore, highlighting that two seemingly unrelated texts are, in fact, connected through Mitford's reading habits and discussion in her letters. If distant reading identifies the creation and spread of literary taste against a backdrop of widespread reading, close reading analyzes how that taste functions. Given the vehemence with which Mitford delivers her opinion about Americans in multiple letters, we can see her repeated discussion of Fearon's text as a kind of evangelizing, perhaps to inoculate her correspondents against the pernicious influence of Birkbeck's deceitfully optimistic view of America. Examples such as this occur throughout the Digital Mitford's co-citation network.

\section{Networks of Co-Citation in Mitford's Writings}

The following network graphs and analyses are based on 75 edited TEI files ready for querying in our project, 70 letters plus about half of her journal from 1819 to '23, her prefatory material in Charles $I$, her introduction to the Dramatic Works, and the preface and opening sketches Our Village. Keeping in mind that there are probably many of Mitford's letters which scholars have not yet located and that Digital Mitford is in the early stages of transcribing and coding her works, including those letters in the L'Estrange and Chorley editions, the following visualizations introduce a cluster of interests that link Mitford's dramatic and prose production of the 1820s. To produce these networks, we worked with the structured hierarchy of TEI encoding to separate out the metadata - information about the letters' encoding, archival location, paper medium, etc. - to isolate the portions of files that represented Mitford's writing to an audience. We used XQuery ${ }^{40}$ to 'drill down' to the letters' body

${ }^{40} \mathrm{XQuery}$ is a programming language based on XPath, a syntax for navigating XML-encoded documents, including TEI documents. 
paragraphs, as well as the entries encoded thus far in Mitford's journal of 1819 to 1823 and her prefatory material to Our Village and the Dramatic Works. We specifically eliminated references to proper names contained in scholarly annotations by our own editors so that we could see who and what Mitford referenced directly, not what we think she might have been referencing or who or what might be relevant.

By giving us a glimpse of the people, fictional characters, and publications that Mitford wrote about most frequently in some association with each other, the network graphs below help to visualize the atmosphere in which Mitford thought and wrote, creating a snapshot of the unstated ephemera of daily life.

In studying 'co-citation' or 'co-occurrence' as a network of information, it is important not to overstate or assume 'direction'. In a directed network like the one of Mitford's correspondents discussed earlier in this chapter, we know who was writing to whom and when they wrote, and directionality clearly moves from writer to recipient. By contrast, the networks of Mitford's references to names and literature are undirected, meaning that they are based simply on the co-presence of named entities together in the same files. If a cluster of persons or texts appears frequently in multiple texts, we begin to see a pattern of strong connectivity emerging without being precisely sure of the cause. In her letters, Mitford frequently writes about more than one book or article she has been reading, and often she enquires about her correspondent's view of a particular novel by Scott or publication by Lord Byron. When a particular name appears frequently with many other names, that name has many 'edges', or connections to other nodes; the number of connections a node has to others is called its degree in network analysis. In the following graphs, we highlight the nodes with high degree by making them and their font labels larger to indicate the likelihood that they are especially significant. 'Distant reading' applied to networks of co-citation brings to light interesting patterns in a corpus of data too large for one scholar to distill on his or her own and illuminates possible areas for study with the fine-grain detail of close analysis.

One such area of interest for this volume on Romantic-era women's social networks is the question of the relative proportion of women to men that Mitford wrote about, considering her references to people and fictional characters. When we began this project, the Digital Mitford team expected to see a network mostly of women, and we were surprised to discover quite the opposite. Many of Mitford's most durable correspondents were men, and most of the real people as well as fictional characters and archetypes she mentions represent themselves as male. Figure 6.9 is a holistic co-occurrence graph that highlights the three kinds of 'people' we are tracing throughout Mitford's writings that we have encoded so far, and distinguishes them by sex with color codes. 


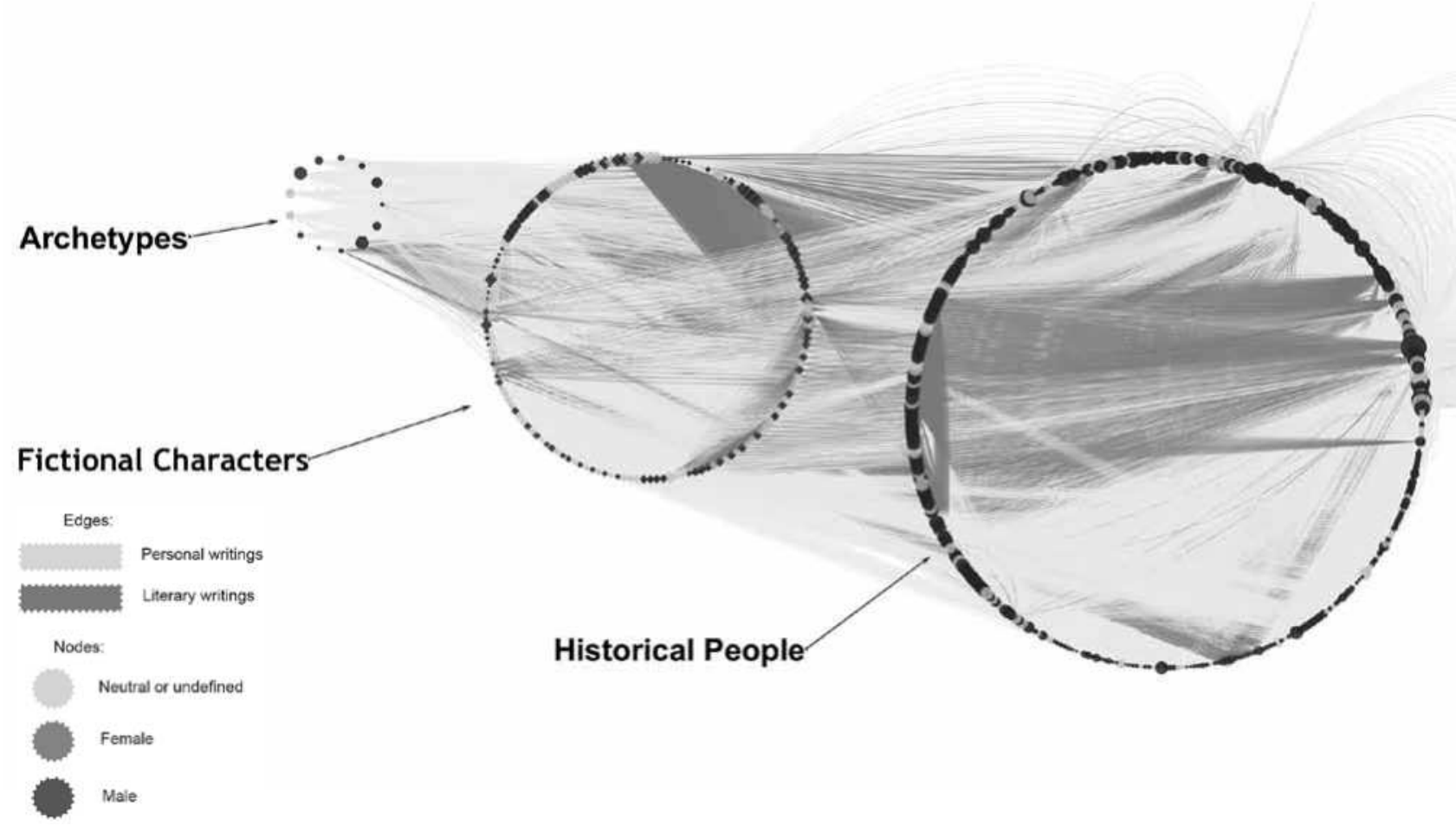

Figure 6.9: Co-citation network: What kind of "people" are mentioned together in Mitford's writings? 
The sizes of the three circles show that Mitford referenced a far larger variety of historical persons than of fictional characters from literary texts or of mythical archetypes. This network is very large, with close to 700 nodes and thousands of edge connections, so we cannot see the names of individual nodes, but it is already clear that there is a preponderance of male references in each of the three categories. To gain a clearer view of whether there is relatively greater emphasis on males in one particular grouping, we filtered the graph to show the historical persons and then the fictional personae separately. Figure 6.10 represents a distribution by known gender association of the historical individuals mentioned in Mitford's writings thus far, including her own and her friends' pets, who were as important to Mitford as the people she knew.

Figure 6.10 demonstrates two things clearly: 1) in the texts encoded so far, Mitford mentions males more frequently, and 2) the largest nodes on the graph - representing the most popularly mentioned individuals - are mostly male. These largest nodes include George Mitford (Mitford's father), Shakespeare, John Fletcher, Sir William Elford, William Macready. Two of the males with large degrees are historic playwrights, Shakespeare and Fletcher, which suggests their canonical significance at a moment when Mitford was aiming to succeed with her plays on the London stage. We also know that to succeed on that stage Mitford had to negotiate with William Macready, the actor-manager for whom she developed some of her most outspokenly radical male roles. Macready's significant presence in this co-citation network is a reflection of how frequently she mentioned him to her correspondents, particularly to Talfourd, in discussing her plays throughout the mid-1820s. This network view suggests the overwhelmingly male-dominated literary tradition and theatrical venues in which Mitford was angling to succeed. Nevertheless, the graph also features the strong presence of particular women of diverse significance: familial, political, and literary. The featured women include Mitford's mother, the well-read educator Miss James whom Mitford admired, and Lady Madelina Palmer, the wife of a Reading politician and a formidable presence in the local social scene.

This striking pattern is somewhat less extreme but still present in Mitford's references to fictional and archetypal characters, depicted in Figure 6.11.

The three separate 'rings' in Figure 6.11 represent three different networks within Mitford's writings. We see three separate rings because the network of fictional characters is broken; that is, not all of the writings coded so far discuss all of the fictional characters in common. We organized the female nodes on the left side of each circle and the male nodes on the right. As before, there are more males than females, but the disproportion here of 1.5 to 1 is not as extreme as with the network of historical persons. We do know that female characterization for the stage was an important emphasis in Mitford's plays and that may be why female characters are more written about than actual women. Mitford based her plays on historical material that featured men as 


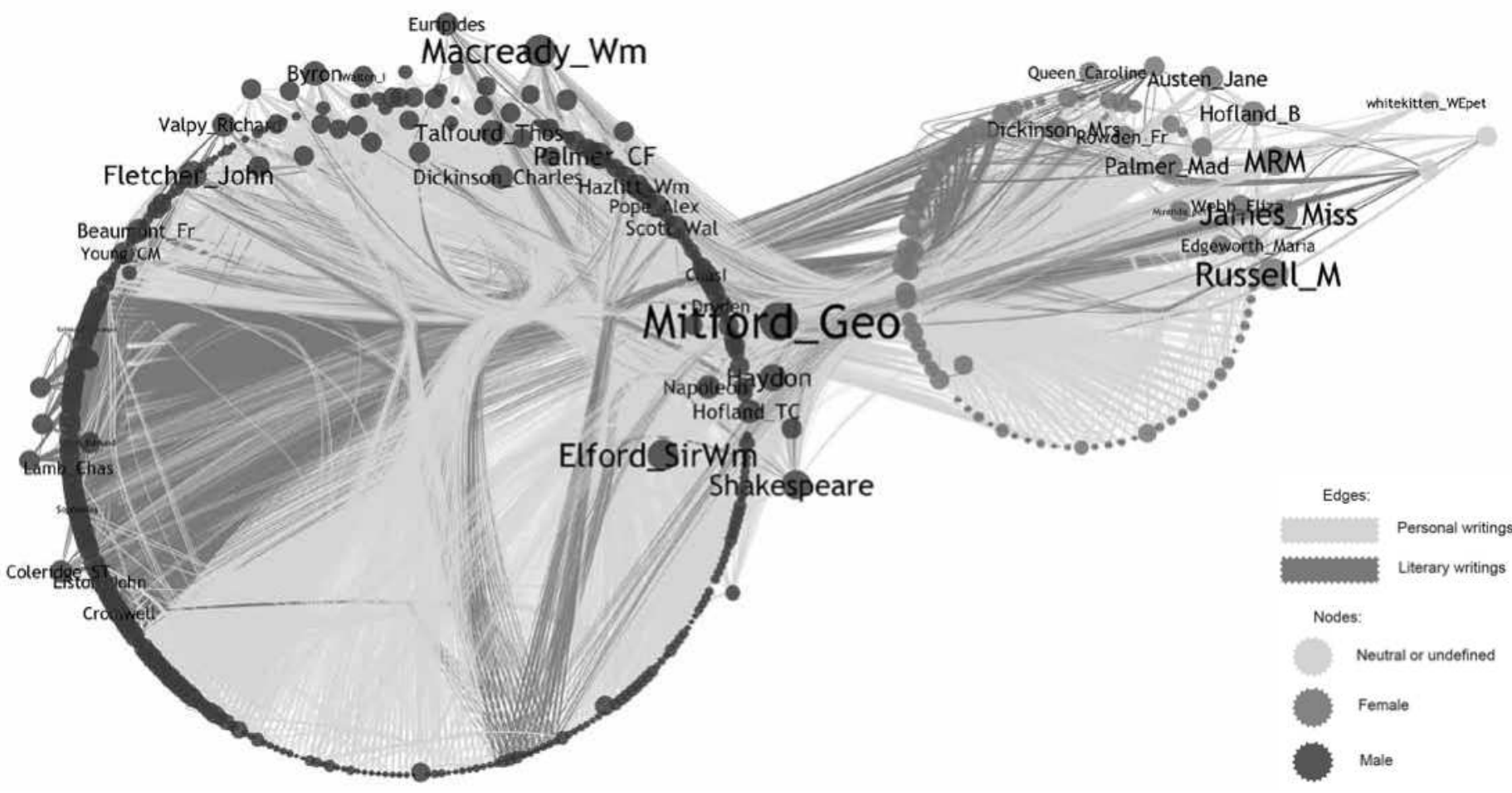

Figure 6.10: Co-citation network: Historical persons only, organised by sex 


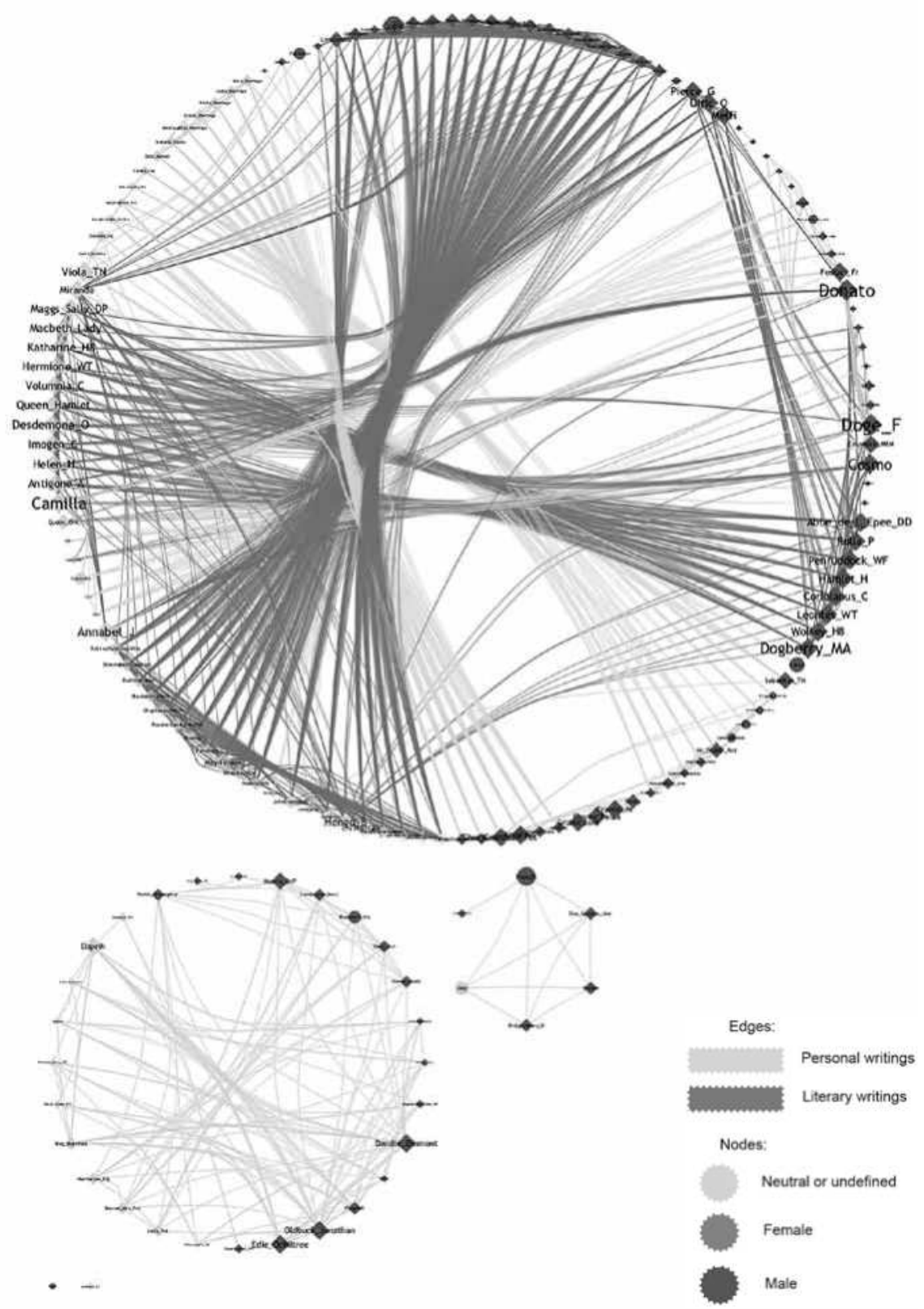

Figure 6.11: Co-citation network: Fictional and archetypal characters only, organised by sex 
key players in state crises, but she created female leads with major public roles in each plot.

Since Mitford wrote about fictionalized historical characters and actual persons all together, we considered that, too, to be a kind of networking of people and imaginary figures. She mentioned only two fictional characters, her Doge Foscari and Senator Donato (both characters in her play Foscari) frequently enough to be included in Figure 6.12, the network of the 32 most connected persons in the Mitford archive so far. ${ }^{41}$ Besides the two fictional characters, there are eight women and 22 men. The evident importance of the two fictional male characters reflects her preoccupation with the power dynamics between Macready and Charles Kemble, two actor-theater managers who contended for roles in Mitford's Foscari. We speculate that Mitford did not reference her other characters (including her own invented female characters) as frequently because they did not raise the controversies over performance parts that these two male roles did. Among the historical people in the 'top 32' network, Lady Madelina Palmer and Charles Fyshe Palmer are of unexpected interest as figures involved in local Reading politics, people whom Mitford appeared to find disagreeable yet who were highly popular and important in her local community. Frances Rowden was her teacher, with whom she attended plays and lectures in London while in school as a young woman, and Barbara Hofland was an author friend and frequent correspondent. While the mysterious 'Miss James' has been difficult for us to trace, Mitford mentioned her in letter after letter as a woman with interests in literary matters whom Mitford evidently knew and wanted to introduce to her correspondents. By far the majority of people in the 'top 32' network are connected to literary interests: Mitford's contemporaries Walter Scott, S. T. Coleridge, Lord Byron, Jane Austen, together with Pope, Dryden, Beaumont, and Fletcher, and Shakespeare from past centuries.

In addition to encoding the names of people and characters, the Digital Mitford team is tagging many other kinds of information: plant and animal species, organizations, fictional and real places, as well as publications and productions of multiple kinds: titled works of art and music, monographs, reference works in Mitford's time, and serial publications. Given Mitford's literary interests and the early goals of our archive to illuminate the literary and theatrical worlds the 1820 s, we have much to learn from tracking her references to published and performed works. For example, which works was she writing about most frequently during the years when she launched the plays and the first sketches that would become Our Village? How much

${ }^{41}$ We set our filter to show 32 people as a legible sample and because above the threshold of these 32, the nodes were of significantly lower degree. This number appeared to be a good threshold for visualizing the most popularly referenced individuals in Mitford's writing that we have coded so far. 


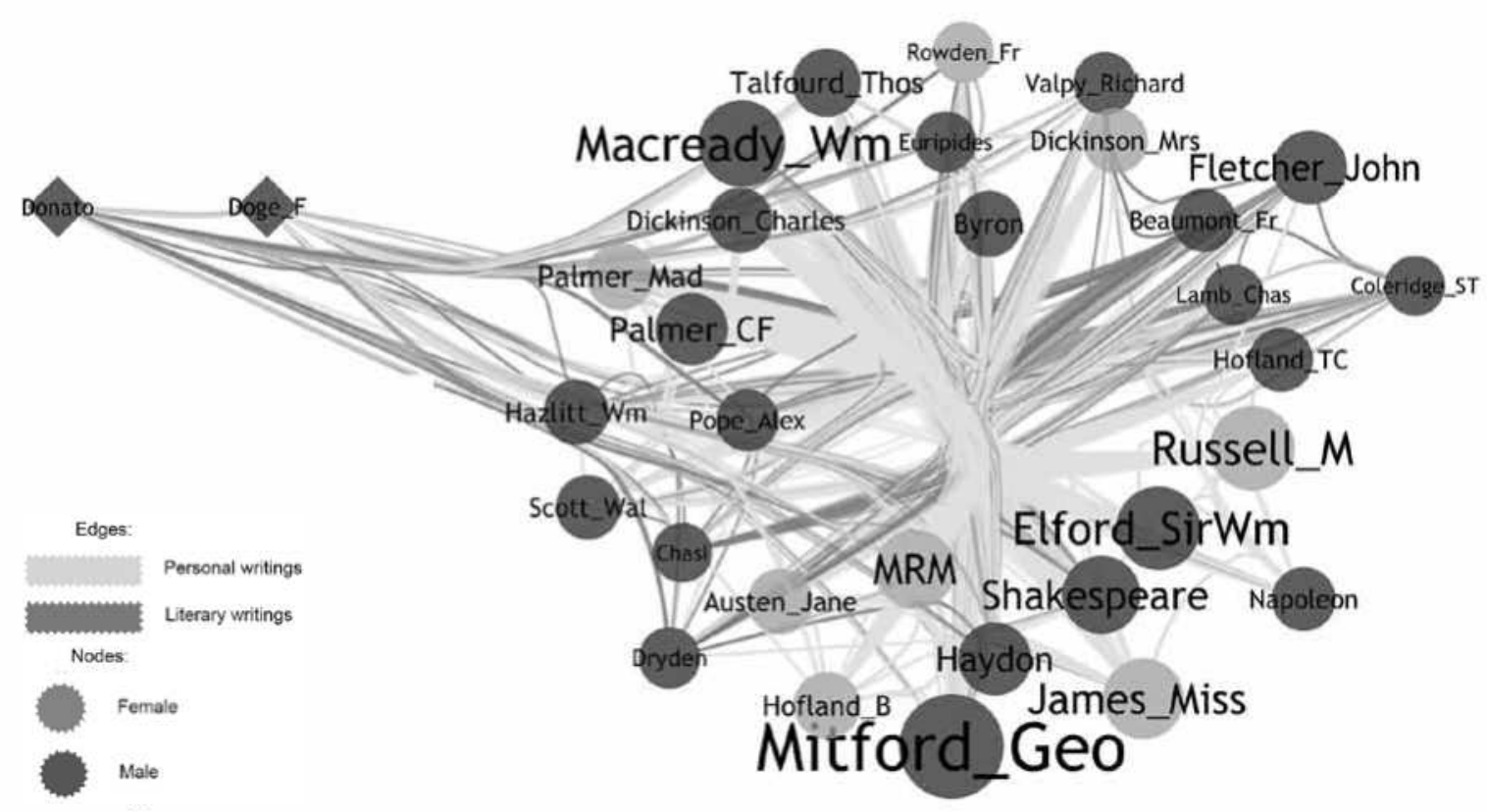

Figure 6.12: Co-citation network: Top 32 most connected people 


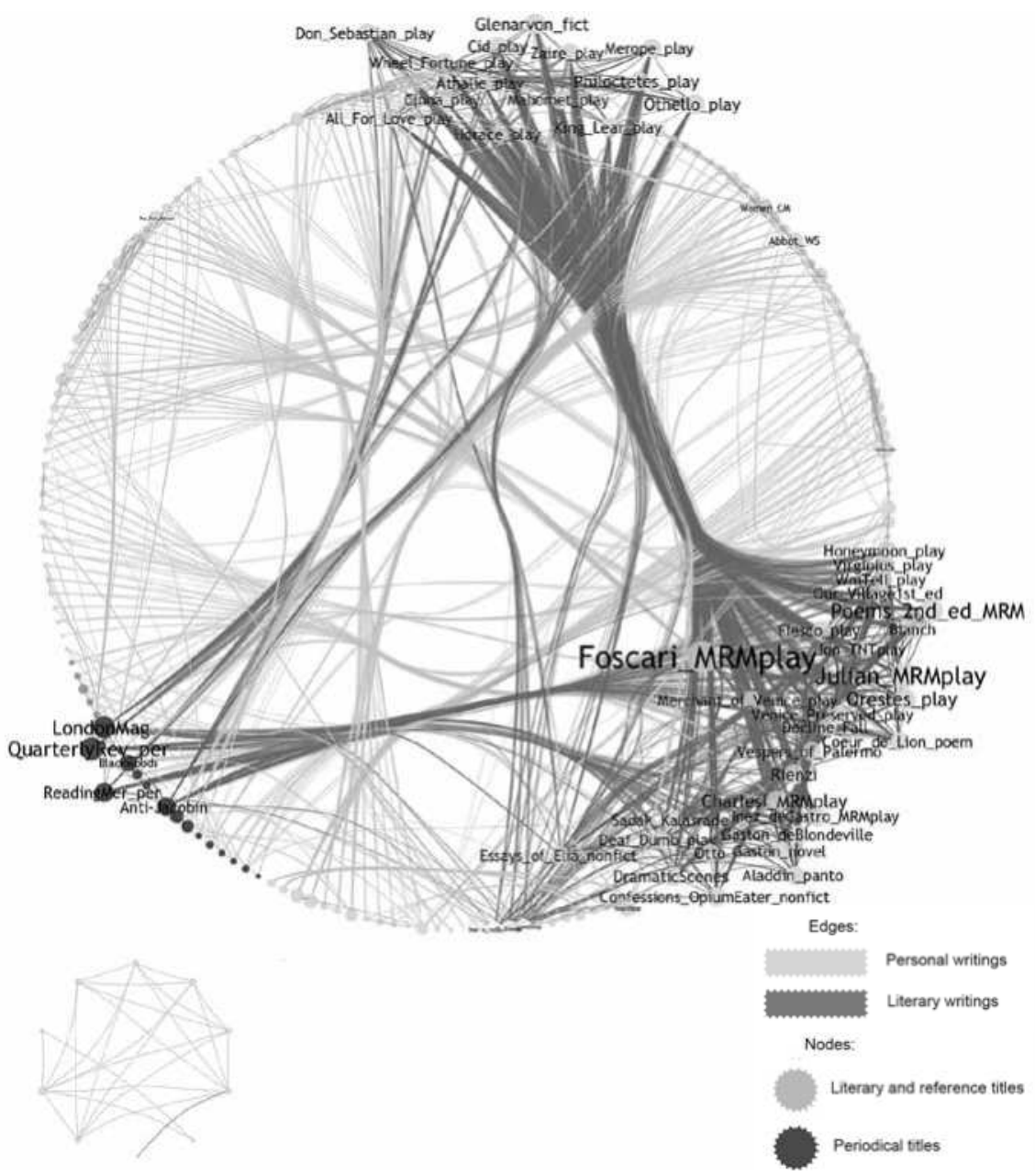

Figure 6.13: Titles of works mentioned together in Mitford's writings

of Mitford's personal literary and artistic world does she include, directly or indirectly, in her writing?

Our last graph in Figure 6.13 shows a co-citation network of titles, organized by kind. As with the fictional characters' network in Figure 6.11, the publication references currently make multiple, broken networks, with a distinct cluster of titles mentioned in one or two letters but appearing nowhere else. But a larger connected network illuminates the 196 distinct titles that Mitford has referenced in the material we have coded so far, and among these, which are emerging that she mentions the most frequently. We have organized these to distinguish periodical titles from literary titles. In the periodicals cluster, the most frequently mentioned serials so far include two that 
we might expect a late-Romantic writer to know well: The Quarterly Review and The London Magazine, but also a local publication, the Reading Mercury, emerges nearly equally in Mitford's writings. Mitford had written reviews of local theatre productions for the Reading Mercury, and that periodical's prominence in Figure 6.13 points to a regional literary and artistic marketplace that extended beyond the pull of London. By far the majority of works to which Mitford referred most frequently are plays, whether Mitford's own, plays by her contemporaries, or those from past centuries.

\section{Conclusion}

The Digital Mitford team has begun encoding a large corpus of writings in the hope of opening new areas of inquiry for nineteenth-century scholarship. In presenting visualizations drawn from the team's collective research so far, we find much in Mitford's writings to illuminate little known aspects of theater culture and periodical publishing in the 1820 s, as well as the ways in which Mitford played an influential part in shaping the literary tastes of her correspondents. Our work has begun to change the map of what we thought we knew about the nineteenth century. The networks also reveal the borders of our knowledge of nineteenth-century people, especially considering intellectual women like Miss James who have gone unmarked in the male-dominated encyclopedic databases like the ODNB. That our networks of publications and fictional personae are currently broken indicates the still formative state of our project. The 75 texts we have encoded so far are but a small fraction of Mitford's writings. In the next few years we aim to complete work on the test bed of letters, and prepare editions of Mitford's plays and the sketches of Our Village that track the variant editions of these texts to help model their transformation. We will continue to expand and study the networks of correspondence and co-citation that we have published here as we continue researching the locations of Mitford's manuscripts, and we hope to prepare dynamic, interactive views of the networks that help guide our site visitors in navigating our archive as a web linking letters and literary texts, and as a database of information about nineteenth-century people, characters, and titles.

Preparing an archive like the Digital Mitford requires building an information architecture that supports the life of a scholarly community and that is accessible to new generations of readers. Such construction requires the care of a dedicated team with a long-range perspective. By prioritizing systematic and transferrable methods of editing and text encoding, and by documenting our work carefully, we hope to engage visitors interested in Mitford as well as new contributors - students, editors, and consultants - who seek learning opportunities in working with manuscripts and learning to represent cultural artifacts in code. Our database of editions may serve to establish the place 
for Mitford that her biographer, W. J. Roberts, was so sure she had earned on the strength of her reading public, and in the process may offer a detailed view of the centrality of reading and writing in the daily life of Mitford's extensive network.

\section{Bibliography}

Addison, Catherine. 'Gender and Genre in Mary Russell Mitford's Christina'. English Studies in Africa: A Journal of the Humanities 41.2 (1998).

Beshero-Bondar, Elisa. 'Mitford vs. Hemans: Resisting the "Omnipotence of Words" in Dramatic Romance and Romantic Drama'. Literature Compass 10.5 (2013).

- 'Romancing the Pacific Isles before Byron: Music, Sex, and Death in Mitford's Christina'. ELH 76.2 (2009).

-.Women, Epic, and Transition in British Romanticism. Newark, Delaware: University of Delaware Press, 2011.

Booth, Alison. 'Revisiting the Homes and Haunts of Mary Russell Mitford'. Nineteenth-Century Contexts 30.1 (2008).

Breen, Jennifer. Women Romantics 1785-1832: Writing in Prose. London, Everyman, 1996.

Broomfield, Andrea and Sally Mitchell, eds. Prose by Victorian Women: An Anthology. New York: Routledge, 1996.

The Brownings' Correspondence: An Online Edition. Wedgestone Press, 2016. Accessed 23 August 2016. http://browningscorrespondence.com.

Burwick, Frederick. Playing to the Crowd: London Popular Theatre, 1780-1830. New York: Palgrave Macmillan, 2011.

Chorley, Henry, ed. Letters of Mary Russell Mitford, second series. 2 vols. London: Richard Bentley and son, 1872.

Coles, William Allan. The Correspondence of Mary Russell Mitford and Thomas Noon Talfourd (1821-1825). Ph.D. diss., Harvard University, 1956.

-. 'Magazine and Other Contributions by Mary Russell Mitford and Thomas Noon Talfourd'. Studies in Bibliography 12 (1959).

-. 'Mary Russell Mitford: the Inauguration of a Literary Career'. Bulletin of the John Rylands Library 40 (September 1957).

Creech, Melinda. 'Armstrong Browning Library Benefactors Day 2013 Exhibit'. Armstrong Browning Library and Museum. 16 October 2013. Accessed 24 August 2016. http://blogs.baylor.edu/armstrongbrowning/tag/mary-russell-mitford.

Deleuze, Gilles and Felix Guattari. A Thousand Plateaus: Capitalism and Schizophrenia. Translated by Brian Massumi. Minneapolis: University of Minnesota Press, 1987.

Edwards, Peter David. Idyllic Realism from Mary Russell Mitford to Hardy. Basingstoke: Macmillan, 1988.

Folsom, Ed. 'Database as Genre: The Epic Transformation of Archives', PMLA 122.5 (2007). 
Halsey, Katie. “Tell Me of Some Booklings": Mary Russell Mitford's Female Literary Networks', Women's Writing 18.1 (2011).

Helsinger, Elizabeth K. Rural Scenes and National Representation: Britain, 1815-1850. Princeton: Princeton University Press, 1997.

Hoagwood, Terence and Kathryn Ledbetter. 'Colour'd Shadows': Contexts in Publishing, Printing, and Reading Nineteenth-Century British Women Writers. New York: Palgrave Macmillan, 2005.

L'Estrange, A. G., ed. The Friendships of Mary Russell Mitford, as Recorded in Letters from her Literary Correspondents. 2 vols. London: Hurst and Blackett, 1882.

-. ed. The Life of Mary Russell Mitford, Related in a Selection from her Letters to her Friends. 3 vols. London: Richard Bentley, 1870.

-. The Literary Life of the Rev. William Harness. London: Hurst and Blackett, 1871.

Lynch, Deidre. 'Homes and Haunts: Austen's and Mitford's English Idylls', PMLA 115.5 (2000).

McDonagh, Josephine. 'Rethinking Provincialism in Mid-Nineteenth-Century Fiction: Our Village to Villette'. Victorian Studies 55.3 (2013).

McGann, Jerome J., ed. The New Oxford Book of Romantic Period Verse. Oxford: Oxford University Press, 1993.

Mitford, Mary Russell to William Elford, 3 January 1810, Reading Central Library.

—. to George Mitford, 4 April 1810, qB/TU/MIT, Vol. 1, ff. 43, Reading Central Library.

-. to Richard Benyon, June 1822, D/EZ 25, Berkshire Record Office.

—. to S. Hamilton, 9 April 1823, qB/TU/MIT, Vol. 4, ff. 468, Reading Central Library.

—. to Thomas Noon Talfourd, undated/apparently 1828, English MS 665 (R69047), 35, John Rylands Library.

—. 'The Two Magpies', The Juvenile Keepsake, ed. Thomas Roscoe. London: Hurst, Chance \& Co., 1830.

Moretti, Franco. Graphs, Maps, Trees. London: Verso Books, 2005.

-. Distant Reading. London: Verso Books, 2013.

Morrison, Kevin A. 'Foregrounding Nationalism: Mary Russell Mitford's Our Village and the Effects of Publication Context'. European Romantic Review 19.3 (2008).

-. 'Modulating Narrative Voice: Mary Russell Mitford's Sketches of Rural Character'. Women's Writing 22.4 (2015).

Pietropoli, Cecilia. 'The Tale of the Two Foscaris from the Chronicles to the Historical Drama: Mary Mitford's Foscari and Lord Byron's The Two Foscari, British Romanticism and Italian Literature: Translating, Reviewing, Rewriting, ed. Laura Bandiera and Diego Saglia. Amsterdam: Rodopi, 2005.

Price, Kenneth M. 'Edition, Project, Database, Archive, Thematic Research Collection: What's in a Name?' Digital Humanities Quarterly 3:3 (2009).

Raisanen, Elizabeth. "'Speech / Is Your Fit Weapon”: Mary Russell Mitford's Rienzi and the Gendering of Speech Acts', European Romantic Review 22.2 (2011). 
Roberts, J. W. Mary Russell Mitford: The Tragedy of a Blue Stocking. London: A. Melrose, 1913.

Robertson, Fiona, ed. Women's Writing 1778-1838: An Anthology. Oxford: Oxford University Press, 2001.

Saglia, Diego. 'Mediterranean Unrest: 1820s Verse Tragedies and Revolutions in the South'. Romanticism 11.1 (2005).

-. Poetic Castles in Spain: British Romanticism and Figurations of Iberia. Amsterdam: Rodopi, 2000.

-. 'Public and Private in Women's Romantic Poetry: Spaces, Gender, Genre in Mary Russell Mitford's Blanch'. Women's Writing 5.3 (1998).

—. 'When Mitford Met Baillie: Theatre, Sociability and the Networks of Women's Romantic Drama,' Women's Romantic Theatre and Drama: History, Agency, and Performativity, ed. Lilla Maria Crisafulli and Keir Elam. Farnham, England: Ashgate, 2010.

Swartz, Richard G. 'Wordsworth, Copyright, and the Commodities of Genius'. Modern Philology 89:4 (1992).

Text Encoding Initiative. TEI: Text Encoding Initiative. Accessed 15 June 2016. http://tei-c.org/index.xml.

Watson, Vera. Mary Russell Mitford. London: Evans Brothers Limited, 1949. 


\title{
The Citational Network of Tighe, Porter, Barbauld, Lefanu, Morgan, and Hemans
}

\author{
Harriet Kramer Linkin
}

In making the case for the recovery of Mary Tighe in the 1990s scholars often pointed to the adverse impact John Keats' rejection of Tighe had on her literary reputation for most of the twentieth century as the canon of the big five or six British Romantic-era male poets came into being. ${ }^{1}$ Despite the ongoing but unacknowledged influence Tighe's posthumous 1811 Psyche, with Other Pooms exerted on Keats in 1819 and 1820 as he composed and published 'Ode to Psyche', 'The Eve of St. Agnes', and 'Lamia', and worked on transforming 'Hyperion' into 'The Fall of Hyperion', his 31 December 1818 comment on Tighe in a letter to his brother and sister-in-law came to be seen as representative of the canonical male poets' reception of her work: 'Tighe and Beattie once delighted me - now I see through them and can find nothing in them - or weakness.' ${ }^{2}$ Rather than speaking for the British Romantic community, however, Keats' comment more directly spoke to his desire to push his poetic agenda forward after the negative reviews of Endymion - a poem that also reflects Tighe's influence - so that he might 'be among the English Poets after my death'. ${ }^{3}$ It is one of the curiosities of twentiethcentury literary history that Keats' personally motivated comment came to bear

${ }^{1}$ See Marlon Ross, The Contours of Masculine Desire: Romanticism and the Rise of Women's Poetry (New York: Oxford University Press, 1989); Greg Kucich, 'Gender Crossings: Keats and Tighe', Keats-Shelley Journal, 44 (1995), pp. 29-39; and Harriet Kramer Linkin, 'Recuperating Romanticism in Mary Tighe's Psyche', in Romanticism and Women Poets: Opening the Doors of Reception, ed. Harriet Kramer Linkin and Stephen C. Behrendt (Lexington: University Press of Kentucky, 1999), pp. 144-62.

2 The Letters of John Keats, ed. Hyder Edward Rollins, 2 vols. (Cambridge: Harvard University Press, 1958), 2: p. 18.

${ }^{3}$ Letter to George and Georgiana Keats, c. 25 October 1818, Rollins, 1: p. 394. Also see 8 October 1818 letter to James Augustus Hessey, in which Keats says with regard to 
such weight and appear to voice a communal response to Tighe, given the plenitude of positive assessments her work received from nineteenth-century readers, writers, and critics in direct or indirect homages. ${ }^{4}$ This essay looks at some of the contemporary women writers who invoked Tighe in their works by name, quotation, or epigraph - Anna Maria Porter, Anna Letitia Barbauld, Alicia Lefanu, Lady Morgan, and Felicia Hemans - to consider what those invocations suggest about lines of affiliation, the construction of aesthetic communities, and attempts to shape or forecast reception. I argue that these Romantic-era woman writers create a citational network through the figure and work of Mary Tighe, to call attention to her significance and to establish their own histories of influence and reception.

Such citational practices produce a more expansive version of what Gerard Genette designates the 'epigraph effect' in Paratexts, affording opportunities for writers to signal their place in a cultural tradition, to acknowledge or choose their peers and predecessors, and to proleptically instantiate their consecration in a particular literary pantheon. ${ }^{5}$ Genette dates the first instance of an epigraph at the head of a work to $1632,{ }^{6}$ but observes that the habitual use of epigraphs to mark each chapter of a prose narrative really begins with the gothic novels of the 1790s and the work of Ann Radcliffe, who, in Emma Clery's view, daringly positions herself in a particular line of literary succession (Shakespeare, Milton, Thomson, Collins, Gray, et al.) through the careful associations she builds via her epigraphs. ${ }^{7}$ Clery characterizes Radcliffe as a literary bandit who employs epigraphs and quotations to enact a form of 'textual kidnapping' (53): 'she creates an authorial persona of the noble outsider in a fallen world of commodified literary production through her display of cultivated sensibility, her dramatized admiration for her 'kidnapped' texts from Shakespeare, Milton and company' (54). Radcliffe not only positions herself in a line of succession, she casts herself as the nominator of additions to the line by citing the works of a few female contemporaries, namely Charlotte Smith, Hannah More, and Anna Seward; thus, as Clery

Endymion, 'I was never afraid of failure; for I would sooner fail than not be among the greatest' (Rollins, 1: p. 374).

${ }^{4}$ As Arnold Markley observed, that number included canonical figures like Lord Byron, Percy Bysshe Shelley, and Mary Shelley. See his essay 'Curious Transformations: Cupid, Psyche, and Apuleius in the Shelleys' Works', The Keats-Shelley Review, 17 (2003), pp. 120-35. For a larger list see my essay on 'Mary Tighe and Literary History: the Making of a Critical Reputation', Literature Compass, 7: 7 (July 2010), pp. 564-76.

${ }_{5}^{5}$ Gerard Genette, Paratexts: Thresholds of Interpretation, trans. Jane E. Lewin (Lincoln: University of Nebraska Press, 1997), p. 160.

${ }^{6}$ Genette initially cites La Rochefoucauld's 1678 edition of Maximes, but footnotes Bardin's 1632 Lycée du sieur Bardin (p. 145).

7 Emma J. Clery, Women's Gothic: From Clara Reeve to Mary Shelley (Devon: Northcote House, 2000). 
argues, 'she succeeded in bolstering her credentials as a writer to be taken seriously, with powers that aspired towards the standards set by the great national poets. To read a Radcliffe novel was not simply to idle away a few hours on a silly story. Her most celebrated works were freighted with a massive accumulation of cultural capital' (57). Unlike the anxious and often concealed influences and intentions of the writers Harold Bloom mapped in his analyses of literary history, the overt and intentional invocations of Smith, More, and Seward by Radcliffe, or Tighe by Porter, Barbauld, Lefanu, Morgan, and Hemans, establish what Mary Orr and others identify as a mode of 'positive influence' that enables and enlarges successors: by citing Tighe they enhance her cultural capital and their own. ${ }^{8}$ As Ellen Moers demonstrated in her landmark discussion of 'performing heroinism' in Literary Women, nineteenth-century women writers built networks of affiliation through shared citation; Moers traced one such network through references to Germaine de Staël's Corinne, a text and model of the woman genius that acquired mythic status for George Eliot, Hemans, Maria Jane Jewsbury, Elizabeth Barrett Browning, George Sand, Charlotte Brontë, Kate Chopin, and more.' Some of the references Moers located expressed the anxiety of authorship Sandra Gilbert and Susan Gubar subsequently diagnosed in The Madwoman in the Attic, their brilliant rejoinder to Bloom. ${ }^{10}$ But most of the references Moers uncovered underscored the empowering psychology of affiliation, connection, and community that figures so prominently in twenty-first-century critical conceptions of Romantic-era sociability: the interactive, conversable worlds of salons, coteries, literary circles, and social networks that have come into sharper focus through the work of Gillian Russell, Clara Tuite, Jeffrey Cox, Michelle Levy, Stephen Behrendt, Susan Wolfson, Jon Mee, Susanne Schmid, Amy Prendergast, and many others. ${ }^{11}$ Like the actual coteries that connected

${ }^{8}$ Mary Orr, Intertextuality: Debates and Contexts (Cambridge: Polity, 2003), p. 84. Also see Michael Baxandall, Patterns of Intention: On the Historical Explanation of Pictures (New Haven: Yale University Press, 1985), pp. 58-9 and Jay Clayton and Eric Rothstein, Influence and Intertextuality in Literary History (Madison: University of Wisconsin Press, 1991), pp. 6-7. For Harold Bloom see The Anxiety of Influence: A Theory of Poetry (New York: Oxford University Press, 1973) or A Map of Misreading (New York: Oxford University Press, 1975).

9 Ellen Moers, Literary Women: The Great Writers (New York: Doubleday, 1976), pp. 173-210. See Kari Lokke's Tracing Women's Romanticism: Gender, History and Transcendence (New York: Routledge, 2004) for a book-length treatment of Corinne and its impact on Mary Shelley, Bettine von Arnim, George Sand, and Isaak Dineson.

${ }^{10}$ Sandra Gilbert and Susan Gubar, The Madwoman in the Attic: The Woman Writer and the Nineteenth-Century Literary Imagination (New Haven: Yale University Press, 1979).

${ }^{11}$ Gillian Russell and Clara Tuite, Romantic Sociability: Social Networks and Literary Culture in Britain, 1770-1840 (Cambridge: Cambridge University Press, 2002), Jeffrey Cox, Poetry and Politics in the Cockney School: Keats, Shelley, Hunt and Their Circle 
so many Romantic-era writers - including Tighe - the women writers who invoke Tighe as a posthumous presence in their poetry and fiction constitute a community or even imaginary salon engaged in reading her work and life to see or suggest how it amplifies their own works and lives.

I begin with Anna Maria Porter, whose only volume of poetry, the 1811 Ballad Romances, and Other Poems, offers a tribute to Tighe that makes a surprising connection between Corinne and Psyche: 'Lines written after reading the "Corinne" of Madame de Stael, and the "Psyche" of the late Mrs. Henry Tighe'. Although Porter was better known as a prolific novelist, and, with her older sister Jane Porter, acknowledged during the Romantic era as 'one of the founders of the modern historic romance, ${ }^{12}$ she published numerous poems in literary magazines, annuals, and miscellanies throughout the 1790s and first decades of the 1800s. Not only did her work appear in The Lady's Magazine, The Universal Magazine, The Poetical Register, The Literary Miscellany, The Chaplet, The Ladies Monthly Museum, Fraser's Magazine, La Belle Assemblée and elsewhere (including her own novels), she was a regular contributor to 'The Parnassian Garland' section of The Monthly Visitor (1797-1804), which printed more than 40 of her lyrics under various signatures ('Anna', 'Anna Maria', 'Anna Maria Porter', 'A.', and 'A. M.'), as well as poems addressed to her. ${ }^{13}$ Some of

(Cambridge: Cambridge University Press, 2004), Michelle Levy, Family Authorship and Romantic Print Culture (New York: Palgrave Macmillan, 2008), Stephen C. Behrendt, British Women Poets and the Romantic Writing Community (Baltimore: Johns Hopkins University Press, 2009), Susan J. Wolfson, Romantic Interactions: Social Being and the Turns of Literary Action (Baltimore: Johns Hopkins University Press, 2010), Jon Mee, Conversable Worlds (Oxford: Oxford University Press, 2011), Susanne Schmid, British Literary Salons of the Late Eighteenth and Early Nineteenth Centuries (Palgrave Macmillan, 2013), and Amy Prendergast, Literary Salons Across Britain and Ireland in the Long Eighteenth Century (New York: Palgrave Macmillan, 2015).

${ }^{12} \mathrm{H}$, 'Contemporary Poets and Writers of Fiction. No. XII. - Miss Anna Maria Porter', La Belle Assemblee, or Court and Fashionable Magazine, new series 4: 22 (October 1826), p. 144. The 'Illustrative Memoir of Miss Jane Porter' in The Atheneum, new series 3: 8 (15 July 1825) similarly remarks 'It is not too much to say, that, of the superior historical romance, Miss [Jane] Porter is the founder' (p. 290). As Devoney Looser notes, scholars recognize that the genre of historical fiction began in the 1760s, long before Walter Scott's Waverley novels as once thought, which Jane Porter's celebrated novels Thaddeus of Warsaw (1803) and The Scottish Chiefs (1810) predate, as does Anna Maria Porter's The Hungarian Brothers (1807). See Looser's 'The Porter Sisters, Women's Writing, and Historical Fiction', in The History of British Women's Writing, 1750-1830, ed. Jacqueline M. Labbe (Hampshire: Palgrave Macmillan, 2010), pp. 233-53.

${ }^{13}$ The first 'Parnassian Garland' collection, for instance, contained sonnets by R. A. Davenport and Woodville (probably Samuel Egerton Brydges) addressed to 'Miss Anna Maria Porter'. See Marianne Van Remoortel, Lives of the Sonnet, 1787-1895: Genre, Gender, and Criticism (Farnham: Ashgate, 2011) for some discussion of the Monthly Visitor (p. 74). 
her 'Parnassian Garland' lyrics engaged in a Della Cruscan-style conversation with other poets, including occasional contributor and family friend Mary Robinson, under her 'Laura Maria' avatar, to whom Porter dedicated at least two poems. In the deliciously barbed and competitive sixteen-line lyric 'The Rose. To Laura' (8 July 1800), 'Anna Maria' addresses her lines to a rose she intends to send to Laura to compliment and complement Laura's bosom, which 'numbers have languished in vain to adorn' (line 4), but slyly warns the rose to conceal its thorn: 'At rest on her bosom thy beauties revealing, / Ah! ne'er let it feel that thy hidest a thorn' (lines 15-16). ${ }^{14}$ The following April, four months after Robinson's death, 'Anna' offers a forty-eight-line 'Elegy to the Memory of Mrs. Robinson', which feelingly declares 'Ah! Laura! had I but thy tuneful lyre, / The matchless beauties of thy verse to sing; / ... / Then would I censure the base world, so prone / To doubt thy heart, whose worth they could not know' (lines 9-14). ${ }^{15}$ Though couched in the familiar stance of the humble elegist, Porter takes up her own tuneful lyre to sing the beauties of her predecessor's verse, and therein not only matches but in some ways surpasses it through her now peerless act of recognition..$^{16}$

Tighe knew Porter's work as a poet, as well as several of the Porter sisters' novels. ${ }^{17}$ She used a carefully edited version of nine of the first fourteen lines of Porter's 1797 'Parnassian Garland' lyric 'Written After Having Seen a

${ }_{14}$ The Monthly Visitor, 10 (July 1800), p. 301. This poem may or may not have been precipitated by the two poems Mary Robinson published for the Porter sisters in the 16 June 1800 Morning Post and Gazetteer, 'To Miss Porter, in the Character of a Nun' (for Jane Porter) and 'To Miss Maria Porter, as Roxalana', which follow a series of poems by Jane Porter. Daniel Robinson notes that the Porter sisters 'attended a much publicized masquerade; Robinson's poems to each are based on the costumes the sisters likely wore' (The Works of Mary Robinson, ed. William D. Brewer, 8 vols. [London: Pickering \& Chatto, 2009], 2: p. 433). Robinson invited the Porter sisters and their mother to visit in a 27 August 1800 letter to Jane Porter which famously stated 'If I do not enter into the true spirit of Friendship for my own Sex, it is because I have almost universally found that Sex unkind and hostile towards me .... The women whom I have most admired, have been the least prone to condemn, while they have been themselves the most blameless. - Of this distinguished class I consider you' (Mary Robinson: Selected Poems, ed. Judith Pascoe [Peterborough: Broadview, 2000], p. 371).

15 The Monthly Visitor, 12 (April 1801), pp. 410-11.

${ }^{16}$ See Jacqueline Labbe's 'Re-membering: Memory, Posterity, and the Memorial Poem', in Memory and Memorials, 1789-1914: Literary and Cultural Perspectives, ed. Matthew Campbell, Jacqueline M. Labbe, and Sally Shuttleworth (London: Routledge, 2000), pp. 132-46 for discussion of how women poets employ elegiac recognition to consecrate their taste as survivors.

${ }_{17}$ Tighe's reading journal entry for 17 March 1809 declares The Hungarian Brothers 'very inferior to Thaddeus of Warsaw - stupid'. On 1 June 1809 she notes 'Ker Porter's travels in Russia unmercifully quizzed' in the Edinburgh Review. See MS 4804, National Library of Ireland, Dublin. 
Lovely But Miserable Girl' ${ }^{18}$ as an epigraph for the eighth chapter of her 1803 manuscript novel Selena, in which Selena Miltern meets the tragic character Angela Harley:

Slight was her form, and graceful o'er her neck Sicklied with primrose tint, her jetty locks Fell rich but rudely - whilst her mournful eyes Beamed thro' a watry lustre, she was formed In Nature's kindness - and tho' the rose No longer melted in her cheek, nor blushed With deeper brilliance on her lip yet still Unnumbered graces decked her, and looked forth At every feature - the wreck of better days. ${ }^{19}$

Tighe omitted all of Porter's references to the impoverished or questionable status of the 'miserable girl', notably lines one through five -

Slight was her form, and graceful; as she pass'd, Mine eye fell on her, and with quick surprize Recoil'd; for the few garments that she wore, Blew, torn on the cold wind, and scarcely cloth'd The beauties they so sullied: o'er her neck (my emphasis)

- and line thirteen: 'At every feature - thro' her rags there shone / The wreck of better days' (my emphasis). But Tighe's citation of the poem serves a crucial function in setting up Angela's story and Selena's compassionate role in that story. Discerning readers familiar with Porter's fifty-six-line lyric would know that it goes on, at just this point, to speak in the first-person voice of a persona with a sympathetic 'female eye' (line 49) who recognizes the girl as a prostitute and regrets her fall from domesticity into vice but ultimately condemns the men who seduced her, a stance comparable to the one 'Anna' adopts in censuring the world that doubted 'Laura' in 'An Elegy to the Memory of Mrs. Robinson':

18 'Written After Having Seen a Lovely But Miserable Girl' was first published in The Parnassian Garland. Forming the Poetry of The Monthly Visitor, Vol. I and II (London, 1797), pp. 116-7, reprinted in The Poetical Register, and Repository of Fugitive Poetry, for 1801 (London: Rivington, 1801), pp. 259-60, The Literary Miscellany; Or, Selections \& Extracts: Classical and Scientific; with Originals, in Prose and Verse, vol. 5 (London: Nicholson, 1804), pp. 58-9 and elsewhere.

${ }_{19}$ Mary Tighe, Selena by Mary Tighe: A Scholarly Edition, ed. Harriet Kramer Linkin (Farnham: Ashgate, 2012), p. 64. 
'Unhappy girl! a female eye shall shed

Those tears for thee, which ought in drops of blood

To fall from thy seducer. Shame, O world!

That man thus privileged to ruin souls,

Shall rove about undaunted; whilst the wretch

Whom he hath made, must either die unseen,

Or plunge in deeper guilt, and fall for ever!' (lines 49-55)

In Selena, Angela Harley is also a 'lovely but miserable girl' because she has been seduced but still pines for the seducer who abandoned her, a man Selena eventually exposes to save the broken heart and foundering reputation of another one of his prospective victims, Lady Emily Trevallyn. By prefacing Selena's first sight of Angela with Porter's lyric, Tighe makes potent use of the epigraph effect to establish the moral framework of her characters' relationships and to condition the terms of her readers' judgments. Tellingly, this chapter prints the first of the eleven Tighe lyrics Selena includes shortly after the epigraph, 'Lord of Hearts benignly callous' $(65-6),{ }^{20}$ a poem the novel attributes to Lady Emily, who asks 'Insensibility' for respite from the agony of delusive passion and seductive love. Thus Tighe's lyric speaks to Porter's lyric and furthers the work the chapter's epigraph seeks to effect in establishing a line of affiliation and forecasting an ethical position for her characters and her readers.

Whether or not Porter knew that Tighe found 'Written After Having Seen a Lovely But Miserable Girl' an instrumental citation for Selena, Porter's "Lines written after reading the "Corinne" of Madame de Stael, and the "Psyche" of the late Mrs. Henry Tighe' addresses and expands their mutual affinity by positioning both Tighe and Staël as inspiring models who evince the same spirit of genius and voice the same theme, despite their apparent differences:

Magic omnipotent! resistless power

Of Genius, seraph-lipp'd! how doth thy force

Seize the most fixed soul, and bear it on

Thro' every change of passion, pain, or joy! -

How mighty is thy sway! how wide its range!

How varied, e'en in uniform design! -

Lo! now thro' different lips, thy voice inspired,

Speaks to my heart; transports, depresses, fills! -

${ }^{20}$ Formally titled 'Verses Written for Emily 1799' in Tighe's definitive 1805 collection Verses Transcribed for H. T., ed. Harriet Kramer Linkin (Romantic Circles, 2015), rc.umd. edu/editions/tighe_verses. 
In rapt amazement lost, the same fond theme Wondering I hear, and mark how different each! Methinks from deep shades, swells th' Eolian lyre; While from some twilight grove, soft Philomel Warbles her rival song. (lines $1-13)^{21}$

Whereas the glorious improvisations of Staël's Corinne ring and moan like the wild notes of an aolian harp (lines 14-34), the equally rapturous but gentler modulations of Psyche's story soar and descend like a nightingale's melody (lines 36-68). In a masterful mediation Porter not only insists on connecting these two seemingly disparate styles and the romanticized positions of their subjects and authors, she critiques what she sees as the false division a poet like Samuel Taylor Coleridge posits for the feminine mystique in 'The Eolian Harp', which she deliberately invokes towards the end of the poem - 'May all blest Araby's innumerous sweets / Hang on the breeze that sweeps them into sound!' (76-7) - or, even more importantly, the dichotomous females of 'Kubla Khan'.22 For Porter the woman wailing for her demon-lover and the damsel with a dulcimer sing the same song, ever empowering, and never to be forgotten, as she declares of Tighe, her 'Nightingale of Rossana' (line 51): 'How happy they, who 'mid thy native shades / Roved near thee ever ... / ... / ... whilst we / (Thro' deep empowering woods, at distance far,) / But heard thee once, tho' never to forget!' (lines 60-8). ${ }^{23}$ If Coleridge laments his inability to revive enough of the Abyssinian maid's symphony so that he could build an epic pleasure-dome that rivals Kubla Khan's, Porter suggests that her empathetic reading of Corinne and Psyche enables her to serve as the next instrument of the 'seraph-lipped' power of genius, via Ballad Romances, and Other Poems, the readiest object of the benediction that concludes the poem: 'May breath of angels aid the blissful gales, / And while thou warblest love, awake the soul / To thought of Love's best world, the world of Heaven!' (lines 78-80).

As the only named peers in Ballad Romances, and Other Poems, ${ }^{24}$ Tighe

${ }^{21}$ Anna Maria Porter, Ballad Romances, and Other Poems (London: Longman, 1811), pp. 123-7.

22 Although 'Kubla Khan' was not published until 1816 in Christabel; Kubla Khan: A Vision; The Pains of Sleep (London: John Murray, 1816), Porter could have had access to the manuscript (via Robinson, at the very least, whose response to the poem 'Mrs. Robinson to the Poet Coleridge' was published in her posthumous Memoirs of the Late Mrs. Robinson, Written by Herself, 4 vols. [London: Phillips, 1801], 4: pp. 145-9).

${ }_{23}$ These lines suggest that Porter may have had the opportunity to hear Tighe read Psyche, perhaps while Tighe was in England in 1804-5, seeking medical treatment for her tuberculosis and preparing the manuscript of Psyche for private publication.

${ }^{24}$ In the prefatory comment to 'A War-Song. Written in the Summer of 1808' Porter notes 
and Staël may appear at first glance as unlikely precursors for a volume that presents five romance ballads in its first half (pages 3-76), followed by thirty-eight miscellaneous poems in the second half (pages 79-196), including Porter's 'Lines' on reading Corinne and Psyche. While the gothic sensibilities of 'Eugene', 'Lord Malcolm', 'The Knight of Malta', 'The Maid of Erin', and 'The Prince of the Lake' manifest greater affinity with similar ballads by Radcliffe, Matthew Lewis, or Anne Bannerman, Porter's romances read as lyric national tales or metrical legends, specifically located in England, Scotland, Spain, and Ireland. Like Staël's Corinne, Porter creates - or recreates - national histories in a minstrel tradition; like Tighe in Psyche, she mythologizes romance and desire. In pointing to these two precursors as models, Porter seeks to position herself in a particular romance tradition even as she signals the larger ambition driving her project. She not only wants to make a bid for the laurel that crowned Staell's Corinne at the capitol, or to achieve the extraordinary acclaim Tighe received as the author of Psyche long before its posthumous publication in 1811. She intends to fulfill the 'fond request' (line 10) she made of the muse in her first 'Parnassian Garland' poem, the 1797 'Address to Poesy', which asks to be the voice of imagination over fancy: 'I ask to catch thy thought-inspiring breath, / To warble trancing lays resembling thine, / The soul of love to melt along my line, / Sigh in each word and tremble thro' the song, / I seek the power to touch the gentle heart, / With bleeding sympathy and kind concern' (lines 11-16, pages 3-5). By 1811 Porter had already published seven works of fiction, including her most famous work, The Hungarian Brothers (1807), and the very well-received Don Sebastian (1809); she and Jane Porter were beginning to acquire significant status as groundbreaking novelists for blending romance with reality, notably using 'sensitive male warrior-protagonists whose military careers and domestic lives were closely intertwined' (Looser 234). ${ }^{25}$ Ballad Romances, and Other Poems meant to secure even greater success in the prestige genre of poetry, following hard upon the publication of Tighe's Psyche, with Other Poems (Longman published Ballad Romances two months after Psyche). ${ }^{26}$ It was not to be.

that she gave a manuscript of the poem to Sir Thomas Dyer (p. 120); she also includes what is most likely a poem for her sister, 'Sonnet on Jane' (p. 155). Looser observes that 'the Porters do not often credit (privately or publicly) male or female predecessors with having inspired their own work - the very thing that they claimed was happening to them' (p. 245).

${ }^{25}$ Also see Thomas McLean, 'Nobody's Argument: Jane Porter and the Historical Novel', Journal for Early Modern Cultural Studies, 7: 2 (2007), pp. 88-103.

${ }^{26}$ According to the Records of the Longman Group, Longman published the quarto edition of Psyche, with Other Poems in May 2011 (followed by the octavo edition in August 1811) and published Porter's Ballad Romances, and Other Poems in July 2011 (MS 1393, Longman Archives, Impression Book 4, University of Reading Library, Reading). 
Eight periodicals reviewed Ballad Romances, and Other Poems between 1811 and $1813 .{ }^{27}$ The first, the Poetical Register of 1811, praised the ballad romances as 'beautiful', commended the 'glowing fancy' of the Spenserian allegory 'Youth', and felt 'The epistle from Yarico to Inkle leaves far behind every other poem which we have seen on the same subject', but less generously concluded 'The remaining pieces in the volume are much above mediocrity' (p. 614). ${ }^{28} \mathrm{~A}$ far less generous and more substantial review appeared in the Edinburgh Monthly Magazine and Review, which coldly noted that an author may be skilled in one mode but not another, and declared Porter's 'volume so much inferior to the other writings of the ingenious author, that had it been published anonymously, no one, we are positive, would have ever thought of ascribing it to the pen of Miss Maria Porter' (p. 200). Objecting to the 'extravagance, exaggeration, and incongruity' of the ballads, the reviewer pointedly belittled Porter's ambition: 'it was an ambition natural and excusable enough in a lady, who has deservedly attained so much fame in the department of romance, to seek also distinction in the poetical' (p. 201). Damning with barely faint praise, the review ranked Porter's poems so far below 'mediocrity' that 'her praise must therefore be entirely negative; many of her pieces contain pretty couplets and good stanzas; but the most that can be said of them as a whole is, that they are not absolutely bad' (p. 201). The British Critic and Critical Review were equally blunt: while the one stated 'These poems are a little above mediocrity, but will not obtain Miss Porter any very enduring reputation' (p. 301), the other found 'little which deserves commendation. ... We can only place her in the second class of the lesser poets of the day' (p. 164). The Eclectic Review tempered its general disdain for the abundance of poetry in the marketplace that displays 'presumption and defect' by citing Porter's compositions as 'not remarkable for elevation of thought, or terseness of expression; but she usually writes with elegance, and is sometimes peculiarly successful in pourtraying the gentler emotions of the heart' (p. 430); they added insult to injury by summarily dismissing the 'dulness' of the ballad romances in the final sentence (p. 432). The European Review managed to say nothing at all about the volume beyond hoping to

${ }^{27}$ See William Ward, Literary Reviews in British Periodicals, 1798-1820, 2 vols. (New York: Garland, 1972), 2: p. 447, who lists the following eight reviews: British Critic, 40 (September 1812), p. 301; Critical Review, 1, series 4 (February 1812), pp. 164-5; Eclectic Review, 8 (April 1812), pp. 430-2; Edinburgh Monthly Magazine and Review (Scotish Review), 1 (September 1812), pp. 133-41; European Magazine, 64 (December 1813), p. 521; Gentleman's Magazine, 83: 2 (December 1813), p. 576; Monthly Review ,67 (March 1812), pp. 325-6; and Poetical Register, 8 (1811), p. 614.

${ }^{28}$ Ironically, this issue of the Poetical Register also reviewed Tighe's Psyche, with Other Poems, noting that it was now in its fourth edition, and the Tighe was fully deserving of 'the general applause which the merit of her work has gained for her' (p. 604). 
'procure it friends' (p. 521), a hope echoed by the ever congenial Gentleman's Magazine, which recommended the volume for 'the easy simplicity of its verses, and their perfectly moral tendency' (p. 576) and sought to cast positive attention on 'Eugene' as well as 'Youth'.

The most interesting review appeared in the Monthly Review, penned without attribution by family friend Anna Barbauld, who critiqued what she saw as the volume's shortcomings, the ballads, but recognized and strengthened the affiliations and alignments Porter tried to establish by singling out the homage to Staël and Tighe for praise, using more than half of the review to extract 'a part of the apostrophe to the authoress of Psyche':

Miss Porter's Ballads display less invention than her other poems; and in 'the knight of Malta', which is the best of them, she hazards the following description of a 'green and yellow melancholy':

'His cheek was once like the orange red, But now like the olive pale.

And his heart that erst with pity bled,

Now heaves through pitiless mail'. -

Yet this volume contains much that is elegant and pleasing; the ingenious allegory of 'Youth' has many beautiful lines; the 'Address to a Regiment going on Foreign Service' is both spirited and pathetic; while the 'Lines written after reading the "Corinne" of Madame de Stael, and the "Psyche" of the late Mrs. Henry Tighe', are fraught with so much taste, feeling, and generous enthusiasm that we should be glad to extract them at length. We shall, however, present our readers with a part of the apostrophe to the authoress of Psyche. (p. 325)

Barbauld then quoted lines 36-55 of 'Lines written after reading the "Corinne" of Madame de Stael and the "Psyche" of the late Mrs Henry Tighe', ${ }^{29}$ nearly two thirds of the tributary lines to Tighe, and therein implicitly suggested a similarity between Tighe's poetry and Porter's:

Ah, sounds divine! whence flow ye? from yon copse,

Steal on the depth of night, melodious sighs

From Love's own bosom heaved: the warbled lay,

First softly wooing, then lamenting sad,

Now trembling with delight, with hope, half bliss,

With dear persuasion of partaken joy,

${ }^{29}$ Barbauld inadvertently omits line 45, 'With gentler murmur glide the silver streams'. 
Soars and descends by turns: all nature melts

To softer charm, beneath its influence pure (lines 36-43)

By not only naming Porter's poem but also including Porter's lines on Tighe, Barbauld enhanced the citational impact of Porter's words, using her role as an anonymous reviewer to advance or at least advocate the existence of a Tighe-Porter node. Like Porter, Barbauld may or may not have known that Tighe cited her work in Selena, which quotes the first four lines of Barbauld's 1773 'Song I' ('Come here fond youth, whoe'er thou be') to describe Selena's beloved Sidney Dallamore (p. 213), but these intersecting citations reveal a network of affiliations among all three.

Porter went on to publish another ten works of fiction after Ballad Romances, and Other Poems (including two with Jane Porter); she frequently interpolated her verse in the novels, and continued to contribute poems to literary magazines and annuals (especially during the 1820s), but she never published another volume of poetry. In 1819 a biographical memoir in the New British Lady's Magazine praised her accomplishments as a novelist but only remarked, in the penultimate paragraph, that 'it should be also mentioned, that her poetical talents are of an order far above mediocrity. In earlier life she devoted much of her attention to the Muses; but, of late years, it is only in a few occasional stanzas, here and there scattered over the pages of her novels, that we meet with the tender or the lofty rhyme, the offspring of momentary inspiration'. ${ }^{30}$ The Atheneum echoed that sentiment and phrasing in its 1825 'Illustrative Memoir' of Jane Porter that mentioned Anna Maria Porter's early promise as a poet: "This lady may be said, like Pope, to have "lisped in numbers". Of late years, however, with the exception of one little volume, it is only in a few occasional stanzas, here and there scattered over the pages of her romances, that we meet with the tender or the lofty rhyme - the produce, apparently, of momentary inspiration' (p. 289). Five years later the Atheneum published a sketch of Anna Maria Porter which offered a detailed discussion of all her novels but relegated her poetry to juvenilia, 'found in her volume of Ballads and Lyrics'. ${ }^{31}$ When Porter died in 1832, her obituaries rightly emphasized her major contributions to narrative literature, but rarely addressed her work as a poet beyond listing the title of Ballad Romances, and Other Poems, though the North American Magazine did state that 'Miss A. M. Porter was a sweet poetess', ${ }^{32}$ and the Annual Biography and Obituary piece now known to be

\footnotetext{
30 'Biographical Memoir of Miss Anna Maria Porter', New British Lady's Magazine, 3 (July 1819), p. 5.

31 'Miss Anna Maria Porter', The Atheneum, 3rd series 3:8 (15 January 1830), p. 289.

32 North American Magazine, 3: 13 (November 1833), p. 62. The Annual Register, 74 (1832), pp. 209-10, The New Monthly Magazine, new series 36 part 3 (August 1, 1832), pp. 361-2, and The Gentleman's Magazine, 102 (August 1832), p. 183 only listed the title (a second
} 
written by Jane Porter more emphatically declared her a full-fledged bard for enriching her work with 'those bursts from heart and mind, which only poetry can speak, or the voice of music utter. These are the instances in which the poet proves his title to the heaven-gifted name of Vates.'33

Porter never obtained a version of the crowning epithet she accorded Tighe in her 1811 tribute, whom she hailed as the 'Nightingale of Rosanna'. Even Laura Sophia Sweetman's 1832 elegy for Porter only described her listening to a nightingale in her infancy - 'Lo! she is there - in the deep forest shade, / Where, in the hush of winds, the nightingale / Sings to the moon' (lines 1-3) - and finding a temporary spiritual home in Poesy 'on the green hill of youth' (line 18)..$^{34}$ But the Porter sisters' friend Alicia Lefanu repeated Porter's very specific accolade for Tighe when she invoked Tighe in her 1823 novel The Outlaw..$^{35}$ As Jane Porter's obituary for Anna Maria Porter noted, Lefanu and the Porter sisters maintained a steady friendship sustained through correspondence: 'personally, they had only met once; and, as they lived at a distance from each other, their literary, rather than their private, qualities were most known to each other' (pp. 275-6). When Anna Maria Porter died, Lefanu expressed sympathy and asked for an account of her private character, which Jane Porter sent in a letter she reprinted in the obituary itself (comprising three of its eight pages). Novelist, poet, and biographer Alicia Lefanu came from a long line of women writers: her mother was the novelist Elizabeth Sheridan Lefanu; her grandmother was the novelist and dramatist Frances Sheridan; and her aunt was the playwright Alicia Sheridan Lefanu, host of an important Dublin salon that was 'the resort of all the literary people', as her protégé Sydney Owenson (Lady Morgan) put it. ${ }^{36}$ That circle included Tighe, who not only socialized

obituary in The Gentleman's Magazine, 102 [December 1832], pp. 575-8 mentioned her childhood affinity for poetry). The Monthly Traveller, 5: 4 (April, 1834), pp. 134-6 makes no mention at all.

33 Jane Porter, 'Miss Anna Maria Porter', Annual Biography and Obituary, 17 (1833), p. 274. Thomas McClean identifies Jane Porter as the author: 'On September 30, 1832, Porter informed Charles Denham of her intention to write this obituary of her sister' (p. 59). See his 'Jane Porter's Later Works, 1825-1846', Harvard Library Bulletin, 20: 2 (Summer 2009), pp. 45-62, which cites this letter deposited at the Houghton Library, Harvard University, Autograph File (*42M-87).

${ }^{34}$ Laura Sophia Sweetman, 'Pleasant be thy rest, O lovely beam', The Gentleman's Magazine, 102 (December 1832), p. 578. Laura Sophia Temple, later Sweetman (17831848), was the author of three books of poetry: Poems (London: Phillips, 1805), Lyric and Other Poems (London: Longman, 1808), and The Siege of Zaragoza, and Other Poems (London: Miller, 1812).

35 The Outlaw is the first of the two tales Lefanu published in Tales of a Tourist, Containing The Outlaw and Fashionable Connexions, 4 vols. (London: Newman, 1823), 1: pp. 23; 88.

${ }^{36}$ Lady Morgan's Memoirs: Autobiography, Diaries and Correspondence, ed. W. Hepworth Dixon, 2 vols. (London: Allen, 1862), 1: p. 144. See Julia Wright's '“All the Fire-Side 
with but read works by members of the Lefanu and Sheridan family. Her reading journal for 6 June 1806 contains an entry on Elizabeth Lefanu's 1804 novel The India Voyage which remarks 'I should not have read thro' these two volumes I believe to myself as I did in a few hours had they not been sent to me by a sister of the authoress' (NLI 4804). A month earlier Tighe commented on reading Richard Brinsley Sheridan and Nathaniel Brassey Halhed's 1771 translation of the Love of Epistles of Aristaenetus: 'This little vol: was published in 1771 with the signature of $\mathrm{H}$ : S: but Mrs Le Fanu from whom I receiv'd it assur'd me the poetry is her brothers - It is in a style too familiarly low \& too profligate to please me highly but there is something of originality $\&$ the true poet shining throughout all, nay tho a Course $\&$ affronting resemblance, there is a resemblance to the spirit $\&$ expression of Moore. ${ }^{37}$

The scene in The Outlaw that refers to Tighe as the 'Nightingale of Rosanna' occurs at the Limerick country seat of the minor character Mrs. Stratford Gore, a 'literary fine lady' (1: p. 211) who occasionally publishes odes in a provincial magazine but frequently hosts gatherings for her large circle of friends to discuss literary, political, antiquarian, and social matters. During one typical morning levee a disparate group speculates on the origins of the 'celebrated and incomprehensible round towers' that dot Ireland (1: p. 212):

The Roman Catholic priest thought they were belfries, constructed by the monks in the middle ages, and used also for the purpose of watchtowers; the clergyman was of the opinion that the Medes had first erected them; the architect maintained that they were temples of the Persian Magi; the landscape-gardener believed them to be Pyrathias, or firetemples of the druids ... Mrs. Stratford Gore contended for the African sea-champions, mentioned in ancient story, as the founders of them; while Mr. O'Carolan floated in uncertainty between the different claims of the Scythians, Carthaginians, Phoenicians, Medes, and Persians; and could only come to the conclusion, that, whoever had the honour of constructing them, they were unquestionable proofs of the high antiquity of the Irish nation. (1: p. 213)

A heated argument then erupts between two antiquarians on whether Druidism and Christianity circulated from Ireland to Britain, or Britain to Ireland: the Irish Mr. O'Carolan insists that 'Druidism was first introduced by Merlin into Britain from this island, as that Christianity was established among us by the

Circle": Irish Women Writers and the Sheridan-Lefanu Coterie', Keats-Shelley Journal, 55 (2006), pp. 63-72 for discussion of this complex circle.

${ }^{37}$ NLI 4804, 6 May 1806. Dramatist and politician Richard Brinsley Sheridan (17511816) was the older brother of Alicia Sheridan Lefanu and Elizabeth Sheridan Lefanu. 
blessed St. Patrick' (2: p. 217) and cites various authorities, including Giraldus, Geoffrey of Monmouth, St. Patrick, and Colonel Vallencey; the English Mr. Pendennis contends that Stonehenge 'was the glory of Britain, ages before even the Romans set foot in the island' (2: p. 216) and names St. George and Doctor Campbell as his authorities. ${ }^{38}$ This dispute about national origins, historical authorities, and cultural transmission abruptly ends with the arrival of the poet Mr. Moreville - an undisguised signature for Thomas Moore - whom Mrs. Gore hails as the 'Bard of Ovoca'. When she asks him to speak of 'the particulars of your pilgrimage, what shrines you last have visited, and what charms you have sung' (1: p. 218), he names two sites: "the patriot shades of Tinnahinch"' (the home of Henry Grattan) and "the now-deserted bower of Psyche!" (1: p. 219).

For Lefanu to preface her invocation of Tighe as the 'Nightingale of Rosanna' with a discussion of national origins and legitimating authorities, and to equate Tighe with Grattan, suggests something about the place Tighe holds in her larger narrative of Irish and women's history. As Julia Wright argues, Lefanu's novel 'deals extensively with aristocratic men who fail to act as patriots and fathers, it attributes those failures to a range of causes and juxtaposes them all with a woman's successful governance. ${ }^{39}$ Here Lefanu explicitly positions Tighe as a female authority who embodies the spirit of Ireland through her authorship of an epic romance that features a woman who not only dares to look at what she is forbidden to see but one who actively pursues the restoration of domestic harmony. Tighe's Psyche provides an origin myth for the national romance Lefanu scripts in The Outlaw, which offers a critical view of the aftermath of the Irish Rebellion and emphasizes the strong role women can play in repairing the nation:

the discourse turned on the lady to whom he had alluded, under the name of Psyche, from the circumstance of her being the author of the beautiful poem which bears that title. Her loss, though not very recent, continued to be lamented by all ... Moreville, as if willing to charm away the spirit of melancholy he had raised, exclaimed - 'Come, shall I give you the last strain which I dedicated to the "Nightingale of Rosanna?" (1: pp. 219-20)

The song Moreville sings is 'When Time, who steals our years away' (1: pp. 219-20), which Moore published in 1802 as 'A Ballad Dedicated to

38 Thomas Campbell's Strictures on the Ecclesiastical and Literary History of Ireland till the Introduction of the Roman Ritual, and the Establishment of Papal Supremacy by Henry II (Dublin: Luke White, 1789) positioned itself against the Irish antiquarian histories of Charles Vallencey and Charles O'Conor (among others).

${ }^{39}$ Julia M. Wright, Representing the National Landscape in Irish Romanticism (Syracuse: Syracuse University Press, 2014), p. 120. 
Mrs. Henry Tighe of Rosanna', and would have performed at Alicia Sheridan Lefanu's salon. ${ }^{40}$ Lefanu significantly transforms the dedication of Moore's publication - the 'Mrs. Henry Tighe of Rossana' - to reclaim Tighe as the 'Nightingale of Rosanna', expanding the citational series that links her with Porter, Barbauld, and Tighe in a network of female authorship. And just as this episode in the novel insists on the primacy of female authority and advocacy, so too does the frame narrative for Tales of a Tourist, which contains The Outlaw (and a second novel, Fashionable Connections). Tales of a Tourist opens with the return of the newly married Lady Llanvair to her ancestral home in Wales (and carefully reports that she is richer than her husband, whom she marries for love). When the countess accidentally meets her old friend Trevallyn, an unsuccessful writer, she promises to support his efforts by soliciting the help of a third friend, a duchess: "we will join forces, and maintain against all gainsayers, that the Tales of a Tourist deserve a reading. You may then publish without dread of satire. - Ah Trevallyn!" pursued the countess, after interrupting herself, "I know what that flushed brow and indignant look would say. What! shall I owe my safety or success to patronage, and female patronage too! And why not?"' (1: p. 19). As the countess and her spouse walk away, her spouse declares "It is thus female influence should indeed be exerted"' (1: p. 20).

While Lefanu positions both Tighe and herself as significant and supportive female influences and authorities in The Outlaw, their sister salonnière Lady Morgan provides a more equivocal invocation of Tighe in her 1827 novel The O'Briens and the O'Flahertys, a roman à clef largely situated in the months leading up to the Irish Rebellion. Like The Outlaw, The O'Briens and the O'Flahertys asserts the greater viability of female governance and reverses the familiar representation of Erin as the feminized nation that needs to be saved by the masculine patriot. Morgan's female hero Beavoin O'Flaherty frequently rescues the flailing protagonist Murrogh O’Brien - professional soldier, Dublin Volunteer, Trinity College student, and United Irishman - from morally and materially dangerous encounters. These encounters often entail seductions in which Murrogh stands as the specularized object, subject to the colonizing gaze of powerful women like Lady Knocklofty, 'female chief of that great oligarchical family, the Proudforts - a family on which the church rained mitres, the state coronets, and the people - curses ${ }^{4}{ }^{41}$ In volume two, the disguised and cross-dressed Lady Knocklofty wins a game of forfeits by securing Murrough's release from prison and escorting him to a Dublin vice-regal party, where she presents him to the 'vice-queen', the Duchess of Belvoir (wife of the reigning

${ }^{40}$ Thomas Moore, When Time, who steals our years away: A Ballad Dedicated to Mrs. Henry Tighe (London: John Carpenter, 1802).

${ }^{41}$ Sydney Owenson (Lady Morgan), The O'Briens and the O'Flahertys: A National Tale, ed. Julia M. Wright (Ontario: Broadview, 2013), p. 106. 
Lord Lieutenant). Morgan's narrator cites two lines from the fifth canto of Tighe's Psyche - the only canto where male power has no efficacy - to describe the circle of intimates surrounding the Duchess:

The intimates, or particular cortège of the vice-queen now drew near, and took their places, as ease and grace directed, round her, who, though many among the attendant graces were all divine -

\section{'Yet still the fairest queen,}

Like Dian 'midst her circling nymphs, appeared'.42

The group was picturesque, and with its accessories of light and shade, of ponderous mirrors, and grotesque girandoles, would have painted well. (p. 187)

Just before the citation of these lines from Psyche, the narrator reports that 'some histrionics of the private theatricals were holding forth on the rival merits of Mrs. O'Neil and Mrs. Gardiner' (p. 187) and provides a telling footnote: 'Two beautiful and accomplished leaders of what was best and most intellectual in the Irish bon ton of the day. The poetical productions of Mrs. O'Neil were as admirable of those of her friend Mrs. Greville' (p. 187). The ironic contrast the narrator draws between the valuable intellectual activities of the female poets among the Irish bon ton and the vapid frolics of the vice-queen's court becomes even more pronounced in light of the Psyche episode cited, where Psyche visits the palace of Castabella (queen of chastity) and raptly listens to Castabella's nymphs sing a sixteen-stanza hymn to 'the triumphs of their spotless queen' (canto 5, line 186, p. 126) that delineates a history of women's resistance to sexual subjugation. Thus the narrator's invocation of this particular section of Tighe's Psyche not only rebukes the decadent pursuits of the vice-queen's circle, it subtly reinforces the preface's assertion that literature provides a means of political power or patriotic expression for women writers. ${ }^{43}$

${ }^{42}$ Mary Tighe, 'Psyche; or, the Legend of Love', in The Collected Poems and Journals of Mary Tighe, ed. Harriet Kramer Linkin (Lexington: University Press of Kentucky, 2005), canto 5, lines 145-6, p. 125. Morgan changes Tighe's 'mid' to 'midst'.

${ }^{43}$ Susan Egenolf offers a particularly rich reading of the novel's editorial voice and glosses in “'Have you Irish?”: Heroism in Morgan's The O'Briens and the O'Flahertys', The Art of Political Fiction in Hamilton, Edgeworth and Owenson (Farnham: Ashgate, 2009), pp. 157-84. Also see Wright's introduction to the Broadview edition, which observes that the narrator is 'the most likely to refer to non-dramatic Irish literature, most predictably Irish historians such as Curry, Keating, O'Conor, O'Halloran, and Walker, who round out the historical dimensions of the novel, but also poets and satirists such as Goldsmith, Moore, O’Kelly, Swift, and Tighe' (p. 28). 
Although this reading posits that Morgan's narrator cites Psyche as a rebuke to the unchaste activities the chapter details, the invocation simultaneously effects an uncomfortably sympathetic or complicit affiliation between Tighe and the vice-regal court of the 1790s, where she did, indeed, shine: in Elizabeth Blackburne's words, 'she was the centre of attraction in the brilliant vice-regal court of Dublin'. ${ }^{44}$ The ambiguity of the narrator's gloss from Psyche is heightened four sentences later when the narrator uses a line from Tighe's friendship poem 'The Shawl's Petition, to Lady Asgill' (c. 1806-9) to describe Lady Knocklofty's outfit:

Lady Knocklofty (in the same turban and caftan, in which, a night or two before, she had played Roxalana), imaged one of those -

'Forms

Which the bright sun of Persia warms'. (p. 188)

Just as Roxalana represents a figure of great female power - Haseki Hürrem Sultan, initially slave, then favorite consort, and finally wife of and arguably co-ruler with Ottoman Sultan Suleiman the Magnificent - the 'fairest form' the shawl petitions is its former possessor, the socially prominent Lady Asgill, friend to Tighe and Morgan, and wife of the British general Sir Charles Asgill, who fought against the colonists in the American Revolution, suppressed the rebels in the Irish Rebellion, and commanded the Dublin garrison from 1797 to 1805 :

\author{
Oh, fairer than the fairest forms \\ Which the bright sun of Persia warms, \\ Though nymphs of Cashmire lead the dance \\ With pliant grace, and beamy glance; \\ And forms of beauty ever play \\ Around the bowers of Moselay; \\ Fairest! thine ear indulgent lend, \\ And to thy suppliant Shawl attend!
}

(lines 1-8, Collected Poems and Journals, p. 193)

In the poem the shawl expresses its willingness to have left its native home in the 'East' to serve as a complement to Lady Asgill's beauty, its unhappiness at having been 'exiled' to Tighe's sick room as a gift, and its hope for a return to Lady Asgill, but if not, then at least the occasional compensation of a visit:

${ }^{44}$ E. Owens Blackburne, 'Mrs. Mary Tighe', Illustrious Irishwomen, 2 vols. (London: Tinsley, 1877), 2: p. 53. Blackburne refers to Tighe's debut in the early 1790s. 
'Restore thy sweet society, / And bless at once thy friend and me' (lines 49-50). While the poem offers a stunning exposé of the impact of colonization on the colonized, Tighe may not be making a conscious or deliberate critique in her avowal of Lady Asgill's gift. Thus the narrator's gloss operates even more equivocally here than in the citation from Psyche.

Lady Asgill would have presented the shawl to Tighe during one of her visits to Tighe's home on Dominick Street, where Tighe hosted what her cousin Caroline Hamilton's journal described as 'little evening parties' for her literary circle in 1806-7, which included the young and ambitious Sydney Owenson: 'she had often little evening parties where Moore sang his sweetest songs to a few (perhaps not more than eight or ten) of those who were then most esteemed in Dublin, for rank or talents. ... Lady Morgan, then Miss Owenson, was often invited to tea to entertain the company, tho' Mary neither liked nor esteemed her, but she tried to bring together those who could talk to amuse her' (Collected Poems and Journals, p. 263). ${ }^{45}$ Tighe's few surviving notes to Owenson suggest greater fondness than Hamilton accords, and indicate that Tighe not only took an interest in furthering Owenson's career by introducing her to important members of society like Lady Charlemont but also shared her work with Owenson. In November 1806 she writes 'My Dear Glorvina, Lest in your poetical flights you should forget to-morrow evening, this is to request you will come early, and bring your best looks and best spirits; the beautiful Lady Charlemont is coming to meet you expressly. Lady Asgil brings Sir Arthur Wellesley, and William Parnell joins us as soon as he can - so come'. ${ }^{46}$ In June 1809 she affectionately chastises

Naughty Glorvina! You promis'd me fair but here I have been ten days $\&$ not a line from your highness's hand - I send you the 'lily' however, tho' I suppose you have forgotten it \& the writer - I hope your eyes are quite well \& brilliant as ever, inflicting no sufferings on yourself at least whatever they may do on the male part of the creation - Are you most occupied with Merrion square or Hindostan \& do you intend to perform your promise \& indulge with copious sheets of whim \& folly Yrs truly $\mathrm{MBT}^{47}$

In December 1809 a letter from Lady Charleville to Owenson corroborates this counterpoint to Hamilton's view: 'I am grieved to find Mrs. Henry Tighe is

45 See Prendergast's overview of Tighe's salon, where she suggests the salon may have continued through 1809 (169-73).

${ }^{46}$ Lady Morgan, The Book of the Boudoir, 2 vols. (New York: Harper, 1829), 1: pp. 55-6.

${ }_{47}$ MS GEN 1126 Box 2, Beinecke Rare Book and Manuscript Library, Yale University, New Haven. Tighe refers to her poem 'The Lily. May, 1809' (Collected Poems and Journals, pp. 202-3). 
very ill; I know how good she has been to you; and I think her taste should bias every creature who has a heart to feel for her, or soul to acknowledge her, as the first genius of her day'. ${ }^{48}$ Although Tighe's journal entries on Owenson's works offer some harsh criticism, they also offer high praise, and indicate that Tighe read everything Owenson published: she frequently expresses impatience with the 'pedantic affectation' she finds in St. Clair, The Wild Irish Girl, The Lay of an Irish Harp, and Patriotic Sketches of Ireland, but lauds the 'picturesque description', 'true feeling', and 'vast deal of talent' she finds in St. Clair, The Wild Irish Girl, The Novice of Saint Dominick, and Woman: Or Ida of Athens, and repeatedly asserts that Owenson 'has undoubted genius. ${ }^{49}$ After Tighe's death Morgan mourned the passing of 'dear Psyche' in a 7 June 1812 letter to Alicia Sheridan Lefanu which notes all 'the changes that have taken place in the little circle of my intimacy within a few years' ${ }^{50}$ But fifteen years later, when Morgan's narrator invokes Tighe in The O'Briens and the O'Flahertys, she both acknowledges and distances herself from the 'dear Psyche' and 'naughty Glorvina' of those long ago days, in as complex a manner as the Lady Morgan of 1846 who differentiates herself from the Sydney Owenson of 1806 when she prepared her revised edition of The Wild Irish Girl for Colburn's Standard Novels series, whose title page identifies the work as 'The Wild Irish Girl. By Sydney Owenson. Edited by Lady Morgan'.51

If Morgan both acknowledges and yet repudiates Tighe in the complicated set of citations she presents in The O'Briens and The O'Flahertys, so too the final writer this essay will take up, Felicia Hemans, who offers an artfully anonymous tribute to Tighe in her 1827 'The Grave of a Poetess', which she subsequently positions as the final lyric record in her 1828 collection Records of Woman, the only record written for a contemporary woman and poet. As the rich body of criticism on this poem notes, Hemans never refers to Tighe explicitly in the body of the poem but reveals the identity of 'the poetess' as 'the author of Psyche' in a footnote to the title that cites the Tales by the

\footnotetext{
${ }^{48}$ Lady Morgan's Memoirs, 1: p. 384.

49 Tighe's reading journal contains entries for St. Clair on 29 April 1806, for The Wild Irish Girl on 8 November 1806, for The Novice of Saint Dominick in December 1806, for The Lay of an Irish Harp on 12 April 1807, for Patriotic Sketches of Ireland on 16 November 1807, and for Woman; Or Ida of Athens in January 1809. Tighe also makes multiple references to Owenson in her letters to Joseph Cooper Walker, MS 1461/5-7, Trinity College Library, Dublin.

${ }^{50}$ Lady Morgan's Memoirs, 2: p. 22.

${ }^{51}$ I owe this observation to Ina Ferris, who cites the 1846 title page after a discussion of Morgan's 1829 preface 'To the Reader' for The Book of the Boudoir, and goes on to note that 'even as it conveniently distances her from the embarrassing effusions of her younger self, the divided signature attests to her persistent wariness of unitary bodies and single names' (The Romantic National Tale and the Question of Ireland [Cambridge: Cambridge University Press, 2002], p. 153).
} 
O'Hara Family (John Banim's 1825 The Fetches): 'Extrinsic interest has lately attached to the fine scenery of Woodstock, near Kilkenny, on account of its having been the last residence of the author of Psyche. Her grave is one of many in the church-yard of the village ${ }^{52}$ Like Anna Maria Porter, Hemans makes a surprising connection between Tighe and Staël's Corinne through the epigraph that follows the title, which quotes an epitaph that Corinne views as she wanders through the church of Santa Croce: "Ne me plaignez pas - si vous saviez / Combien de peines ce tombeau m'a epargnées!"’33 Thus Hemans not only frames one of her most powerful explorations of poetic legacy with references to Tighe and Staël, she invokes Porter's 1811 homage to Tighe and Staël as she contemplates what it means to succeed or fail as a woman and artist, and therein brings this essay full circle.

As Hemans imagines herself standing over the grave she had not yet seen (but would visit three years later), she subtly evokes Tighe's poetry in her opening lines: 'I stood beside thy lowly grave; - / Spring-odours breath'd around' (lines 1-2). The second line carefully echoes the first line of Tighe's final poem 'On Receiving a Branch of Mezereon Which Flowered at Woodstock. December 1809': 'Odours of Spring, my sense ye charm' (Collected Poems and Journals, p. 204). Significantly, 'The Mezereon' is not only Tighe's final poem, it is a poem that correctly anticipates her death four months later; it is the poem that concludes the posthumous edition of Psyche, with Other Poems her family published in 1811, just as 'The Grave of a Poetess' concludes Records of Woman; and it is a poem that makes a very specific request of Tighe's survivors:

My last sad claim receive!

Oh! do not quite your friend forget,

Forget alone her faults;

And speak of her with fond regret

Who asks your lingering thoughts. (lines 44-8)

52 Felicia Hemans, 'The Grave of a Poetess', New Monthly Magazine, new series 20 (1827), pp. 69-70, reprinted in Records of Woman: With Other Poems (Edinburgh: Blackwood, London: Cadell, 1828). Three particularly detailed discussions occur in Samantha Matthews' Poetical Remains: Poets' Graves, Bodies, and Books in the Nineteenth Century (Oxford: Oxford University Press, 2004), pp. 77-112, Brandy Ryan's “"Echo and Reply": The Elegies of Felicia Hemans, Letitia Landon, and Elizabeth Barrett', Victorian Poetry, 46: 3 (2008), pp. 249-77, and Paul Westhover's 'Imaginary Pilgrimages: Felicia Hemans, Dead Poets, and Romantic Historiography', Literature Compass, 2 (2005), RO 112, 1-16.

${ }^{53}$ Avriel Goldberger translates these lines as 'Do not pity me .... If you only knew how many sorrows this tomb has spared me!' in Corinne, or Italy (New Brunswick: Rutgers University Press, 187), p. 367. 
Tighe asks her survivors to remember her. Hemans fulfills that request with perhaps a little too much precision in speaking of Tighe with fond regret in a second allusion to 'The Mezereon' - 'Here a vain love to passing flowers / Thou gav'st' (line 41-2) - but with acute recognition in offering textual invocations of Psyche in the final two stanzas. In the next-to-last stanza, Hemans exclaims 'Thou hast left sorrow in thy song, / A voice not loud, but deep! / The glorious bowers of earth among, / How often didst thou weep!' (lines 45-8), lines that refer to Tighe's epic beginning, which presents Psyche weeping in a bower: 'Fair Psyche through untrodden forests went, / To lone shades uttering oft a vain lament. / ... / Here the young branches shot their arms athwart, / And wove the bower so thick in every part' (canto 1, lines 4-14, p. 57). In the final stanza Hemans recalls the extraordinary ending of Tighe's poem, where Tighe mourns her return to the 'mortal ground' of reality from the visionary world of imagination and poetry. Hemans asks 'Where couldst thou fix on mortal ground / Thy tender thoughts and high? - / Now peace the woman's heart hath found, / And joy the poet's eye' (lines 49-52). Tighe writes of 'dark oblivion's silent tomb':

Dreams of Delight farewel! your charms no more

Shall gild the hours of solitary gloom!

The page remains - but can the page restore

The vanished bowers which Fancy taught to bloom?

Ah no! her smiles no longer can illume

The path my Psyche treads no more for me;

Consigned to dark oblivion's silent tomb

The visionary scenes no more I see,

Fast from the fading lines the vivid colours flee!

(canto 6, lines 532-40, p. 151)

In 'The Grave of a Poetess' Hemans inscribes a deft tribute to 'the author of Psyche' that ultimately seeks to secure her own reception via the poem's citational network. As Labbe and Matthews observe, the 'poet's eye' becomes the 'poet's I', with Hemans subsuming Tighe in a discursive act that Paul Westhover usefully labels auto-canonization. ${ }^{54}$

When Hemans does visit Tighe's grave in 1831, she has the opportunity to read Tighe's manuscripts, which she addresses in one of her final poems, the 1834 'On Records of Immature Genius, Written after reading Memorials of the late Mrs. Tighe' (published in the posthumous 1836 Poetical Remains). Her letters never indicate whether she looked through Tighe's reading journal, or saw the following entry for 29 July 1808: 'Poems of F. D. Browne aged 13

${ }^{54}$ Labbe, p. 141; Matthews, p. 96; Westhover, p. 6. 
very wonderful considering them as they are the works of a beautiful child' (NLI 4804). But her letters do mention the disappointment she experienced in seeing John Flaxman's statue of Tighe in the family mausoleum, with its peculiar Psyche figure perched on top of Tighe's reclining head, 'a very small Titania-looking sort of figure with wings, which I thought interfered wofully with the singleness of effect which the tomb would have produced'.55 The first version of the poem Hemans wrote to commemorate the experience, her 1831 'To a Butterfly Near a Tomb', occludes even an oblique mention of Tighe; the forty-line lyric presents a speaker at an anonymous tomb immersed in dark thoughts that are interrupted by a passing butterfly whose flight becomes an inspiring image of the soul's transcendence: 'I stood where the lip of Song lay low, / Where the dust was heavy on Beauty's brow; / Where the stillness hung on the heart of Love, / And a marble weeper kept watch above' (lines 1-4). ${ }^{56}$ Only the closest of Hemans' friends might guess the site or subject through the coded reference to the marble weeper, a factor that notably changes in Hemans' revision of the poem for her 1834 volume National Lyrics, and Songs for Music, where she makes the references to Tighe explicit. Retitled 'Written After Visiting a Tomb, Near Woodstock, in the County of Kilkenny', a clear echo of the title of the penultimate poem in printed in Psyche, with Other Poems, 'Sonnet Written at Woodstock, in the County of Kilkenny, the Seat of William Tighe. June 30, 1809', Hemans thoroughly utilizes the epigraph effect in citing the fourth stanza of Tighe's most famous lyric, 'The Lily. May 1809', and directly attributing the epigraph to 'Mrs. Tighe':

\section{Yes! hide beneath the mouldering heap, \\ The undelighting, slighted thing; \\ There in the cold earth, buried deep, \\ In silence let it wait the Spring.}

Mrs. Tighe's Poem on the Lily. ${ }^{57}$

Furthermore, she adds a stanza that not only makes the number of lines in her poem match the number of lines in 'The Lily' (eleven quatrains), the new ninth stanza returns attention to Tighe as the dead body in the tomb, unlike the first iteration of the poem, which stays focused on the butterfly: 'And she, that voiceless below me slept, / Flow'd not her song from a heart that wept?' (lines 33-4).

55 Letter to John Lodge, July 1831, Felicia Hemans: Selected Poems, Letters, Reception Materials, ed. Susan J. Wolfson (Princeton: Princeton University Press, 2000), p. 514.

56 'To a Butterfly Near a Tomb', Blackwood's Edinburgh Magazine, 30 (September 1831): p. 530.

${ }^{57}$ National Lyrics, and Songs for Music (Dublin: Curry, London: Simpkin \& Marshall, 1834), pp. 324-7. 
In Tighe's poem the lily's resurgence each spring from a 'withered, perished ... obscure unsightly root' (lines $1-2$, p. 30) presages the soul's emergence from a material body into an eternal spring:

So Faith shall seek the lowly dust

Where humble Sorrow loves to lie,

And bid her thus her hopes entrust,

And watch with patient, cheerful eye;

And bear the long, cold, wintry night,

And bear her own degraded doom,

And wait till Heaven's reviving light,

Eternal Spring! shall burst the gloom. (lines 37-44, p. 31)

With Tighe's poem and tomb clearly marked as the object of contemplation in 'Written After Visiting a Tomb, Near Woodstock, in the Country of Kilkenny', Hemans effectively recasts Tighe's metaphor so that Tighe's entombed body constitutes the root that ultimately flowers in Hemans' song, thus positioning Hemans as Tighe's successor in another instance of auto-canonization, with Hemans literally speaking over 'she, that voiceless below me slept' (line 33), singing a song for Tighe (and herself) that flows from her own weeping heart: 'Flow'd not her song from a heart that wept?' (line 34). Now the butterfly that interrupts Hemans' thoughts not only provides a generic image of the soul's transmigration, it specifically invokes Tighe's Psyche (both soul and butterfly in ancient Greek) and glosses or even supplants Tighe's analogous image of the lily. Most importantly, the poem's concluding stanza suggests that the butterfly's flight marks the transfer of genius from Tighe to Hemans: 'Thou dost image the freed soul's birth, I And its flight away o'er the mists of earth, / Oh! fitly thy path is through the flowers that rise / Round the dark chamber where Genius lies!' (lines 41-4). In 1831 the penultimate line read 'Oh! fitly Thou shinest mid the flowers that rise' (line 39); the subtle but potent shift from 'Thou shinest mid' to 'thy path is through' (line 43) underscores the role Hemans assigns herself in this second poem about Tighe's grave, which, like 'The Grave of a Poetess', presents Hemans as the inheritor of the poetess's crown. If Hemans offers an unambiguous invocation of Tighe in the epigraph for 'Written After Visiting a Tomb', she also firmly seals her in the encrypted body of the poem; unlike the footnoted 'author of Psyche' whose 'voice not loud, but deep!' filters through the echoing lines of 'The Grave of a Poetess' (line 46), the 'Mrs. Tighe' who authors 'The Lily' is completely silenced in Hemans' 'Tomb', where 'she, that voiceless below me slept' (line 33). 
Hemans' first tribute to Tighe famously initiates an elegiac chain that constitutes a map of female authorship and succession for nineteenth-century women poets, linking Tighe ('The Mezereon'), Hemans ('The Grave of a Poetess'), Letitia Elizabeth Landon ('Stanzas on the Death of Mrs. Hemans', 'Felicia Hemans'), Elizabeth Barrett Browning ('Stanzas Addressed to Miss Landon, and Suggested by Her 'Stanzas on the Death of Mrs. Hemans', 'L. E. L.'s Last Question'), and Christina Rossetti ('L. E. L.'), among others (such as Maria Jane Jewsbury, Dora Greenwall, or Emily Dickinson). ${ }^{58}$ That extended elegiac chain is as well established in twentieth- and twenty-firstcentury literary criticism as the citational network inspired by Staël: both demonstrate how women writers attempt to inscribe their own traditions of authorship, establish their own histories of influence, and declare their own affiliations with one another to pre-emptively predicate their reception and literary reputations. How many more might we locate in tracing the references and invocations nineteenth-century women writers provided as they sought to construct their own canons? This essay only begins to explore the citational network that emerges around the figure and work of Mary Tighe as Anna Maria Porter, Anna Barbauld, Alicia Lefanu, Lady Morgan, and Felicia Hemans call attention to her significance and therein establish their own histories of influence and reception. It does not include Mary Brunton, whose 1814 novel Discipline performs the sort of literary kidnapping and taste-making Clery attributed to Radcliffe in using excerpts from Tighe, Joanna Baillie, and Smith for three of her thirty chapter epigraphs (alongside Shakespeare and male company). ${ }^{59}$ It does not include Susan Ferrier, whose 1824 novel The Inheritance offers a truly funny yet poignant episode in which the heroine's unsophisticated relatives butcher the pronunciation of Psyche while they are examining some finely bound books:

'This is beautiful', said Mrs. Larkins, displaying some fine engravings in one of them to her sisters-in-law; - 'I never saw this before, "Fisk, by Mrs. Tigg"', - reading the title of it.

'Fishie, my dear', whispered Mr. Larkins, as if a little ashamed of her mal-pronunciation.

'Dear! is that Peseechye?' said Miss Larkins; - 'a sweet, purty thing it is'.

${ }^{58}$ See Angela Leighton's Victorian Women Poets: Writing Against the Heart (Charlottesville: University Press of Virginia, 1992); Derek Furr's 'Sentimental Confrontations: Hemans, Landon, and Elizabeth Barrett', English Language Notes, 40. 2 (2002), pp. 29-47; Ryan's "'Echo and Reply", and Labbe.

59 Brunton cites Psyche canto 6, lines 247-52 for the epigraph of Chapter Five in Discipline (Edinburgh: Ramsay, 1814), p. 96. 
Gertrude could almost have cried at this Malaprop murder of 'Psyche, by Mrs. Tighe', while the Duchess had recourse to her little affected cough, to conceal the play of her muscles. ${ }^{60}$

Nor does it include any unpublished citations, such as the tributary Spenserian stanza Mary Leadbeater sends to Melesina Trench in 1812 after she receives and reads through her own copy of Psyche, with Other Poems, opening up an intriguing aesthetic connection:

Genius of Spencer, dost thou hover near The favoured banks of Mulla's pastoral stream?

Or midst Rosanna's groves, to science dear, Lovest thou to bid thy former lustre beam? Alas! how short-lived this delicious gleam! How soon are closed in everlasting sleep Those eyes which caught new radiance from the theme! Now, while their tears the flowers of fancy steep, Sad Psyche and her love o'er the pale marble weep. ${ }^{61}$

All these references, invocations, acknowledgments and occasional repudiations of Tighe and her work chart a set of influences and an alternate course of literary history that underscores the significance women writers found in one another's works and their own efforts to construct what we call Romanticism by building citational networks.

\section{Bibliography}

Baxandall, Michael. Patterns of Intention: On the Historical Explanation of Pictures.

New Haven: Yale University Press, 1985.

Behrendt, Stephen C. British Women Poets and the Romantic Writing Community. Baltimore: Johns Hopkins University Press, 2009.

'Biographical Memoir of Miss Anna Maria Porter'. New British Lady's Magazine, 3 (July 1819).

Blackburne, E. Owens. 'Mrs. Mary Tighe'. Illustrious Irishwomen. 2 vols. London: Tinsley, 1877.

Bloom, Harold. The Anxiety of Influence: A Theory of Poetry. New York: Oxford University Press, 1973.

—. A Map of Misreading. New York: Oxford University Press, 1975.

${ }^{60}$ Susan Ferrier, The Inheritance, 3 vols. (Edinburgh: Blackwood, London: Cadell, 1824), 3: pp. 116-17.

${ }_{61}$ Mary Leadbeater to Melesina Chenevix Trench, 1 June 1812; The Leadbeater Papers, 2 vols., $2^{\text {nd }}$ edn. (London: Bell and Daldy, 1862), 2: p. 234. 
Brunton, Mary. Discipline. Edinburgh: Ramsay, 1814.

Campbell, Thomas. Strictures on the Ecclesiastical and Literary History of Ireland till the Introduction of the Roman Ritual, and the Establishment of Papal Supremacy by Henry II. Dublin: Luke White, 1789.

Clayton, Jay and Eric Rothstein. Influence and Intertextuality in Literary History. Madison: University of Wisconsin Press, 1991.

Clery, Emma J. Women's Gothic: From Clara Reeve to Mary Shelley. Devon: Northcote House, 2000.

Coleridge, Samuel Taylor. Christabel; Kubla Khan: A Vision; The Pains of Sleep. London: John Murray, 1816.

Cox, Jeffrey. Poetry and Politics in the Cockney School: Keats, Shelley, Hunt and Their Circle. Cambridge: Cambridge University Press, 2004.

Egenolf, Susan. "'Have you Irish?": Heroism in Morgan's The O'Briens and the O'Flahertys'. The Art of Political Fiction in Hamilton, Edgeworth and Owenson. Farnham: Ashgate, 2009.

Ferrier, Susan. The Inheritance. 3 vols. Edinburgh: Blackwood, London: Cadell, 1824.

Ferris, Ina. The Romantic National Tale and the Question of Ireland. Cambridge: Cambridge University Press, 2002.

Furr, Derek. 'Sentimental Confrontations: Hemans, Landon, and Elizabeth Barrett'. English Language Notes, 40: 2 (2002).

Genette, Gerard. Paratexts: Thresholds of Interpretation, trans. Jane E. Lewin. Lincoln: University of Nebraska Press, 1997.

Gilbert, Sandra and Susan Gubar. The Madwoman in the Attic: The Woman Writer and the Nineteenth-Century Literary Imagination. New Haven: Yale University Press, 1979.

H. 'Contemporary Poets and Writers of Fiction. No. XII. - Miss Anna Maria Porter'. La Belle Assemblée, or Court and Fashionable Magazine, new series 4: 22 (October 1826).

Hemans, Felicia. Felicia Hemans: Selected Poems, Letters, Reception Materials, ed. Susan J. Wolfson. Princeton: Princeton University Press, 2000.

—. 'The Grave of a Poetess'. New Monthly Magazine, new series 20 (1827). Reprinted in Records of Woman: With Other Poems. Edinburgh: Blackwood, London: Cadell, 1828.

-. National Lyrics, and Songs for Music. Dublin: Curry; London: Simpkin \& Marshall, 1834.

—. 'To a Butterfly Near a Tomb'. Blackwood's Edinburgh Magazine, 30 (September 1831).

'Illustrative Memoir of Miss Jane Porter'. The Atheneum, new series 3: 8 (July 15, 1825).

Keats, John. The Letters of John Keats, ed. Hyder Edward Rollins. 2 vols. Cambridge: Harvard University Press, 1958.

Kucich, Greg. 'Gender Crossings: Keats and Tighe'. Keats-Shelley Journal, 44 (1995). 
Labbe, Jacqueline. 'Re-membering: Memory, Posterity, and the Memorial Poem', in Memory and Memorials, 1789-1914: Literary and Cultural Perspectives, ed. Matthew Campbell, Jacqueline M. Labbe, and Sally Shuttleworth. London: Routledge, 2000.

Leadbeater, Mary. The Leadbeater Papers. 2 vols. $2^{\text {nd }}$ edn. London: Bell and Daldy, 1862.

Lefanu, Alicia. Tales of a Tourist, Containing The Outlaw and Fashionable Connexions. 4 vols. London: Newman, 1823.

Leighton, Angela. Victorian Women Poets: Writing Against the Heart. Charlottesville: University Press of Virginia, 1992.

Levy, Michelle. Family Authorship and Romantic Print Culture. New York: Palgrave Macmillan, 2008.

Linkin, Harriet Kramer. 'Mary Tighe and Literary History: the Making of a Critical Reputation'. Literature Compass, 7: 7. July 2010.

-. 'Recuperating Romanticism in Mary Tighe's Psyche', Romanticism and Women Poets: Opening the Doors of Reception, ed. Harriet Kramer Linkin and Stephen C. Behrendt. Lexington: University Press of Kentucky, 1999.

Lokke, Kari. Tracing Women's Romanticism: Gender, History and Transcendence. New York: Routledge, 2004.

Longman Archives. MS 1393, University of Reading Library, Reading.

Looser, Devoney. 'The Porter Sisters, Women's Writing, and Historical Fiction', The History of British Women's Writing, 1750-1830, ed. Jacqueline M. Labbe. Hampshire: Palgrave Macmillan, 2010.

McLean, Thomas. 'Jane Porter's Later Works, 1825-1846'. Harvard Library Bulletin, 20: 2 (Summer 2009).

-. 'Nobody's Argument: Jane Porter and the Historical Novel'. Journal for Early Modern Cultural Studies, 7: 2 (2007).

Markley, Arnold. 'Curious Transformations: Cupid, Psyche, and Apuleius in the Shelleys' Works'. The Keats-Shelley Review, 17 (2003).

Matthews, Samantha. Poetical Remains: Poets' Graves, Bodies, and Books in the Nineteenth Century. Oxford: Oxford University Press, 2004.

Mee, Jon. Conversable Worlds: Literature, Contention, and Community 1762 to 1830. Oxford: Oxford University Press, 2011.

'Miss Anna Maria Porter'. The Atheneum, 3rd series 3: 8 (January 15, 1830).

Moers, Ellen. Literary Women: The Great Writers. New York: Doubleday, 1976.

Moore, Thomas. When Time, who steals our years away: A Ballad Dedicated to Mrs. Henry Tighe. London: John Carpenter, 1802.

Morgan, Lady (Sydney Owenson). Lady Morgan's Memoirs: Autobiography, Diaries and Correspondence, ed. W. Hepworth Dixon. 2 vols. London: Allen, 1862.

-. The Book of the Boudoir. 2 vols. New York: Harper, 1829.

'Obituary-Miss Anna Maria Porter'. The Annual Register, 74 (1832).

'Obituary-Miss Anna Maria Porter'. The Gentleman's Magazine, 102 (August 1832). 
'Obituary-Miss Anna Maria Porter'. The Gentleman's Magazine, 102 (December 1832).

'Obituary-Miss Anna Maria Porter'. The Monthly Traveller, 5: 4 (April, 1834).

'Obituary-Miss Anna Maria Porter'. The New Monthly Magazine, new series 36 part 3 (August 1, 1832).

'Obituary-Miss Anna Maria Porter'. North American Magazine, 3: 13 (November 1833).

Orr, Mary. Intertextuality: Debates and Contexts. Cambridge: Polity, 2003.

Owenson, Sydney (Lady Morgan). The O'Briens and the O'Flahertys: A National Tale, ed. Julia M. Wright. Ontario: Broadview, 2013.

Porter, Anna Maria. Ballad Romances, and Other Poems. London: Longman, 1811.

—. 'Elegy to the Memory of Mrs. Robinson'. The Monthly Visitor, 12 (April 1801).

-. 'The Rose. To Laura'. The Monthly Visitor, 10 (July 1800).

-. 'Written After Having Seen a Lovely But Miserable Girl'. The Literary Miscellany; Or, Selections \& Extracts: Classical and Scientific; with Originals, in Prose and Verse. Vol. 5. London: Nicholson, 1804.

-. 'Written After Having Seen a Lovely But Miserable Girl'. The Parnassian Garland. Forming the Poetry of The Monthly Visitor, Vol. I and II. London, 1797.

-. 'Written After Having Seen a Lovely But Miserable Girl'. The Poetical Register, and Repository of Fugitive Poetry, for 1801. London: Rivington, 1801.

Porter, Jane. 'Miss Anna Maria Porter'. Annual Biography and Obituary, 17 (1833).

Prendergast, Amy. Literary Salons Across Britain and Ireland in the Long Eighteenth Century. New York: Palgrave Macmillan, 2015.

'Review of Ballad Romances, and Other Poems. By Miss Anna Maria Porter'. British Critic, 40 (September 1812).

'Review of Ballad Romances, and Other Poems. By Miss Anna Maria Porter'. Critical Review, 1, series 4 (February 1812).

'Review of Ballad Romances, and Other Poems. By Miss Anna Maria Porter'. Eclectic Review, 8 (April 1812).

'Review of Ballad Romances, and Other Poems. By Miss Anna Maria Porter'. Edinburgh Monthly Magazine and Review (Scotish Review), 1 (September 1812).

'Review of Ballad Romances, and Other Poems. By Miss Anna Maria Porter'. European Magazine, 64 (December 1813).

'Review of Ballad Romances, and Other Poems. By Miss Anna Maria Porter'. Gentleman's Magazine, 83: 2 (December 1813).

'Review of Ballad Romances, and Other Poems. By Miss Anna Maria Porter'. Monthly Review, 67 (March 1812).

'Review of Ballad Romances, and Other Poems. By Miss Anna Maria Porter'. Poetical Register, 8 (1811).

'Review of Psyche, with Other Poems. By the late Mrs. Henry Tighe'. Poetical Register, 8 (1811).

Robinson, Mary. Mary Robinson: Selected Poems, ed. Judith Pascoe. Peterborough: Broadview, 2000. 
-. Memoirs of the Late Mrs. Robinson, Written by Herself. 4 vols. London: Phillips, 1801.

-. Poems, ed. Daniel Robinson, The Works of Mary Robinson, ed. William D. Brewer. 8 vols. London: Pickering \& Chatto, 2009. Vols. 1-2.

Ross, Marlon. The Contours of Masculine Desire: Romanticism and the Rise of Women's Poetry. New York: Oxford University Press, 1989.

Russell, Gillian and Clara Tuite. Romantic Sociability: Social Networks and Literary Culture in Britain, 1770-1840. Cambridge: Cambridge University Press, 2002.

Ryan, Brandy. "Echo and Reply": The Elegies of Felicia Hemans, Letitia Landon, and Elizabeth Barrett'. Victorian Poetry, 46: 3 (2008).

Schmid, Susanne. British Literary Salons of the Late Eighteenth and Early Nineteenth Centuries. Palgrave Macmillan, 2013.

Staël, Germaine de. Corinne, or Italy, trans. and ed. Avriel Goldberger. New Brunswick: Rutgers University Press, 1987.

Sweetman, Laura Sophia. Lyric and Other Poems. London: Longman, 1808.

-. 'Pleasant be thy rest, O lovely beam'. The Gentleman's Magazine, 102 (December 1832).

—. Poems. London: Phillips, 1805.

-. The Siege of Zaragoza, and Other Poems. London: Miller, 1812.

Tighe, Mary. The Collected Poems and Journals of Mary Tighe, ed. Harriet Kramer Linkin. Lexington: University Press of Kentucky, 2005.

—. Letter to Sydney Owenson. MS GEN 1126 Box 2, Beinecke Rare Book and Manuscript Library, Yale University, New Haven.

—. Letters to Joseph Cooper Walker. MS 1461/5-7, Trinity College Library, Dublin.

—. Reading Journal. MS 4804, National Library of Ireland, Dublin.

-. Selena by Mary Tighe: A Scholarly Edition, ed. Harriet Kramer Linkin. Farnham: Ashgate, 2012.

- Verses Transcribed for H. T., ed. Harriet Kramer Linkin. Romantic Circles, 2015. rc.umd.edu/editions/tighe_verses.

Van Remoortel, Marianne. Lives of the Sonnet, 1787-1895: Genre, Gender, and Criticism. Farnham: Ashgate, 2011.

Ward, William. Literary Reviews in British Periodicals, 1798-1820. 2 vols. New York: Garland, 1972.

Westhover, Paul. 'Imaginary Pilgrimages: Felicia Hemans, Dead Poets, and Romantic Historiography'. Literature Compass, 2 (2005), RO 112, 1-16.

Wolfson, Susan J. Romantic Interactions: Social Being and the Turns of Literary Action. Baltimore: Johns Hopkins University Press, 2010.

Wright, Julia M. "All the Fire-Side Circle”: Irish Women Writers and the SheridanLefanu Coterie'. Keats-Shelley Journal, 55 (2006).

-. Representing the National Landscape in Irish Romanticism. Syracuse: Syracuse University Press, 2014. 


\title{
Edgeworth's Letters for Literary Ladies
}

\section{Publication Peers and Analytical Antagonists}

\author{
Robin Runia
}

Maria Edgeworth's role in Romantic women's writing has remained vexed. Her established relationships with her father, Richard Lovell Edgeworth, and author Thomas Day have led many scholars to overlook her as unsatisfyingly conservative in her feminism. At the same time, her perceived lack of relationships with other radical women writers, in particular, Mary Wollstonecraft, have led some critics to overlook her for similar reasons. Despite more recent general consensus among critics regarding the important role Edgeworth plays within late-eighteenth- and early nineteenth-century women's writing, critics remain divided as to its nature. Elizabeth Kowaleski Wallace has argued that Edgeworth's identification with 'masculine literary discourse ... at best creates a female subject according to its own bias and interests.' Similarly, Annette Wheeler Cafarelli and Julia Douthwaite emphasize her intransigent conservatism. ${ }^{2}$ Cafarelli's indictment of Edgeworth as anti-feminist is scathing, arguing that her work 'upholds an essentially conservative position, and indeed, the high copyright payments and the wide distribution of her novels of manners cannot be detached from their affirmation of the status quo. In her works ... the wife is made entirely responsible for the success of the marriage and the happiness of the husband, as well as for driving him to and drawing him from the path of dissipation' (p. 145). In contrast, Anne Mellor and Catherine Gallagher celebrate, respectively, how Edgeworth's educational writing asserts

${ }^{1}$ Elizabeth Kowaleski-Wallace, Their Father's Daughters: Hannah More, Maria Edgeworth, and Patriarchal Complicity (New York: Oxford University Press, 1991), p. 12.

${ }^{2}$ Annette Wheeler Cafarelli, 'Rousseau and British Romanticism', in Cultural Interactions in the Romantic Age: Critical Essays in Comparative Literature, ed. Gregory Maertz (Albany: State University of New York Press, 1998), pp. 125-55. Julia Douthwaite, 'Experimental Child-Rearing After Rousseau: Maria Edgeworth Practical Education and Belinda, Irish Journal of Feminist Studies 2.2 (December 1997), pp. 35-56. 
the equal rights of father and mother and male and female children. ${ }^{3}$ More recently, Catherine Toal has offered a sort of middle ground, suggesting we recognize how Edgeworth's writing focuses 'instead on knowledge and skills useful for entry into an already constituted public or domestic sphere.'

However, re-examination of Edgeworth's Letters for Literary Ladies and its engagements with Day and Wollstonecraft demonstrate that Edgeworth rejected perceived essential associations between women and emotion or intellectual inferiority. Edgeworth's negotiation of the publishing world, her dialogue with both male and female authors, also demonstrates her rejection of arguments on behalf of women's education according to domestic utility. By organizing her intervention in the debate about women's education in letters and a satirical essay in which she assumes male and female voices for specifically male and female readers, she proves her ability, as a woman, to apply reason in defiance of stereotypes. Specifically, by deliberately revising her text in 1798 and acknowledging a divergence between the intended audience of 'A Letter from a Gentleman to his Friend upon the Birth of a Daughter, With the Answer', the 'Letters of Julia and Caroline', and the 'Essay', Edgeworth manifests the equality of women's reasoning outside the confines of a woman's domestic sphere and inside the public world of print. Maria Edgeworth's Letters exemplifies the potential for women writers to speak to their peers, both women and men, while they negotiated the business of eighteenth-century publishing.

Perhaps not surprisingly, the divided critical reception of Edgeworth's work generally is repeated in scholarship devoted to Letters. Much of this has to do with the divided nature of the text itself. In 1795, Edgeworth published the first edition of Letters for Literary Ladies, in which she represents multiple views of women's education and social roles during the late eighteenth century. In 'Letter from a Gentleman to his Friend Upon the Birth of a Daughter', 'Answer to the Preceding Letter', and 'Letters of Julia and Caroline', Edgeworth adopts both male and female voices to reflect contemporary views regarding the propriety and practicality of women's education within the context of women's public and private duties. Edgeworth's addition of a third text, 'An Essay on the Noble Science of Self-Justification' offers a final ironic commentary upon these arguments concerning women's reasoning and its relationship to domestic duty.

${ }^{3}$ Anne K. Mellor, 'A Novel of Their Own: Romantic Women's Fiction, 1790-1830', in John Richetti, ed. The Columbia History of the British Novel (New York: Columbia University Press, 1994), p. 333. Catherine Gallagher, Nobody's Story: The Disappearing Acts of Women Writers in the Marketplace, 1670-1820 (Berkeley: University of California Press, 1995), p. 267.

${ }^{4}$ Catherine Toal, 'Control Experiment: Edgeworth's Critique of Rousseau's Educational Theology' in An Uncomfortable Authority: Maria Edgeworth and Her Contexts, ed. Heidi Kaufman and Chris Fauske (Newark: University of Delaware Press, 2004) pp. 212-34. 
Much of the lack of critical consensus on Letters results from focus on distinct portions of the text rather than on it in its entirety. Marilyn Butler, for example, highlights 'Letter from a Gentleman to his Friend' as Edgeworth's reification of male disapproval regarding women's authorship. ${ }^{5}$ Cafarelli, also focusing on this letter and its response has argued that 'Although modern readers are eager to confer the victory in the debate on the less conservative voice ... the dialogue is at best ambiguous, since neither offers a radical advocacy of women's education. Both disavow being 'a champion for the rights of woman' (p. 137). Even Clíona Ó Gallchoir, in her insightful analysis of Edgeworth's debt to Madame de Genlis's cosmopolitanism, bases her refutation of Cafarelli's conservative reading on a discussion of the first of the volume's letters. She writes: "Letter to a Gentleman' in particular ... bears striking evidence of its post-Revolutionary context, and focuses specifically on the value of women's literary production'. 6

Only in Mona Narain's essay, 'A Prescription of Letters: Maria Edgeworth's Letters for Literary Ladies and the Ideologies of the Public Sphere' do we get an insightful and sustained examination of the first two sets of letters together. In this essay, Narain argues, 'Maria Edgeworth in her very first publication, Letters for Literary Ladies, circumvents dominant, patriarchal literary authority and actively interrogates aspects of it, an act that also allows her to find an authorial voice'. 7 By focusing on Edgeworth's ability to challenge 'aspects' of a dominant patriarchal literary voice, Narain is able to conclude that Edgeworth's authorial intervention depends upon a conservative acceptance that 'women's sphere is the private domestic sphere' and that 'By advising women to eschew power, emptying the domestic sphere of power hierarchies, Edgeworth gains a mediating influence within the public arena and argues for a public voice for women' (pp. 279, 280). Narain determines that while Edgeworth should continue to be recognized as an important woman writer of her period, we should view Edgeworth's feminism as compromised by her proximity to male writers, to male thought, and to the challenges inherent in a woman's navigation of the publishing world.

Edgeworth's biography has done much to cement such views, specifically

${ }^{5}$ Marilyn Butler, 'Edgeworth's Stern Father: Escaping Thomas Day, 1795-1801', in Tradition in Transition: Women Writers, Marginal Texts and the Eighteenth-Century Canon, ed. Alvaro Ribiero and James G. Basker (Oxford: Clarendon, 1996), pp. 75-93.

${ }^{6}$ Clíona Ó Gallchoir, 'Gender, Nation, and Revolution: Edgeworth and de Genlis', in Women, Writing, and the Public Sphere, 1700-1830, ed. Elizabeth Eger, Charlotte Grant, Clíona Ó Gallchoir, and Penny Warburton (Cambridge: Cambridge University Press, 2001), p. 201.

${ }^{7}$ Mona Narain, 'A Prescription of Letters: Maria Edgeworth's "Letters for Literary Ladies" and the Ideologies of the Public Sphere', Journal of Narrative Technique, 28.3 (Fall, 1998), p. 268. 
her relationship to Thomas Day and his relationship to her family. In her Memoirs of her father, Richard Lovell Edgeworth, she records Thomas Day's reaction to news of her intent to publish her translation of Madame Stéphanie Félicité Ducrest de Genlis's Adèle et Théodore, ou Lettres sur l'éducation (1782), an epistolary novel that traces the education of a young son and daughter by their aristocratic parents in a rural setting. Regarding Day's disapproval she wrote, 'At one time, he was nearly of Sir Anthony Absolute's opinion, that the extent of a woman's erudition should consist in her knowing her simple letters, without their mischievous combinations'. ${ }^{8}$ Invoking Richard Brinsley Sheridan's absurd caricature from The Rivals (1775), Edgeworth's lighthearted mocking of the conservative views of a long-time family friend suggests the divergence between her own beliefs and Day's.

While Edgeworth's later rejection in Belinda (1801) of Day's misguided attempt to apply Rousseau to women's education has been recognized by critics, Letters for Literary Ladies has yet to be understood in its entirety as a satire of such attempts. ${ }^{9}$ Further, Day's opinion of Edgeworth's literary ambitions has continued to fuel dominant interpretations of Edgeworth's Letters. According to Butler, 'When the publication of Adelaide and Theodore was cancelled, Day sent Edgeworth a sardonic letter of congratulation, which 'contained an eloquent philippic against female authorship'. Richard Lovell wrote back and the correspondence, or Maria Edgeworth's memory of it, afterwards inspired the first part of Letters for Literary Ladies. ${ }^{10}$ Despite the fact that Butler's reference to the manuscript source of Day's eloquent philippic is missing, Connolly repeats this detail in the introduction to her edition of Letters. She also describes how after another translation of de Genlis's work was published before Maria Edgeworth's and precluded the release of her work, Day was 'delighted', 'He wrote at once to Richard Lovell Edgeworth, congratulating him on saving his daughter from the despicable world of female authorship. Maria Edgeworth based the first two letters in Letters for Literary Ladies on this exchange..1 Thus, Day's celebration of Maria Edgeworth's literary

${ }^{8}$ Maria Edgeworth, Memoirs of Richard Lovell Edgeworth, Esq., Vol. 2 (London, 1820), p. 342 .

${ }^{9}$ Isabell Bour. 'What Maria Learned: Maria Edgeworth and Continental Fiction'. Women's Writing Vol. 18, No. 1 (February 2001), p. 38. Bour writes: 'the inset story of Virginia Saint-Pierre, which is loosely related to the plot of Paul et Virginie (1788) ... more importantly, purports to be a critique of sentimentalism a la Rousseau and a la Bernardin de Saint-Pierre. This inset story is also, more referentially, a satire of the utopian Rousseauian ambitions of Thomas Day, a friend of Richard Lovell Edgeworth, Maria's father'.

${ }^{10}$ Marilyn Butler, Maria Edgeworth: A Literary Biography (Oxford: Oxford University Press, 1972), p. 149.

${ }^{11}$ Claire Connolly, ed. Letters for Literary Ladies by Maria Edgeworth (London: Everyman, 1993), p. xix. 
disappointment has come to determine interpretations of her authorship as a sort of ventriloquism. Significantly, more minute examination of Day's close relationship with the Edgeworth family and their views concerning Rousseau's Émile (1762) reveals what can only be Edgeworth's deliberate irony in assuming Day's voice or a Day-like voice in Letters.

\section{Edgeworth and Day}

From the beginning, Day's acquaintance with the Edgeworth clan was cemented by the mutual concern of all its members for education, and when Richard Lovell's first marriage produced his first child and heir, Day enthusiastically supported the new father's efforts to raise his son according to the radical plan described by Jean-Jacques Rousseau. Eventually, Day's enthusiastic championing of Richard Lovell's experiment transformed into a scheme to apply Rousseau's ideas to his own romantic life and find his own Sophie. Thus, in 1769, Richard Lovell aided Day in a plan to adopt and train two girls as his potential future brides. ${ }^{12}$ Further, in both of his trips to the Foundling Hospital in search of promising girls, Day supplied Richard Lovell Edgeworth's name as the responsible party. Wendy Moore has concluded that while Richard Lovell may not have attended Day on his first trip, it seems likely that he accompanied Day on [his] second visit since Richard Lovell signed the chosen orphan's apprenticeship indentures' (p. 76). For Day, protected from the corruption of leisure and luxury by their own hard work, girls 'must be shaped from infancy to fulfill their subservient role' (p. 48).

Perhaps not surprisingly, Day's application of Rousseau's ideas to the creation of a perfect wife failed. He first discarded the foundling Lucretia after only a year in an apprenticeship to a milliner. In the following year (1771), he dismissed the foundling Sabrina, packing her off to boarding school and an eventual apprenticeship with a dressmaker. Neither Day's ward nor wife, Sabrina was forced to rely on the kindness of others in Day's social circle for economic means. While Sabrina later married and found employment as housekeeper and secretary at Charles Burney's school for boys, Maria Edgeworth's correspondence with Sabrina throughout the rest of their lives testifies to Edgeworth's intimate acquaintance with the lasting social complexities and awkwardness of Day's notorious experiment.

Nevertheless, Day remained committed to his rejection of luxury and class-based inequality in ways that resonated with Edgeworth. After she left school in 1781, Edgeworth stayed with Day twice within the year, 'once in July and once in September' (Butler, Maria, p. 74). And during this period,

12 Wendy Moore, How to Create the Perfect Wife: Britain's Most Ineligible Batchelor and his Enlightened Quest to Train the Ideal Mate (New York: Basic Books, 2013), p. 53. 
as Butler has persuasively argued, with reference to Maria's correspondence and early fiction, Edgeworth seems to have been very much interested in Day's philosophical perspectives, so much so that her own publishing career and Day's became intertwined. Stephen Bending and Stephen Bygrave detail this intertwining with respect to the development of Day's incredibly popular novel for children, The History of Sandford and Merton (1783-9). They explain how,

Day's tale originated as a short story for inclusion in Harry and Lucy, a larger projected work for children planned by Day's friend Richard Lovell Edgeworth and Edgeworth's [second] wife Honora (Sneyd). Harry and Lucy (eventually given to R. L. Edgeworth's daughter Maria for Early Lessons, published in 1801) was, [according to Richard Lovell's Memoirs (1820) written by Maria], 'to have diffused through an interesting story, the first principles of morality, with some of the elements of science and literature, so as to show parents how these may be taught without wearying the pupil's attention.'. ${ }^{13}$

These publishing details reflect how Day and Maria's educational philosophies became increasingly entangled. Day's The History of Sandford and Merton is larded with controversial applications of its author's educational theories and beliefs as well as his standard denunciations of wealth and luxury, and Maria's celebration of Day's novel and the tale that inspired it in the 'Frank' story in Early Lessons (1801) testifies to her approbation of at least some of Day's intellectual and educational commitments. In 'Frank', Maria references Sandford and Merton in order to urge matching a child with content appropriate to his or her age. Specifically, she writes, 'the last volume of which is suited to young men at college; while parts of the first two are fit for children of seven or eight, and other parts for ten or twelve years old'. ${ }^{14}$

Maria Edgeworth's familiarity with Sandford and Merton must have certainly also included knowledge of its representations of Day's views of women's education, introduced through the character of Miss Simmons. When the spoiled and wealthy Tommy and his humble 'plough-boy' friend Harry visit the Merton home, complete with fashionable acquaintances, Miss Simmons provides a distinct counter to the behaviors of the elite set gathered there. ${ }^{15} \mathrm{We}$ learn that Miss Simmons, orphaned at a young age, was raised by her uncle, 'a man of sense and benevolence, but a very great humorist' (p. 249). She was

${ }_{13}$ Thomas Day, The History of Sandford and Merton, ed. Stephen Bending and Stephen Bygrave (Peterborough, OT: Broadview Press, 2010), p. 11.

${ }_{14}$ Edgeworth, Maria, Early Lessons, ${ }^{\text {nd }}$ edn., vol. 1. (London: J. Johnson, 1815), p. xiv.

${ }^{15}$ Day, The History of Sandford and Merton, p. 249. 
'taught to believe that domestic economy is a point of the utmost consequence to every woman that intends to be a wife or mother' (p. 250). As a result, Miss Simmons is able to provide measured and accurate moral judgment of such characters as 'Lord Squander'. She is also able to explain to Harry the hypocrisies of fashionable life, and, most importantly, she is able to read well and choose reading material appropriate to the entire group, regardless of age. Day's Miss Simmons is provided a practical education that perfectly suits her to carry out the duties of a domestic sphere.

In addition, Miss Simmons carries out this domestic duty by reinforcing female subservience. As such, she chooses to read the story of 'Sophron and Tigranes', about two Asian boys whose adaptation to the politically unstable and violent world around them take different forms (p. 250). ${ }^{16}$ Significantly, Miss Simmons's choice repeats her own unique educational history. In it, Sophron rescues an old man and his beautiful daughter from a party of soldiers who have taken them prisoner. When the old man, Chares, provides his history, he also includes the education of his daughter, Selene: 'As she grew up, her mother instructed her in all the arts and employments of her sex; while I ... thought it necessary to arm her mind with all the firmness which education can bestow' because, he insists, 'it is upon the qualities of the female sex that our own domestic comforts and the education of our children must depend' (p. 367). Finally, Chares explains how Selene also heard 'the lessons of wisdom and the examples of virtuous women, which I used to read to her at evening, out of the writings of celebrated philosophers' (p. 367).

It makes some sense then, in the context of Day's novel and Edgeworth's established familiarity with it, to read Edgeworth's 'Letter from a Gentleman' as a repetition of Day's conservative views of education. In Edgeworth's text, like in Sandford and Merton, the gentleman insists that 'having been educated in the amiable acquiescence to well established maxims of female prudence' is the most effective way of ensuring 'women be conducted quietly to their good'. ${ }^{17}$ The gentleman goes on to also remind his correspondent of the incompatibility of literary learning and the realities of running a home when he writes, 'I should not expect that my house affairs would be with haste dispatched by a Desdemona, weeping over some unvarnished tale, or petrified with some history of horrors, at the very time when she should be

${ }^{16}$ As Bending and Bygrave note in their edition, the source of this tale is likely Thomas Percival's A Father's Instructions; consisting of moral tales, fables, and reflections; designed to promote the love of virtue, a taste for knowledge, and an early acquaintance with the works of nature, seventh edition (1788) in which Sophron's tales are drawn from Oliver Goldsmith's History of the Earth and Animated Nature (1774).

${ }^{17}$ Maria Edgeworth, Letters for Literary Ladies, (London: Everyman, 1993), p. 6. All subsequent citations refer to the 1798 revision reprinted in Clair Connolly's 1993 edition, unless otherwise noted. 
ordering dinner, or paying the butcher's bill' (p. 12). This certainly seems to be Edgeworth's reification of Day's misogyny.

Any misogyny we see in Edgeworth's gentleman must be dismissed, however, upon closer reading of his letter; it decisively proves that no man's mere interest in women's education renders him suitable to make pronouncements upon it. The letter opens, 'I congratulate you, my dear sir, upon the birth of your daughter ... but we differ materially as to the cultivation which it is necessary or expedient to bestow upon the understandings of women' (p. 1). The argument following this is a perfect example of what Audrey Bilger identifies in Edgeworth's novels as her mocking of patriarchal texts by 'attributing sexist assumptions to comic male characters'. ${ }^{18}$ Bit by bit, her Gentleman correspondent betrays his own failure of duty, emotional excess, rational deficiencies, and tyrannical tendencies. Immediately, he reveals his tendencies toward superstition when he calls on the 'fairies of ancient times' to endow the infant with the 'health, wealth' and 'beauty' (p. 1) that would best prepare her for the 'domestic duties, taste for dissipation, love of romance, poetry, and all the lighter parts of literature' must 'so fully' occupy their time 'it seems impossible that their minds should ever acquire that vigour and efficiency, which accurate knowledge and various experience of life and manners can bestow' (pp. 2, 2, 3). His own reasoning skills are lazy, circular, and based on inaccurate observations of the world around him, and, as such, they render him completely unfit to rule upon the propriety of anyone's education, including that of the women he has so unjustly accused of this very behavior.

The gentleman's poorly constructed argument against women's wit continues by insisting on the inferiority of female intellect and the 'monstrous' offense that any exception to this rule has posed to his 'taste' (p. 1). But in the next breath his acknowledgement of the 'great talents' some women have displayed in 'poetry, plays, and romances, in the art of imposing upon the understanding by means of the imagination' proves that women's wit does indeed have value, albeit value derived from its power to manipulate his own weak mind, a power which further undermines his previous pronouncement on the essential non-relationship between women's wit and taste. Further, his insistence that 'women must always see things through a veil, or cease to be women' inadvertently acknowledges the very constructed nature of expectations for women's behavior by likening it to a garment that, by definition, may be donned or doffed at will (pp. 2, 3). In addition, his denunciation of the history of 'female influence and female depravity' in political history to maintain that no woman may be trusted with power, similarly betrays faulty reasoning, arguing that past description is sufficient for present prescription of women's behavior. This

${ }^{18}$ Audrey Bilger, Laughing Feminism: Subversive Comedy in Frances Burney, Maria Edgeworth, and Jane Austen (Detroit: Wayne State University Press, 1998), p. 119. 
cherry-picking of evidence also fails to acknowledge the necessarily similar and illogical outcome of applying such reasoning to historical examples of male influence and male depravity in political history. Perhaps most effective in Edgeworth's mocking of the gentleman's anti-feminist stance is his repeated equivocation of the essential terms of his argument when he says women must necessarily depend upon 'traditional maxims of experience, or those early prepositions, which may be termed prejudices, but which in reality serve as their moral instinct' (p. 31). In this formulation, the laws guiding behavior for women should be simultaneously those of experience and lack of experience and they should derive simultaneously from innate impulses and developed partialities. The only consistency in the gentleman's argument stems from his application of the previous premises to his circular questioning of the 'utility' of women's intellect to the 'useful arts'. At this point, Edgeworth's biography and her gentleman could be seen to render Letters the result of a personal grudge. Edgeworth might seem to merely attack Day and the most misogynist and conservative of his views without in any significant way adding to discussions of women's education.

Nevertheless, Edgeworth's gentleman also admits the possibility and importance of positive educational change for women that seem to go beyond domestic subservience. He allows: 'I should be glad to see a list of discoveries, of inventions, of observations, evincing patient research, of truths established upon actual experiment, or deduced by just reasoning from previous principles' (p. 3). Such emphasis on the empirical and rational in women's education, however, was also important to Day. Also in Sandford and Merton, Miss Simmons's education, in addition to its domestic utility, is described in more radical terms. We are told that Miss Simmons's uncle 'had such peculiar ideas of female character, that he waged war with most of the polite and modern accomplishments' (p. 249). This took the form of regular cold baths, daily early-rising, and lengthy horseback rides and walks regardless of weather. She was also instructed in 'several parts of knowledge, which rarely fall to the lot of ladies; such as the established laws of nature and a small degree of geometry' (p. 250). Her education had other limits as well. We read: 'As to music, though Miss Simmons had a very agreeable voice ... she was entirely ignorant of it. ... Nor would he permit her to learn French' (p. 250). Chares's description of his daughter's education in Miss Simmon's narrative is also unusual for the vigor and strength it promoted at the expense of more traditional accomplishments. Chares describes: 'I endeavored to give both to her mind and body a degree of vigor, which is seldom found in the female sex. As soon as she was sufficiently advanced in strength to be capable of the lighter labors of husbandry and gardening, I employed her as my constant companion' (p. 366). In addition, he believed in 'hardening [women's] minds by the severer principles of reason and philosophy'. Misogynist or no, science 
and vigor prove integral to Day's notions of women's education. These details illustrate the complexity of Day's text. On one hand, it champions reason and physical vigor instead of mere accomplishments. On the other, it relegates women's education to domestic instrumentality. Such complexity explains the subtlety of Edgeworth's engagement.

\section{Day and Wollstonecraft as Interlocutors}

Significantly, Day's misogynist and conservative notions may also be recognized as more truly radical. As D. L. Macdonald and Kathleen Sherf observed in their edition of Wollstonecraft's Vindication of the Rights of Woman (1792), Mary Wollstonecraft praised this very passage from Sandford and Merton and quoted it at length. She describes it as a 'sensible account' from a 'respectable old man' and reproduces Day's text including its justification:

If women are in general feeble both in body and mind, it arises less from nature than from education. We encourage a vicious indolence and inactivity, which we falsely call delicacy ... we breed them to useless arts, which terminate in vanity and sensuality. ... And what are the comforts or the education which a race of beings, corrupted from their infancy, and unacquainted with all the duties of life, are fitted to bestow? ${ }^{19}$

Macdonald and Sherf also note that this lengthy quotation also closes the review of the final volume of Sandford and Merton in the Analytical Review (September-December 1789), attributed to Wollstonecraft. Radical feminism and conservative misogyny converge in Wollstonecraft and Day.

Thus, while Cafarelli has argued that Wollstonecraft 'was by far the most radical feminist' of her contemporaries, including Maria Edgeworth, in Edgeworth's 1798 revisions to the text, she takes on both Wollstonecraft and Day. Specifically, in the Advertisement that emphasizes the revision's more radical feminist commitments Edgeworth writes: 'In the first edition, the Second Letter upon the advantages of cultivating the female understanding, was thought to weaken the cause it was intended to support. - That letter has been written over again; no pains have been spared to improve it, and to assert more strongly the female right to literature' (p. xxvi, emphasis added). Acknowledgement of this reworking is key, especially in combination with Susan Manly's important observation that the determination to revise was 'a remarkable decision considering that, with the same publisher as Mary

${ }^{19}$ Mary Wollstonecraft, The Vindications: The Rights of Men, The Rights of Women, ed. D. L. Macdonald and Kathleen Scherf (Peterborough, OT: Broadview Press, 1997), p. 152 n. 
Wollstonecraft and William Godwin - Joseph Johnson - she would have been well aware of adverse criticism of the kind of woman's literary life made public by Godwin through his memoirs of Wollstonecraft .... ${ }^{20}$ Edgeworth's presentation of the nature of women's rights is of particular importance. Invoking the language of the Vindications, the father writes:

Do not, my dear sir, call me a champion for the rights of woman; I am too much their friend to be their partisan, and I am more anxious for their happiness than intent upon a metaphysical discussion of their rights: their happiness is so nearly connected with ours, that it seems to me absurd to manage any argument so as to set the two sexes at variance by vain contention for superiority. It ought not to be our object to make an invidious division of privileges, or an ostentatious declaration of rights, but to determine what is most for our general advantage. (pp. 29-30)

Rather than effectually reinforcing a 'metaphysical' separate but equal law of reason to men and women as Wollstonecraft does in her Vindication of the Rights of Man and Vindication of the Rights of Woman, Edgeworth's father character demands that by enacting equal education for his daughter, he is enacting equal citizenship for men and women.

The evenhanded 'Answer to the Preceding Letter' throws into even starker relief the various absurdities of the gentleman's unreasonable prejudices, but it also allows for the propriety of men's participation in discussions of women's education. Countering the Gentleman's claim that learned women are necessarily imperious and unpleasant, Father recollects that 'A profusion of vulgar aphorisms in the dialects of all the counties in England, proverbs in Welsh, Scottish, French, Spanish, Italian, and Hebrew, might be adduced to prove that scolds are to be found amongst all classes of women' (p. 15). He then goes on to redefine the term as 'women who have cultivated their understandings not for the purposes of parade, but with the desire to make themselves useful and agreeable,' and he insists, 'I estimate the value of a woman's abilities and acquirements, by the degree in which they contribute to her happiness' (p. 16). Fortunately, for Father's daughter, 'women of literature are much more numerous of late than they were a few years ago,' providing a large potential circle of acquaintances and friends. Unmarried women, in particular, benefit from a rich education that ensures that 'by a variety of associations they are connected with the world, and their sympathy is expanded and supported' (p. 17). Father goes on to insist that since a happy

${ }^{20}$ Susan Manly, 'Maria Edgeworth and (Inter)national Intelligence' in A Companion to Irish Literature, vol. 1, ed. Julia Wright (London: Wiley-Blackwell, 2010), p. 278. 
marriage is not guaranteed for his daughter, 'it will be therefore prudent to make her felicity in some degree independent of matrimony' (p. 17). At length, Father reminds his friend of the changing values of their world. He creates an analogy between the recent recognition of 'men of deep science' and women who 'now possess a considerable stock of information' (p. 18, 19). He declares, 'You must have observed that public opinion is at present more favorable to the cultivation of the understanding of the female sex that it was some years ago,' so much so that 'something more is now required' of women (p. 19). He goes on to describe how Chemistry and Mathematics are more than appropriate areas of study for women's cultivation of 'social virtues' conducive to 'our own happiness or that of our fellow-creatures' (p. 22). He describes how good habits and power of reasoning are mutually reinforcing when cultivated in age-appropriate ways over the course of childhood and that such cultivation culminates on 'strength of mind which enables people to govern themselves by their reason' (p. 24). He describes women's reading as a better occupation than 'coquetting or gaming' and women's writing 'at least as good' as that of many men' (p. 25). Further, he writes: 'Far from being ashamed that so little has been done by female abilities in science and useful literature ... much has been effected. On natural history, on criticism, on moral philosophy, on education, they have written with elegance, eloquence, precision and ingenuity' (p. 27). Edgeworth's refinements of Day and Wollstonecraft are unmistakable.

Even more effective than Edgeworth's nuanced refutation of arguments against the propriety of literary women is her direct refusal of Day and Wollstonecraft's repetition of Day's specific instruction. Father insists on the importance of cultivating 'the general powers of the mind, rather than any particular faculty' (p. 20). He writes:

I do not desire to make my daughter merely a musician, a painter, or a poet; I do not desire to make her merely a botanist, a mathematician, or a chemist; but I wish to give her early the habit of industry and attention, the love of knowledge, and the power of reasoning: these will enable her to attend to excellence in any pursuit to which she may direct her talents (p. 20)

Significantly, this father invokes the standard accomplishments recommended to young women as qualities attractive to men in order to insist, instead, on women's ability to become masters, in their own right, of such skills. He then goes on to pair women's ability to master these frequently feminized skills with that of masculine natural sciences. Methodical study exploring a variety of topics contributes to the formation of a rational mind for women 
whose agency allows them to direct their attention and skill according to their own desires, not just marriage.

In addition, it is not until the last page that the Father addresses his friend's skepticism regarding the suitability of literary ladies to husbands, arguing that such women's observations are 'beneficial to her fellow-creatures', her writings reflect the belief that one 'who must depend so much as man does on the assistance of others, owes, as a debt to his fellow-creatures, the communication of the little useful knowledge that chance may have thrown in his way' (p. 37). This, Father writes, has been proven by the respectable example of Sir George Lyttleton, author of Dialogues of the Dead (1760) with Elizabeth Montagu; Albrecht von Haller, Swiss natural scientist and author of Letters from Baron Haller to His Daughter on the Truths of the Christian Religion (1780); and Dr. John Gregory, Scottish physician and author of Father's Legacy to His Daughters (1761). The strength of this reasoning and example, he assumes, must clearly answer his last rhetorical flourish, the letter's closing: 'Can women of uncultivated understandings make such wives or such mothers?' (p. 38). And while some have understood this emphasis as a reprisal of Maria Edgeworth's own father, Richard Lovell Edgeworth's, conservative progressivism, this question explicitly mirrors Mary Wollstonecraft's invocation in The Vindications of Thomas Day's conservatism. Important to note here, is how insignificant a role the question of educated women's suitability as wives and daughters plays in the father's overall argument. The last one sentence paragraph is a question that needs no additional reasoning or support; the answer is such a commonplace it requires no further discussion.

Edgeworth's deliberate engagement with Wollstonecraft's radical language becomes less remarkable, however, through close reading of the next portion of Letters, 'Letters of Julia and Caroline'. This portion of Letters juxtaposes the correspondence of two quite different women to illustrate that women were not, as a result of a superior natural physical sensitivity, more emotional and less rational than men; the letters also demonstrate that women do not possess more social sympathy. Julia's letter begins the collection and justifies her privileging feeling over principle as a result of the fact that 'a woman's part in life is to please' (p. 40). In response, Caroline insists that Julia's justification is contradictory, that she acts 'from principle' in cultivating 'slight accomplishments and a trivial character' (p. 43). With this foundation laid, the rest of the correspondence charts Caroline's advice to Julia upon her marriage to a Lord $\mathrm{V}$ - and the 'public diversion and public admiration, dissipation, and all the pleasure of riches and high rank' corresponding to it (p. 48). Caroline founds her argument upon the fact that a hectic public life is incompatible with 'the pleasures of the heart and of the imagination', 'cultivating literary taste', and 'friendship and confidence, or any of the delicacies of affection' that would render her 'equal' to her husband (p. 49). In contrast, Caroline 
recommends a more retired existence as the wife of her own brother, a life in which 'The regulation of your time and occupations would be your own' (p. 49). This is followed by another letter in which Caroline offers Julia advice regarding her desire to separate from her husband, Lord V- after five years of marriage. Citing Julia's self-described 'despair' at the 'madness' that led her to accept Lord V-, Caroline attempts to reason with Julia. She writes: 'Despair is either madness or folly. ... In strong minds, despair is an acute disease; the prelude to great exertion. In weak minds, it is a chronic distemper, followed by incurable indolence. Let the crisis be favourable, and resume your wonted energy' (p. 50). Her mind is neither necessarily weak or strong, feminine or masculine. Her actions will determine her suffering from the effects of ideas equally dangerous to all humanity. Further, in the next letter to Julia, written after her separation from Lord V-, Caroline reprimands her friend for playing the victim by declaring herself a being with 'no free will' (p. 56). Reiterating Edgeworth's critique of metaphysics found in the father's letter, Caroline writes:

Your understanding involved itself in metaphysical absurdity. In conversing upon literary subjects one evening, in speaking of the striking difference between the conduct and the understanding of the great Lord Bacon, you said, 'It by no means surprised you; that to an enlarged mind, accustomed to consider the universe as one vast whole, the conduct of that little animated atom, that inconsiderable part self, must be too insignificant to fix or merit attention. It was nothing', you said, 'in the general mass of vice and virtue, happiness and misery'. I believe I answered, 'that it might be nothing compared to the great whole, but it was every thing to the individual'.

For Caroline, the value of literature and reason lay in their ability to aid an individual's navigation of a complex universe, and part of that navigation must involve the recognition of humanity's essential moral difference from the rest of creation. Caroline's next letter traces her break from the now 'infamous' and 'fallen' Julia; in the last and final letter, Caroline writes to Lord V- to describe her reunion with Julia in which Julia has returned to beg, upon her deathbed, that her friend and daughter forgive her for her 'disgrace' (pp. 58, 62). Caroline writes, 'I think I never felt such sorrow as I did in contemplating Julia at this instant: she who stood before me, sinking under the sense of inferiority, I knew to be my equal - my superior; yet by fatal imprudence, by one rash step, all her great, and good, and amiable qualities were irremediably lost to the world and to herself' (p. 60). Here, Caroline acknowledges her own hardness of heart, her own cowardice in shunning her friend in her hour of need. She acknowledges Julia's superior qualities and their essential equality as women subject to the prejudice and judgment of others. Most importantly, Caroline 
also records Julia's last words to her daughter to 'be good and happy' (p. 62). Caroline does not equate women's intelligence with subservience to men, but she does acknowledge the ability of other men and women to judge a woman's goodness and thus her ability to be happy in their midst. For Edgeworth, in contrast to Wollstonecraft, good and right are more than metaphysical terms or abstract ideas; they are behaviors upon which intelligent women and men must determine to act upon according to their own potential for happiness.

The last piece in Letters, 'An Essay on the Noble Science of Self-Justification', ices the preceding layer cake of correspondences between men and women, rejecting any easy correlation between conservatism and radicalism in men's and women's views on women's education. Its first line attacks Day and Wollstonecraft directly by presenting a semantic argument: 'Endowed as the fair sex indisputably are, with a natural genius for the invaluable art of selfjustification, it may not be displeasing to them to see its rising perfection evinced by an attempt to reduce it to a science' (p. 63). This line immediately mocks any essentialist claims about women's natural intellectual or emotional abilities. But it also simultaneously links the Day/Wollstonecraft condemnation of the 'useless arts' practised by women to the question of useful arts or, in other words, sciences, through 'reduction'. The art of self-justification, otherwise known as deflecting blame, may be better understood as a science according to the observation that 'very little precept and practice will confirm [women] in the habit, and instruct them in all the maxims' of it (p. 63). This conflation of arts and sciences has led Connolly to read 'An Essay' as the 'return of repressed emotion, passion, and pleasure' denied in the two previous epistolary discourses (p. xxv). However, re-examination of 'An Essay's' rhetorical structure, in the context of the entire collection suggests that its particular contributions lie elsewhere than in the 'emotion' both the previous set of letters clearly contextualize according to women's intellectual equality. Instead, the progressive genius of Edgeworth's intervention lies in her specific deployment of Enlightenment discourse. In 'An Essay', she redefines the relationship of men and women to scientific rationalism, further undermining any easy relationship between women and reason and continuing to critique justifications for women's education grounded in the privileging of women's domestic duties.

Interestingly, in the advertisement for the second edition of the collection, Edgeworth draws a distinction between the first two sets of correspondence and the final essay, writing:

The first two letters upon Female Literature, the Letters to Julia, and the Arts of Self-Justification, were printed and paged separately: the publisher afterwards thought proper to join them in one volume, under the title of 'Letters for Literary Ladies', which is applicable only to the first letters. - The author, however, has thought it better to continue 
the former name, than to hazard the imputation of publishing an old work under a new title. ${ }^{21}$

With this notice, Edgeworth acknowledges that this edition speaks to a new audience, and, upon immediate consultation of 'The Essay', it becomes apparent that the intended reader is neither the kind of literary lady so maligned in the first set of correspondence by the Gentlemen nor the distinctly domestic literary lady so aptly defended by the father's and Caroline's letters. 'Only to the first letters' suggests that Edgeworth intended only the letters between the gentlemen for 'Literary Ladies'. Her ironic ventriloquizing of male arguments against women's education is a deliberate warning to women against the specious and fallacious arguments by which men continued to deny women reason. Nevertheless, the parody of both literary and unliterary ladies in the letters between Caroline and Julia that follow invalidates arguments for domestic duty as a justification for women's intellectual training and education. These letters, ostensibly for an audience of literary men, confront her readers with the potential for a particular literary lady, Edgeworth herself, to craft 'useful literature' outside of the confines of her own domestic duties as wife and mother.

The final essay of the text takes the form of a philosophical treatise that proves Edgeworth's ability, as woman, to craft this very kind of literature. In it she proves the ability of women to engage in reasoned debate, setting forth conclusions based on 'axioms' and 'principles' (p. 63). Her insistence on the value of establishing specific terms within any productive argument demonstrates her mastery of this practice. She writes:

Right and wrong, if we go to the foundation of things, are as casuists tell us, really words of very dubious signification, perpetually varying with custom and fashion, and to be adjusted ultimately by no other standards but by opinion and force. Obtain power, then, by all means: power is the law of man; make it yours. (p. 64)

In this moment, Edgeworth's simultaneous invocation of casuistry to provide an ironic imperative to tyranny acknowledges the arbitrary foundation of both patriarchy and metaphysical argumentation. Edgeworth further demonstrates her expert argumentative skills when she encourages her audience to consider audience needs and expectations. She explains how 'nicety of conscience' or moral sensitivity 'may be of use in your first setting out, because you must establish credit; in proportion to your credit will be the value of your future asseverations' (p. 68). She also outlines the usefulness of the Socratic method and 'interrogatories artfully put' (p. 72).

${ }^{21}$ Maria Edgeworth, Letters for Literary Ladies. $2^{\text {nd }}$ edn. (London: J. Johnson, 1798), pp. iv-v. 


\section{Women's Literary Networks and Romanticism}

Of course at odds with this demonstration of 'useful' women's wit, is the literal message of the 'Essay'. Repeatedly, it uses battle metaphors to describe matrimony referring to it as 'combat' and 'battle' and referring to a husband as 'that common enemy' (pp. 64, 65, 65). In addition, the narrator supplies specific instructions for how to subdue a husband with 'an active temper' by appealing to the subjective nature of 'taste' and the idiosyncrasy of 'manners' (pp. 65, 66). She goes on to recommend the efficacy of transferring blame to others (p. 67). With a 'sober-minded man' she recommends appearing to either concede, press ad nauseum, or 'suddenly grow absent' against any criticism (p. 69). These defensive strategies are opposed to those of the offensive type which include the conferral of 'obligations' on anyone who might help a wife's cause, muddying the issue with irrelevant questions, emotional appeals, and minute discernment of a husband's attitudes (p. 71). Collectively, this simultaneous well-informed philosophical dissection and detailed instruction in techniques of manipulation expose their faulty construction as 'natural' to women and of assuming the utility of all rational, philosophical, and scientific discourse.

Perhaps even more significant, however, is the different approach Edgeworth's narrator assumes near the end of the text. She explains:

Thus, my dear pupils, I have endeavoured to provide precepts adapted to the display of your several talents; but if there should be any amongst you who have no talents, who can neither argue nor persuade, who have neither sentiment nor enthusiasm, I must indeed - congratulate them; - they are particularly qualified for the science of Self-justification: indulgent nature, often even in weakness, provides for the protection of her creatures; just Providence, as the guard of stupidity, has enveloped it with the impenetrable armour of obstinacy. (p. 75)

Essentially, Edgeworth's narrator argues here, that even the most unlearned and irrational women may win the war of marriage, elevating personal power over moral virtue and duty. And by encouraging her pupils, during any marital dispute, to explain, 'No, my dear, you know I do not pretend to reason', she exposes the insufficiency of male wit to lead wives by reasoned example to domestic harmony and duty (p. 76). But, when the narrator finally concludes that these 'naturally' irrational women must win any matrimonial battle with their husbands 'even because they cannot conceive the excess of your stupidity, they shall actually begin to believe that they themselves are stupid', she insists on their superior intelligence and, thus, through insisting on the disastrous consequences of such marriages, further reinforces the equal importance of intelligence in both women and men should they become wives and husbands (p. 76). Ultimately, the 'Essay's' ironic discourse deconstructs arguments that, first, women must be inferior in reasoning to men and, second, that women's 
inferiority in reasoning aids in domestic duty. Edgeworth's satiric piece also deconstructs the argument that women's wit is necessarily either at odds with the fulfillment of women's domestic duty or must correspond to it.

Despite Edgeworth's troubled status in the canon of Romantic of women's writing, a status contingent upon her limited categorization as Anglo-Irish writer or writer of Children's literature, including disapproval of her supposed conservatism and paternalism, including unflattering claims about her apparently trying didacticism, Maria Edgeworth was undoubtedly the most successful, popular and respected authoress of her time. Letters for Literary Ladies exemplifies her first steps along this path and the thorough knowledge she had of her intellectual peers. Not only does it demonstrate her willingness to directly engage with both men and women writers of various political positions, it also illuminates her ability to shape their ideas and expectations for her own ends: the recognition and acclamation of women's intellectual equality regardless of social station or expectation. Stuart Curran, in his essay 'The Records of Woman's Romanticism' recently reviewed the history and present of recovery and analysis efforts. As a result of this review, he identified biography and publishing networks as important areas for future work, specifying: 'In a publishing industry constituted through the long eighteenth century by men for men, women had to inch their way into the business. Their access, if undoubtedly increasing markedly during the Romantic period, was in general on terms quite different from those of male writers'.22 Re-examination of Maria Edgeworth's biography and publishing networks, close reading of the allusions in her Letters, and re-examination of logical arguments presented within the various discreet portions of Letters as well as the text as a whole proves Edgeworth's active engagement with a publishing industry comprised of both men's and women's voices.

\section{Bibliography}

Bour, Isabell. 'What Maria Learned: Maria Edgeworth and Continental Fiction'. Women's Writing 18.1 (February 2001).

Bilger, Audrey. Laughing Feminism: Subversive Comedy in Frances Burney, Maria Edgeworth, and Jane Austen. Detroit: Wayne State University Press, 1998.

Butler, Marilyn. 'Edgeworth's Stern Father: Escaping Thomas Day, 1795-1801'.

Tradition in Transition: Women Writers, Marginal Texts and the EighteenthCentury Canon. Ed. Alvaro Ribiero and James G. Basker. Oxford: Clarendon, 1996.

—. Maria Edgeworth: A Literary Biography. Oxford: Oxford University Press, 1972. Cafarelli, Annette Wheeler. 'Rousseau and British Romanticism'. Cultural

22 Stuart Curran, 'The Records of Woman's Romanticism', Women's Writing 22.2 (2015), pp. 263-9, p. 266. 
Interactions in the Romantic Age: Critical Essays in Comparative Literature, ed. Gregory Maertz. Albany: State University of New York Press, 1998.

Connolly, Claire, ed. Letters for Literary Ladies by Maria Edgeworth. London: Everyman, 1993.

Curran, Stuart. 'The Records of Woman's Romanticism', Women's Writing 22.2 (2015).

Day, Thomas. The History of Sandford and Merton, ed. Stephen Bending and Stephen Bygrave. Peterborough, Ontario: Broadview Press, 2010.

Douthwaite, Julia. 'Experimental Child-Rearing After Rousseau: Maria Edgeworth Practical Education and Belinda'. Irish Journal of Feminist Studies 2.2 (December 1997).

Edgeworth, Maria. Early Lessons, 2nd edn. Vol. 1. London: J. Johnson, 1815.

—. Letters for Literary Ladies, ed. Clare Connolly. London: Everyman, 1993.

-. Letters for Literary Ladies, $2^{\text {nd }}$ edn. London: J. Johnson, 1798.

-. Memoirs of Richard Lovell Edgeworth, Esq., Vol. 2. London, 1820.

Gallagher, Catherine. Nobody's Story: The Disappearing Acts of Women Writers in the Marketplace, 1670-1820. Berkeley: University of California Press, 1995.

Kowaleski-Wallace, Elizabeth. Their Father's Daughters: Hannah More, Maria Edgeworth, and Patriarchal Complicity. New York: Oxford University Press, 1991.

Manly, Susan. 'Maria Edgeworth and (Inter)national Intelligence'. A Companion to Irish Literature. Vol. 1, ed. Julia Wright. London: Wiley-Blackwell, 2010.

Mellor, Anne K. 'A Novel of Their Own: Romantic Women's Fiction, 1790-1830'. The Columbia History of the British Novel, ed. John Richetti. New York: Columbia University Press, 1994.

Moore, Wendy. How to Create the Perfect Wife: Britain's Most Ineligible Batchelor and his Enlightened Quest to Train the Ideal Mate. New York: Basic Books, 2013.

Narain, Mona. 'A Prescription of Letters: Maria Edgeworth's "Letters for Literary Ladies", and the Ideologies of the Public Sphere'. Journal of Narrative Technique, 28.3 (Fall 1998).

Ó Gallchoir, Clíona. 'Gender, Nation, and Revolution: Edgeworth and de Genlis'. Women, Writing, and the Public Sphere, 1700-1830, ed. Elizabeth Eger, Charlotte Grant, Clíona Ó Gallchoir, and Penny Warburton. Cambridge: Cambridge University Press, 2001

Schroder, Anne. 'Going Public Against the Academy in 1784: Mme de Genlis Speaks Out on Gender Bias'. Eighteenth-Century Studies 32.3 (1999).

Toal, Catherine. 'Control Experiment: Edgeworth's Critique of Rousseau's Educational Theology'. An Uncomfortable Authority: Maria Edgeworth and Her Contexts, ed. Heidi Kaufman and Chris Fauske. Newark: University of Delaware Press, 2004.

Walker, Lesley. 'Producing Feminine Virtue: Strategies of Terror in Writings by Madame de Genlis'. Tulsa Studies in Women's Literature 23.2 (Fall 2004).

Wollstonecraft, Mary. The Vindications: The Rights of Men, The Rights of Women, ed. D. L. Macdonald and Kathleen Scherf. Peterborough, OT: Broadview Press, 1997. 
Chapter Nine

\title{
Mary Shelley and Sade’s Global Network
}

\author{
Rebecca Nesvet
}

On the evening of 7 August 1814, Mary Godwin (later Shelley), her lover Percy Bysshe Shelley and her stepsister Jane 'Claire' Clairmont set out from Paris to explore the French countryside. A seven-mile trudge brought them to the town of Charenton-St-Maurice. As Mary Shelley later wrote in her History of a Six Weeks' Tour (1817), Charenton was 'prettily situated in a valley through which the Seine flows, winding among banks variegated with trees'. Claire initially finds Charenton the best of all possible habitations. 'Oh! this is beautiful enough; let us live here', she begs. As 'every new scene [...] surpasse[s] the one before', she declares herself 'glad we did not stay at Charenton, but let us live here'. ${ }^{1}$

The sisters' observations seem particularly naïve because the valley's most prominent feature was neither the river nor the trees but the local mental hospital, which the Napoleonic regime had engaged to conceal certain not so beautiful aspects of French society. In 1814, the hospital housed several political provocateurs, against their will. One such patient was the naval surgeon, philosopher, and pamphleteer Victor Mariette (alias Victor Wreight). Another, the disgraced revolutionary Jacob Dupont, had attended the National Convention, where he preached atheism. ${ }^{2}$ But the most notorious of Charenton's political detainees was Donatien-Alphonse-François, Comte de Sade. At his death in December 1814, Sade's undesired stay at Charenton had lasted thirteen years.

${ }^{1}$ Nora Crook, gen. ed., Mary Shelley: Novels and Selected Works, 8 vols. (London: Pickering, 1996), vol. 8, pp. 19-20. This edition of Mary Shelley's works henceforth abbreviated NSW.

${ }^{2}$ Laure Murat, The Man who Thought he was Napoleon: Toward a Political History of Madness, trans. Deke Dusinberre (Chicago: University of Chicago Press, 2014), pp. 85-6; Joseph Berchoux, Le Philosophe de Charenton (Paris: Giguet and Michaud, 1803), p. 37. 
Was Mary Shelley's Charenton day trip her closest encounter with Sade, or did she also read his fiction? Critics have long doubted that she did. Mario Praz's seminal work of Romanticism, La carne, la morte e il diavolo nella letteratura romantica (1930), translated in 1933 as The Romantic Agony, claims that Mary Shelley named the Frankensteins' persecuted servant girl Justine, 'like Sade's unhappy virtuous heroine' only 'by an odd coincidence'. Praz finds the Justine imagery in Mary Shelley's Valperga equally accidental. 'All Mrs. Shelley did' for Sade's literary legacy 'was provide a passive reflection of some of the wild fantasies' invented by Percy Bysshe Shelley and Lord Byron, whom he assumes had in fact read Justine. ${ }^{3}$ In other words, Mary Shelley appropriated those men's knowledge of Sade's text, having none of her own.

Today, many scholars concur with Praz's assumption. D. L. Macdonald and Katherine Scherf's Broadview teaching edition of Frankenstein maintains that Byron and Percy Bysshe Shelley certainly read Sade, but Justine Moritz is only 'possibly named after the heroine of Justine' (emphasis mine). ${ }^{4}$ According to Wendy Steiner, 'we do not know whether Mary Shelley had in fact read Sade' (or Justine) but must assume that her husband or Byron did. ${ }^{5}$ Several other critics make the same statement in substantially similar language. ${ }^{6}$

I propose that Mary Shelley in fact had profound knowledge not necessarily of Justine, but of Sade's tale 'Eugénie de Franval', which concludes his multivolume compilation Les Crimes de l'amour (1800).7 A 'tragedy of incest' wherein an ancien régime libertine secretly seduces his own daughter, 'Eugénie de Franval' has been judged 'one of [Sade's] two or three best novella-length works'. ${ }^{8}$ I will argue that this tale anticipates many aspects of Mary Shelley's two earliest novels, Frankenstein and Mathilda: too many to be 'coincidental'. The 'Eugénie de Franval' character Monsieur Clervil anticipates Frankenstein's

${ }^{3}$ Mario Praz, The Romantic Agony, trans. Angus Davidson (London: Collins, 1962), p. 132.

${ }^{4}$ D. L. MacDonald and Kathleen Scherf, eds., Frankenstein (Peterloo: Broadview, 2002), p. 92 .

5 Wendy Steiner, Venus in Exile: The Rejection of Beauty in Twentieth-Century Art (Chicago: University of Chicago Press, 2002), p. 16.

${ }^{6}$ Julia V. Douthwaite, The Wild Girl, Natural Man, and the Monster: Dangerous Experiments in the Age of Enlightenment (Chicago: University of Chicago Press, 2002), p. 202; Anne Williams, 'Mummy, possest: Sadism and Sensibility in Shelley's Frankenstein', in Frankenstein's Dream', Romantic Circles: Praxis Series (July 2003), paragraphs 6 and 12; and Samuel Lyndon Gladden, Shelley's Textual Seductions: Plotting Utopia in the Erotic and Political Works (New York: Routledge, 2002), p. 39; Gladden cites MacDonald and Scherf (p. 92).

7 D. A. F. Sade, Les Crimes de l'amour, 4 vols. (Paris, 1800).

${ }^{8}$ Richard Seaver and Austryn Wainhouse, 'Foreword', The Marquis de Sade: The Complete Justine, Philosophy in the Bedroom, and other writings, trans. Richard Seaver and Austryn Wainhouse (NY: Grove 1965), p. xvi. Henceforth abbreviated CJ. 
Henry Clerval, while Mathilda can be read as a variation on 'Eugénie de Franval'.

Mary Shelley's participation in Sade's network of literary influence deserves critical attention in part because that network has long been assumed categorically to exclude women. Mary Shelley's reinventions of 'Eugénie de Franval' challenge the longstanding assumption that Sade's nineteenth-century global network of literary protégés was exclusively a gentleman's club. Her participation in this network deserves attention also because of its implications about her self-fashioning as an author and our understanding of her performance of gender, or, more specifically, of her performance of the role of the female reader and author among the Romantics.

\section{Sade's Global Network}

'I address myself only to those persons capable of hearing me', Sade once declared.' For much of his literary afterlife, Sade's successors have maintained that women do not 'hear' Sade, or else hear him in different ways than men do. A nineteenth-century myth maintained that any woman who read Sade's clandestinely-published works would become morally corrupt, prove herself destined to such corruption, or go mad. An indicative version of this myth appears in Frédéric Souliés novel Les Mémoires du Diable (1838), which in the 1840s was translated and serialized in the Illustrated Penny Novelist as a 'penny blood', or cheap fiction serial targeting working-class readers but read more widely..$^{10}$ In Les Mémoires du Diable, protagonist François Armand, Baron de Luizzi, voyeuristically watches a young woman imprisoned without any entertainment resources excepting one book. Boredom, it seems, forces her to read the book, alarming Luizzi once he sees its title: Justine, or, in Soulié's words, 'l'ouvrage immonde du Marquis de Sade, ce frénétique et abominable assemblage de tous les crimes et de toutes les saletés' ('The unclean work of the marquis de Sade, that insane and abominable conglomeration of all crime and filth'). Luizzi is immediately concerned for the female reader: not because she is imprisoned, but because she is apparently reading Sade. 'Cette jeune fille serait-elle un de ces êtres fatalement marqués pour l'infamie et le désordre?' ('That young girl, is she one of those beings fatally marked for infamy and derangement?' (88)). She proves she is not such a being by refusing to read Sade's text. Instead, she uses the white spaces on the printed pages to demonstrate her innocence by writing her own memoir, in her own blood. It

9 Donatien-Antoine-François de Sade, quoted in Anon., 'Publisher's Preface', CJ, p. xxi. I use the name 'Sade' rather than 'de Sade' by Sade's own preference, as expressed at the time of the French Revolution, when he declared himself a citizen.

${ }^{10}$ Frédéric Soulié, Les mémoires du diable [1838], 3 vols. (Paris: Michel Lévy Frères, 1888). 
is telling that both she and Luizzi apparently know Justine, by reputation if not from direct reading experience. The scene suggests that any sane woman cannot have read Justine. With this subtext, Soulié promotes the superstition that even though Sade's works are extremely difficult to access, the rare woman who obtains such access must resist reading.

Moreover, the Penny Novelist version suggests that it is the responsibility of those men (like himself) who do know Sade's work, at least by reputation, to limit access to it. In order to keep the English reading nation pure from Sadeian contamination, the Penny Novelist's translator censors Soulié, by omitting the title Justine and much of the description of that work quoted above. In the Penny Novelist text, Luizzi 'read[s] the title of the work, which he was horror-struck at finding to be one - , the reading of which proved how lost the being before him must be to every feeling of delicacy or horror. ${ }^{11}$ The knowledgeable disciple of Sade, already welcomed into his posthumous network of readers, would be able to fill in the translator's literal blank, while the typical, naïve reader would remain in the dark. In a novel whose plot turns on the supposedly malevolent influence of Sade upon female readers, the translator strives to acknowledge his own participation in Sade's network while keeping the uninitiated out of it. And, as we have seen, Soulie's superstition maintains that the uninitiated must include any sane, virtuous woman or girl.

Even today, literary-biographical tradition maintains that 'good' women recoil from Sade's fiction. Reportedly, Annabella, Lady Byron was 'horrified' to discover her husband's clandestine possession of a volume of Sade, and this discovery caused her to declare her husband mad - without her having read the book herself. This anecdote has been resoundingly discredited, but some modern biographers and scholars continue to advance it. Joshua D. Gonsalves (2006) argues that Lady Byron's 'horror' at finding Sade in Byron's 'secret hiding place' was not only a historical reality, but was a manifestation of her fear of 'conjugal sodomy'. ${ }^{12}$ The nineteenth-century proliferation of such superstition could not have encouraged either men or women to seek women in Sade's posthumous literary network.

Frequently in Sade's afterlife, he has played the libertarian martyr to decidedly female manifestations of censorship. This narrative makes his

${ }^{11}$ Memoirs of the Devil, by Frederick Soulie, Translated Expressly for the Penny Novelist, Chapter Six. The Penny Novelist and Library of Romance, n.s. 3, no. 16 (1842), 245-8, p. 247.

${ }^{12}$ Joshua D. Gonsalves, 'Byron - In-Between Sade, Lautréamont, and Foucault: Situating the Canon of "Evil” in the Nineteenth Century', Romanticism on the Net 43 (2006), par. 10. See also Piya Pal-Lapinski, 'Byron avec Sade: Material and Spectral Violence in Childe Harold's Pilgrimage Canto IV', Byron's Ghosts: The Spectral, the Spiritual, and the Supernatural (Liverpool: Liverpool University Press, 2013), pp. 131-46. Both these readings derive the anecdote from Benita Eisler, Byron: Child of Passion, Fool of Fame (New York: Knopf, 1999), pp. 39-40. 
posthumous network's lack of female readers a mark of his literary genius, and of the fine taste of the men who do appreciate his writing. This notion was promoted by one of the most zealous of nineteenth-century Sade aficionados, the Victorian poet Algernon Swinburne. Calling Sade 'the Martyred Marquis', Swinburne revered him. '[W]hat, indeed, do I not owe him?' Swinburne asked, and declared himself 'indebted' to Sade for 'whatever I have inadequately been able to express with regard to my sentiments toward God and Man'. Swinburne imagined a network of heroic Sade disciples oppressed by a hegemony which is explicitly characterized as female. According to Swinburne, 'the chains of the Goddess virtue' impede the wider reading public's recognition of 'the true worth of this Great Man'.13 The woman who fears Sade's effect on her sanity or reputation had morphed into Woman-ascensor of Great Men. In this myth, women did not read Sade because they could not recognize his genius. Their revulsion proves this genius, and that of the men who dare to explore it, like Swinburne.

Even after the poet-playwright Guillaume Apollinaire's 1909 attempt to reclaim Sade for the French literary canon, in part as a proponent of gender equality, prominent male keepers of the flame still claimed that Sade spoke primarily to male readers. They often made male-only lists of writers whom Sade influenced or who offered major evaluations of his work. Early in this tradition, Praz argued that the writers who flourished in 'the shadow of the Divine Marquis' were a global fraternity. He finds 'the Romantics [...] profiting by the theories of the Divine Marquis' on the operation of evil in the world (p. 125). '[T] he perverse Saint-Fond in Juliette spoke just like [Percy Bysshe Shelley's Count Francesco] Cenci', while 'the tortures described by Justine are of the kind which Sade's Justine suffered' (pp. 133-4). Praz also identifies Sadeian echoes in Percy Bysshe Shelley's The Sensitive Plant (p. 134) and contends that 'responsibility for the subject matter' of Jules Janin's L'Âne mort et la femme guillotine (The Dead Donkey and the Guillotined Woman) 'must be credited to [...] the Marquis de Sade' (p. 143). In Soulié, Praz finds another reluctant disciple, as Les mémoires $d u$ diable 'hinges upon the axiom', promoted by Sade, of the 'prospérités du vice and malheurs de la vertu' or the 'profits of vice and troubles of virtue', after Sade's summaries of Justine and Juliette's respective résumés (pp. 146-7). Gustave Flaubert's response to Sade was nothing short of 'obsession'; Praz reads Flaubert's Tentation as 'from beginning to end an orgy à la Sade', while Madame Bovary's interest in 'des livres extravagants ou il y avait des tableaux orgiaques avec des sitations sanglantes' ['outrageous books in which there are orgiastic scenes and bloody situations'] is 'an obvious allusion to Sade' (p. 171). While that is a convincing argument, Praz dismisses 'the same kind' of devil as

${ }^{13}$ Quoted in Richard Seaver, 'Foreword', in CJ, p. xviii. 
Soulié's Sadeian one 'in Mrs. Shelley's Frankenstein' (p. 147). Praz’s Sade's shadow covers only other men.

Praz's all-male Sadeian network-construction is hard to accept because it is possible that he never in fact read Sade. Only a year after the appearance of the English version, Geoffrey Gorer observed the 'extraordinary' identicality of all Praz's quotations from Sade's Justine and Juliette with those that appear in Georges Lafourcade's earlier (1928) monograph Swinburne's 'Hyperion' and other Poems, with an Essay on Swinburne and John Keats, and concluded that he was 'not certain' that Praz had actually read Sade. ${ }^{14}$ Praz apparently merely masqueraded as a member of Sade's network of influence. It is therefore particularly galling that in The Romantic Agony Praz argues that 'authoresses' are capable only of 'female imitativeness', not original literary achievement and that he declares not only Sade's posthumous Romantic-era network but the entire 'literary tradition' a 'monopoly of man' (pp. 112-13).

The male monopoly myth of Sade's network of literary influence grew throughout the twenty-first century. In 1935 Paris, Pierre Bataille and Pierre Klossowski founded the anti-fascist group Contre-attaque upon the principles of 'Sade, Fourier, and Nietzsche'. ${ }^{15}$ This platform envisions Sade within a network that includes both modern and historical male nodes, but no female ones. The writers who had belonged to Contre-attaque and their avant-garde compatriots produced a relative flood of scholarly responses to Sade, including Bataille's La valeur d'usage de D. A. F. de Sade (The Use Value of D. A. F. de Sade, 1930), Jean Paulhan's 'Le Marquis de Sade et sa Complice' ('The Marquis de Sade and his Accomplice', 1946), Klossowski's Sade ma prochain (Sade my Neighbour, 1947), and Maurice Blanchot's Lautréamont et Sade (1949). Some of these works were first printed as part of the critical apparatus of new Sade. Uniformly, the authors tend to see Sade's global network of influence as an all-male one. Paulhan declares that Sade was the 'favourite reading' of Alfred de Lamartine, Charles Baudelaire, Swinburne, Barbey d'Aurevilly, the 'Comte de Lautréamont' (pseudonym of the Uruguayan poet Isidore Lucien Ducasse), Friedrich Nietzsche, Fyodor Dostoevsky, Franza Kafka, and 'on a slightly different plane', Leopold von Sacher-Masoch and Octave Mirbeau. All these writers, of course, are men. Moreover, Paulhan imagines his readers including the next generation of Sade-inspired cultural provocateurs - as men only. 'Not only does [Sade] invite us to slay our neighbours and our parents', Paulhan maintains, 'he would have us kill our own wives. ${ }^{16}$ In 1950s France,

${ }^{14}$ Geoffrey Gorer, The Revolutionary Ideas of the Marquis de Sade (London: Wishart, 1934), p. 101.

${ }^{15}$ Romana Bynes, Aesthetic Sexuality: A Literary History of Sadomasochism (London: Bloomsbury, 2013), pp. 91-2.

${ }^{16}$ Jean Paulhan, 'The Marquis de Sade and his Accomplice', CJ, pp. 3-36, (pp. 3-4 and 6). 
the only readers who might have 'wives' are men, so Paulhan clearly imagines the readers of his Sade essay as a gentlemen's club - or a perverse double of the Académie, to which Paulhan belonged.

Also appearing in 1951 was Simone de Beauvoir's monograph Faut-il brûler de Sade? (Must we burn de Sade?). In this work, de Beauvoir argues for Sade's universality with respect to reader gender, but also fashions herself as an exception to the rule that Sade speaks only to men. 'No one', she claims, 'has emphasized with more vigour the link between the imagination and what we call vice, and he gives us, from time to time, insights of surprising depth into the relation of sexuality to existence. He also gives de Beauvoir a rhetorical scenario wherein she can contrast herself with the typical woman and especially the typical wife. 'It was through Renée-Pelagie', Sade's embattled wife, that he 'came to know all the insipidity and boredom of virtue', de Beauvoir claims. ${ }^{17}$ Her affirmation that virtue is boring suggests that she agrees this is also a risk of 1950s female notions of female 'virtue'.

Recycling the Swinburnian stereotype of the Divine Marquis scourged by female hypocrisy, de Beauvoir enlists Sade to work out some of her own issues about her place as a woman in her predominantly male avant-garde community. Having disparaged Sade's wife, she also concedes that this woman was 'not his enemy, but a choice victim, a willing accomplice' - as was de Beauvoir herself to her lover Jean-Paul Sartre when she lost her job at a lycée for recruiting schoolgirls as his sexual conquests. The book even seems most autobiographical when it is most fixated upon the minute details of Sade's life, for instance in de Beauvoir's meticulous, didactic 'Table of Women with Whom the Marquis de Sade Has Sexual Relations and Whose Names Have Been Recorded'. Many entries try to diminish his responsibility by dehumanizing these women: the data for the 'vocation' column includes 'Ladies of Easy Virtue' and 'Beggar' and noticeably does not include his sixteen-year-old mistress Madeleine Leclerc, whom he apparently met at Charenton, where she worked. ${ }^{18}$

Elsewhere in De Beauvoir's monograph, her Sade seems a double of Sartre. 'Madame de Sade fostered the intrigue between her sister and the Marquis' she claims, 'lent her support to the orgies at the Chateau of La Coste', and 'even went so far as to inculpate herself' while he 'never displayed the least gratitude' (p. 20). De Beauvoir's Sartre, like her Sade, is a 'Martyred Marquis': surely sadistic, but also a philosophical genius on the right side of history. Her treatment of Sade and Madame de Sade sheds light on the kinds of cognitive acrobatics that a mid-twentieth-century woman in the Parisian avant-garde community had to perform to be accepted, and to accept herself.

${ }^{17}$ Simone de Beauvoir, Must we burn de Sade? trans. Annette Michelson (London: Peter Nevill, 1953), pp. 11-19, 55.

${ }^{18}$ Ronald Hayman, Marquis de Sade: The Genius of Passion (London: Tauris, 2003), p. 223. 
Even after Faut-il brûler de Sade, critics tended to maintain the idea of an all-male Sadeian network. In 1952, the regular New Yorker contributor Edmund Wilson objected to Heine and Gorer's whitewashing (as Wilson saw it) of Sade's crimes, claiming that in their narrative, Sade was 'a courteous and considerate gentleman [...] persecuted by vulgar harlots' for his original thought..$^{19}$ Gorer defended this view, in a 1953 instalment of the New Yorker regular feature aptly titled 'Department of Amplifications. ${ }^{20}$

In the 1960s, when Sade's works were published above ground in English translation for the first time in history, the anonymous Grove Press 'Publisher's Preface' (1965) argued for Sade's significance on the grounds that Andre Breton, Paulhan, Blanchot, Klossowski, de Beauvoir, and Maurice Nadeau considered Sade 'a writer of the first importance, and one that must be taken very seriously'. ${ }^{21}$ Again, all the authors listed excepting de Beauvoir are men. Finally, it is notable that despite being billed as the 'first complete English translation of representative works by the Marquis de Sade', the Grove Press edition is not in fact complete because it omits the epigraph of La philosophie dans le boudoir: 'La mère en prescrira la lecture à sa fille'. ('The mother will assign this reading to her daughter'). ${ }^{22}$ Although obviously facetious, a burlesque of the conduct literature of his time, this epigraph was censored by the very editors, translators, and publisher who celebrated themselves for defying over a century of earlier censors. What in that sentence so unsettled them that they would compromise the accuracy of their work by its removal?

What happened when women tried to insinuate themselves into Sade's posthumous network of disciplines? An answer to this question was provided by the journalist and novelist Anne Desclos, Paulhan's lover, who under the pseudonym Pauline Réage, wrote the erotic novel L'histoire d'O. (1954). The rhetorical exigency to which Desclos responded in creating L'bistoire d'O. was Paulhan's insistence that no woman could write an erotic novel like those of the Marquis. She proved him wrong, and made it clear that her triumph was a reinvention of Sade's Justine and Juliette. Repeatedly avowing Sade's influence, l'Histoire 'knowingly combines the viewpoints of the hapless victim Justine and her vice-embracing sister Juliette' and is 'in any case, highly Sadeian'. Further linking L'histoire d'O. with Sade, it was first published by Jean Pauvert, Sade's modern publisher and biographer. As

${ }^{19}$ Geoffrey Gorer, The Marquis de Sade: A Short Account of his Life and Work (London: Liveright, 1934); Edmund Wilson, 'The Vogue of the Marquis de Sade' (1952), The Bit Between My Teeth: A Literary Chronicle of 1950-1965 (New York: Macmillan, 1965), p. 161.

${ }^{20}$ Geoffrey Gorer, 'Department of Amplifications', The New Yorker (10 January 1953), pp. 76-9.

21 'Publisher's Preface', $C J$, p. xix.

22 Donatien-Antoine-Francois Sade, La Philosophie dans Le Boudoir, Ouvrage posthume de l'Auteur de Justine. 'London' (N.P., 1795), title page, Gallica. Accessed 1 August 2016. 
Pauvert's publication of Sade was the subject of a sensational 1956 censorship trial, he was thereafter strongly associated with Sade's writing. ${ }^{23}$ Nevertheless, the Sade canon-building sources mentioned above, from Fowler to Seaver and Wainhouse to Paulhan himself, failed to include Réage in any of their lists of Sade protégés.

One reason why Réage had to be scrubbed from the network by the very men who invited her into it is suggested by Paulhan's comrade Blanchot. Claiming that Rousseau's critique of Justine (itself a knowing burlesque of Rousseau's own Julie, ou la Nouvelle Hélôise) included the assertion that '[a]ny girl who reads a single page of this book will be lost', Blanchot declared that Rousseau was paying Sade a great, if unintentional, compliment, and that '[s]uch respect is indeed a great treasure for a literature and [French] civilization'. ${ }^{24}$ When the cultural worth of a work of literature can be judged by its power to do mental and social violence to women, how can women be allowed to read, appropriate, reinvent, or critique it in the light of day?

The terms of Sade's late twentieth-century achievement of high-cultural status excluded him from regions of the emergent academic feminist community. The Sade scholar Jane Gallop has revealed that in 1977, when she was a graduate student on the job market, a 'feminist professor' asked Gallop during a campus interview 'how a feminist could work on Sade'. Gallop 'was able to give no coherent answer', but one answer might be that, like de Beauvoir, Gallop needed to join the Sadeian global network in order to join the gentleman's club of mid-century academia. ${ }^{25}$ She thought of her early publication on Roland Barthes and Sade as 'BS', after 'the clever sort of disinterested intellectual play which I thought I needed to get published' - a prerequisite for club membership (p. 12).

Gallop also formulated her major argument about Sade in terms that will seem very familiar: she relates him to several male literary inheritors, analyzing them as a network, in her monograph Intersections: A Reading of Sade with Bataille, Blanchot, and Klossowski (1981), published in the year that Andrea Dworkin declared Sade 'the world's foremost pornographer. ${ }^{26}$

${ }^{23}$ Elisabeth Ladenson, 'Literature and Sex', in The Cambridge Companion to French Literature, ed. John Lyons (Cambridge: Cambridge University Press, 2015), pp. 222-40, (p. 238). For an extended discussion of Pauvert's presentation of Sade and the obscenity trial, see Matthew Bridge's Ph.D. dissertation A Monster for our Times: Reading Sade Across the Centuries (Columbia University 2011).

${ }^{24}$ Maurice Blanchot, 'Sade', CJ, pp. 37-72, (p. 38). The trial is the major focal point of the dissertation.

${ }^{25}$ Jane Gallop, Thinking Through the Body (Columbia University Press, 1988), p. 2.

${ }^{26}$ Jane Gallop, Intersections: A Reading of Sade with Bataille, Blanchot, and Klossowski (Lincoln: University of Nebraska Press, 1981); Andrea Dworkin, Pornography: Men Possessing Women (London: The Women's Press, 1981), p. 70. 
Gallop concentrates on the triumvirate of Bataille, Blanchot, and Klossowski because they have been 'influential in shaping a contemporary reading of Sade' (p. 1). Overall, Gallop explicitly credits only men with responsibility for Sade's literary rediscovery. '[I]n our century', she insists, 'Sade has returned to circulation in society, thanks to the efforts of men such as Guillaume Apollinaire, Maurice Heine, and Gilbert Lély' (6, emphasis mine). However, by 1981, Sade was 'returned to circulation' in part by women including de Beauvoir, Must we Burn de Sade's translator Annette Michelson, the prolific translator Margaret Crosland, and Carter. ${ }^{27}$ None of these women, nor Réage, appears in Gallop's index, and where female thinkers are mentioned, their names are omitted. Instead, a personified, monstrous, 'France' has rather maternally 'produced' a 'deconstructive' feminism, 'daughter of antihumanism' (p. 2).

To some extent, Gallop's exclusion of women's names from Sade's network serves a part of the thesis of Intersections, which is that Sade's posthumous network models the 'fraternit[ies]' of 'friends' that populate his stories. 'Such is the Sadian libertine fraternity: underground [...], underhanded, and sneaky', while 'such is the textual network Bataille-Blanchot-Klossowski' (p. 115). Gallop claims that Intersections is 'intertextual' because it 'does not respect textual frontiers' (p. 1), but in this early, critical stage of her career, she knew that she had to respect the boundaries of gender when writing about Sade and his posthumous network.

This principle was reinforced two years later in Richard Gilman's New York Times review of Carter's groundbreaking 1978 monograph-manifesto The Sadeian Woman: An Exercise in Cultural History, which argued that Sade's writing can serve feminist ends, an idea initially advanced by Apollinaire. ${ }^{28}$ Gilman starts with a massive generalization about the difficulty of writing well about 'pornography', which is the genre - the only genre - in which he locates Sade's works. 'It's extremely difficult', Gilman opines, 'to maintain a disinterested, reflective attitude toward imaginative work whose chief, indeed only, purpose is to cause sexual excitation'. Very few scholars of Sade would find this the only purpose of his work - or even an effective rhetorical goal in his work. However, according to Gilman, 'Miss Carter's [...] radical positions tend to injure both scholarship and clarity of thought', so that she 'misun-

${ }^{27}$ Crosland's translation and editing work on Sade published prior to 1981 includes The de Sade Quartet: Four Stories from the Contes et Fabliaux (London: Peter Owen, 1963 and Panther, 1967) (with Gilbert Lély) Selected Letters (New York: October House, 1965, 1966), Selected Writings (London: Owen, 1964), 'Eugenie de Franval' and Other Stories (London: Neville Spearman, 1965 and Panther, 1968), and The Mystified Magistrate (London: Owen, 1963).

${ }^{28}$ Angela Carter, The Sadeian Woman: An Exercise in Cultural History (London: Virago, 1979); reprinted in the United States in the same year as The Sadeian Woman and the Ideology of Pornography. 
derstands the nature of [Sade's] enterprise'. Specifically, '[l]ike so many other writers on the subject, she clearly hasn't read enough pornography to know that within its obviously circumscribed intention it's as various as any other form of expression'. ${ }^{29}$ How much pornography Carter had read is not clarified in any of her works, so Gilman's hypothesis is purely hypothetical. Certainly, she read a great deal of Sade, and she wrote fiction that has been considered pornographic, or at least very sexually explicit, with sex as its major theme, in her short story collection The Bloody Chamber (also 1979). The implication of the New York Times review is that 'Miss' Carter can't be the sort of connoisseur of pornography that Sade's previous, primarily male scholars and disciples have been.

While some modern writers do admit that women can and wish to read Sade, this belief does not necessarily imply that women can join his network as original writers in their own right. A case in point is Doug Wright's powerful stage play Quills (1995), which is most widely known from its 2000 film adaptation directed by Phillip Kaufman and starring Geoffrey Rush (as Sade), Joaquin Phoenix, and Kate Winslet. In the play Quills - a modern grandguignol parable with no pretensions whatsoever to historical accuracy, or even historical romance - Madeleine Leclerc (Winslet, playing her considerably older than sixteen) and her elderly mother voraciously read Sade's (Rush's) fiction as he scribbles away in his Charenton cell. To Wright's credit, he argues that these two women have the capacity to read Sade without going mad or bad. However, they only receive and transmit Sade's works verbatim: they never adapt, respond, or reinvent. Madeleine makes this clear when she characterizes herself and her mother's role in relation to literature as audience alone. 'Mother and I, we're weak with boredom', Madeleine complains to Sade. 'For awhile, I smuggled home old newspapers from the scullery and read their accounts of the Terror. She found those too barbaric and pined for your stories instead'. 30 Madeleine and her mother earn limited membership in Sade's network, as they do not participate as creative writers or critics.

Because of this limitation, Madeleine and her mother play a more marginal role in Sade's network of literary influence than the play's male characters: the censors who provoke particular literary responses from him, the progressive cleric whose interaction with Sade ultimately causes him to write stories himself, and a telephone-tree chain of male patients, including a pyromaniac and a rapist-murderer. This network of male prisoners manages to twist one of Sade's stories into a new form, via misprision and conscious revision. Specifically, their misprisions of his story, which he dictates to them so they will pass

${ }^{29}$ Richard Gilman, 'Position Paper', The New York Times, 29 July 1979, nytimes.com/ books/98/12/27/specials/carter-sadian.html, retrieved 28 July 2016.

${ }^{30}$ Doug Wright, Quills and Other Plays (New York: Faber, 2005), p. 211. 
it on to Madeleine, alter the plot until it seems to the final, deranged inmate, the order to commit murder for which he has long been waiting. In contrast, neither Madeleine nor any other female audience member makes any original contribution to Sade's literary tradition.

Such exclusion of women from the imagined network of Sadeian literary influence also persists in twenty-first-century scholarly writing. While the contributions of twentieth-century literary critics, bibliographers, translators, and biographers of Sade are undeniable, some critics still imagine Sade's network of creative protégés as entirely male. As late as 2006, Joshua D. Gonsalves analyzes a mini-network made of Sade, Lautréamont, and Foucault, which he terms the 'canon of evil'. Gonsalves speaks of one Sadeian literary inheritor as a 'son of Sade' - which linguistically recalls the 1970s serial killer David Berkowitz, the self-styled 'Son of Sam', who murdered mainly women and was indignant at being labeled what he called a 'women [sic] hater'. ${ }^{31}$ Gonsalves calls for further examination of Sade's wider 'underground network' of literary influence, but does not discuss any women as possible nodes (par. 2).

This notion of an all-male global Sadeian network, underground or otherwise, is seriously complicated by the literary history of the Romantic era. One of Sade's earliest major interpreters, far predating Lautréamont and Swinburne, was a female novelist, Charlotte Dacre, alias 'Rosa Matilda'. As Adriana Craciun's research persuasively argues, Dacre appropriates content from Sade's La Nouvelle Justine (Justine and Juliette) in her novels Zofloya (1806) and The Passions (1811). Dacre does this, Craciun explains, 'to configure a more complex relationship between women writers and "masculine" discourses'. Consequently, Craciun insists, we must 'read' Dacre as part of the 'ostensibly male [...] tradition of pornographic and sensationalist literature', to understand 'her fatal women figures and her focus on corporeal pleasure and destruction.'.32 Dacre not only joined Sade's global network of influence, she wanted her readers to know it.

${ }^{31}$ Orit Kamir, Every Breath You Take: Stalking Narratives and the Law (Ann Arbor: University of Michigan Press, 2001), p. 144.

32 Adriana Craciun, Fatal Women of Romanticism (Cambridge: Cambridge University Press, 2003), pp. 130, 111-14. 


\section{Mary Shelley}

So, too, I will argue, did Dacre's near-contemporary Mary Shelley. The persistent representation of Sade's global network of influence as all male makes it vital to examine whether Mary Shelley's Sadeian allusions, like Dacre's, are based upon direct knowledge of his work. I will first determine whether the Shelleys could have obtained and read any of Sade's works, a question that previous scholarship has not entirely resolved. Sade's Justine was not published in English until Cannon's translated edition of 1830, and 'Eugénie de Franval' was not translated in Mary Shelley's lifetime. Like my predecessors, I have found no positive evidence of the Shelleys' ownership or borrowing of Sade. However, Mary Shelley had the necessary French-language knowledge and together, the couple belonged to relevant publishing networks; their members had access to Sade's works and similarly controlled literature, and the opportunity or motive to share them with the Shelleys. Mary Shelley's reading lists, recorded in her diaries of 1814-17, prove her able and willing to read French prose in the original. This documented reading included Voltaire's Mémoires and Candide, the Countess de Genlis's Adèle et Théodore; ou lettres sur l'education, Jean-Jacques Rousseau's Confessions and Rêveries $d u$ promeneur solitaire, Germaine de Staël's Corinne, ou l'Italie, and several novels by 'Madame de Souza' (Adélaïde-Marie-Emilie Botelho, Countess de Sousa), including Sénage, ou lettres de Lord Sydenham, and Eugénie et Mathilde, ou les mémoires de la famille du Comte de Revel. This last title's presence in Mary Shelley's reading list is notable because while nothing of Eugénie et Mathilde's content reappears in Mathilda, the title might have led Mary Shelley to freeassociate the name 'Eugénie' to Sade's heroine and then back to 'Mathilde' ('Mathilda'). In any case, Mary Shelley's copious francophone reading indicates she could have comprehended Sade's jargon-free prose had she been able and willing to access it.

I believe she was able and willing. She admitted that she read controversial and sometimes obscene French literature. Her catalogued reading includes the memoirs of the National Convention Président and Directory member Lazare-Nicolas-Marguerite, Comte de Carnot, and also Girondin and libertine Jean-Baptiste Louvet de Courvay's two major works: a memoir of his persecution by the Jacobin faction, and the fictional Aventures du chevalier de Faublas. Mary Shelley's father William Godwin also read Louvet's memoir, in 1795, 1796, and 1832.33 Byron evidently had a copy of the Aventures and incorporated aspects of it in Don Juan, and it was popular enough in Britain

33 William Godwin's Diary, godwindiary.bodleian.ox.ac.uk/index2.html. Accessed January 2015. 
for the first English translation to appear in $1822 .{ }^{34}$ In fact, in England, Faublas made Louvet's name as synonymous with obscenity as Sade's. The poet Anna Laetitia Barbauld implies as much in her treatise 'On the Origin and Progress of Novel-Writing'. In this essay, Barbauld insists that no English female should 'have her mind contaminated with such scenes and ideas as Crébillon, Louvet, and others of that class have published in France. ${ }^{35}$ Barbauld does not mention Sade, but she does not need to, as Louvet and Claude-Prosper Jolyot de Crébillon both notoriously published sexually explicit prose with radical political messages.

In France, this genre was called the livre philosophique; it began with Thérèse Philosophe (1748), but in nineteenth-century England had begun to be classed as what we would now call pornography. Clairmont alludes to the livre philosophique genre by calling herself and the Shelleys 'Otaheitian philosophers': that is, dogmatically promiscuous people. The same reading might apply to her Victorian recollection that during the Shelleys' private rendezvous in St Pancras Churchyard in 1814, they got rid of her on the grounds that they wished to speak 'on philosophical subjects' that she would not understand. These references combine with Mary Shelley's reading of Louvet's Faublas to imply that her coterie was familiar with 'that class of literature' that by 1814 Sade exemplified. ${ }^{36}$

Unlike most Regency women, Mary Shelley belonged to a literary network in which precisely that class of literature circulated. As Ian McCalman, Lynn Hunt, and Robert Darnton have demonstrated, a multigenerational network of French authors and their French and British publishers, translators, editors, and pirates produced politically subversive and sexually explicit writing, often of French origin, and often with the sexual imagery underscoring philosophical innovation or political critique. ${ }^{37}$ In January 1815, the Shelleys received together - a visitor from one of this network's most prominent publishers,

34 William St. Clair, The Reading Nation in the Romantic Period (Cambridge: Cambridge University Press, 2004), p. 677.

35 Anna Laetitia Barbauld, 'On the Origin and Progress of Novel-Writing', in Selected Poetry and Prose, ed. William McCarthy and Elizabeth Kraft (Peterloo: Broadview, 2002), pp. 377-416, (p. 414).

${ }^{36}$ Claire Clairmont to Lord Byron, 6 May 1816, quoted and discussed in William St. Clair, The Godwins and the Shelleys: the Biography of a Family, 1989 (New York: Norton, 1991), p. 404 and, more extensively, in Deirdre Coleman, 'Claire Clairmont and Mary Shelley: Identification and Rivalry within the "tribe of the Otaheite philosopher's" [sic]', Women's Writing 6:3 (1999), pp. 309-28. Janet Todd discusses the 'talk' in Death and the Maidens: Fanny Wollstonecraft and the Shelley Circle (London: Bloomsbury, 2013), pp. 129-30.

${ }_{37}$ Robert Darnton, The Forbidden Best-sellers of Pre-Revolutionary France (New York: Norton, 1996), p. 87. See also Lynn A. Hunt, The Invention of Pornography: Obscenity and the Origins of Modernity, 1500-1800 (Cambridge, MA: MIT Press, 1993), p. 117. 
George Cannon, who published Justine in 1820s London. Percy Shelley had read Cannon's publications since 1813, and Cannon printed Shelley's 'Queen Mab' and 'A Refutation of Deism' in his vehemently atheist magazine the Theological Inquirer. Mary Shelley may have had her own ties to him, as her father received visits from him earlier in the same month. In fact, Percy Shelley's most recent biographer, James Bieri, speculates that Godwin may have introduced him to Cannon. In any case, during Cannon's call on the Shelleys, they accepted 'papers' from him. What those 'papers' contained has not been ascertained, but the incident demonstrates Cannon's trust in the Shelleys and his collaboration with Percy Shelley. Later, in the 1820s, Cannon demonstrated access to Sade. He quit printing financially ruinous political prose and concentrated on what we would now call pornography - including Sade's Juliette. According to the critic Ian McCalmain, Cannon 'managed to get literary contributions from [both] the Shelleys'. At some point, he also obtained Sade's work, and in 1815, the Shelleys had access to him, so he might have been able to provide them with copies of Sade. ${ }^{38}$

She had reasons not to admit this, however. As a teenager, Percy Shelley had composed sexually explicit horror fiction - Zastrozzi (1809) and St Irvyne, or the Rosicrucian (1811), apparently for the entertainment of his eldest sister and his intended wife Harriet Grove - and later dismissed it as a juvenile mistake. ${ }^{39}$ In an 1812 letter to Godwin, he repudiates Zastrozzi as a 'distempered tho' unoriginal vision' and attributes both compositions to a 'state of mind' he has since outgrown. He also repudiated would-be publishers of his own work when they printed the wrong sort of livres philosophiques by others. He calls Cannon a 'vile beast' whom it is 'disgusting to see [...] talk of philosophy' (quoted in McCalman, p. 80). Richard Carlile, trained in printing by Thomas Paine and the Baron d'Holbach's London publisher Daniel Eaton, also published sexually explicit fiction. In 1819, Carlile asked Percy Shelley to allow him to reprint Queen Mab. The poet refused Carlile the rights, and Carlile printed Mab anyhow. In this domestic context, Mary Shelley would have had ample reason to abstain from citing the prime example of 'that class of literature' - Sade.

Of Sade's works, the Crimes de l'amour, the collection containing 'Eugenie de Franval', might have seemed the least repugnant to her household and society. The only work of prose fiction that Sade published under his own

38 Iain McCalman, Radical Underground: Prophets, Revolutionaries, and Pornographers in London, 1795-1840 (Cambridge: Cambridge University Press, 1988), pp. 80-1, 215; James Bieri, Percy Bysshe Shelley: A Biography: Youth's Unextinguished Fire, 1792-1816 (Cranbury, NJ: Rosemont, 2006), p. 347.

39 Percy Bysshe Shelley to William Godwin, 10 January 1812, quoted in Teddi Chichester Bonca, Shelley's Mirrors of Love: Narcissism, Sacrifice, and Sorority (Albany: SUNY Press, 1999), p. 24. 
name, it contains no stereotypically Sadeian obscenities: no detailed violence nor gymnastic sexual mise-en-scènes, no catalogues of supernumerary victims, no digressions into atheist rhetoric or anti-authoritarian political philosophy, and no erotic engravings. Its preface 'L'Idée sur le romans' ('The Idea of the Novel') is 'a prescriptive blueprint for the perfection of the [novel] genre' specifically, as the livre philosophique. It 'boldly lays out a theoretical defense of Sade's characteristic inversion of Pierre-Daniel Huet's standard of instruction for the novel to depict "la vertu couronné et le vice puni", or 'virtue celebrated and vice punished'..$^{40}$ The 'Idée', argues Katherine M. Astbury, is 'a classic eighteenth-century "homme de lettres" exercise allowing the would-be man of letters to show how the novel is an enlightened form'; his predecessors in this genre include Marmontel and de Staël, and Sade emulates de Stäl's 1800 essay De la littérature. ${ }^{41}$

The interior tales of Crimes were also somewhat easily mainstreamed. Sade himself adapted one story, 'Ernestine', as a stage tragedy, playing the sometimeimprisoned libertine antihero Count Oxtiern himself, and in 1789, the Drury Lane composer-librettist duo Stephen Storace and James Cobb adapted their operetta The Haunted Tower from Sade's 1788 play La tour enchantée, which shares its premise with one of the Crimes tales, 'La Tour de Rodrigue'. With its Sadeian inspiration unmentioned, The Haunted Tower became 'the most successful full-length opera that Drury Lane staged in the entire [eighteenth] century' and was transcribed in London as late at $1810 .{ }^{42}$ This anthology constituted the least 'disgusting' generic follow-up to Louvet that Mary Shelley could have read.

Among its tales, the final one, 'Eugénie de Franval', caters exceptionally well to the Shelleys' shared thematic concerns. 'Believed to be the best' of the Crimes, in part because it 'demonstrates [Sade]'s utmost audacity without greatly antagonizing the conventional norms of morality', 'Eugénie de Franval' presents incest as its major theme. In it, Sade 'upgrade[s]' incest 'from a leitmotif', as in other Crimes de l'amour components and the Justine cycle, 'to the very raison d'être of a story' (Seminet, pp. 163-7). From 1815 to 1819 , the Shelleys both wrote about incest, which Percy Shelley found a 'poetical circumstance'. He idealized fraternal incest in works including Laon and Cythna, or the Revolution of the Golden City (completed 1816) and 'Love's

${ }^{40}$ Philippe Seminet, Sade in his Own Name: An Analysis of Les Crimes de l'amour (Bern: Lang, 2003), p. 5.

${ }^{41}$ Katherine M. Astbury, 'The Respectable M. De Sade, literary critic', A Different Sade: Food for Thought Thursday, 7 June 2007: A British Academy discussion evening, edited by Marian Hobson (London: British Academy, 2007), britac.ac.uk/events/2007/sade/papers. cfm, pars. 2-3. Accessed 14 October 2014.

${ }^{42}$ Frederick Burwick, Romantic Drama: Acting and Reacting (Cambridge: Cambridge University Press, 2009), pp. 178, 186. 
Philosophy' (1820). He encouraged Mary Shelley to dramatize the legend of the sixteenth-century Roman aristocrat Beatrice Cenci, who was allegedly raped by her father and later murdered him. Mary Shelley transcribed and translated documentary evidence of Beatrice's story, then left it to her husband, who adapted it as The Cenci: A Domestic Tragedy (1819). And in Mathilda (1819), she wrote her own tragedy of father-daughter incest. She would not then have shied away from Sade's representation of this aberration. She might also have appreciated his feminism, which predates even her mother's. 'The femme [wife, but also, literally, "woman"] who belongs to us', Franval preaches, 'is a sort of individual whom custom has given us in bondage'. In Franval's estimation, wives must be 'utterly faithful and obedient' only because 'a man does not enjoy seeing another usurp his rights' (CJ, p. 378). Franval's mistreatment of his wife and his 'woman' (his daughter) constitute physical, intellectual, and psychological bondage. As such, the tale employs the trope of incest to expose the tyrannical patriarchal marriage and fatherhood, just as does Percy Bysshe Shelley's The Cenci and Mary Shelley's Mathilda. ${ }^{43}$

These works incorporate numerous echoes of 'Eugénie de Franval', the most conspicuous of which is the name of Victor Frankenstein's friend Henry Clerval. Harold Bloom (2009) explains Clerval's name as a reference to Mary Shelley's aforementioned stepsister Clairmont. Claiming that Frankenstein's attraction to Clerval is 'homosexual', Bloom asserts that 'further evidence' of Clerval's 'femininity' includes 'the likelihood that his name derives from that of Claire Clairmont'. In Bloom's estimation, 'Mary [Shelley] has simply exchanged the French words 'val' and 'mont'. The more feminine valley replaces the masculine mountain'. ${ }^{44}$ Perhaps, but Clerval more obviously recalls Eugénie's grandmother's confessor priest Monsieur Clervil. To begin with, Clervil and Clerval are homonyms. This is no coincidence. Manuscript evidence demonstrates that Mary Shelley chose the name Clerval after trying out and rejecting a different name. In the earliest surviving draft of Frankenstein, she at first supplies the name 'Carignan' for Frankenstein's doomed confidant. This moniker seems appropriate for the character, because it invokes the spectre of Marie-Louise-Thérèse de Carignan, Princesse de Lamballe, the gruesomely murdered confidante of Marie Antoinette. Mary Shelley inscribed the name 'Henry Carignan' twice in the early pages of the Frankenstein draft, then crossed out 'Carignan' and replaced it with 'Clerval', indicating a deliberate revision. ${ }^{45}$ The rest of that manuscript and all other

\footnotetext{
${ }^{43}$ For this reading of Mathilda, see Anne K. Mellor, Mary Shelley: Her Life, Her Fiction Her Monsters (London: Methuen, 1988), p. 200.

${ }^{44}$ Harold Bloom, Bloom's Major Literary Characters: Frankenstein (New York: Chelsea House, 2009), p. 38.

${ }^{45}$ Mary Shelley and Percy Bysshe Shelley, Frankenstein Draft A, Bodleian MS Abinger c.56, fol. 4r, ibid, fol. 4v. Shelley-Godwin Archive, shelleygodwinarchive.org. Accessed
} 
surviving ones maintain 'Clerval' as the character's name, indicating that it was changed deliberately - and by Mary Shelley, not her husband. The Frankenstein manuscripts contain thirty-three instances of 'Clerval' (and one of the misspelling 'Clairval'). Of these, two 'Clervals' in the final ('C2') notebook are in Percy Shelley's handwriting. ${ }^{46}$ Mary Shelley wrote all the others, including the initial two 'Henry Carignan Clerval' references. ${ }^{47}$ She preferred Frankenstein's friend's name to suggest the Sadeian character, even at the loss of the ominous foreshadowing that 'Carignan' creates.

For the knowing reader, Clerval's name foreshadows his development as a double of Sade's Clervil. The two characters have much in common besides their names. Both serve as models of sensibility and, more specifically, ineffectual 'good counselors' to the deeply flawed, overreaching hero. 'One of the most virtuous men of all France', Sade's Clervil is 'honest, benevolent' and 'a paragon of candour and wisdom'. He lacks the usual 'vices of men of the cloth', and exhibits only 'gentle and useful qualities'. He helps the poor, befriends the rich, 'console[s] the wretched and downtrodden' (CJ, p. 390). So does Shelley's Clerval: '[p]erfectly humane' and 'thoughtful in his generosity', he 'occupie[s] himself [...] with the moral relations of things'. For example, he tells Victor Frankenstein a cautionary tale about the ghosts of a 'priest and his mistress' who were fatally 'overwhelmed by an avalanche'. Moreover, his 'dream was to become one among those whose names are recorded in story as the gallant and adventurous benefactors of our species' (NSW 1, p. 24). This is how Sade records Clervil's name in 'Eugénie de Franval'.

While Clerval shares Clervil's virtues, he also displays the same major flaw: underestimation of man's capacity for evil. At first, Clervil decides that it is unlikely that Franval has seduced Eugénie, even after Madame Franval tells him this is true. He responds that in any case, incest is a crime best not discussed. Although Franval's incest 'existed all too concretely', Clervil finds Madame Franval's suspicion of it 'outrageously insulting', and 'indignantly refuse[s] even to consider the possibility'. This is not merely because he finds it 'highly unlikely', but because the good cleric can 'only with extreme repugnance [...] make up [his] mind to ascribe such wrongs to someone' because 'our suspicions are often the handiwork of our pride and vanity'. Clervil esteems it 'better to leave a secret sin forever hidden than to dream up imaginary ones' (CJ, p. 390). This policy enables Franval's tyranny over Eugénie. Unchecked by his counselor, Franval kills a rival for her sexual favors and convinces her to murder her mother, which causes her to die of guilt and grief and her father

11 November 2014. All Frankenstein manuscript evidence is cited from this edition, accessed on this date.

${ }^{46}$ Frankenstein Draft C2, Bodleian MS Abinger c.58, fol. 26r; ibid., 26v.

${ }^{47}$ Frankenstein Draft B, Bodleian MS Abinger c.57, fol. 39v. 
to commit suicide. Clervil lives to bear complicity in these deaths. Similarly, Clerval's refusal to investigate Frankenstein's evasion and self-alienation results in the deaths of Justine and William.

Unlike Clervil, Clerval dies prematurely, as a result of the antihero Frankenstein's outrage against Nature. But that fate makes Frankenstein paradoxically more faithful to Sade's suppressed livres philosophes than to Crimes de l'amour. Clerval's death demonstrates, to quote Justine's title, 'les malheurs de la vertue'. And for the virtuous, altruistic Clervil, outliving the unrepentant Franval is its own kind of hell. The well-intentioned young priest's awareness of his own sin of omission's role in the heroine's destruction perhaps subjects him to a sort of moral death of which Clerval's physical death at the Creature's hands is only a pale shadow. Overall, Clerval's shadowing of Clervil makes Mary Shelley's appropriation of the Sadeian name appear likely deliberate. This deliberate, detailed use of Sade's imagery strongly suggests that Mary Shelley read 'Eugénie de Franval'.

No Sadeian namesakes populate Mathilda, but this long-unpublished 1819 novella's plot has many parallels with 'Eugénie de Franval'. To begin with, both texts are concerned with father-daughter incest as their major theme. A richly allusive 'serious contribution to Romantic literature', Mathilda engages intertextually with canonical incest myths, particularly the legend of Myrrha and Cinyras as dramatized by Vittorio Alfieri. ${ }^{48}$ However, Mathilda resembles 'Eugénie de Franval' more closely than Myrrha or any of Shelley's other currently acknowledged sources. In Sade's tale, the incestuous pair are neither culturally abstract prehistoric royalty nor classical gods, but culturally situated modern human beings. Whereas Alfieri's Myrrha desires her father at first unrequitedly, both Franval and Mathilda's father desire their daughters and convince them of their complicity in this exploitation, as critics have pointed out. ${ }^{49}$ In another parallel with Sade's tale, while the aristocratic Franval is extravagantly but unwisely educated by his aristocratic father, Mathilda's father is also a 'man of rank [...] educated [...] with all the indulgence' his mother

\footnotetext{
${ }^{48}$ Audra Dibert Himes, "Knew shame, and knew desire”: Ambivalence as Structure in Mary Shelley's Mathilda', in Iconoclastic Departures: Mary Shelley After Frankenstein, ed. Syndy M. Conger, Frederick S. Frank, and Gregory O’Dea (Cranbury, NJ: Associated University Presses 1997), pp. 115-29, (pp. 116-17).

${ }^{49}$ Diana Edelman-Young, "Kingdom of Shadows": Intimations of Desire in Mary Shelley's Mathilda' Keats-Shelley Journal 51 (2002), 116-44, demonstrates that Mathilda desires her father 'despite the victimization inherent in incestuous relationships' (p. 135). For Mathilda's father as desirer and/or pursuer of his daughter, see Margaret Davenport Garrett, 'Writing and Re-Writing Incest in Mary Shelley's Mathilda' Keats-Shelley Journal 45 (1996), pp. 44-60; Robert Ready, 'Dominion of Demeter: Mary Shelley's Mathilda', Keats-Shelley Journal 52 (2003), pp. 94-110, (p. 95), finds Mathilda 'taken to hell by her father' and paralleled with the incestuous rape victim Persephone.
} 
considered 'due to a nobleman of wealth'..$^{50}$ This young man, 'nurtured in prosperity', receives 'all its advantages'. Accustomed to 'everyone' trying to 'gratify' him, he recalls the entitled Franval. Also like Franval, Mathilda's future father becomes a textbook libertine. Capable of 'careless extravagance', he indulges all 'passing whims [...] which from their apparent energy he dignified with the name of passions' while 'his own desires were gratified to their fullest extent' (p. 6). So does Franval: his philosophy of libertinism informs his seduction of Eugenie and his treatment of that seduction as a revolt against human, natural, and divine law.

Nor do the similarities between Sade's tale and Mary Shelley's end in the antiheroes' youths. While Alfieri called his Cinyras 'a perfect father, and a most perfect king', Sade and Mary Shelley accuse their heroines' fathers of fatally narcissistic parenting. ${ }^{51}$ In Sade's tale, the young nobleman M. de Colunce pursues Eugénie, but her father drives him away. In Mathilda, father and daughter similarly entertain 'among our most assiduous visitors [...] a young man of rank, well informed, and agreeable in his person'. Soon, 'his attentions towards me became marked and his visits more frequent'. Mathilda's father becomes:

restless and uneasy whenever this person visited us, and when we talked together watched us with the greatest apparent anxiety although he himself maintained a profound silence [until] these obnoxious visits suddenly ceased altogether. (p. 19)

Mathilda's father deters him, just as Franval does Colunce. By contrast, in Alfieri's Myrrha, the father promotes the suitor, but his daughter will not have him.

Myrrha is uneducated, but Eugénie and Mathilda, children of the Enlightenment, receive similar educations, which alienate them from everyone except their fathers and thereby groom them for incestuous seduction. This is one of Sade's story's major themes. '[T]he best education, wealth, talent, and the gifts of Nature are likely to lead one astray unless they are buttressed and brought to the fore by self-restraint, good conduct, wisdom, and modesty', Sade claims at the beginning of 'Eugénie de Franval' (p. 375, emphasis mine). Proving this point, Franval gives his child 'a very lovely apartment adjacent to that of her father', where she is educated by 'a highly intelligent governess, an assistant governess, a chambermaid, and two girl companions her own

\footnotetext{
${ }^{50}$ Mary Shelley, 'Mathilda', in NSW 2: p. 6. All quotes from Mathilda are cited from this volume.

${ }^{51}$ Vittorio Alfieri, quoted in The Tragedies of Vittorio Alfieri, ed. Edgar Alfred Bowring, 2 vols. (London: Bell, 1876), 2: p. 314.
} 
age, solely intended for Eugénie's amusement'. She studies with 'teachers of writing, drawing, poetry, natural history, elocution, geography, astronomy, Greek, English, German, Italian, fencing, dancing, riding and music'. In one day, she studies with 'no less than five tutors', plus her father, who schools her in 'the little tricks and games that society indulges in'. In these lessons, he teaches her to disrespect societal norms. He also physically isolates her. She attends the theatre, but only in a 'grilled box'. She spends time 'alone in her father's apartment', while he 'inculcate[s] her in what he termed his conferences' on 'his maxims on morality and religion' (pp. 381-2). Gallop reads all this rather naïvely, arguing that 'incest in Sade is not the loosing of a polymorphous perversity that is heedless to society's categories, but the unveiling of a violent passion that is inextricably linked to feelings of familiar tenderness' (Gallop, p. 33). Perhaps this is the case in some of Sade's works, but it is not in 'Eugénie de Franval'. In that story, the father-daughter relationship is one of absolute, if initially idyllic, tyranny.

So is Mathilda's education. She remembers her father's presence 'during all my studies' - during which, like her Sadeian prototype, she learns libertinage. '[W]e lived more in one week than many do in the course of several months', she confesses, 'and the variety and novelty of our pleasures gave zest to each' (p. 18). Anne K. Mellor finds this an example of 'sexual education', or pedagogy that teaches women conventionally gendered domestic roles (p. 184). Julie A. Carlson reads this curriculum as incestuous grooming dressed up as education, which Mathilda is able to understand through the 'traumatized text[ual]' representation of incest in literature she has read. ${ }^{52}$ In Kerry McKeever's reading, Mathilda's father pursues her unilaterally, and the novel 'condemn[s] fathers who fail to act like fathers'.53 Mathilda's education places her father in that category.

Sade's premise does seem to differ from Mathilda's in a significant respect: while Sade states that Franval seduces his daughter, Mathilda insists that her incestuous relationship is never physical. However, the language in which Mathilda accuses her father implies rape. He undergoes 'a change that to remember made' her 'shudder and then filled [her] with the deepest grief'. That process - terror, followed by grief - sounds like the rape survivor's cognitive process. So does the book's next line: 'There were no degrees which could break my fall from happiness to misery; it was as the stroke of lightning - sudden and entire' (p. 19). The term 'fall' connotes sexual transgression and conjures the image of the fallen woman, often a rape survivor.

52 'Julie A. Carlson, 'Attached to Reading: Mary Shelley's Psychical Reality', in Romantic Psyche and Psychoanalysis, ed. Joel Faflak, Romantic Circles, 2008, par. 11.

${ }^{53}$ Kerry McKeever, 'Naming the Daughter's Suffering: Melanchola in Mary Shelley's Mathilda', Essays in Literature 23:2 (1996), pp. 190-205, (p. 191). 


\section{Women's Literary Networks and Romanticism}

So does the image of lightning, which Mathilda associates with her father. Sade's Justine dies from a lightning strike that penetrates her genitalia, replicating the many rapes she has already endured. Mathilda claims that her father's eyes throw 'lightning' at her and blames her for his incestuous desire ('you are the sole, organising cause of all I suffer'), inducing her to tell him to speak his hidden 'dreadful word' (his desire for her) 'though it be as a flash of lightning to destroy me' (27). After his suicide, a rainstorm suddenly stops, and 'there [i]s no more thunder and lightning', which makes the lightning storm, with its threat to 'destroy' her, personify him (pp. 38-9).

Another hint that Mathilda's father rapes her is her professed refusal to tell her complete story. She signals to her interlocutor Woodville that her narration leaves out something unmentionable. 'There are many incidents that I might relate which shewed the diseased yet incomprehensible state of his [her father's] mind', Mathilda informs Woodville, 'but I will mention one that occurred while we were in company with several other persons' (p. 20). What happened outside the observation of 'other persons', she cannot say. Its unspeakability recalls incestuous rape's euphemistic depiction in Percy Bysshe Shelley's The Cenci. 'Of all words, I That minister to mortal intercourse', the incestuous rape survivor Beatrice Cenci chides her perhaps willfully oblivious stepmother:

Which wouldst thou hear? For there are none to tell My misery; if another knew

Aught like to it, she died as I will die

And left it, as I must, without a name. ${ }^{54}$

Mathilda employs the same cryptic imagery in her narration to her sympathetic friend Woodville. She cannot tell him that she is a rape survivor, but she can imply it. In every important respect, Mathilda constitutes an English adaptation of 'Eugénie de Franval'.

Consequently, Mathilda can be read as an Anglophone variation on that tale. Mary Shelley wrote Mathilda intending for it to be published, and sent it to her father so that he could help her to secure its publication. Instead, he suppressed it in horror at its depiction of at least emotional incest between a father and daughter, and it remained unpublished until it was discovered in the 1940 s by the critic Elizabeth Nitchie. Were it published during the Regency as Mary Shelley had intended, it would have made the essence of 'Eugénie de Franval' accessible for the first time to an above-ground English audience. ${ }^{55}$

${ }^{54}$ Percy Bysshe Shelley, The Cenci Act 3, scene 1, line 116, in Shelley's Poetry and Prose, ed. Donald Reiman, Neil Fraistat, and Sharon Powers (New York: Norton, 2002), p. 166.

${ }^{55}$ Elizabeth Nitchie, 'Mary Shelley's Mathilda: An Unpublished Story and its Biographical Significance' Studies in Philology 40:3 (1943), pp. 447-62. 
However, Mathilda is no mere pastiche of Sade. While his tale focuses on M. Franval, privileging his viewpoint and proceeding teleologically to his heartbreak and suicide, critics have observed that Mathilda relates its incest narrative from the daughter's perspective. ${ }^{56}$ Mathilda outlives her father and explains her experience in writing. In her letter to Woodville, she recounts 'the misfortunes to which I am the victim' (p. 6). She is able to reveal her traumatic experience because she survives him by a creative act which is itself a revision of 'Eugénie de Franval'. Sade's heroine actually commits suicide out of grief for her murder of her mother, to which her father had put her up, giving him literally the last word in their story, but Mathilda only pretends to take her own life. By this act of fiction-making or theatrical performance, Mathilda survives long enough to challenge her indoctrination and exploitation. This departure from 'Eugénie de Franval' contributes to Mathilda's legibility as a faithful yet innovative variation upon Sade.

We have seen that some of Sade's most illuminating and influential twentieth-century critics have been women. It is time to concede Mary Shelley's contribution to the important work of recovering, clarifying, translating, popularizing, and reinventing the genial spirit of Charenton, in part because of the revelations about our preconceived ideas about Mary Shelley that such an admission must provoke. Mostly, those preconceived ideas jar with the traditional image of the Sade literary protégé. Dacre, Lautréamont, Swinburne, the writers of the Contre-attaque coterie and de Beauvoir turned to Sade to shore up their own self-images as provocateurs and rebels. Mary Shelley has long been held to have done nearly the opposite. Her personal life and remarkable writings, it must be admitted, were radical, but she was also, by her own admission, long reluctant to admit her divergences from the morality of her time with respect to gender roles, sexuality, and selfexpression. '[I] roll myself in cotton at the bottom of my cage, \& never peep out', she once wrote in a letter, explaining her husband's nickname for her, 'the dormouse. ${ }^{57}$ She admitted that she was not the outward radical that her parents were. 'I am not for violent extremes, which only bring on an injurious reaction'. This seems the inevitable lesson of the aftermath of the French Revolution, which occurred in and just before her childhood, but Poovey argues that it was also 'a defense of her character' which combined 'stereotypical feminine reticence' with 'unconventional self-assertion' aimed to

${ }^{56}$ Katherine Hill-Miller, 'My Hideous Progeny': Mary Shelley, William Godwin, and the Father-Daughter Relationship (Newark: University of Delaware Press, 1995), p. 114, quoted in Edelman-Young, p. 132; Garrett, p. 52, contends that Mathilda 'focuses on the guiltfeelings of the daughter', and considers this 're-writing of incest' to be 'a major structural change in the story' from prototypes such as Alfieri's.

57 The Letters of Mary Wollstonecraft Shelley, ed. Betty T. Bennett (Baltimore: Johns Hopkins University Press, 1980-88), p. 202. 
neutralize her ambivalence about gender, sexual, and domestic convention..$^{58}$ According to Mellor, Mary Shelley's early social conventionalism, as it were, was also a form of political conservatism, as her preference for gradual social change over revolutionary schism made her a kind of Burkean conservative (p. 86). This is neither socially nor politically the portrait of a Sadeian protégé as established by Swinburne and his inheritors.

There is also the problem of Mary Shelley, mythical censor of obscene, revolutionary male genius. Mary Shelley's stereotypical reticence found its most problematic manifestation in her reinvention - some have said bowdlerization - of her husband's life and work. For instance, their friend Edward John Trelawney made her out as a convention-bound counterpoint to her husband, forever trying to force him to become or at least to appear more conventional..$^{59}$ 'A long succession' of commentators have 'arraigned Mary Shelley' for being 'a conventional slave', a social butterfly, and for 'hypocritical piety', observes her 1991 biographer Emily Sunstein. In reality, Mary Shelley's bowdlerization of his posthumous works was, as Michael O'Neill explains, 'tactical', 'consciously and reluctantly deployed' to 'serve [her] long-term strategy' of 'foster[ing] the taste by which his writing might be enjoyed'. ${ }^{60}$ In other words, she did not build an ineffectual Bonfire of the Vanities, but a successful time capsule. However, the idea of Mary Shelley as her husband's prim Xantippe (or Rénée Pélagie) persists today. It shapes Miranda Seymour's recent biography Mary Shelley (2000), which assumes that Mary Godwin (as she was in 1814) refused a chance to go skinny-dipping in a chilly Northern European stream because it offended her morals, and which glosses over all the novels that follow Frankenstein on the grounds that only her husband's inspiration allowed her own writing to become radical and noteworthy. ${ }^{61}$

Additional iterations of this idea of Mary Shelley include the many dramatizations of her life that posit her as a modest double of her vivacious stepsister Clara Jane 'Claire' Clairmont. These include Howard Brenton's play Bloody Poetry (1985), in which the men come up with the premise of Frankenstein while 'Mary' nags Shelley to abandon radicalism and Claire for her, their children, and conventional domesticity, Ken Russell's film Gothic (1986), which traps the fair, straight-haired 'Mary' (Natasha Richardson) and darker, Medusa-tressed 'Claire' (Myriam Cyr) in a virgin/whore binary paradigm,

${ }^{58}$ Quoted in Mary Poovey, The Proper Lady and the Woman Author (Chicago: University of Chicago Press, 1985), pp. 114-15.

59 Emily Sunstein, Mary Shelley: Romance and Reality (Baltimore: Johns Hopkins University Press, 1991), p. 397.

${ }^{60}$ Michael O’Neill, “'Trying to Make it as Good as I Can”: Mary Shelley's Editing of P. B. Shelley's Poetry and Prose', in Mary Shelley in her Times, ed. Betty T. Bennett and Stuart Curran (Baltimore: Johns Hopkins University Press, 2000), pp. 185-97 (p. 194).

${ }^{61}$ Miranda Seymour, Mary Shelley (London: John Murray, 2000). 
Veronica Bennett's young adult novel AngelMonster: The Haunting Story of Mary Shelley (2006), in which 'Mary', once a teenage reader of Jane Austen who wonders whom she will marry, is virtually demonically possessed (hence the title), raped (in St. Pancras Churchyard), and driven mad by a literally diabolical Percy Shelley, and only writes Frankenstein after his death. Most recently, there is Helen Edmundson's play Mary Shelley, premiered by the UK's Triangle Theatre. According to the Telegraph reviewer Jane Shilling, while Edmundson's naïve 'Mary' discovers 'Romanticism' via Percy Shelley, the 'minxy nymphet, Jane [Claire] writhes like a kitten in heat.'. ${ }^{2}$ Affirming this paradigm in nonfiction prose, Todd states in her group biography Death and the Maidens: Fanny Wollstonecraft and the Shelley Circle (2007), that in 1816 Mary Godwin was anxious for Byron 'not [to] judge her by her stepsister' and objectively declares that although 'Mary had a scandalous reputation', 'she was a proper lady in manner' (p. 174). A Mary Shelley who reads and independently, originally responds to Sade's writings does not fit the paradigm.

Nevertheless, we need to recognize Mary Shelley's avowal of Sade in Frankenstein and Mathilda in order to ask important questions about her journey as a writer and a nineteenth-century woman. Mathilda's positioning at a major turning-point in Mellor's narrative of Mary Shelley's increasing disillusion with her bourgeois idyll should make us question the role of Sade's critique of the patriarchal family and patriarchal pedagogy in this process. Secondly, like Dacre, de Beauvoir, and perhaps Gallop, did Mary Shelley avow Sade's influence partly to appear to the Sade-readers in her own literary coterie as a legitimate contributor to male-dominated literary culture? As Tilar Mazzeo has shown, Romantic writers often honored each other with intertextual 'avowals' of literary content that would today be considered plagiarism. If the 'well-versed reader', to use Mazzeo's term, could be expected to recognize appropriated content in a generally original work, this was considered homage. ${ }^{63}$ If we read Mary Shelley's name-dropping of Sade's characters and detail-oriented reinvention of 'Eugénie de Franval' as a Romantic avowal of Sade, her selffashioning as a member of his posthumous network of influence becomes explicable as part of her quest for literary legitimacy and communion with the male provocateurs of her circle.

The addition of Mary Shelley to the long-obscured pantheon of female imaginative writers who were Sade protégés must change our popular culture's notions concerning women's roles in relation to provocative art. Doug Wright's

\footnotetext{
${ }^{62}$ Howard Brenton, Bloody Poetry (New York: Methuen, 1985); Ken Russell, dir. Gothic (Virgin Vision, 1986); Veronica Bennett, AngelMonster: The Haunting Story of Mary Shelley (London: Candlewick, 2007); Jane Shilling, 'Mary Shelley', The Telegraph (15 June 2012). Accessed 2 August 2016.

63 Tilar J. Mazzeo, Plagiarism and Literary Property in the Romantic Period (Philadelphia: University of Pennsylvania, 2007), pp. 2-3, 173.
} 
heroine Madeleine Leclerc, reader of Sade with nothing original to contribute to his 'underground network', is a fictional character. Shelley, Dacre, Réage, and Carter were real. This distinction matters.

\section{Bibliography}

Alfieri, Vittorio. The Tragedies of Vittorio Alfieri,ed. Edgar Alfred Bowring, 2 vols. London: Bell, 1876.

Astbury, Katherine M. 'The Respectable M. De Sade, literary critic'. A Different Sade: Food for Thought Thursday, 7 June 2007: A British Academy discussion evening, ed. Marian Hobson. London: British Academy, 2007. britac.ac.uk/ events/2007/sade/papers.cfm.

Barbauld, Anna Laetitia. 'On the Origin and Progress of Novel-Writing', Selected Poetry and Prose, ed. William McCarthy and Elizabeth Kraft. Peterloo, ON: Broadview, 2002.

Bennett, Betty T., ed. The Letters of Mary Wollstonecraft Shelley. Baltimore: Johns Hopkins University Press, 1980-8.

Bennett, Veronica. AngelMonster: The Haunting Story of Mary Shelley. London: Candlewick, 2007.

Berchoux, Joseph. Le Philosophe de Charenton. Paris: Giguet and Michaud, 1803. Bieri, James. Percy Bysshe Shelley: A Biography: Youth's Unextinguished Fire, 1792-1816. Cranbury, NJ: Rosemont, 2006.

Blanchot, Maurice. 'Sade'. The Marquis de Sade: The Complete Justine, Philosophy in the Bedroom, and other writings, trans. and ed. Richard Seaver and Austryn Wainhouse. New York: Grove, 1965.

Bloom, Harold. Bloom's Major Literary Characters: Frankenstein. New York: Chelsea House, 2009.

Bonca, Teddi Chichester. Shelley's Mirrors of Love: Narcissism, Sacrifice, and Sorority. Albany: SUNY Press, 1999.

Brenton, Howard. Bloody Poetry. New York: Methuen, 1985.

Bridge, Matthew. A Monster for our Times: Reading Sade Across the Centuries. New York: Columbia University, 2011.

Burwick, Frederick. Romantic Drama: Acting and Reacting. Cambridge: Cambridge University Press, 2009.

Bynes, Romana. Aesthetic Sexuality: A Literary History of Sadomasochism. London: Bloomsbury, 2013.

Carlson, Julie A. 'Attached to Reading: Mary Shelley's Psychical Reality', Romantic Psyche and Psychoanalysis, ed. Joel Faflak. Romantic Circles, 2008.

Carter, Angela. The Sadeian Woman: An Exercise in Cultural History. London: Virago, 1979.

Coleman, Deirdre. 'Claire Clairmont and Mary Shelley: Identification and Rivalry within the "tribe of the Otaheite philosopher's" [sic]'. Women's Writing 6:3 (1999).

Craciun, Adriana. Fatal Women of Romanticism. Cambridge: Cambridge University Press, 2003. 
Crook, Nora, gen. ed. Mary Shelley: Novels and Selected Works, 8 vols. London: Pickering, 1996.

Crosland, Margaret, trans. 'Eugénie de Franval' and Other Stories. London: Spearman, 1965.

-. The de Sade Quartet: Four Stories from the Contes et Fabliaux. London: Owen, 1963.

—, trans. The Mystified Magistrate. London: Owen, 1965.

—, with Gilbert Lély, trans. Selected Letters. New York: October House, 1965.

—, trans. Selected Writings. London: Owen, 1964.

Darnton, Robert. The Forbidden Best-sellers of Pre-Revolutionary France. New York: Norton, 1996.

de Beauvoir, Simone. Must We Burn Sade?, trans. Annette Michelson. London: Peter Nevill, 1953.

Douthwaite, Julia V. The Wild Girl, Natural Man, and the Monster: Dangerous Experiments in the Age of Enlightenment. Chicago: University of Chicago Press, 2002.

Dworkin, Andrea. Pornography: Men Possessing Women. London: The Women's Press, 1981.

Edelman-Young, Diana. "Kingdom of Shadows": Intimations of Desire in Mary Shelley's Mathilda'. Keats-Shelley Journal 51 (2002).

Eisler, Benita. Byron: Child of Passion, Fool of Fame. New York: Knopf, 1999.

Gallop, Jane. Intersections: A Reading of Sade with Bataille, Blanchot, and Klossowski. Lincoln: University of Nebraska Press, 1981.

—. Thinking Through the Body. Columbia University Press, 1988.

Garrett, Margaret Davenport. 'Writing and Re-Writing Incest in Mary Shelley's Mathilda'. Keats-Shelley Journal 45 (1996).

Gilman, Richard. 'Position Paper'. The New York Times. 29 July 1979.

Gladden, Samuel Lyndon. Shelley's Textual Seductions: Plotting Utopia in the Erotic and Political Works. New York: Routledge, 2002.

Gonsalves, Joshua D. 'Byron - In-Between Sade, Lautréamont, and Foucault: Situating the Canon of "Evil" in the Nineteenth Century'. Romanticism on the Net 43 (2006).

Gorer, Geoffrey. 'Department of Amplifications', The New Yorker (10 January 1953).

-. The Marquis de Sade: A Short Account of his Life and Work. London: Liveright, 1934.

-. Geoffrey. The Revolutionary Ideas of the Marquis de Sade. London: Wishart, 1934.

Hayman, Ronald. Marquis de Sade: The Genius of Passion. London: Tauris, 2003. Hill-Miller, Katherine. 'My Hideous Progeny': Mary Shelley, William Godwin, and the Father-Daughter Relationship. Newark: University of Delaware Press, 1995.

Himes, Audra Dibert. "Knew shame, and knew desire": Ambivalence as Structure in Mary Shelley's Mathilda'. Iconoclastic Departures: Mary Shelley After Frankenstein, ed. Syndy M. Conger, Frederick S. Frank, and Gregory O'Dea. Cranbury, NJ: Associated University Presses 1997. 
Hunt, Lynn A. The Invention of Pornography: Obscenity and the Origins of Modernity, 1500-1800. Cambridge, MA: MIT Press, 1993.

Kamir, Orit. Every Breath You Take: Stalking Narratives and the Law. Ann Arbor: University of Michigan Press, 2001.

Ladenson, Elisabeth. 'Literature and Sex', The Cambridge Companion to French Literature, ed. John Lyons. Cambridge: Cambridge University Press, 2015.

McCalman, Iain. Radical Underground: Prophets, Revolutionaries, and Pornographers in London, 1795-1840. Cambridge: Cambridge University Press, 1988.

MacDonald, D. L. and Kathleen Scherf, eds. Frankenstein. Peterloo, ON: Broadview Press, 2002.

McKeever, Kerry. 'Naming the Daughter's Suffering: Melanchola in Mary Shelley's Mathilda'. Essays in Literature 23:2 (1996).

Mazzeo, Tilar J. Plagiarism and Literary Property in the Romantic Period. Philadelphia: University of Pennsylvania, 2007.

Mellor, Anne K. Mary Shelley: Her Life, Her Fiction, Her Monsters. London: Methuen, 1988.

Murat, Laure. The Man who Thought he was Napoleon: Toward a Political History of Madness. Trans. Deke Dusinberre. Chicago: University of Chicago Press, 2014.

Nitchie, Elizabeth. 'Mary Shelley's Mathilda: An Unpublished Story and its Biographical Significance'. Studies in Philology 40:3 (1943).

O'Neill, Michael. “'Trying to Make it as Good as I Can”: Mary Shelley's Editing of P. B. Shelley's Poetry and Prose', Mary Shelley in her Times, ed. Betty T. Bennett and Stuart Curran. Baltimore: Johns Hopkins University Press, 2000.

Pal-Lapinski, Piya. 'Byron avec Sade: Material and Spectral Violence in Childe Harold's Pilgrimage Canto IV', Byron's Ghosts: The Spectral, the Spiritual, and the Supernatural. Liverpool: Liverpool University Press, 2013.

Paulhan, Jean. 'The Marquis de Sade and his Accomplice'. The Marquis de Sade: The Complete Justine, Philosophy in the Bedroom, and other writings, trans. and ed. Richard Seaver and Austryn Wainhouse. New York: Grove 1965.

Poovey, Mary. The Proper Lady and the Woman Author. Chicago: University of Chicago Press, 1985.

Praz, Mario. The Romantic Agony, trans. Angus Davidson. London: Collins, 1962. Ready, Robert. 'Dominion of Demeter: Mary Shelley's Mathilda'. Keats-Shelley Journal 52 (2003).

Russell, Ken, dir. Gothic. Virgin Vision, 1986.

Sade, D. A. F. Les Crimes de l'amour, 4 vols. Paris, 1800.

-. La Philosophie dans Le Boudoir, Ouvrage posthume de l'Auteur de Justine. 'London' (N.P., 1795).

St. Clair, William. The Godwins and the Shelleys: the Biography of a Family, 1989. New York: Norton, 1991.

- The Reading Nation in the Romantic Period. Cambridge: Cambridge University Press, 2004. 
Seaver, Richard and Austryn Wainhouse. The Marquis de Sade: The Complete Justine, Philosophy in the Bedroom, and other writings, trans. and ed. Richard Seaver and Austryn Wainhouse. New York: Grove 1965.

Seminet, Philippe. Sade in his Own Name: An Analysis of Les Crimes de l'amour. Bern: Lang, 2003.

Seymour, Miranda. Mary Shelley. London: John Murray, 2000.

Shelley, Mary and Percy Bysshe Shelley. Frankenstein Draft A, Bodleian MS Abinger c.56, fol. 4r, ibid, fol. 4v. Shelley-Godwin Archive, shelleygodwinarchive.org.

Shelley, Percy Bysshe. Shelley's Poetry and Prose, ed. Donald Reiman, Neil Fraistat, and Sharon Powers. New York: Norton, 2002.

Shilling, Jane. 'Mary Shelley'. The Telegraph, 15 June 2012.

Soulié, Frédéric. Les mémoires du diable [1838]. 3 vols. Paris: Michel Lévy Frères, 1888.

-. Memoirs of the Devil, by Frederick Soulie, Translated Expressly for the Penny Novelist, Chapter 6. The Penny Novelist and Library of Romance, n.s. 3, no. 16 (1842).

Steiner, Wendy. Venus in Exile: The Rejection of Beauty in Twentieth-Century Art. Chicago: University of Chicago Press, 2002.

Sunstein, Emily. Mary Shelley: Romance and Reality. Baltimore: Johns Hopkins University Press, 1991.

Todd, Janet. Death and the Maidens: Fanny Wollstonecraft and the Shelley Circle. London: Bloomsbury, 2013.

Williams, Anne. 'Mummy, possest: Sadism and Sensibility in Shelley's Frankenstein'. Frankenstein's Dream'. Romantic Circles: Praxis Series (July 2003).

Wilson, Edmund. 'The Vogue of the Marquis de Sade' (1952). The Bit Between My Teeth: A Literary Chronicle of 1950-1965. New York: Macmillan, 1965. Wright, Doug. Quills and Other Plays. New York: Faber, 2005. 


\section{'Your Fourier's Failed'}

\section{Networks of Affect and Anti-Socialist Meaning in Aurora Leigh}

Eric Hood

The anti-socialist agenda of Elizabeth Barrett Browning's Aurora Leigh (1855) has received scant attention by scholars. The notable exceptions have been Cora Kaplan's comparative reading against Charles Kingsley's Christian Socialist novel, Alton Locke (1850), Deirdre David's look at EBB's intellectual conservatism, and Linda Lewis's study of the political aspects of EBB's spiritualism - a surprisingly small body of scholarship considering the centrality of the verse-novel's anti-socialist message. Perhaps others have suspected that such a study could produce only obvious results, but it is my contention that EBB's relationship with socialism is much more complicated than it might appear on the surface. Although EBB takes aim at several prominent socialists, including Cabet, Comte, Blanc, and Proudhon, 'the principal target for attack ... is ... Charles Fourier'. ${ }^{2}$ In fact, Aurora Leigh calls on Fourier by name on five different occasions (II: 483, III: 584, V: 784, VIII: 483, IX: 896), mentions his most prominent disciple, Victor Considerant (III: 585), and references Fourier's plan for a utopian community (the phalanstery) eight times (III: 108, IV: 756, V: 652, V: 784, V: 1003, VI: 210, VIII: 888, VIII: 961). But if the name of Charles Fourier is made to stand-in for the larger socialist project in Aurora Leigh, it begs the question: why Fourier in particular?

In this study I seek to locate some of the mediated affects that 'stick' to 'Fourier' in Aurora Leigh. ${ }^{3}$ Although affect is often considered synonymous with individual emotions, here, affect describes those pre-emergent forces, or inten-

${ }^{1}$ Elizabeth Barrett Browning, Aurora Leigh, ed. Kerry McSweeney (New York: Oxford University Press, 1993), Book III: line 585, IX: 869.

${ }^{2}$ Linda M. Lewis, Elizabeth Barrett Browning's Spiritual Progress: Face to Face with God (Columbia: University of Missouri Press, 1998), p. 118.

${ }^{3}$ According to Sara Ahmed, affects are sticky: 'Affect is what sticks, or what sustains or preserves the connection between ideas, values, and objects'; Sara Ahmed, 'Happy Objects', 
sities, that circulate through the body politic as well as the individual body. Affects are described as pre-emergent in that affects circulate beneath more structured forces, like language, ideology and emotions. Affects are understood as intensities because affects motivate those structured forces without necessarily directing them. Affective forces operate at various levels, some at the broad level of cultural possibility, what Raymond Williams discussed as a 'structure of feeling', others at the level of the nuclear family, and others, still, at the level of the embodied Subject. Borrowing from the radical interconnectivity of quantum physics, Brian Massumi explains how affects at different levels cross their horizons and interact with one another:

Each individual and collective human level has its peculiar 'quantum' mode (various forms of undecidability in logical and signifying systems are joined by emotion on the psychological level, resistance on the political level, the spectre of crisis haunting the capitalist economies, etc.). These modes feed back and feed forward into one another, echoes of each other one and all. ${ }^{4}$

Here, Massumi recognizes that the affects that underlie our personal feelings, political leanings, and world view rub against each other. In this collisions of affective forces (amplifying, negating, or redirecting other affects), the event emerges, or, in this case, the text.

Since affect is a pre-emergent relation, it must be studied indirectly through the ways it develops and organizes the more visible, higher-ordered systems. Therefore, in order to analyze the affective forces that underlie EBB's Aurora Leigh, I will focus on the system of meanings that emerges through the sign of 'Fourier'. The French philosopher, Charles Fourier (1772-1837), was a Romantic-era socialist whose plan for radial utopian communities based on the variety of human passions became influential during the 1840s. Much has been written about the historical Fourier and his ideas, but my interests, here, are directed more towards following the various meanings assigned to his name in the text of Aurora Leigh. Here, 'Fourier' becomes a point of convergence for a broad network of meaning that crosses over the horizons of the social, familial, and personal. I will show that 'Fourier' refers to [1] the menace of patriarchal domination and the loss of personal liberty; [2] the political defeat of utopian socialism, after 1848; [3] the threat of a revitalized socialist movement under the veil of free love; and [4] the unsanctioned erotic

in The Affect Theory Reader, ed. Melissa Gregg and Gregory J. Seigworth (Durham: Duke University Press, 2010), pp. 29-51 (p. 29).

${ }^{4}$ Brian Massumi, 'The Autonomy of Affect', Cultural Critique 31 (Autumn 1995), pp. 83-109 (p. 98). 
desires of the author. At each point in the text, one of these affected meanings may become dominant, but I will contend that all four are always present throughout. Each of these meanings has a different point of origin, or level, within the 'worlding refrains' of EBB's life and thought. ${ }^{5}$ The second and third meanings (although contradictory) coexisted in the Whig community in which was EBB was immersed, while the first and fourth meanings develop from EBB's familial experience and psycho-sexual life. As Massumi suggests with his metaphor barrowed from quantum theory, to grasp the affective forces at work in EBB's feelings about socialism, it is necessary to study the affective interactions across levels, to examine both the public connotations surrounding 'Fourier' and those meanings that are private to the author. Unpacking 'Fourier' reveals the presence of an affective network constructed out of hope and fear, shame and desire, a network that maps the dangers and insufficiencies of socialism as EBB lived them. Furthermore, the branching of this paradoxical network of meanings makes visible liberalism's ideological power to block potentially radical responses by channeling affective forces into normalized bourgeois identities, particularly hetero-monogamous sexual identities. By reading 'Fourier', as a conjuncture of affective forces operating across different levels, a clearer understanding emerges of the complexities that directed the production of Aurora Leigh, one that begins to explain why EBB - who recognized the horrors of capitalist exploitation - not only rejected socialism as a potential solution but why she focused her attacks on the theories of Charles Fourier.

\section{Fourier as Oppression}

Although Aurora Leigh is an anti-socialist text, it should be noted that the need for its anti-socialist message emerges out of a general cultural anxiety concerning capitalism, an affective force that pervaded the world-system in the mid-nineteenth century. The radical economic, political, and social instabilities that attended the modern world-system were not only visible - they were lived. The English credit bubble that fueled massive railroad expansion during the 1840s burst in 1847, sparking a global financial panic that wiped out fortunes and lasted through the mid-1850s. Then, in February of 1848, a workers' revolt in Paris inspired a revolutionary spirit that swept through much of Europe and Latin America. Meanwhile, the relocation of low-wage workers to cities, already underway for a century, continued to accelerate to meet the needs of an expanding industrial sector. Old money, governments, and ways of life were vanishing. The affective force that arose out of and reinforced

5 See Kathleen Stewart, 'Worlding Refrains' (afterword), in The Affect Theory Reader, pp. 339-53. 
these instabilities circulated throughout the capitalist world-system. Raymond Williams refers to communal affects like these as 'structures of feeling', noting the importance of not exploring an age's ideologies but how 'meanings and values ... are actively lived and felt'. ${ }^{6}$

Like all affective forces, this broad dissatisfaction with things-as-they-were was, itself, undirected and full of potentialities, translatable into fear and hope. As Emanuel Wallerstein explains, all three of the ideological attempts to channel this affective force recognized change as normal. ${ }^{7}$ If the radical democrats and socialists of the Left wanted to sweep away the old institutions and prejudices, the conservatives on the Right only argued that the pace of such changes should always be slower, tempered, often even reversed. Reformist liberalism took the center, seeking to 'control the pace of change so that it occurred at what they considered an optimal speed' (p. 6).

When working through the political messaging of this period, then, it is important to realize that nearly every author (whether of the Left, Right, or center) was responding to this affective force through social critique. But, while disillusionment was in the air, the remedies proposed by Carlyle, Marx, and Mill remained very different. If we conflate calls for social change with Leftist politics, the pointedness of EBB's early reform poetry, like 'The Cry of the Children' (1844), may make her appear more radical than she actually was. There is, after all, a recognition in the last stanzas of 'The Cry of the Children', of the overwhelming systemic forces involved in the practice of child labor that might have caused EBB to feel that calls for reform and volunteerism were impotent in the face of market pressures. In other words (and in another world), 'The Cry of the Children' might have been EBB's first steps towards a more Leftist politics, a path along which she would have found support in her avid reading of Percy Shelley, a journey that might have culminated with a different, less cynical, Aurora Leigh. By marking EBB's challenge to the status quo as a response to an underlying affective force that could be channeled into positions across the political spectrum, the confusion over EBB's politics can be made productive, pointing to 'the virtual co-presence of potentials's in her responses to the exploitation of labor. The study of affects no longer takes her political feelings as fully consistent but redirects the question, asking: what are some of the affective collisions that channeled EBB away from other positions and toward the tendencies of reform-minded liberalism?

${ }^{6}$ Raymond Williams, Marxism and Literature (Oxford: Oxford University Press, 1977), p. 132.

7 Emanuel Wallerstein, The Modern World-System IV: Centrist Liberalism Triumphant, 1789-1914 (Berkeley: California University Press, 2011), p. 1.

${ }^{8}$ Brian Massumi and Mary Zournazi, 'Navigating Movements' (interview), Hope: New Philosophies for Change, ed. Mary Zournazi (New York: Routledge 2003), pp. 210-42 (p. 213). 
Kaplan explains that there, indeed, was a gap between what EBB thought of herself as a supporter of the people and how she reacted to the political turmoil she witnessed:

She saw herself as a 'democrat', but her response to the failure of the 1848 revolutions suggests that this veneer of democracy was easily scratched. The years between ' 48 and ' 56 had left her deeply cynical about the ability of the working classes to transform themselves into good bourgeois republicans .... The picture of natural depravity set against natural virtue in Aurora Leigh confirms this disillusionment.

Her comfortably bourgeois childhood, her disparate reading, and her limited experience of the outside world, all contributed to overturning EBB's expressions of democracy. However, the complexity of the affective forces at work on her political feelings goes even deeper.

We can begin by noting that EBB's attitudes about socialism appear captured by the tendencies of liberal ideology. The attacks are predictable: socialism is both an impossibility and an affront to individual liberty. Amid the chaos of the spring of 1848 , she wrote to her sister, Henrietta, lamenting that France was now 'inextricably bound up with Communists': ${ }^{10}$

[T] hat wonderful Paris of mine where men see half-truths - so high and pure that they are not seen at all by men in general - but still half-truths, and as such dangerous or impossible to render into practice. Whatever, for instance, touches upon property is a wrong, and whatever tends to the production of social equality is absurd and iniquitous, and oppressive in its ultimate ends. Every man should have the right of climbing - but to say that every man should equally climb, because the right is equal, is a wrong against the strong and industrious (p. 81).

Then, another letter, later that spring:

In France there is every noble aspiration, there are men of splendid talents and virtues - but the ideas go up like rockets, and, in the midst of our acclamation and admiration, drop down in ashes. Little is consequent and consistent, and still less practically possible. Legislation, for the sake of one class, (and that class the most unintelligent and uncultivated)

9 Cora Kaplan, 'Introduction', in Critical Essays on Elizabeth Barrett Browning, ed. Sandra Donaldson (New York: G. K. Hall, 1999), p. 98.

${ }^{10}$ Elizabeth Barrett Browning, Elizabeth Barrett Browning: Letters to Her Sister, 1846-1859, ed. Leonard Huxley (London: J. Murray, 1929), p. 87. 
must be bad; and government controlled by mobs and sticks must be unwise. If they went on in their present way of governing, there would be an end of - not only trade and peace, but art and literature .... My idea of a republic is for every born man in it to have room for his faculties - which is perfectly different from swamping individuality in a mob (p. 83).

From 1850 she writes, 'If Fourierism could be realized (which it surely cannot) out of a dream, the destinies of our race would shrivel up under the unnatural heat, and human nature would, in my mind, be desecrated and dishonored .... Genius is always individual. ${ }^{11}$ Across these letters we read of the impracticality of economic alternatives and the sanctity of bourgeois individuality. EBB had been repeating these tropes for years, which she recycled again in Aurora Leigh as 'Fourier's void' (IX: 868) and the 'poet's individualism' (II: 478, VIII: 429).

Although her commitments were centrist, recent scholarship has attempted to cast EBB's politics in a radical light, focusing on the aspects of her work that appear proto-feminist. Lana Dalley, for example, finds in Aurora Leigh 'a new feminist economic discourse' ('Least', p. 527) that reconciled the labor of the domestic sphere with the economic discourse surrounding the marketplace (pp. 528-9), emphasizing the poem's 'revolutionary potential' (p. 539). While not without merit, these analyses are more attuned to the nascent origins of contemporary gender politics than the liberal class politics that informed much of EBB's thinking. Even more, they gloss over the comfort with which EBB existed inside the affective network of liberal reformers. Simon Avery points out that the Barretts were not disinterested but 'fervent supporter[s] of the Whigs, the party of opposition whose political philosophy had at its heart a fundamental concern with the legal, civil, and religious rights of the individual'. ${ }^{2}$ The affective community of Whigs that EBB entered through her father's library and by the family's political activity (including campaigning locally for the Reform Bill) directed her protests, encouraging her to relate to the personal dimensions of politics and interrupting her analyses short of grappling with the systemic forces at work. In short, she was ideologically joined to the network of reformers, aligned with the manufacturing interests of the middle-class. Accordingly, she was fearful of revolution, which she often equated with mob violence (pp. 409-10).

Despite her wealth of reading, her liberal-minded focus on personal liberty meant her politics remained arrested at the level of judgments concerning

${ }^{11}$ qtd. in Lana L. Dalley, 'The Least "Angelical" Poem in the Language: Political Economy, Gender, and the Heritage of Aurora Leigh,' Victorian Poetry 44: 4 (2006), p. 529.

${ }^{12}$ Simon Avery, 'Telling It Slant: Promethean, Whig, and Dissenting Politics in Elizabeth Barrett's Poetry of the 1830s'. Victorian Poetry 44: 4 (2006), pp. 405-24 (p. 405). 
individual morality. In the words of her biographer, Margaret Forster, her opinions were 'fine sounding political generalizations' that 'did not always properly connect cause and effect. She tended to see effects and assume both cause and cure' (p. 219). In fact, her bookishness may have been an obstacle to viewing the larger social structure. Deirdre David suggests that her dependence on reading about social issues as a substitute for worldly experience drove her toward conservatism, ${ }^{13}$ and Dalley demonstrates that she echoed the liberal J. S. Mill (Dalley, p. 529, 536) just as Kaplan points to the overbearing influence of the more conservative Thomas Carlyle (p. 100). There can be no denying something of Mill in EBB's logic and Carlyle in her tone, but there is also an emotional excess to EBB's anti-socialist feelings, an obsessive circulation and violence, that these analyses do not answer.

Consider, in another letter from 1850 written to her mentor, Mary Russell Mitford:

I love liberty so much that I hate Socialism. I hold it to be the most desecrating and dishonoring to Humanity, of all creeds. I would rather ... live under the absolutism of Nicolas of Russia, than in a FourierMachine, with my individuality sucked out of me by a social air pump. ${ }^{14}$

There is, of course, the repetition of 'desecrate and dishonor', of 'the human' and 'individuality', throughout all the letters, but there is an added brutality in this response ('sucked out of me by a[n] ... air pump') that also indicates an affective intensity existing beyond the standard Whiggish objections channeling her fear.

The question, thus, shifts from where do EBB's political tropes originate to where do these attacks against Fourier and socialism draw this additional affective intensity? Some answers might be found in a pair of letters. In the first, written to a frustrated Robert Browning before they married, she makes a connection between the absolutism of the State and her father's controlling behavior, which she judged to be symptomatic of the greater tyranny of State power. 'The evil is in the system', she writes, 'and he [her father] simply takes it as his duty to rule ... like the kings of Christendom, by divine right'. ${ }^{15}$

${ }_{13}$ Deirdre David, Intellectual Women and Victorian Patriarchy (London: Cornell University Press, 1987), pp. 97-148.

${ }^{14}$ Elizabeth Barrett Browning, The Letters of Elizabeth Barrett Browning to Mary Russell Mitford, 1836-1854, ed. Mary Russell Mitford, Meredith B. Raymond, and Mary Rose Sullivan, 3 vols. (Waco, Texas: Armstrong Browning Library of Baylor University, 1983), III: p. 302 .

${ }^{15}$ qtd. in Simon Avery, 'The Voice of the Decade: Elizabeth Barrett's Political Writings of the 1840s', in Elizabeth Barrett Browning, ed. Simon Avery and Rebecca Stott (New York: Longman, 2003), p. 107. 
The second letter, written after her elopement, and amidst the turmoil of 1848, draws 'communism' into this established cluster of 'father', 'tyranny', and 'absolutism'. EBB writes:

As to communism, surely the practical part of that, the only not dangerous part, is attainable simply by consent of individuals ... But make a government-scheme of even so much, and you seem to trench on the individual liberty. All such patriarchal planning in a government issues naturally into absolutism. (Mitford, III: p. 235)

This linking of communism to 'patriarchal planning' and 'absolutism' is telling. During the year and half between these two letters, EBB had eloped with Robert Browning and fled the country to escape the house of her domineering father who refused to allow any of his daughters to marry. By all accounts this act of rebellion against her father was terribly difficult for her. Since her mother's death, she had become remarkably close to her father, locked in what looks like codependency: EBB appeared to be suffering from depression and anorexia nervosa, her father from insatiable grief. ${ }^{16}$ The first letter to Robert Browning provides some indication that she was already preparing for the separation from her father by constructing a narrative that at once justified her leaving and mitigated her father's responsibility for her distress by redefining the domestic situation in political terms. But the second letter reveals the emotional toll of the actual break. Indeed, when friends saw EBB in France they were startled by the poor condition of her health. Physically and emotionally broken, a friend wrote of EBB: she is 'nervous, frightened, ashamed, agitated, happy, miserable', and, 'in a most feeble state' (qtd., p. 107). Her father had disinherited her, and then, two miscarriages followed. It seems fair to assume that, on one hand, she was angry with her father for his cruelty, and, on the other, she was angry with herself for her own. ${ }^{17}$

Meanwhile, already committed to linking her familial hardships to political struggle, the rebellion in Paris likely hit too close to home. Her switch in the letters from the patriarchal power of 'kings' to that of 'communists' found support in the Whig politics she had already adopted, but what creeps into her letters by 1850 is a violent emotional energy that would lead to the attacks on socialism in Aurora Leigh. Thus, 'Fourier' appears to have been captured by affective forces in EBB's life that were contradictory yet overlapping. An affective force at the geo-cultural level of protest against things-as-they-were

${ }^{16}$ Peter Dally, Elizabeth Barrett Browning: A Psychological Portrait (London: Macmillan London, 1989), pp. 27-30.

${ }^{17}$ See also David, pp. 133-4. 
was directed towards a concern for individual expression and morality thought to be incommensurate with socialism by affective tendencies circulating within Whig networks. Furthermore, affective forces that operated at the level of EBB's family added an emotional intensity to EBB's suspicion of revolution. Fourier's association to socialism, which was linked in the Whig imagination with state paternalism, became a reminder of her overbearing father's oppressive governance, while the 1848 insurrection seemed to be a restaging of her guilt-ridden challenge to the law-of-the-father.

\section{Fourier as Failure}

Thus, an uncanny conjuncture in EBB's personal history and the history of capitalism reveals, in part, the affective forces mediating the critique of socialism in Aurora Leigh and directing it towards experiencing socialism, even as an idea, as oppressive. But additional affective forces push 'Fourier's' network of meanings to branch in other directions, as well. One of these was the broad sense of the Left's inefficacy. This affecting and affected narrative emerged out the fall of the French Jacobin government in 1794, and by mid-century, following the disastrous uprisings of 1848 , this 'worlding refrain' gained a new currency. Indeed, during the 1850s liberal thinkers felt that the threat of socialist movements was generally past. In the words of an American newspaper, in 1854, 'History has pronounced Socialism, as Communism, a gigantic failure. ${ }^{18}$ Moreover, if socialism's moment was thought to have already passed by the 1850s, it might have been thought even further removed for Fourierism.

From the beginning, Fourier's writings were hardly the material from which one would expect a post-Enlightenment revolutionary movement to spring. Perhaps more in tune with Dada or Surrealist poetics, which he preceded by nearly a century, Fourier's writing might generously be called anti-rationalist. To those less sympathetic, however, Fourier was nothing short of mad. He imagined wild systems for processes as mundane as the proper distribution of melons. He classified adultery into a progressive forty-nine level 'Hierarchy of Cuckoldom. ${ }^{19}$ He predicted that the oceans would one day be transformed into 'a sort of lemonade' (p. 405). Although Friedrich Engels considered Fourier a brilliant satirist, ${ }^{20}$ and Roland Barthes read him as a designed practitioner

18 'Letters from England, No. 6: The Refugee - Louis Blanc', New York Daily Times, 4 October 1854, p. 2.

${ }^{19}$ Charles Fourier, The Utopian Vision of Charles Fourier; Selected Texts on Work, Love, and Passionate Attraction, ed. Jonathan Beecher and Richard Bienvenu (Boston: Beacon Press, 1971), pp. 183-5.

${ }^{20}$ Ian Patterson and Gareth Stedman Jones, 'Introduction', in Charles Fourier, The Theory of the Four Movements (Cambridge: Cambridge University Press, 1996), p. xi. 
of a 'baroque semantics, ${ }^{21}$ Fourier's most accomplished biographer, Jonathan Beecher, remarked that he 'would not care to argue that the man was entirely sane. ${ }^{22}$ For Fourier's contemporaries, the weirdness of his 'speculations ... inevitably became an embarrassment to his enthusiasts'. ${ }^{23}$

Fourier's ideas remained little more than a subject of curiosity during his lifetime, but, after his death, his followers transformed his theories by stripping away their 'philosophical, libidinal, and cosmological extravagances' into a movement of considerable political force (p. 6). The 1840s saw a resurgence of Fourierism in America, Russia, and France. During the 1848 uprising in Paris, Fourierists, including Victor Considerant, were a highly visible faction of the Left coalition. Meanwhile Fourierism found support among rural working poor, and plans were made to establish phalansteries across the French countryside.

When the revolution turned violent in June of 1848 , however, the pacifism of the Fourierists made them irrelevant to the realities on the ground. ${ }^{24}$ Neo-Jacobin elements advanced the revolution by staging violent clashes in the street, leaving Fourierism not so-much rejected as essentially 'bypassed':

If one scene of June 1848 best captured this impotence, it was [the American] Garth Wilkinson sitting in bed one night plodding through an obtuse exposition of Fourier's law of the series while fighting raged between Parisian insurgents and the National Guard in the streets below. Fourierism remained vital only as long as class tensions and political positions could be bridged by compromise that blended socialist and capitalist forms in roughly equal parts. This proved impossible in 1848, and though few realized it, the utopian socialist moment in France had been irretrievably lost. (p. 339)

By the time Aurora Leigh was completed, the socialism of Charles Fourier felt 'irretrievably lost', not only in France, but throughout the capitalist worldsystem. Of the numerous Fourierist communities founded in America, only the North American Phalanx was still operating. Meanwhile in England, Fourierism had largely been assimilated into the Christian Socialist movement (p. 312).

It is with these recent defeats in mind that EBB's ideal reader first encounters Aurora's declaration to Romney in book two: 'your Fourier's failed' (483). Seen

${ }^{21}$ Roland Barthes, Sade, Fourier, Loyola (New York: Hill and Wang, 1976), p. 99.

22 Jonathan Beecher, Charles Fourier: The Visionary and His World (Berkeley: University of California Press, 1986), p. 12.

${ }^{23}$ Andrew Loman, 'Somewhat on the Community-System': Fourierism in the Works of Nathaniel Hawthorne (New York: Routledge, 2005), p. 12.

${ }^{24}$ Carl Guarneri, The Utopian Alternative: Fourierism in Nineteenth-Century America (Ithaca, N.Y.: Cornell University Press, 1991), pp. 336-9. 


\section{Women's Literary Networks and Romanticism}

from the repetition of the same phrase in book eight (434), the occurrence in book two can take on a prophetic quality, but this judgment is misleading, since even in the initial utterance Aurora is already speaking in the past tense: 'your [Fourier has] failed'. At this point in the narrative Romney has hardly even started in his utopian socialist enterprise before Aurora dismisses his work. The reason, of course, is that Aurora is making statement of fact and not a prediction. 'Fourier' in this sense is a marker of Romney's naiveté, which he will have to overcome before he can be a suitable partner for Aurora. Thus, the narrative simply plays out what Aurora has felt to be true all along: Romney is a well-intended, but meddling, fool.

In Aurora Leigh, socialism is felt to be a callow enterprise that miscalculates the potential of 'the most unintelligent and uncultivated' classes (Browning, Sister, p. 83). In an early scene that seems intended to convey the aristocratic insensitivity of Aurora's aunt, it is said of Romney:

the sun of youth

Has shone too straight upon his brain, I know,

And fevered him with dreams of doing good

To good-for-nothing people. (II: 243-6)

Aurora's interruption at this moment appears to mark a disapproval of her aunt's conservative politics, but later, when Aurora sardonically remarks, 'Now may the good God pardon all good men' (IV: 506) the political difference between these two women verges on collapse. Aurora, at least in part, shares her aunt's negative assessment of the working-class, and echoes Edmund Burke's judgment of the 'swinish multitude', proclaiming, 'it takes a high-souled man, / To move the masses, even to a cleaner sty' (II: 480-1). Romney later repeats this sentiment word for word (VIII: 431-2), to which he adds a biblical comparison of the poor he tried to assist with the demon-possessed herd of swine:

Sty or no sty, to contrive

The swine's propulsion toward the precipice, Proved easy and plain. I subtly organized And ordered, built the cards up higher and higher, Till, someone breathing all fell flat again. (VIII: 446-50)

Romney's experience compels him, by the end, to admit that his Fourierism, against 'the men and women of disordered lives' (VIII: 889), amounted to nothing more than 'unreal remedies' (VIII: 804), and Aurora gently excuses him, for 'He mistook the world' (IX: 709).

By the 1850s the voices of liberalism had kindly dismissed Louis Blanc, another Parisian socialist from 1848, in much the same way: 'History has 
pronounced Socialism, as Communism, a gigantic failure - still it will hereafter pronounce it a generous failure' ('Letters', p. 2., emphasis added). In Aurora Leigh, Romney is similarly 'a generous failure', sharing with Louis Blanc the tragic combination of being 'heroic, even if mistaken' (p. 2). What is important for readers is to recognize that Aurora Leigh never asks them to take the threat of socialism seriously. By labeling Romney's program as Fourierist, EBB writes socialism off as nothing more than impotent fancy.

\section{Fourier as Free Love}

Although EBB's struggle against her father's enactments of patriarchal oppression and the historical tragedies of 1848 provide some explanation for the attitudes surrounding socialism in Aurora Leigh, both leave one question still unanswered: why 'Fourier'? I mean, why Fourier in particular? When we consider that on many economic and social issues Fourier's philosophy was more tolerable to the Liberal, or Whig, position than the other prominent Socialists, he seems like a curious choice. Fourier did not stand opposed to private property or wealth, and his system was centrally concerned with the free development of the individual. Even the liberal-minded J. S. Mill admired much in Fourier's teaching. ${ }^{25}$ As Michael Levin notes, '[o]ne might suggest that Fourier was Mill's favorite socialist because he was the least socialist among them' (p. 80, n. 13).

So then why Fourier instead of other discredited socialists, like Louis Blanc or Proudhon - who get only scant attention in the text? We know, for example, that in a letter written to Mitford dated 15 March 1853, EBB confides that she has been busy reading Proudhon while working on a 'new poem', which was Aurora Leigh (III: p. 381). If EBB had been searching for a socialist foil for her verse-novel, why did she feel that 'Fourier' carried an affective force that 'Proudhon' did not? After all, Proudhon was not only associated with the failure of 1848 but he was still actively agitating while the verse-novel was written.

The answer, it appears, is that Proudhon did not have the phalanstery. Any of the radicals of 1848 could have stood in for the common claim that socialism was an historic failure, but Charles Fourier, and his doctrines, were uniquely positioned to act as symbols of socialism's sexual immorality, a charge that widely circulated by the mid-1850s. Thus, 'Fourier' became part of a peculiar cultural contradiction, an affectively charged sign with a network of meanings that referred, at once, to the pitiful socialist movements vanquished in 1848 and to the new threat rising against bourgeois order. In the same year Aurora Leigh was published, an article appeared in the liberal, reform-minded New

${ }^{25}$ Michael Levin, 'John Stuart Mill: A Liberal Looks at Utopian Socialism in the Years of the Revolution 1848-49', Utopian Studies. 14: 2 (2003), pp. 72-80. 
York Daily Times, warning the public against complacency following the defeat of the socialist movements after 1848:

The impression has been created that the danger is past - that the advocacy of Socialism, and especially of those aspects of it which involve the overthrow of the Marriage institution, have been abandoned - and that there can be no occasion for any further anxiety concerning its progress. This, in our judgment, is a very great mistake. ${ }^{26}$

The liberal paradox concerning socialism after 1848 was that although socialism was proven to be a political failure, it still harbored the potential for 'the overthrow of the marriage institution', a construction that at once preserved the ideological claim of socialism's inefficacy as an economic alternative while it kept alive the specter of a subversive cultural revolution from the Left. Indeed, the article's main thrust is to show that, ' $[\mathrm{t}] \mathrm{he}$ championship of Socialism, or universal Libertinism and Adultery, ... is but another name for the same thing' (p. 2). According to this narrative, after socialism was defeated and discredited, it was driven underground, where it hatched a conspiracy to swell its ranks using the seductions of 'Free Love':

Their assaults upon the system compelled a change of tactics; Socialism ceased to be openly advocated by its devotees, through their accustomed channels. Argument was ostensibly abandoned .... [C]overt modes of advocacy have been substituted for open argument, and has served a double purpose - diverting public attention to the object sought, and enlisting public sympathy for the evils attributed to the Christian system of society, and thus preparing the way for the remedies they have in view. (p. 2)

Joined in this socialist plot are the advocacy of 'Free Love', 'Spiritualism', and the 'Women's Rights movements' (p. 2). The radical Left had been accused of advocating free love as early as the 1790 s, but, in the wake of 1848 , it is the teachings of Charles Fourier that come to be seen as the foundation of this resurgent socialist threat.

'Fourier', the report charges, 'teaches the "higher harmonies" of loving groups', and, as scandalous as these claims of a Fourierist philosophy advocating group-sex sound, they are nonetheless correct (p. 2). Fourier's theory of human nature included the 'butterfly passion', or the love of variety, which asserted

26 'The Free Love System', New York Daily Times, 8 September 1855, p. 2. My thanks to Michael Moon for directing me to this article in his conference paper, 'Idiocies Urban and Rural', presented at the 2009 International Conference on Romanticism in New York. 
that men and women have a natural proclivity to flit from one activity to the next, or among sexual partners. The practice of marriage was, therefore, to be abolished.

A close reading reveals that the threat of Fourierist free love is a considerable obstacle in Aurora Leigh. For, while Romney's socialism is generally considered quaint, his free love practices represent an honest danger to Aurora's virtue. For example, when Aurora refuses to marry Romney, she rejects him on the grounds that she refuses to live like a mistress:

Sir, you were married long ago.

You have a wife already whom you love

Your social history. (II: 408-10)

Despite the nature of the charge, these lines read rather ambiguously. Romney's prior marriage is only metaphoric, and Aurora seems only to be suggesting that she would be a neglected spouse. But then she continues:

\section{Bless you both, I say.}

For my part, I am scarcely meek enough

To be the handmaiden to a lawful spouse.

Do I look like a Hagar, you think? (II: 410-3)

Aurora's rebuff is becoming more and more accusatory as it progresses. The repetition of this claim to a 'mistress' acquires a gravity that begins to challenge its status as only a metaphor. Even more, the comparison to Hagar (the Biblical Abraham's servant and mistress) joins together the dual foundation of Fourier's system - menial labor and polyamorous sexuality - at the site of the female body, especially in light of Romney's plan to set up a phalanstery with Aurora as his helpmate. The charge reaches its apex in the final set of wordplays:

You treat marriage too much like, at least,

A chief apostle: you would bear with you

A wife ... a sister ... shall we speak it out?

A sister of charity. (II: 408-17)

This last cluster not only summarizes the previous point but extends it. Carrying over the use of Biblical allusions, the Apostle Peter's endorsement of a celibate marriage provides an echo of the theme of the neglected spouse found in lines 408-10. But the phrase 'A wife ... a sister' goes beyond providing emphasis and generates a double entendre, suggesting something at once both polygamous (recalling the comparison to Hagar) and incestuous. Yet, despite its repetitions the passage has been building to the final, nearly unspeakable, 
charge. Romney would have Aurora as a 'sister of charity', a phrase which could refer to either a nun (a woman emptied of female sexuality) or a prostitute (female sexuality's lurid embodiment).

The peril of lascivious sexuality is further developed when Howe's party descends into what Kaplan calls 'a fully pornographic vision' of Lady Waldemar at work in Romney's phalanstery (p. 94). The immodest scene is related by a student who has been arguing against the 'prejudice of sex / And marriagelaw' (V: 705-6). Against this affront to Christian decency, Sir Blaise seems to speak for the author when he declares Romney's scheme, 'a general concubinage expressed / In a universal pruriency' (V: 726-7). For Kaplan, the raunchy episode is one 'where corrupt sensuality is vividly evoked as a byproduct of utopian socialism' (pp. 94-5).

Finally, by book eight, Romney confesses outright to what has happened inside his phalanstery. Romney is one of those 'socialistic troublers of close bonds' (VIII: 901), and admits,

I had my windows broken once or twice

By liberal peasants naturally incensed

At such a vexer of Arcadian peace,

Who would not let men call their wives their own.

(VIII: 917-20)

The working-class, who in Aurora Leigh are strikingly prone to mob violence, restore their rural patriarchy by defending traditional sexual relations, rebuffing the perversity of Romney's free love system.

David labels Romney a Christian socialist (p. 120), and Lewis rejects the idea that Romney followed Fourier's system of free love, citing that 'he proposes traditional marriage to both Aurora and Marian' (p. 120). However, there is ample reason to question to what extent any of the marriage proposals, or domestic situations, in the verse-novel qualify as 'traditional'. Furthermore, the suggestion that Fourierism might exist apart from free love, as though free love was a simple component of Fourier's socialism that one might choose to either follow or reject, is misleading. Unlike Fourier's bizarre cosmology, which his disciples often ignored or suppressed, the practice of free love was inextricably bound up with daily life in the phalanstery, both in the minds of Fourierists and in the broader social discourse. Fourierism without free love might only be intelligible as Owenism, and it is telling that Lewis understands these movements to be 'very similar' (p. 117). I have been arguing, however, that the choice of Fourier over Robert Owen as the poem's most prominent socialist foil was neither an accident nor an oversight, and that the moral threat of free love is one of the central concerns in the Aurora-Romney love plot. 


\section{Fourier as Desire}

Yet admittedly, Aurora Leigh resolves the sexual crisis posed by Romney's Fourierism in marriage, a solution that is all the more enigmatic considering the author's opinion of the institution. For, although EBB participated (for what appear to be very personal reasons) in the anti-socialist discourse of her day, she was not a defender of traditional marriages. In fact, her understanding of sexuality in many ways mirrored Fourier's. Like Fourier, she rejected the conventional idea that love was the joining of complements, of two separate yet incomplete powers of male and female. For example, Aurora chastises Romney for thinking as much when she says,

You misconceive the question like a man, Who sees a woman as the complement Of his sex merely. You forget too much That every creature, female as the male, Stands single in responsible act and thought As also in birth and death. (II: 434-9)

And also like Fourier, she found the economic and contractual nature of marriage distasteful. She wrote in a letter, 'I never could make out how some women, mothers and daughters, could talk of [marriage] as of setting up a trade'. ${ }^{27}$ The particulars of each marriage were of no concern; in her view, the entire system of marriage produced inequality. In her diary, dated 1 September 1831, she records a nightmare that she was married and frantic to have the bond dissolved (p. 151). 'I never will marry', she declares; marriage is 'a foolish thing. ${ }^{28}$ Even up until a few months before she married Robert Browning, she reasserted her wish to remain single in a letter to Mitford (pp. 150-1). Throughout her life, EBB rejected 'Marriage in the abstract' ${ }^{29}$ and was at least rationally in agreement with the Fourierist principle that marriage robbed women of their independence, a point she makes repeatedly throughout Aurora Leigh, as Dalley has already shown.

27 Robert Browning and Elizabeth Barrett Browning, The Brownings' Correspondence, ed. Philip Kelley and Ronald Hudson (Winfield, KS: Wedgestone Press, 1984), XII: 62-3; qtd. in Rebecca Stott, 'How Do I Love Thee?: Love and Marriage', in Elizabeth Barrett Browning, eds. Simon Avery and Rebecca Stott (New York: Longman, 2003), p. 150.

${ }^{28}$ Elizabeth Barrett Browning, Diary by E. B. B.; the Unpublished Diary of Elizabeth Barrett Barrett, 1831-1832, ed. Philip Kelley and Ronald Hudson (Athens: Ohio University Press, 1969), p. 111, emphasis retained.

${ }_{29}$ Browning and Browning, Correspondence, XII: p. 63; qtd. in Stott, 'How Do I Love Thee?', p. 150. 
But even laying her intellectual objections aside, EBB was also subject to intense desires that likely contributed to her aversion to marriage. Despite layers of psychological repression, EBB's writings suggest that she experienced embodied affective forces with potentialities that extended far beyond the confines of heteronormal marriage, sexual desires that might have attracted her to the amorous freedoms offered by Fourier's phalansteries. For example, in what looks to be a preparation for her elopement with Robert Browning, she developed a guilt-ridden taste for the release of erotic fiction (Dally, p. 81). Under the barest cover of humor, she expressed her unspeakable passions in missives to Mitford. In one such letter she jokes as if she were a young woman still coming to grips with her sexual maturity, 'How astonished [father] would be if I had [Richard] Horne and Robert Browning upstairs in my bedroom!' (p. 81). She was thirty-six.

Then there was George Sand. EBB so obsessed over Sand that she drove Robert to jealousy (p. 152). The attraction was complicated. On the one hand, it was literary. She vigorously defended Sand's writing against the opinions of Mitford and Richard Hengist Horne, calling Sand 'A true woman of genius' (Mitford, II: p. 85) and placing Sand in the 'triumvirate' of great French writers along with Balzac and Hugo. ${ }^{30}$ If in February of 1844, EBB was only willing to go so far as to proclaim Sand, 'the greatest female genius the world ever saw - at least since it saw Sappho' (Correspondence, VIII: p. 211), by March of the same year she had adjusted her opinion even more in Sand's favor: 'George Sand', she wrote to Mitford, 'is the greatest female poet the world ever saw. The French language grows divine as she speaks it' (II: p. 392, emphasis added). The talk of divinity, here, may be misleading, for what EBB noticed in Sand was her earthy 'aggrandizement of the physical aspect of passion' (II: p. 85). Sand was 'naughty' (II: p. 195), 'shameless', 'a fallen angel' (II: p. 85). And of Sand's 'naughty books' (II: p. 86), the one that impressed EBB most deeply was Lélia (Dally, p. 81). In a confession that playfully reveals her autoerotic impulse, EBB admits to Mitford that Lélia,

made me blush in my solitude to the ends of my fingers - blush three blushes in one ... For Her [sic] who [could] be so shameless - for her sex, whose purity she so disgraced - [and] for myself in particular, who [could] hold such a book for five minutes in one hand while a coal-fire burnt within reach of the other. (II: p. 93)

The strength of the affective force behind EBB's emotional response is indicated by the severity of her swings between desire and shame. As one hand held the

${ }^{30}$ Elizabeth Barrett Browning and Frederic G. Kenyon, The Letters of Elizabeth Barrett Browning, 2 vols. (New York: The Macmillan company, 1899), II: p. 124. 
book, the other was left perilously to decide between the flames of modesty and satisfaction. Peter Dally observes that where EBB says she felt the desire to burn certain books, 'what she was surely saying was that she felt burned by them' (p. 81). Later, she denied ever reading Lélia, 'for all its eloquence' (Mitford, II: p. 462.), citing Sand's 'disgusting tendency ... towards representing the passion of love under its physical aspect' (p. 462). Yet, she returned to Sand - whose Christian name was Aurore - for inspiration time and time again, including, as the name suggests, as a model for the character of Aurora Leigh. ${ }^{31}$

Perhaps the attraction was never anything more than that of a fan to her literary idol, but this should not cause us to dismiss the erotic layers these relations often express. Kaplan notes that EBB was both 'fascinated and repelled by the androgyny involved in Sand's masculine charade' (p. 88). She dedicated two sonnets to Sand in her 1844 Poems: one titled 'a recognition', the other 'a desire'. Her first attempt to see Sand in Paris had been frustrated, so when EBB got a second chance, she would not be denied; 'I won't die ... without seeing George Sand', she scolded Robert (Mitford, III: p. 347). Against the dangerous cold, and Robert's wishes, EBB made the trip, respirator in tow (Browning and Kenyon, II: p. 55). Her visits with Sand must have been worthy of her fantasies. To Robert's disgust, Sand received them in a room with a bed where she entertained a company of young men - 'a society of the ragged Red diluted with the lower theatrical' (Mitford, III: p. 353). 'What a strange, wild wonderful woman' (p. 340), EBB remarked; 'I do not love her, but I felt the burning soul through all that quietness' (Browning and Kenyon, II: p. 57). She twice kissed Sand on the lips on her first visit (Mitford, III: p. 349), a thrill that Forster insists 'almost made her faint'. ${ }^{32}$

Superadded to the affair was Sand's association with Fourierist circles. ${ }^{33}$ Fourierism and the 'system of free love' allowed for all these expressions of desire. Whether in same-sex or opposite-sex partnerships, whether participating in coupling or group intimacy, Fourier's law of 'passional attraction' asserted that social harmony could only be achieved through the unfettered expression of desire. Anticipating Freud's Civilization and Its Discontents (1929), Fourier posited that the evils of 'civilization' - Fourier's term for modern society were chiefly the result of repressed sexual appetites. In a manuscript that was suppressed by Fourier's disciples, but is now seen as an iconic expression of Fourier's rich psychological theory, Fourier relates the tale of Madame

${ }^{31}$ Kaplan, 'Introduction', p. 88; Patricia Thomson, George Sand and the Victorians: Her Influence and Reputation in Nineteenth-Century England (London: Macmillan, 1977), pp. 55-6.

32 Margaret Forster, Elizabeth Barrett Browning: A Biography (London: Chatto \& Windus, 1988) p. 260.

33 Sand, herself, was never a Fourierist, but she was routinely published in the Fourierist presses and kept a friendly correspondence with Victor Considerant. 
Strogonoff, a Russian princess who sadistically tortured a beautiful female slave with pins. He asks,

What was the motive for her cruel behavior? Was it jealousy? No, it was lesbianism. Madame Strogonoff was an unconscious lesbian; she was actually inclined to love the beautiful slave whom she tortured. If someone had made Madame Strogonoff aware of her true feelings and reconciled her victim, they might have become passionate lovers. But remaining unaware of her lesbian impulse, the princess was overcome by a counterpassion, a subversive tendency. She persecuted the person who should have been the object of her pleasure. (p. 353)

Strogonoff's malice was not caused by her same-sex desire, but by her prejudicial restraint against it. For Fourier the denial of any sexual desire led to the manifestation of cruel 'counterpassions', so that, 'If a man born to be a hair-plucker or a heel-scratcher in love is not able to satisfy his mania, if he is thwarted and mocked at by those to whom he reveals his penchant, he will succumb to other, harmful manias' (p. 354). However, if these libidinal impulses were not repressed but allowed to be freely and openly acted upon, they could be harnessed for the benefit of society:

My theory is limited ... to utilizing the repressed passions just as nature gives them and without changing anything. That is the whole mystery, the whole secret of the calculus of passionate attraction. We don't ask whether God was right or wrong to endow human beings with particular passions; the societary order utilizes them without changing anything and just as God has given them. ${ }^{34}$

Rejecting all but the barest notion of moral sexual restraint, Fourier's phalansteries were organized around serving the full diversity of human sexual desires. The erotic wishes of sexual minorities and 'perverts' were both respected and accounted for (Beecher, p. 309). There were more than half a dozen varieties of organized public orgies (310-1), and Fourier even encouraged older women to take on younger men as sexual partners - an idea frequently lampooned by his critics but one with which EBB was already comfortable (Loman, p. 13).

Yet, even in light of evidence suggesting the plurality of her sexual desires I would not suggest that EBB's attacks on free love Fourierism were a crude public screen. Instead, it is important to note that emotions, like disgust,

34 p. 252; qtd. in Naaman Kessous, Two French Precursors of Marxism: Rousseau and Fourier, Avebury Series in Philosophy (Brookfield, Vt.: Ashgate Pub. Co., 1996), p. 93, emphasis retained. 
draw on affective forces incompletely and without mirroring their focus. Massumi, in 'The Autonomy of Affect', makes the distinction between affective forces (intensities) and emotions clear: '[e]motion is qualified intensity, the conventional, consensual point of insertion of intensity into semantically and semiotically formed progressions, into narrativizable action-reaction circuits, into function and meaning. It is intensity owned and recognized' (p. 88). As bodily affective forces are translated into emotions they are not only narrowed but can be twisted or redirected. Freud suggests the same relationship between preconscious forces and emotions when he posits psychological mediations like reaction-formation. In Three Essays on a Theory of Sexuality (1905), Freud speculates that, faced with an onslaught of inexpressible sexual desire, the ego may defend itself by turning on this desire, creating a strong public and conscious show of aversion to the very real wish. The stronger the embodied affective force the more inflexible and severe the outward aversion appears and the more the reaction-formation becomes intertwined within the personality of the Subject. ${ }^{35}$

Freud warns, however, that although powerful, the reaction-formation is always 'insecure and constantly threatened by the impulse which lurks in the unconscious' (p. 533). If EBB's stance is akin to Freud's concept of reactionformation, the reader should be able to find her unconscious sexual desires bubbling up, bursting through the text. In fact, even a rather casual read of Aurora Leigh seems to quickly reveal just that. For example,

There were words

That broke in utterance ... melted, in the fire -

Embrace, that was convulsion ... then a kiss

As long and silent as the ecstatic night,

And deep, deep, shuddering breaths, which meant beyond

Whatever could be told by word or kiss. (IX: 719-24)

The moment is clearly one of erotic release, although it might be noted that Romney had to be stricken blind, like Oedipus, before it becomes possible. Or, consider the description of Marian's heart as she escapes her first sexual encounter (and yet seems not to):

While her heart

Kept swelling, swelling, till it swelled so big

It seemed to fill her body - when it burst

${ }_{35}$ Robert Jean Campbell, Psychiatric Dictionary, $6^{\text {th }}$ edn. (New York: Oxford University Press, 1989), 533-4; Jean Laplanche and J. B. Pontalis, The Language of Psycho-Analysis (New York: Norton, 1974), pp. 376-8. 
And overflowed the world and swamped the light;

'And now I am dead and safe,' thought Marian Erle.

(III: 1084-8)

Beyond the 'swelling' erotics and ejaculatory 'burst[ing]', there is also the traditional interplay of death and orgasm in these lines. Then, we might also recall EBB's adoption of the voyeur's gaze, especially as it is directed towards women, as it is, for example, in this image of Lady Waldemar:

The woman looked immortal. How they told, These alabaster shoulders and bare breasts,

Of which the pearls, drowned out of sight in milk,

Were lost, excepting for the ruby-clasp!

They split the amaranth velvet bodice down

To the waist or nearly, with audacious press

Of full breathed beauty. (V: 618-24)

Although these lines are made heteronormative by being placed in the mouth of a man, they issue, of course, from EBB. In passages like these, or in Aurora's Sapphic proposal to Marian ('I've a home for you / And me and no one else' (VI: 458-9)), lie glimpses of EBB's queer desires.

My aim, however, is not to spot erotics; it is to suggest why they appear. For EBB, it seems that 'Fourier', in addition to marking the abuses of patriarchy, the waste of naïve politics, and a credible threat to the bourgeois nuclear family, had also come to signify her own erotic desires - affective forces with which she could not consciously come to terms. Throughout EBB's life there is a pattern of sexual desire linked with crippling repression: a secret delight in erotic fiction that also filled her with shame (Dally, p. 81); a jealous attachment to the blind and married scholar, Hugh Boyd, who was twenty-six years her senior $;{ }^{36}$ a child-like dependence on her father that lasted late into her thirties; ${ }^{37}$ an imagined commitment to her deceased brother that nearly prevented her marrying Robert Browning (p. 34). There is even evidence that she went so far as to keep her sexuality at bay through anorexia, which diminished her libido and stopped her menstruation (Dally, p. 83). I am arguing that EBB's cautious reformism, her multifaceted construction of 'Fourier' in Aurora Leigh,

${ }^{36}$ Dally, pp. 41-2; Forster, p. 59; for a more complete account of EBB's troubled relationship with Boyd and the possible connections between Hugh Boyd and blind Romney see Julie Miele Rodas, 'Misappropriations: Hugh Stuart Boyd and the Blindness of Elizabeth Barrett Browning', Victorian Review. 33: 2 (Fall 2007), pp. 103-118.

${ }^{37}$ Isabel Constance Clarke, Elizabeth Barrett Browning: A Portrait (London: Hutchinson \& co., 1929), pp. 53-4. 
and her rejection of free love socialism, are also strategies for coping with layers of guilt and shame.

We should be mindful that Romney's radicalism is shameful, too - always a kind of illicit affair, the guilty obsession of a man who should be happier at home. In him we see that 'Fourier', with its contradictory shades, stands for the impossibility of desire, whether economic or erotic. Beneath 'Fourier', these unlikely complements join to achieve a political depth for Aurora Leigh, but, in tracing back their origins, they also indicate something of the complex process by which Subjects come to commit themselves to ideological positions and how texts emerge through the interactions of various affective forces, from both outside and inside, including those of politics, family, and sexuality. They suggest how the discourses surrounding the capitalist economy (which claims to be a social organization without credible alternatives) and those of bourgeois sexuality (which denies, as intolerably perverse, all desires beyond the narrow limits of heteronormative coupling) mutually reinforce one another, that what the ideology of liberalism seeks to conserve through reform is not only the dominant socio-economic order but also the myth of the unified, normative self. In short, although EBB might have been drawn to the plurality of Charles Fourier's free love socialism, the open expression of those burning passions were not choked by socialism's singular vision, as EBB claimed, but by the unyielding social and economic absolutism of liberal reform.

\section{Bibliography}

Ahmed, Sara. 'Happy Objects'. The Affect Theory Reader, ed. Melissa Gregg and Gregory J. Seigworth. Durham: Duke University Press, 2010.

Avery, Simon. 'The Voice of the Decade: Elizabeth Barrett's Political Writings of the 1840s'. Elizabeth Barrett Browning, ed. Simon Avery and Rebecca Stott. New York: Longman, 2003.

—. 'Telling It Slant: Promethean, Whig, and Dissenting Politics in Elizabeth Barrett's Poetry of the 1830s'. Victorian Poetry 44: 4, 2006.

Barthes, Roland. Sade, Fourier, Loyola. New York: Hill and Wang, 1976.

Beecher, Jonathan. Charles Fourier: The Visionary and His World. Berkeley: University of California Press, 1986.

Browning, Elizabeth Barrett. Aurora Leigh, ed. Kerry McSweeney. New York: Oxford University Press, 1993.

-. Diary by E. B. B.; the Unpublished Diary of Elizabeth Barrett Barrett, 1831-1832, ed. Philip Kelley and Ronald Hudson. Athens: Ohio University Press, 1969.

-. Elizabeth Barrett Browning: Letters to Her Sister, 1846-1859, ed. Leonard Huxley. London: J. Murray, 1929. 
-. The Letters of Elizabeth Barrett Browning to Mary Russell Mitford, 1836-1854, ed. Mary Russell Mitford, Meredith B. Raymond, and Mary Rose Sullivan, 3 vols. Waco, Texas: Armstrong Browning Library of Baylor University, 1983. Browning, Elizabeth Barrett and Frederic G. Kenyon, The Letters of Elizabeth Barrett Browning. 2 vols. New York: The Macmillan Company, 1899.

Browning, Robert and Elizabeth Barrett Browning, The Brownings' Correspondence, ed. Philip Kelley and Ronald Hudson. Winfield, KS: Wedgestone Press, 1984.

Campbell, Robert Jean. Psychiatric Dictionary, $6^{\text {th }}$ edn. New York: Oxford University Press, 1989.

Clarke, Isabel Constance. Elizabeth Barrett Browning: A Portrait. London: Hutchinson \& Co., 1929.

Dalley, Lana L. 'The Least "Angelical” Poem in the Language: Political Economy, Gender, and the Heritage of Aurora Leigh'. Victorian Poetry 44: 4, 2006.

Dally, Peter. Elizabeth Barrett Browning: A Psychological Portrait. London: Macmillan London, 1989.

David, Deirdre. Intellectual Women and Victorian Patriarchy. London: Cornell University Press, 1987.

'The Free Love System'. New York Daily Times, 8 September 1855.

Forster, Margaret. Elizabeth Barrett Browning: A Biography. London: Chatto \& Windus, 1988.

Fourier, Charles. The Utopian Vision of Charles Fourier; Selected Texts on Work, Love, and Passionate Attraction, ed. Jonathan Beecher and Richard Bienvenu. Boston: Beacon Press, 1971.

Guarneri, Carl. The Utopian Alternative: Fourierism in Nineteenth-Century America. Ithaca, N.Y.: Cornell University Press, 1991.

Kaplan, Cora. 'Introduction', Critical Essays on Elizabeth Barrett Browning, ed. Sandra Donaldson. New York: G. K. Hall, 1999.

Kessous, Naaman. Two French Precursors of Marxism: Rousseau and Fourier. Brookfield, Vt.: Ashgate Pub. Co., 1996.

Laplanche, Jean and J. B. Pontalis. The Language of Psycho-Analysis. New York: Norton, 1974.

'Letters from England, No. 6: The Refugee - Louis Blanc'. New York Daily Times, 4 October 1854.

Levin, Michael. 'John Stuart Mill: A Liberal Looks at Utopian Socialism in the Years of the Revolution 1848-49'. Utopian Studies. 14: 2, 2003.

Lewis, Linda M. Elizabeth Barrett Browning's Spiritual Progress: Face to Face with God. Columbia: University of Missouri Press, 1998.

Loman, Andrew 'Somewhat on the Community-System': Fourierism in the Works of Nathaniel Hawthorne. New York: Routledge, 2005.

Massumi, Brian. 'The Autonomy of Affect'. Cultural Critique 31, Autumn 1995. Massumi, Brian and Mary Zournazi. 'Navigating Movements' (interview). Hope: New Philosophies for Change, ed. Mary Zournazi. New York: Routledge 2003. Patterson, Ian and Gareth Stedman Jones. 'Introduction', in Fourier, Charles. The Theory of the Four Movements. Cambridge: Cambridge University Press, 1996. 
Rodas, Julie Miele. 'Misappropriations: Hugh Stuart Boyd and the Blindness of Elizabeth Barrett Browning'. Victorian Review. 33: 2, Fall 2007.

Stewart, Kathleen. 'Worlding Refrains' (afterword), The Affect Theory Reader, ed. Melissa Gregg and Gregory J. Seigworth. Durham: Duke University Press, 2010.

Stott, Rebecca. 'How Do I Love Thee?: Love and Marriage'. Elizabeth Barrett Browning, ed. Simon Avery and Rebecca Stott. New York: Longman, 2003.

Thomson, Patricia. George Sand and the Victorians: Her Influence and Reputation in Nineteenth-Century England. London: Macmillan, 1977.

Williams, Raymond. Marxism and Literature. Oxford: Oxford University Press, 1977.

Wallerstein, Emanuel. The Modern World-System IV: Centrist Liberalism Triumphant, 1789-1914. Berkeley: California University Press, 2011. 


\section{Afterword}

While the individual essays in this collection each examine a particular aspect of women's literary networks during the Romantic period, when taken as a whole, larger patterns begin to emerge and invite further exploration. Broadly speaking, these patterns might be organized according to five tentative claims: (1) networks led to a densely interconnected Romantic world; (2) manuscript letters and life writing were vital parts of literary networks and deserve re-examination as literature; (3) men were an important part of women's literary networks, but not necessarily in all the ways we have come to expect; (4) women used networks to become active in political, social, and religious causes and debates from which they were otherwise excluded; and (5) women's networks were intergenerational and trouble easy distinctions between literary periods.

\section{An Interconnected Romantic World}

The essays in this volume suggest that the era's fundamental alterations to the means and conditions of mediation not only made Romanticism possible, but drew in groups and writers often excluded from traditional accounts of the period. As has been well-documented elsewhere, the eighteenth-century world was a place of expanding social networks, buoyed by structural transformations in how information was produced, mediated, and circulated. Beginning with Habermas's foundational study of how print and periodical culture altered bourgeois public space at the beginning of the eighteenth century, a generation of scholars has productively explored, expanded, and challenged Habermas's work, producing a rich body of scholarship that illustrates the extent to which the eighteenth-century world was interconnected. More recently, Siskin and Warner have offered an important addition to this body of scholarship in 


\section{Afterword}

This is Enlightenment, arguing that transformations to the means of mediation themselves - what they term 'cardinal mediations' (the post-office, turnpike, associational practices, coffee houses, etc.) - help to explain some of the larger social, political, philosophical, and literary projects that we have come to think of as the 'Enlightenment'. 'What has been less well documented or considered is how these fundamental shifts in the conditions of mediation played out during the Romantic period, and what these changes meant for how Romantic-era writers thought about themselves, their relationships with one another, and their relationship to a rapidly-expanding public space.

Amidst this shift in the conditions of mediation, both women and men not traditionally considered 'writers' in the literary sense were often a vital part of Romantic-era networks, lending emotional, spiritual, and even financial support in addition to addressing more 'literary' matters. Henrietta Fordyce, for example, wife of Reverend James Fordyce, corresponded with Sally Wesley as a friend and on religious subjects, but also with publishing house Cadell \& Davies about the business of her deceased husband's publications. The relatively unknown 'bluestocking' Marianne Thornton, daughter of Clapham abolitionist Henry Thornton, would have been known to Elizabeth Heyrick's and Susanna Watt's network in the Midlands, but she also corresponded with Sally Wesley about financial matters, as Thornton's father subscribed $£ 10$ a year for the maintenance of Sally and her mother Sarah during a particularly difficult time following the death of Charles Wesley. The variety of women just in Wesley's lesser-known network reminds us that the sheer number of writers, male and female, who participated in the literary marketplace and literary conversations expanded exponentially in the Romantic era. At the same time, access to this marketplace (even for writers at the 'margins' in Ireland or provincial England) and to the marketplace of ideas inculcated in letters and polite conversation was quicker and more expedient than during any previous literary era. Even if individual writers did not know one another, the proliferation of print texts made it easier than ever before for women to respond to other authors through 'networks of citation' of the type Linkin considers in Chapter Seven.

The depth and breadth of the connections fostered by women in Romanticera literary networks thus indicates just how little we still know about the nature of the interconnected Romantic world. For one thing, the networks traced in this volume of essays ask us to rethink what it meant to be 'marginal' in this period: to what extent do our standard accounts of the literary margins persist, and to what extent must they be revised? These kinds

${ }^{1}$ Clifford Siskin and William Warner, 'This is Enlightenment: An Invitation in the Form of an Argument', in This is Enlightenment, ed. Clifford Siskin and William Warner (Chicago: University of Chicago Press, 2010), pp. 1-33, (p. 1). 
of questions have significant implications for how we think about literary production and the role of the individual author. Not only was Romantic-era work not produced in isolation, it was produced in conversation with many other voices - a conversation that was made possible by increased letter and manuscript circulation.

\section{Letters and Manuscript Circulation}

As we continue to reassess the canon of Romantic literature, heightened attention to the letter as a literary genre can help us dislodge the gendered hierarchies that prevent us from seeing the Romantic world in all its nuance and complexity. The essays in this collection suggest that reading the letter as literature - rather than as ancillary material whose primary purpose is to contextualize some other more 'important' text - opens up new ways of thinking about how texts and audiences were constructed during the Romantic period, what types of writers and readers had access to different forms of literary production, and how letters and other types of manuscript texts were intended to be read and circulated. Letters and manuscripts were not only the primary means through which literary networks formed and were sustained, they provided a discourse structure which women could and did adapt when they made the move to print. As Levy points out, during this time period, 'many works that began in more private or sociable contexts rapidly migrated to more social and public media, ${ }^{2}$ Letter-writing in particular came to occupy what Clare Brant has described as a 'personal' space, as opposed to a fully public or private one. ${ }^{3}$ This idea of the 'personal' space of the letter is useful in that it recognizes letters as fundamentally social texts, produced and circulated in community. It also highlights the productive liminality of letters - neither wholly 'this' nor 'that' - and therefore their status as a genre ripe for experimentation and innovation.

Recognizing letters and manuscripts as innovative literary texts thus troubles many of the (often gendered) assumptions we have come to rely on about what constitutes a text - or, for that matter, an author - worthy of critical attention. Scholars of women's writing have been arguing for the importance of letters as literature for at least a decade (in part due to necessity), and scholars who study more canonical male authors have also begun to demonstrate the fruitfulness of reading letters in this light. At a 2017 Modern Language Association panel on

2 Michelle Levy, 'Women and Print Culture, 1750-1830', in The History of British Women's Writing, 1750-1830, ed. Jacqueline Labbe (Basingstoke: Palgrave Macmillan, 2010), pp. 29-46, (p. 34).

${ }_{3}$ Clare Brant, Eighteenth-Century Letters and British Culture (New York: Palgrave Macmillan, 2006), p. 5. 
'Re-Loading the Romantic Canon', for example, Pamela Clemit and Michael Rossington argued for the importance of better understanding how letters functioned in the Godwin-Shelley circle. In particular, Clemit argued that the form of the letter itself, in its expression of social 'regard', could be read as explicitly literary. ${ }^{4}$ Continued study of how women used letters, and the rhetorical and authorial possibilities letters provided them, helps us challenge the all-too-common assumption that letters by men like Godwin or Percy Shelley are inherently more 'literary' than those by their female counterparts.

More work is needed, then, not only on how letters circulated and formed literary networks, but also on the form of the letter itself within the context of manuscript exchange. Runia's essay in this volume (Chapter Eight), for example, usefully explores how Maria Edgeworth's Letters to Literary Ladies internalizes the conventions of eighteenth-century letter writing; when we forget how letters operated and the functions that they performed for contemporary readers and writers, Edgeworth's text loses legibility. As Brant usefully reminds us, 'many women writers in eighteenth-century Britain were not novelists, poets, or dramatists. They were writers of letters, diaries, memoirs, essays - genres of sometimes uncertain status then and certainly liminal status now'. We might then ask: how did women exploit the uncertainty of the genre? How might the letter's liminality connect to women's construction of authorial identity? How did the letter's generic conventions influence the wider Romantic-era literary culture? These questions will help us re-examine not only the ways in which women formed and sustained connections with one another, but with men as well.

\section{Men's Roles in Women's Networks}

While men were an important part of women's literary networks - as editors, publishers, mentors, and means of financial support - the essays in this collection indicate that theirs was not always the authoritative position we might have come to expect. As Beshero-Bondar and Donovan-Condron point out in Chapter Six, for example, the networks surrounding Mary Russell Mitford show the author performing a wide variety of roles in relation to the men in her network over the course of her long life. While she, like many of the Cadell \& Davies authors discussed in Chapter Five, may have relied on powerful men to ease her entry into public space early on, by the time she

${ }^{4}$ Pamela Clemit, 'The Signal of Regard: William Godwin's Correspondence Networks', Reloading the Romantic Canon: New Texts and Contexts from Godwin, Shelley, and Hazlitt, Modern Language Association Convention, Philadelphia, PA, 5 January 2017.

5 Clare Brant, 'Varieties of Women's Writing', in Women and Literature in Britain 1700-1800, ed. Vivien Jones (Cambridge University Press, 2000), pp. 285-305 (p. 285). 
was older it was she herself who occupied a central network node; she became someone whom others - women and men - approached in order to advance their careers. Furthermore, what we may tend to see as primarily commercial and hierarchical interactions, such as those between authors and publishers, also have important (and more nuanced) social dimensions. While Cadell \& Davies was undoubtedly a business, in Chapter Five Levy and Irwin convincingly argue that the publishing firm's relationship with its female clients was more than that: it was also a social relationship that helped foster the entry of numerous women into the marketplace of print.

Rethinking the scope and the gendered nature of 'influence' in the Romantic period - 'influence' as textual as well as lived interaction - thus destabilizes longstanding gender binaries. Nesvet, for example, argues in Chapter Nine that Mary Shelley was consciously influenced by and responding to the Marquis de Sade despite the sexually-taboo nature of his work. Shelley's place in Sade's global network of literary influence, which Nesvet shows is generally constructed as exclusively male, reveals that the cultural ideas about female propriety that might have shaped literary reception in this period were not the barriers to literary production that we might assume. More broadly, Chapters Eight to Ten of this volume illustrate the need for a more complex exploration of how networks of influence shaped sexuality and female authorial identity, particularly those involving women writers and controversial male figures such as Sade, Thomas Day, and Charles Fourier. Along with interrogating our own assumptions about literary influence in this period - as twenty-first-century scholars have at times tended to replicate the Romantic-era 'gentlemen's club' - we might also ask: how did women signal or disavow different forms of 'influence' in their work? Re-examining the ways in which women writers influenced and were influenced by their male peers might also help us see more clearly the innovative possibilities presented by single-sex networks.

\section{Women's Networks and Public Space}

Though women sometimes relied on men for access to public space, the essays in this volume reveal that single-sex networks often provided women with creative points of entry into conversations about the major social, political, and religious questions of their day. Moreover, these single-sex networks allowed them to act outside social boundaries. Consider, for example, the abolitionist work of Elizabeth Heyrick and Susanna Watts in the Midlands, which James and Shuttleworth detail in Chapter Three. While Heyrick and Watts were connected to the main body of the abolitionist movement led by men like William Wilberforce and Henry Thornton, their publications and local abolitionist activities often diverged from what these male leaders thought was 
appropriate. By advocating for immediate emancipation, going door to door campaigning for abolition, and even by sewing abolitionist tracts into work bags, these women challenged cultural assumptions about the proper roles for women within public space. ${ }^{6}$

Single-sex networks also allowed women to participate in conversations from which they were almost entirely excluded otherwise. For example, the women in Sally Wesley's network, examined in Chapter Two, were deeply invested in the major theological and religious debates of the period. Long before Percy Shelley was expelled from Oxford for publishing The Necessity of Atheism, the Methodist Sally Wesley was on friendly terms and corresponding regularly with the avowed atheist Rachel Lee. While atheism itself was still unspeakable in public space, women in this network were nonetheless comfortable discussing taboo theological questions without rancor using the semi-public space of the letter. Sally Wesley even went so far as to invite Lee to visit with Thomas de Quincey's family while she was governess to his younger sister - an invitation that eventually resulted in her dismissal from her position. ${ }^{7}$ Thus, while women were increasingly excluded from public conversations, their networks illustrate the creative ways that they circumvented these cultural restrictions. To better understand this social and political practice, we might ask: what various forms did single-sex networks take? How might these forms have been shaped by the issues with which women engaged? To what degree did single-sex networks cohere to or deviate from the protocols of networks that included women and men? These questions might also help us better understand the ways in which women from different generations formed bonds with one another.

\section{Intergenerational Networks and Periodization}

The essays in this volume suggest that the idea of literary periodization is inherently limiting, given how writers spoke and related to each other across generations, with older writers shaping their own reputations and legacies while mentoring and influencing younger writers. Culley's and Linkin's essays (Chapters Four and Seven, respectively), for example, illustrate how female writers molded their literary reputations into old age and built these reputations through what Linkin deems 'citational networks'. In addition, Beshero-Bondar and Donovan-Condron (Chapter Six) give a bird's-eye view of how the literary reputation of Mary Russell Mitford was formed over her

\footnotetext{
${ }^{6}$ See Linda Colley, Britons: Forging the Nation, 1707-1837 (New Haven: Yale University Press, 1992).

${ }^{7}$ For De Quincey's account of Lee and this episode see Chapter Five, 'The Female Infidel', of The Collected Writings of Thomas De Quincey, Volume I (London: A\&C Black, 1896), pp. 134-48.
} 
lifetime in conversation with multiple generations. Such intergenerational links often cross the boundaries drawn by literary scholars. Mitford, for example, mentored the young Elizabeth Barrett Browning, who is the subject of Hood's essay (Chapter Ten) on Aurora Leigh. While Barrett Browning is not traditionally considered a Romantic poet, she was in correspondence with and clearly influenced by writers firmly ensconced in Romanticism and in fact only barely outlived Joanna Baillie, Mary Berry, and Mitford herself. These links should lead us to ask: how or why is an author defined as 'Romantic'? How might labels such as 'Romantic' occlude other - perhaps more important - connections? Scholarly attention to networks, we propose, is one important way of approaching these questions with renewed vigor.

\section{Conclusion}

As a final note, working on this volume was itself a collaboration within a scholarly network, and as such, we intentionally strove to open up new avenues and possibilities for scholarly work and publication. The network that produced this volume is diverse and includes scholars on both sides of the Atlantic and at different points in their academic careers. Some of us are distinguished scholars with long careers and publication records behind us, some are tenured or on the tenure track, while others labor in the new scholarly economy of full time, non-tenurable positions. Others of us are graduate students, just beginning our academic careers, invited into the project by more senior scholars. In each case, however, what we found working on this volume was that the models of collaboration and sociability that women used during the eighteenth century are still very much alive today and provide exciting and alternative models of scholarly production. This project began as a collaboration between Andrew Winckles and Angela Rehbein in 2013; it has now become two projects, and along the way we have been privileged to welcome some of the kindest and most generous scholars we have ever known into our network. ${ }^{8}$ At a time when the scholarly monograph is still king, and those of us who are privileged enough to obtain funding to travel to archives jealously guard our information, it has been refreshing to work together with these men and women to produce something larger than the sum of its parts.

We also found that writing about networks, trying to describe their contours and reach, is difficult work by its very nature. Networks during the Romantic period were diverse and wide-ranging; even a small sample of many of these women's networks yielded such a wealth of information that it became difficult to analyze concisely or to organize findings around a central idea or argument.

${ }^{8}$ See Rehbein and Winckles, eds., 'Reassessing British Women Writers of the Romantic Period', in Women's Writing 22.2 (2015). 
These women's lives were rich and diverse and even the limited scope of this book illustrates just how much we still do not know about their lives and work. Perhaps that, however, is the greatest contribution of this volume. Our hope is that the lines of inquiry we open up here will bring even more people into our scholarly network and that the work we have begun will represent just the beginning of scholarly inquiry into this unruly 'tribe of authoresses'.

\section{Bibliography}

Brant, Clare. Eighteenth-Century Letters and British Culture. New York: Palgrave Macmillan, 2006.

-. 'Varieties of Women's Writing'. Women and Literature in Britain 1700-1800, ed. Vivien Jones. Cambridge University Press, 2000.

Clemit, Pamela. 'The Signal of Regard: William Godwin's Correspondence Networks', Reloading the Romantic Canon: New Texts and Contexts from Godwin, Shelley, and Hazlitt. Modern Language Association Convention, Philadelphia, PA, 5 January 2017.

Colley, Linda. Britons: Forging the Nation, 1707-1837. New Haven: Yale University Press, 1992.

Levy, Michelle. 'Women and Print Culture, 1750-1830'. The History of British Women's Writing, 1750-1830, ed. Jacqueline Labbe. Basingstoke: Palgrave Macmillan, 2010.

De Quincey, Thomas. The Collected Writings of Thomas De Quincey, Volume I. London: A\&C Black, 1896.

Rehbein, Angela and Andrew O. Winckles. 'Reassessing British Women Writers of the Romantic Period'. Women's Writing 22.2 (2015).

Siskin, Clifford and William Warner. 'This is Enlightenment: An Invitation in the Form of an Argument'. This is Enlightenment, ed. Clifford Siskin and William Warner. Chicago: University of Chicago Press, 2010. 



\section{Index}

abolition 5, 7, 11, 48-70, 299, $302-3$

Ackerman, Rudolph 166

An Address on the State of Slavery in the West India Islands 55-6

affect 12-13, 274-5, 293-5

affective network 276

ageing 73-5, 76, 81-2, 88, 90

Aikin, John 64

Aikin, Lucy 23, 30, 53, 81, 93-4

'Recollections of Joanna Baillie' 81, 93-4

Anglicanism 19-20, 42, 50, 56, 67 animal rights $50-1,54$

anonymity $2,5,18,22,43,76 \mathrm{n} 13$, 76n14, 77, 86, 95, 113, 119-20, 207, 215

Apollinaire, Guillaume 249, 254

Asgill, Lady 213-14

Asgill, Sir Charles 213

atheism 42, 245, 259, 260, 303

Austen, Jane 20, 91, 132, 138-9,

$141,146,159,166,189,269$

authorial formation 8-9

author-publisher relationship 12, 29n22, 74, 80, 99-132, 147, $162,166,169,175,182,259$, $301-2$ autobiography 84-7

auto-canonization 217, 219

Babington, Thomas 55-6

Baillie, Agnes 75

Baillie, Joanna 11, 19, 73-96, $117-19,122,124,138-9,148$, 220, 304

'Memoirs Written to please my Nephew William Baillie' 83-5

Metrical Legends 79, 87

Plays on the Passions 77, 85-6

'Recollections Written at the Request of Miss Berry' 83-4

$A$ View of the General Tenour of the New Testament 80

Baillie, Matthew 75, 86

Bannerman, Anne 204

Baptists 63, 67-8

Barbauld, Anna Letitia 4, 12, 22-3, 30-2, 64, 66, 75, 81, 90, 197-8, 206-7, 211, 220, 258

Barrett, Charlotte 23

Barthes, Roland 282

Barwell, Louisa 23

Bataille, Pierre 250, 254

Bates, Elizabeth 23

Beale, Catherine Hutton 63, 70 
Women's Literary Networks and Romanticism

Benger, Elizabeth 2-3, 5-6, 16, 23

Bennett, William Cox 143, 174

Bentley, Elizabeth 54

Bentley, Richard 87, 167

Bentley, Samuel 167

Benyon, Richard 165

Bere, Thomas 123

Berry, Agnes 75, 84

Berry, Mary 5, 11, 73-96, 304

Social Life in England and France $73,80,83,89$

Birkbeck, Morris 180-1, 183

Birmingham Female Anti-Slavery

Society 58-60

Blachford, Theodosia 22-3

Blackstone, William 99

Blagdon Controversy 30, 123

Blair, Anne Persode 127, 130

Blair, John 130

Blanc, Louis 274, 285

Blanchot, Maurice 250, 252-4

Bluestockings 4, 7, 17-18, 21, 42,

75, 299

Bonaparte, Napoleon 170

book sales 113, 114, 118, 124-7,

$$
\text { 129-30 }
$$

Boswell, James 123

Bowdler, Henrietta Maria 103, 127

boycotts 49, 56, 58, 60, 68

Boyd, Hugh 294

Breton, Andre 252

British Empire 4, 139

Brooke, Frances 106, 122

Browning, Elizabeth Barrett 10, 13, 142-3, 146, 152, 154, 169-70, 174, 220, 274-95, 304

Aurora Leigh 274-95

Browning, Robert 280-1, 289-91, 294

Brunton, Mary 220

Bulmer, Agnes 5, 23, 42

Burney, Charles 5, 230

Burney, Frances 5, 12, 17, 90, 99
Burns, Robert 99

Byron, George Gordon 139, 141, 143, 159, 164, 173, 181, 184, 189, 246, 257, 269

Byron, Lady Annabella 248

Cadell and Davies 11-12, 99-132, 299, 301-2

Cadell, Thomas Sr. 99, 111, 125-7, 131

Cadell, Thomas Jr. 100

Cannon, George 259

canvassing 49, 56, 58-60, 303

capitalism 275-7, 282, 283, 295

Carlile, Richard 259

Carlyle, Thomas 277, 280

Carter, Angela 254-5, 270

Carter, Elizabeth 17

Catholicism 42, 209

Charleville, Lady 214

Child, Lydia Maria 48

Chorley, Henry 146

citational network 12, 183-4, 191, 192, 197-221, 299, 303

Clairmont, Jane 245, 258, 261, 268-9

Clapham Sect 56, 299

Clarkson, Thomas 65

Clowes, John 29

Cobb, James 260

co-citation see citational network

Colburn, Henry 169

collaboration 7, 9, 47-70, 73-4, $77-8,83,87,96,145-50,164$, 259, 304

Coleridge, Hartley 91

Coleridge, Samuel Taylor 1-2, 19, 22, 29, 43, 85, 159, 181, 183, 189, 203

Colman, George Jr. 166, 169

Coltman, Elizabeth 50, 63, 65

Coltman, John 55, 63-4

Coltman, John Jr. 64

Coltman, Mary Ann 47, 63, 67-8 
Coltman, Samuel 63, 70

Time's Stepping Stones 63, 65

communism 278, 281-2, 285

Considerant, Victor 274, 283

conversation 8, 9, 11, 22, 41-9, 54,

78-9, 81, 84, 92, 160, 198, 200,

299-300, 302-4

Cooper, Alicia 67

copyright 29n22, 107, 112, 114,

$114 \mathrm{n} 29,117-19,122,127,130$,

143,226

correspondence $1-4,6,9,12,13$,

19, 21-2, 23-5, 27-32, 48, 56,

73, 74, 77-96, 99-132, 139,

142-4, 146-7, 151-93, 280-1,

285, 289, 290, 299-301, 303

Cosway, Maria 23

coterie 4, 8, 16, 48, 198, 258, 267, 269

Cowley, Hannah 12, 99, 106, 122, 129

Crosland, Margaret 254

Currie, James 116

Dacre, Charlotte 256-7, 267,

$$
\text { 269-70 }
$$

Darwin, Erasmus 10

Davenport, Richard Alfred 157

Davies, William 100

Day, Thomas 13, 226-7, 229-35,

237-8, 240, 302

The History of Sandford and

Merton 231-2, 234-5

De Beauvoir, Simone 251-4, 267, 269

Declos, Anne 252-4, 270

L'histoire d'O 252

De Crébillon, Claude-Prosper Jolyot 258

De Crespigny, Mary Champion 124

De L’Age, Comte 24

De La Main, E. 24

De Quincey, Elizabeth 24

De Quincey, Thomas 24, 303
De Staël, Germaine 198-9, 202, 204, 206, 216, 220, 257, 260

Corinne 198-9, 202-4, 216, 257

Dickens, Charles 143

Dickinson, Emily 220

Digital Mitford 12, 139-41, 145-7, 149-51, 162, 182

dissent 7, 50, 53, 63-9

Dobson, Susannah 125

Doddridge, Mercy 24, 27-8, 42

Dodsley, Robert 65

domesticity 56-9, 66, 85, 201, 268

domestic sphere $13,57,59,227-8$, 232, 279

'Dr. Squintum's Exaltation or the Reformation' 40

Dupont, Jacob 245

Easton, Daniel 259

Edgeworth, Maria 13, 17, 22, 75, 90, 159, 226-43, 301

Belinda 229

Letters for Literary Ladies 13, 226-43, 301

Edgeworth, Richard Lovell 226, 229-31, 238

Edwards, Jonathan 43

education see women's education

Elford, Mary Davies 160

Elford, William 141-3, 152, 156-7, 159-62, 166, 170, 175, 181, 186

Engels, Friedrich 282

enthusiasm, 21-2, 30-40, 42-4

epigraph effect 197, 202, 218

Evangelicalism 11, 18-20, 21, 30, $32,36,38,39-40,42,44$

family 7, 29, 53-4, 63, 69, 74, 84-6, 209

Fearon, Henry Bradshaw 180-3

Ferrier, Susan 220

Fields, J.T. 175

Flaubert, Gustave 249

Flaxman, John 218 
Women's Literary Networks and Romanticism

Fletcher, John 186, 189

Fletcher, Mary Bosaquet 37n36

Fordyce, Henrietta 24, 42, 124, 299

Fordyce, James 24, 124, 299

Fourier, Charles 10, 13, 250, 274-95, 302

Fox, William 68

Francis, Marianne 5, 17, 21, 24, 42

Freud, Sigmund 291, 293

friendship 1, 2, 10-12, 22, 42, $47-54,62-3,68-70,74-5,77-9$, $80-2,84,86,88,90-6,119$, $122,143,146,157,159,161,169$, 208, 211, 213, 299

Gallop, Jane 253-4, 269

Gardiner, William 62

Gatehouse, Lady A. 24

Gessner, Solomon 116-17

Gibbons, Edward 99

Gilman, Richard 254-5

Gisborne, Maria 105

Godwin, William 236, 257, 259, 301

Gorer, Geoffrey 252

Greatorex, Martha 47, 53

Greenwall, Dora 220

Gregory, Dr. George 2, 29

Gregory, Dr. John 238

Grove, Harriet 259

Gurney, Martha 68

Halhed, Nathaniel Brassey 209

Hall, Anna Maria 167

Hall, Patty 17

Hall, Robert 67

Hamilton, Catherine Jane 94

Hamilton, Elizabeth 2, 4-6, 11, 16-17, 19, 21-2, 24, 27-8, 35

Memoirs of Modern Philosophers 35-8, 42

Series of Popular Essays 28

Harness, William 147, 154, 157, 162,

$164,166,173-4$

Harrison, Henrietta 154
Hawthorne, Nathaniel 174-5

Haydon, Benjamin Robert 161-2

Hayward, Abraham 169

Hemans, Felicia 12, 43, 81, 99, 106, 139, 167, 197-8, 215-20

Records of Woman 215-16

Heyrick, Elizabeth 5-7, 11, 47-70, 299, 302

Immediate, not Gradual Abolition 48-9, 56, 58, 60

Letters on the Prompt Extinction of British Colonial Slavery 60-1

Heyrick, John 50

Heyrick, William 55

Hofland, Barbara 142, 144, 154, 159-62, 165-6, 170, 173, 183, 189

Holford, Margaret Sr. 119, 121, 129

Holford Hodson, Margaret 90, 119

Hopkins, Mary Alden 114

Horne, Richard Hengist 290

Horsley, Samuel 30

Hunter, Anne 86

Hume, David 99

Hummingbird, The 49, 53-4, 64, 68-9

Hutton, Catherine 47, 63, 65, 68

incest 260-1, 262-7, 287

intergenerational sociability 13,43 , $74,81,91-6,298,303-4$

Jameson, Anna 91

Janin, Jules 249

Jephson, Emily 144, 154, 162, 164, 166, 170, 173, 175

Jephson, Robert 144

Jerrold, Douglas 166

Jewsbury, Maria Jane 220

Johnson, Joseph 236

Johnson, Samuel 99

Keats, John 196

Kemble, Charles 164, 166, 189

Klossowski, Pierre 250, 252, 254 
Lamb, Charles 1-2, 19, 29

Lamb, Mary 1-2, 29

Landon, Letitia Elizabeth 220

Lawrence, Rose 110, 116-17, 128

Leadbetter, Mary 221

Leclerc, Madeleine 251

Le Despencer, Lady R. see Lee, Rachel Fanny Antonina

Lee, Rachel Fanny Antonina 24, 42, 303

Lefanu, Alicia 12, 197-8, 208, 210-11, 220

The Outlaw 208-11

Tales of a Tourist 211

Lefanu, Alicia Sheridan 208, 211, 215

Lefanu, Elizabeth Sheridan 208-9

Leicester Auxiliary Anti-slavery Society 55, 57

Leicestershire 47

L'Estrange, A.G.K. 146-7, 154, 156-7

letters see correspondence

Lewis, Lady Theresa 95

Lewis, Matthew 204

life writing 7, 75-6

Lindsey, Theophilus 67

Linwood, Mary 47, 64, 68

literary afterlives 74, 82, 92

Literary Fund 144, 174

Longman, Thomas 80

Louvet de Courvay, Jean-Baptiste 257-8

Lyttleton, Sir George 238

Macaulay, Thomas Babington 88, 91

Mackenzie, Henry 99

Macready, William 141, 162, 166, 186, 189

Maitland, Penelope 24

Manners, Lady Mary 24

manuscript circulation 4, 6-8, 9, 11, $18,22,26-30,43-4,55,62,73$, $78,100 \mathrm{n} 5,300-1$
Mariette, Victor 245

Martineau, Harriet 84

Marx, Karl 277

Mendip Schools 30

Methodism 22, 30-1, 35, 67

Michelson, Annette 254

Mill, John Stuart 277, 280, 285

Millar, Andrew 99

millenarian 42

Milnes, Richard Monckton 95

Mitford, George 152, 156-7, 186

Mitford, Mary 152

Mitford, Mary Russell 12, 137-92, 280, 285, 289-90, 301, 303-4

Charles I 162, 166, 169-70, 177, 183

Christina, the Maid of the South Seas 148, 156-7

Dramatic Works 177, 183-4

Foscari 162, 164, 170, 189

Julian 170, 177

Narrative Poems of the Female Character 161

Our Village 138, 141-2, 146-9, $162,165,177,183-4,189$, 192

Rienzi 162, 164, 166, 170, 177

Montagu, Elizabeth 17, 238

Montgomery, James 67

Moore, John 157

Moravianism 67

More, Hannah 4, 10, 12, 19, 25, $28,30,42,53-4,56,65,99$, 104, 106, 111, 114-16, 119-20, 122-3, 127, 129, 197-8

Christian Morals 111

Hints Towards Forming the

Character of a Young Princess 119-20, 123

Sacred Dramas 115-16

Sir Eldred of the Bower 114

Strictures on the Modern System of Female Education 56-7, 121 
Women's Literary Networks and Romanticism

More, Martha 25, 42

Morgan, Lady Sydney (Owenson) 12, 197-8, 208, 211-15, 220 The O'Briens and the O'Flahertys 211-13, 215

Mortimer, Elizabeth 25

Mortimer, Mary 25

Morton, Thomas 169

Murray, John 132

Nadeau, Maurice 252

Neri, Mary Anne 121, 124

Nightingale, Joseph 31-2 A Portraiture of Methodism 31 nonconformist 48, 64

Nutburn, Ann 111-12

obscurity 5-6

Oliphant, Margaret 84

Opie, Amelia 91, 159

Orientalism 2

Owen, Robert 289

Owenson, Sydney see Morgan, Lady Sydney

Paine, Thomas 259

Palmer, Charles Fyshe 189

Palmer, Madelina 186, 189

pamphlets 49, 59-60

Parkes, Clara 52

Paulhan, Jean 250-3

Pauvert, Jean 252-3

Peacock, Thomas Love 143, 178, 180-1, 183

Nightmare Abbey 180-3

periodization $13,74,147-8$,

$$
\text { 303-4 }
$$

Perry, Kate 91

Pilkington, Laetitia 84

Piozzi, Hester Thrale 4, 17, 25 ,

104, 111, 122-3, 125-6,

131

Anecdotes of the Late Samuel Johnson 111, 122, 125-6
Porter, Anna Maria 2, 6, 12, 17, 25, 197-208, 211, 216, 220

Ballad Romances, and Other Poems 199, 203-7

Don Sebastian 204 The Hungarian Brothers 204

Porter, Jane 2, 6, 17, 25, 199, 204, 207-8

Pratt, Samuel Jackson 156

Praz, Mario 246, 249-50

Priestley, Joseph 64, 67

Pringle, Thomas 169

Proudhon, Pierre-Joseph 274, 285

provinciality 48-9

publication network 101, 132, 178, 243

public sphere 9, 59, 77, 228

Quakerism 50, 66-7

Radcliffe, Ann 12, 99, 197-8, 204, 220

Réage, Pauline see Declos, Anne

Redding, Cyrus 169

Reid, Mary 47, 63, 67-8

religion 19-20, 48, 64

reviewers $86,89-90,92,95,114$, 120, 205-7

Richardson, Ann 23

Riollay, Margaret 105, 131

Roberts, William James 137-8, 144

Robinson, Henry Crabb 16, 19, 22, 29, 42

Robinson, Mary 19, 200

Rousseau, Jean Jacques 229-30, 253, 257

Émile 230

Roscoe, Thomas 166

Rossetti, Christina 220

Rowden, Frances 156, 189

Rowe, Elizabeth Singer 7, 17

Ruskin, John 152, 171, 175 
Sade, Marquis de 10, 13, 245-70, 302

Juliette 250, 252, 256, 259

Justine 246-8, 250, 252-3, 256-7, 259-60, 263

Les Crimes de l'amour 246, 259-60, 263

salon 9, 75, 79, 83, 88, 91, 198-9, 208, 211

Sand, George 290-1

Sartre, Jean-Paul 251

Scott, Sir Walter 79, 81, 87, 93, 141, 143, 184, 189

scrapbooks 51-2, 54, 62, 67

scribal publication see manuscript circulation

Sedgwick, Catharine Maria 169, 174

Seward, Anna 7, 10, 17, 197-8

Shakespeare, William 159, 186, 189

Sheffield Female Anti-Slavery Society 59-60

Shelley, Mary 10, 13, 245-70, 302

Frankenstein 246, 250, 261-2, 263, 268-9

History of a Six Weeks' Tour 245

Mathilda 246-7, 257, 261, 263-7, 269

Shelley, Percy Bysshe 245-6, 249,

259-61, 266, 269, 277, 301, 303

Shenstone, William 65

Sheridan, Frances 207

Sheridan, Richard Brinsley 209, 229

Shoberl, Frederic 169

single women 68, 80-1, 289

Smith, Adam 99

Smith \& Elder 169

Smith, Charlotte Mary 103

Smith, Charlotte Turner 12, 19, 99, 103-4, 106, 123, 127-9, 197-8, 220

Smollet, Tobias 99

sociability 9

socialism 274, 277-8, 280, 282-8, 295
Society of Friends see Quakers

Soulié, Frédéric 247-50

Les Mémoires du Diable 247-9

Southey, Robert 81

Spence, Elizabeth 25

Spence, Joseph 65

Spilsbury, Maria 5, 11, 22,

38-40

'John Wesley Preaching in Ireland, 1789' 38-40

Spilsbury, Rebecca 25, 38

stage see theater

Starkey, Digby 175

Storace, Stephen 260

Stothard, Thomas 117

Sweetman, Laura Sophia 208

Swinburne, Algernon 249-50, 256, 267-8

Swinburne, Martha 4, 25, 42

Talfourd, Thomas Noon 141-3, 152, 162, 166, 171, 181, 186

Thackeray, William 75, 91, 96

theater 139, 145, 164, 166, 177, 192, 260

theology 20-1, 32, 42-4

Thornton, Henry 299, 302

Thornton, Marianne 25, 42, 299

Tighe, Mary 5, 8, 12, 22, 29-30, 196-221

Psyche 8, 29-30, 196, 203-4, $210,212,216,218,220-1$

Selena 201-2

Tindale, Acton 174

Tooth, Eliza 25

Trelawney, Edward John 268

Trench, Melesina 221

Trollope, Frances Milton 169

Tuite, Eliza Dorothea 112-14, 120-1, 127, 129

Tytler, Sarah 94

Unitarianism 67

Upcott, William 103 
Women's Literary Networks and Romanticism

Victorian 43, 47, 56, 91, 93-4, 145, $147-8$

Von Haller, Albrecht 238

Waller, Thomas 28

Walpole, Horace 10, 75, 87-8, 91

Walrond, Elizabeth Hall 160

Watson, Jean L. 94

Watts, Susanna 5-7, 11, 47-70, 299, 302

The Insects in Council 51

'The Slave's Address to British Ladies' 62

Webb, Eliza 178, 181

Webb, Mary 177-8, 181

Wells, Helena 121

Wesley, Charles 2, 11, 16, 18, 32, 299

Wesley, John 11, 16, 18, 36, 38-9, 67

Wesley, Sally 2, 4-7, 11, 16-44, 299, 303

'Aurelia' 41-2

The Elopement 32-5
Wesley Sarah Gwynne 2, 299

Whigs 279-82

White, Gilbert 141

Whitelaw, Elinor 105

Wilberforce, William 55-7, 302

Williams, Helen Maria 12, 99, 106

Williams, Jane 94

Wollstonecraft, Mary 13, 19, 226-7, 235-8, 240

Vindications of the Rights of Man 236, 238

Vindications of the Rights of Woman 235-6, 238

women's education $48,57,67,84$, 227-38, 240-1, 264-5

Wood, Mary 25

Wordsworth, Dora 91

Wordsworth, Dorothy 10

Wordsworth, William 10, 19, 29, 81, 85, 138-9, 159

Wright, Doug 255, 269

Young, Charles 166 